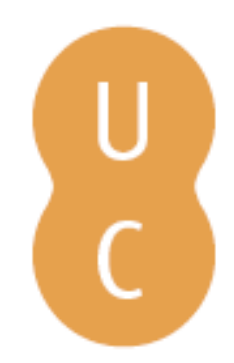

\title{
nombalina
}

\section{Génese e consolidação da ideia de Europa Vol. III: O Império Romano}

Publicado por: Imprensa da Universidade de Coimbra

URL persistente: URI:http://hdl.handle.net/10316.2/3175

DOI: $\quad$ DOI:http://dx.doi.org/10.14195/978-989-26-0394-0

Accessed : $\quad$ 26-Apr-2023 02:01:53

A navegação consulta e descarregamento dos títulos inseridos nas Bibliotecas Digitais UC Digitalis, UC Pombalina e UC Impactum, pressupõem a aceitação plena e sem reservas dos Termos e Condições de Uso destas Bibliotecas Digitais, disponíveis em https://digitalis.uc.pt/pt-pt/termos.

Conforme exposto nos referidos Termos e Condições de Uso, o descarregamento de títulos de acesso restrito requer uma licença válida de autorização devendo o utilizador aceder ao(s) documento(s) a partir de um endereço de IP da instituição detentora da supramencionada licença.

Ao utilizador é apenas permitido o descarregamento para uso pessoal, pelo que o emprego do(s) título(s) descarregado(s) para outro fim, designadamente comercial, carece de autorização do respetivo autor ou editor da obra.

Na medida em que todas as obras da UC Digitalis se encontram protegidas pelo Código do Direito de Autor e Direitos Conexos e demais legislação aplicável, toda a cópia, parcial ou total, deste documento, nos casos em que é legalmente admitida, deverá conter ou fazer-se acompanhar por este aviso.

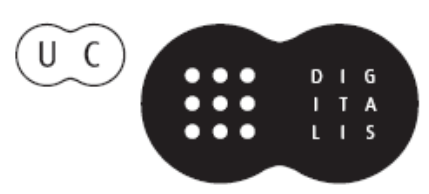


FRANCISCO DE OLIVEIRA

Coordenacào

\section{Génese e Consolidacão da Ideia de Europa}

Vol. III

0 Vundo Romano

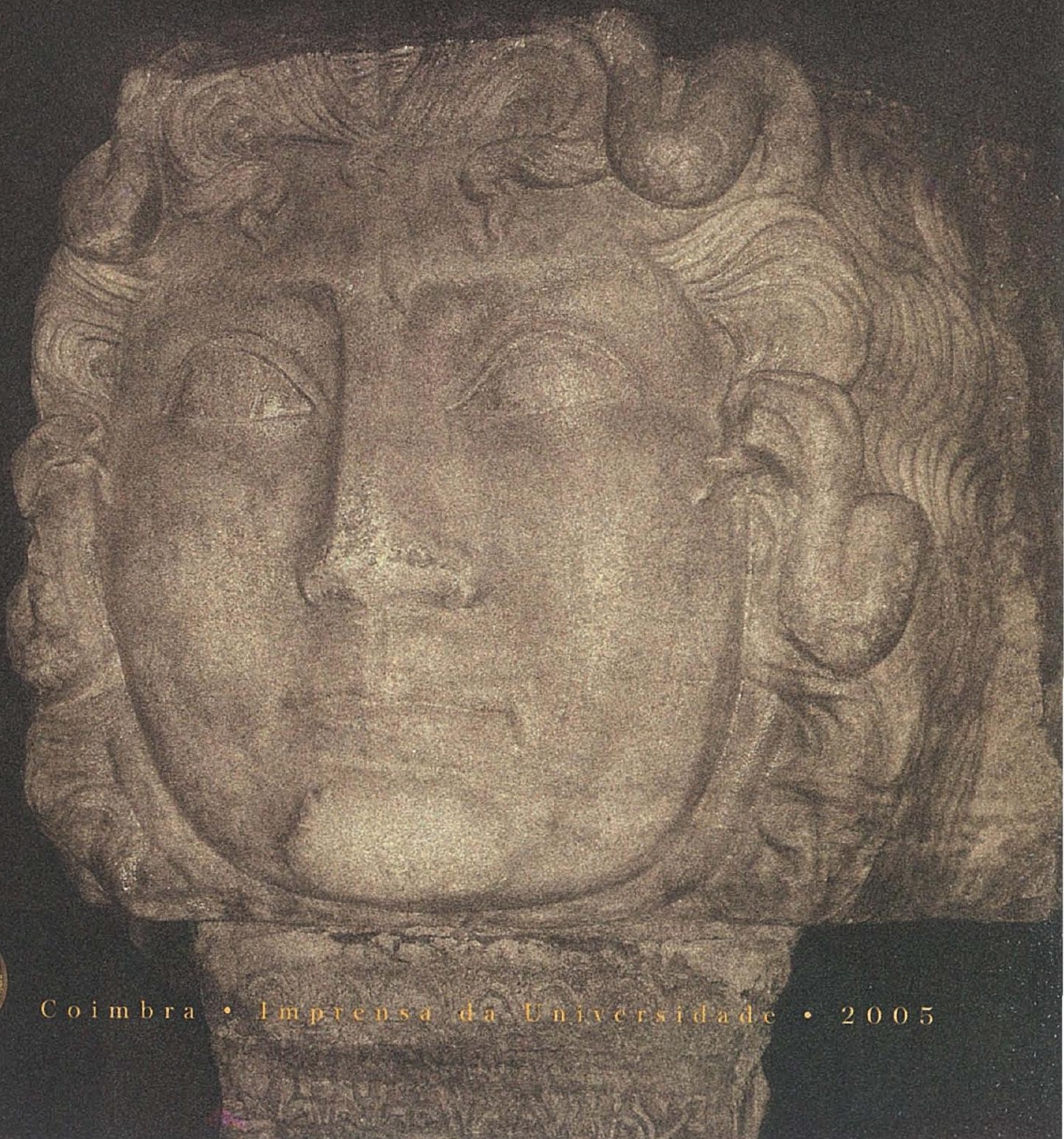


(Página deixada propositadamente em branco) 
FRANCISCO DE OLIVEIRA

Coordenação

\section{Génese e Consolidação \\ da Ideia de Europa}

Vol. III

0 Mundo Romano

Coimbra I I pronsa da Universidade 2005 


\author{
Coordenação editorial \\ Imprensa da Universidade de Coimbra

\section{Concepção gráfica} \\ António Barros

\section{Execução gráfica} \\ Imprensa de Coimbra, Lda
}

ISBN

972-8704-64-X

ISBN Digital

978-989-26-0394-0

\section{DOI}

http://dx.doi.org/10.14195/978-989-26-0394-0

\section{Depósito Legal \\ 234.088/05}

(C) Dezenbro 2005, Imprensa da Universidade de Coimbra

OBRA PUBBLICADA COM () APOIO DE:

Centro de Estudos Clássicos e Humanísticos

FCT Fundação para a Ciência e a Tecnologia

MINISTERRO DA CIRACIA E DA TECXOLOGIA

Fundação Calouste Gulbenkian

Fundação Eng. António de Almeida 
ÍNDice Geral

NOTA PRÉVIA ......................................................................................

Por Maria do Céu Fialho

UNITE ET PLURALITE CULTURELle: LE PARADIGME DE L'EMPIRE ROMAIN FACE AUX DEFIS DE L'UNION EUROPEENNE .................... 7 Por Maria Helena da Rocha Pereira

EUROPA EN EL IMAGINÁRIO DE LOS POETAS LATINOS .......................... 19

Por António Alvar Ezquerra

FUNCIÓN DE LOS EXEMPLA EN VALÉRIO MÁXIMO Y SU PERVIVENCIA EN LA EDAD MEDIA Y RENACIMIENTO ……………..................... $\quad 39$

Por Santiago López Moreda

GEONTROPOLOGIA E IMPERIALISMO EM PLÍNIO O ANTIGO .

Por Francisco de Oliveira

SUETÓNIO E O FASCÍNIO DO ORIENTE

Por José Luís Brandão

VISÕES DA ESCRAVATURA NA LITERATURA LATINA

Por Cláudia Amparo Teixeira e Paulo Sérgio Ferreira

APPUNTI SULLE VARIABILI E CONSTANTI DELL'INTERPRETATIO RELIGIOSA NELL'OCCIDENTE ROMANO .....................................

Por Giulia Baratta

IDENTIDADE E ALTERIDADE JUDAICA EM ROMA

Por Nuno Simões Rodrigues 
DACIA RIPENSIS, MOESIA SECUNDA ET SCYTHIA MINOR ENTRE LES

CULTES PAÏENS ET LE CHRISTIANISME

Por Alaxandru Barnea

AS VIAS DE COMUNICAÇÃO NA EUROPA ROMANA

169

Por Vasco Mantas

CONSTANTINO EL GRANDE: DESCONTRUCCIÓN Y CONSTRUCCIÓN DE

UN IMPÉRIO

Por Marc Mayer

LEGISLAZIONE E GIURISIIZIONE NEL DIRITTO GREGO E ROMANO ..... 231 Por Alberto Maffi

O DIREITO ROMANO E SEU CONTRIBUTO PARA A CONSTRUÇÃO DA EUROPA

Por Marleine Paula Marcondes e Ferreira de Toledo

IMAGENS DO AMOR EM SANTO AGOSTINHO

Por Arnaldo do Espírito Santo

GLOBALIZAÇÃO E REGIONALISMOS NA EUROPA ROMANA 269

Por Jorge de Alarcão 


\title{
NOTA PRÉvia
}

\author{
Maria do Céu Fialho \\ (Coordenadora Científica da UI\&D - Centro de Estudos Clássicos e Humanísticos \\ da Universidade de Coimbra)
}

\begin{abstract}
A UI\&D - Centro de Estudos Clássicos e Humanísticos da Faculdade de Letras da Universidade de Coimbra tem como tema do seu Projecto de Investigação a Génese e Consolidação da Ideia de Europa. Raízes de Identidade. Impunha-se, naturalmente, dentro deste projecto, uma investigação de equipa, em dimensão interdisciplinar, que levaria ao estudo e articulação interpretativa dos textos (entendido o termo 'texto' no seu sentido mais amplo) de natureza vária que documentam, desde os Poemas Homéricos até ao fim da Antiguidade Clássica, a presença de uma consciência de identidade-alteridade, o seu alargamento, clarificação, questionamento, desde a sua primeira identificação com o meio de comunicação - a língua grega, por oposição à incompreensibilidade de códigos comunicativos e, de seguida, de códigos comportamentais não-gregos - até à formação de uma cultura de síntese, preparada pela dinâmica intercultural da oikoumene helenística e conscientemente valorizada e sedimentada, durante o império de Roma, por Gregos e Romanos.
\end{abstract}

Há que compreender essa cultura de síntese, no contexto do Império Romano, como um elemento conglutinador que, todavia, foi capaz de deixar e respeitar o espaço de afirmação identitário às diversas províncias, numa dialéctica relacional entre o centro e as margens, suportada pela administração, pela rede viária e escolar, que contém a chave da própria romanização e da diversidade do espaço pertencente à cultura e culturas da Europa. Foi, certamente, a possibilidade de criar a consciência de pertença a uma 
imensa comunidade cultural, para além do espaço capaz de ser visualmente conhecido por cada homem ou cada grupo regional, e, ao mesmo tempo, a consciência da diversidade desse universo que lançou as bases que permitiram a Agostinho de Hipona o salto conceptual, viabilizado pelo Cristianismo. Com o filósofo neoplatónico se passou de comunidade cultural e civilizacional, dependente de uma máquina de poder instituído e coincidente com o território abarcado por esse poder, para a noção de comunidade espiritual, infractora de fronteiras sociais, étnicas e geográficas instituídas, em que cada homem é cidadão de pleno direito da Civitas Dei, de acordo com o respeito pelas leis dessa cidade.

Outra coloração adquire o binómio identidade/alteridade, no fim do Mundo Antigo, pautado, para tempos vindouros, pela distinção cristão/gentio.

A investigação de tais itinerários conduziu a uma série de três volumes (de Homero a Platão; dos oradores áticos à Cultura Helenística do período da Roma Republicana; Roma e a Cultura Helenística da época imperial).

Em um ou outro caso, a abordagem e leitura de fenómenos culturais ou interpretação de textos que, eventualmente, estejam implicados em diversos momentos desta obra conjunta, pode oferecer aspectos divergentes. Quis a equipa preservar pontuais divergências em nome da própria complexidade e possibilidade de leitura diversa do seu objecto de investigação.

Pelo seu carácter, esta investigação não podia, fatalmente, evitar algumas sobreposições de capítulo para capítulo, ainda que os seus autores o tentassem evitar, na medida do possível, através de remissões.

Em nome da equipa de Coordenadores Científicos dos três volumes e dos investigadores que neles colaboraram aqui ficam expressos os mais vivos agradecimentos, antes de mais, à Fundação para a Ciência e a Tecnologia que, através do financiamento atribuído à UI\&D, viabilizou o desenvolvimento e publicação deste estudo e o encontro, em reuniões científicas, entre especialistas convidados. De igual modo se manifesta a gratidão para com a Fundação Calouste Gulbenkian, assim como à Fundação Eng. António de Almeida, pelo apoio dado à publicação do terceiro volume.

À Imprensa da Universidade, na figura do seu distinto Director, Prof. Doutor José Francisco de Faria Costa, se dedicam as palavras de fecho desta nota prévia, a manifestar a profunda gratidão pela disponibilidade e entusiasmo, não desvinculados do rigor que pauta o seu espírito de Humanista e de Universitário, com que acolheu a publicação dos resultados deste projecto da UI\&D. 


\title{
UNITE ET PLURALITE CULTURELLE: \\ LE PARADIGME DE L'EMPIRE ROMAIN FACE AUX DEFIS \\ DE L'UNION EUROPEENNE*
}

\author{
Maria Helena da Rocha Pereira \\ (Universidade de Coimbra)
}

L'Empire Romain, le plus grand qu'ait connu l'Antiquité, a été en grande partie le produit de la conquête et d'un effort soutenu. Il a grandi et s'est conservé pendant plus de sept siècles' grâce à sa capacité d'organisation et d'assimilation des peuples qui lui étaient soumis. Le secret de l'Empire a été aussi, comme l'a vu Pierre Grimal, de "défendre, aider les cités et les hommes qui font appel à la protection de Rome et sont ainsi devenus ses alliés, ses socił".

Dans un temps où notre continent fait de remarquables efforts pour établir l'Union Européenne, moyennant l'entente, et non par la force, dans un espace géographique qui n'est pas exactement le même, mais qui lui ressemble, et par l'étendue et par la variété, il ne me semble pas inutile de réfléchir un peu sur ce phénomène. C'est ce que je vous propose.

'Ce texte reproduit, avec autorisation, l'article publié dans la revue Máthesis 13 2004. 265-275, à son tour le résultat d'une conférence donnée en français à l'Université de Cluj-Napoca (Romanie) lors du Congrès "La latinité: L'avenir d'un passé", oct. 1998. Sauf indication en contraire, les traductions françaises utilisées sont celles de la Collection des Universités de France.

' L'équipe de savants qui étudie actuellement ce sujet en copte neuf, puisqu'il place le passage de l'Empire Romain a un état médiéval en 680/1, au moment où Constantin IV reconnut le Regnum Longobardorum en Italie. Voir Leslie Webster and Michelle Brown, edd., The Transformation of the Roman World, vol. I (Leiden, 1997), p.200.

"L'Ame Romaine (Paris, 1997), p.70. 
C'est Polybe, l'un des plus grands historiens grecs, celui qui au II' siècle av. J.-C. arriva à Rome comme prisonnier, puis y bénéficia de l'amitié de Scipion Émilien qui devint son élève et que plus tard il aidera de ses connaissances poliorcétiques dans le siège de Carthage, c'est Polybe, disais-je, qui le fit pour la première fois, et c'est par là qu'il commence ses Histoires':

Quel homme au monde serait en effet assez stupide ou frivole pour ne pas vouloir connaitre comment et par quel mode de gouvernement presque tout le monde habité, conquis en moins de cinquante-trois ans, est passé sous une seule autorité, celle de Rome? Fait dont on ne découvre aucun précédent (...) Les Romains, en soumettant non pas quelques parties, mais la totalité du monde habité, ont laissé une puissance si étendue qu'il est impossible à nos contemporains de lui résister ni à nos descendants de la surpasser.

Pour ce qui est de l'étendue de l'empire à l'époque républicaine, on sait bien qu'elle a été surpassée par les Romains eux-mêmes. Les historiens de l'époque impériale auront grand soin de dresser un catalogue de toutes les régions qui y appartenaient. C'est ainsi que, au II' siècle après J.-C., Appien y consacrera une grande partie de la préface de son Histoire Romaine, en finissant par rattacher cet immense espace à la course du Soleil. Une telle comparaison deviendra, d'ailleurs, un vrai topos littéraire, qu'on peut retrouver chez d'autres auteurs et qui reprendra sa force au XVI' siècle, lors des grandes découvertes qui ont rendu possibles des empires encore plus vastes'.

Mais revenons à l'Antiquité. Déjà Auguste s'était plu, dans les Res Gestae, à faire ce que Claude Nicolet a appelé "l'annonce de la conquête du monde"; et pourtant il y manquait encore ce que le même historien contemporain a appelé "l'heureuse reprise de l'époque de Trajan", ce qui

"Histoires I.1.5, 2.7.

' Rappelons un exemple du début du V' siècle après J.-C., celui du poète gaulois Rutilius Namatianus, De reditu suo 57-58: Pour toi seul Phébus lui-même, dont le tour embrasse tout, chez toi se lève, chez toi couchent ses coursiers.

Pour ce qui est du XVI" siècle, un exemple très comnu est celui du début des Lusiades, lorsque Camoens, s'adressant à son roi, lui dit (I.8.1-4): Vous, puissant roi, dont le Soleil naissant aperçoit d'abord le noble cmpirc, qu'il contemple cucore au milicu de l'hénnisphère, et qu'en déclinant il laisse le dernicr (trad. R. Bismuth, Lisbonne-Paris, 1992).

'L'inventaire du monde. Géographie el politique aux origines de l'Empire Romain (Paris, 1988), p.19-20. 
nous mène à nouveau à l'époque des Antonins, c'est-à-dire, de ceux qu'on a nommés "les bons empereurs", soit Trajan, Hadrien, Antonin-le-Pieux, Marc Aurèle.

C'est aussi à cette période que se placent d'autres ouvrages qui réfléchissent à nouveau sur les causes de cet énorme succès, qui mettait les Romains bien au-dessus de tous les peuples qui précédemment avaient fait de grandes conquêtes. C'est le cas de l'histoire d'Appien et de l'éloge d'Aelius Aristide.

Dans sa préface, Appien, laissant de côté la discussion entamée par Plutarque ${ }^{7}$ à savoir, si la grandeur romaine était le résultat du mérite (arete) ou de la chance (tuche), unit les deux causes possibles de leur succès (grâce à la prudence et à la bonne chance, di' euboulian kai eutuchian) en ajoutant qu'ils ont surpassé tous les autres peuples en courage, constance et endurance (arete, phereponia, talaiporia), de sorte qu'aucune adversité ne pouvait vaincre leur résistance.

Un contemporain, le rhéteur Aristide, a écrit un discours "En l'honneur de Rome", qui est, comme l'a si bien dit Laurence Pernot dans une étude récente, "une réflexion sur l'organisation de l'Empire". C'est encore le même helléniste qui y a distingué les quatre points forts du système qui étayent son exposé: "l’Vrbs, qui, dans son rôle de capitale, dirige et coordonne le vie de l'Empire"; l'administration des provinces; l'armée, "qui veille aux frontières et écarte tout danger extérieur"; l'empereur, "sous les ordres duquel sont placées la hiérarchie militaire et l'administration civile"."

L'importance et la grandeur de la ville de Rome avaient été reconnues depuis longtemps et sont vraiment un locus communis de la littérature latine. Son emplacement pas trop près de la mer, dans une situation excellente, a été louée par Cicéron et par Vitruve ${ }^{10}$. Sa supériorité sur les autres villes a été exprimée, comme chacun le sait, au moyen d'une comparaison aux tonalités champêtres dans la I"ir Bucolique de Virgile".

"Le mot est de Christian Habicht, Pausanias' Guide to Ancient Greece (Berkeley, 1985), p.123.

'De fortuna Romanorum, surtout 316c-317e.

${ }^{8}$ Éloges Grecs de Rome (Paris, 1997), p. 29.

"Op. cit., p.29-30.

${ }^{10}$ Cicéron, De Re Publica II.3.5. Vitruve, De Architectura VI.1.10.

"Bucolica I.24-25. 
Puis la Rome impériale, celle qu'Auguste se vantait "de laisser de marbre, après l'avoir reçue en briques"', était devenue "un abrégé du monde" (epitome tes oikoumenes), selon la définition d'un contemporain d'Aristide, le rhéteur Polémon. Le mot est repris, sans nom d'auteur, par Athénée, qui en précise le sens ${ }^{13}$ :

... car on y peut d'un coup voir réellement installées toutes les cités, et la plupart avec leur caractère propre ...

En revenant à Aelius Aristide, remarquons qu'il loue surtout le pouvoir de la ville, qui s'étend vraiment partout, même jusqu'à Ostia "là où se trouvent le centre commun du commerce mondial et la gestion commune de tous les produits de la terre"". I1 n'oublie pas le réseau de voies et de ponts qui relient le territoire à la capitale ${ }^{15}$. Ce monde immense, dit-il plus loin, en employant une métaphore théâtrale, "fait entendre une seule voix, avec plus de perfection qu'un choeur, en priant à l'unisson pour que cet empire dure éternellement, tant il est bien soudé par notre prince coryphée" ${ }^{\text {"16 }}$.

Mais c'est chez Cicéron qu'on trouve une notion bien plus profonde, celle que la ville aux sept collines représente un style de vie et une idée; bref, elle est la deuxième patrie de chacun. Je répéterai seulement les paroles les plus importantes de ce texte célèbre du Traité des Lois. C'est le moment où Cicéron répond à une question d'Atticus, pourquoi a-t-il dit qu'Arpinum était sa patrie véritable":

De même nous, nous considérons comme patrie celle où nous sommes nés aussi bien que celle qui nous a accueillis. Mais il est nécessaire que celle-là l'emporte dans notre affection par laquelle le nom de "république" est le bien commun de la cité entière. C'est pour elle que nous devons mourir, c'est à elle qu'il nous faut donner tout entiers,

${ }^{12}$ Suétone, Divus Augustus 28.

${ }^{13}$ Les Deipnosophistes I.36.

"En l'homeur de Rome 171. La traduction française de tous les passages de ce discours est celle de L. Pernot, Éloges Grecs de Rome, cit..

${ }^{15}$ En I'honneur de Rome 101. Sur l'importance des voies de communication dans la politique romaine, voir Raymond Chevalier, Les Voies Romaines (Paris, 1972).

${ }^{16}$ Ibidem 29.

${ }^{17}$ De Legibus II.5.9. Cf. aussi De Oratore I.44.196. 
en elle qu'il faut déposer et pour ainsi dire sanctifier tout ce qui nous appartient. Mais la patrie qui nous a enfantés ne nous est guère moins douce que celle qui nous a accueillis.

De cette belle profession de foi politique du grand orateur, retenons surtout l'importance qu'il attache au mot-clé res publica, dont il donne la définition en divers endroits du traité qui porte ce titre-1à. Voyons-en un exemple ${ }^{18}$ :

Donc, reprit l'Africain, la république, c'est la chose du peuple; mais un peuple n'est pas un rassemblement quelconque de gens réunis n'importe comment; c'est le rassemblement d'une multitude d'individus, qui se sont associés en vertu d'un accord sur le droit et d'une communauté d'intérêts.

On croit que la doctrine exposée dans ce texte est d'origine stoïcienne. S'il en est ainsi, elle aurait vraisemblablement été transmise par le philosophe Panétius, un membre du cercle des Scipions auquel Polybe appartenait aussi. Du point de vue cicéronien, cette république ainsi conçue n'existait plus dans les dernières années de sa vie. Il le dit plusieurs fois ${ }^{19}$ :

Nous n'avons encore un État (res publica) que de nom, alors qu'en fait nous l'avons perdu depuis longtemps.

Elle ne pouvait pas exister, dit-il encore, s'il n'y avait pas dans la cité "un juste équilibre des droits, des obligations et des fonctions, si les magistrats n'ont pas assez d'autorité et le peuple pas assez de liberté”"20.

Cette tripartition (les magistrats, le sénat, le peuple) est ce qui fait que la constitution romaine soit du genus mixtum, c'est-à-dire, "celui qui résulte de la fusion harmonieuse de ces trois genres de gouvernements purs: royauté, aristocratie, démocratie", comme on le dit encore dans le De Re Publica, après une longue discussion sur ce thème si cher aux théoriciens politiques de l'Antiquitéél. D'ailleurs, ce n'était pas la première fois. que l'on exaltait la

"De Re Publica I.25.39.

"De Re Publica V.1.2. Cf. De Officïs I.11.35.

De Re Publica II.33.57.

"De Re Publica II.23.41. La discussion avail commencé à la fin du Livre I. 
constitution romaine. Polybe l'avait fait dans le Livre VI de ses Histoires, quoique le qualificatif mixtum n'y figure pas ${ }^{22}$ :

Lorsqu'on regardait le pouvoir des consuls, le régime paraissait parfaitement monarchique et royal; mais d'après le pouvoir du Sénat, c'était cette fois une aristocratie; et si maintenant on considérait le pouvoir du peuple, cela semblait être nettement une démocratie.

Le sujet revient chez d'autres auteurs et il ne pouvait pas manquer d'être mentionné dans l'Éloge d'Aelius Aristide, qui en résume le contenu en une seule phrase: "Il est comme un mélange de tous les régimes, sans la forme mauvaise de chacun”. N'oublions pas qu'à cette époque-là bien des choses avaient changé, surtout en ce qui concerne le rôle du Sénat, qui n'était plus comme Cicéron l'avait exprimé dans un appel pathétique de la III Philippique": "Souvenez-vous, enfin, que vous êtes les chefs du plus auguste conseil de l'univers". Nous ne toucherons pas à ce sujet si complexe, qui a déjà fait l'objet de plusieurs études au cours des dernières années ${ }^{25}$. Disons seulement que les relations des empereurs du Ir siècle, comme Auguste, Vespasien, Titus, avec le Sénat semblent avoir été bonnes, tandis que du temps de beaucoup d'autres empereurs, on parle plutôt de soumission, voire de persécution. Toutefois, le Sénat n'en arriva pas moins jusqu'au début du VII" siècle de notre ère.

Le Livre VI de Polybe, dont nous avons déjà parlé, fait l'étude des institutions politiques de Rome, en examinant le pouvoir des consuls, puis celui du Sénat et celui du peuple. Une autre partie est consacrée à la description de l'armée romaine, tant de son organisation que de la structure de son camp.

C'était là, comme chacun le sait, un des piliers de la grandeur romaine, qu'on croit n'avoir jamais assez étudié. On en est arrivé, récemment, à essayer de redécouvrir - et c'est là un sujet favori dés historiens modernes - la

${ }^{22}$ Polybe, Histoires VI.11.12.

${ }^{23}$ En I'honneur de Rome 90.

"Philippica III.14.34.

${ }^{2}$ Voir surtout E. Meyer, "Das politische Denken in Rom", Museum Helveticum 54 (1988) 219-247; André Chastagnol, Le Sénat Romain à l'Époque Inpériale (Paris, 1992); et Opposition et Résistance à l'Empire d'Auguste à Trajan, Entretiens Hardt, Tome XXXIII (Genève, 1986). 
composition des aliments qui ont pu produire des résultats aussi spectaculaires $^{26}$ ! Les auteurs anciens regardaient la question d'un point de vue plutôt moral et civique. Cicéron, par exemple, parle surtout de virtus et de disciplina ${ }^{27}$.

Le témoin du II" siècle après J.-C. que nous avons utilisé plusieurs fois, Aelius Aristide, consacre pas moins de treize paragraphes de son discours à ce sujet. Il a reconnu l'utilité de recruter "des hommes prêts à s'acquitter de cette fonction" dans toutes les contrées de l'empire, en leur donnant le droit de cité. "Les faisant citoyens - poursuit-il - vous les avez fait également soldats, de sorte que les hommes de votre cité ne servent pas dans l'armée, mais que les hommes qui servent dans l'armée n'en sont pas moins citoyens" ${ }^{\text {"xi }}$. Il y a plus: les fortifications ne sont pas érigées autour de la ville, comme ailleurs; elles font le tour de l'empire: "Vous n'avez pas négligé les remparts, mais vous les avez placés autour de l'Empire, non autour de la cité. Vous les avez édifiés le plus loin possible, éclatants et dignes de vous"'." Le perfectionnement et la fortification du limes a été, en effet, un des grands soucis des empereurs du II siècle de notre ère. On se rappellera la fameuse muraille d'Hadrien, en Angleterre, le pays lointain qu'Aristide appelle "la grande île du bout du monde" ${ }^{p *}$. On n'oubliera pas non plus que, sur dix-neuf ans de règne, MarcAurèle en passa la plus grande partie à défendre le limes du Danube.

L'octroi de la citoyenneté aux peuples conquis est sans doute l'une des habiletés politiques des Romains. Tout en commençant par les élites, ont finit par l'étendre à tous, par la Constitutio Antoniniana (212 après J.-C.). Plusieurs textes, depuis Tacite jusqu'à Dion Cassius, rendent témoignage de l'évolution de cette procédure". On comprend qu'Aristide ait pu écrire dans un passage célèbre de son discours ${ }^{32}$ :

Vous ne divisez pas aujourd'hui les races en Grecs et barbares, mais vous n'avez pas non plus fait paraitre cette division ridicule pour elles en

${ }^{26}$ Marcus Junkelmann, Panis militaris (München, 1997).

${ }^{27}$ Tusculanae I.1.2.

${ }^{2}$ En I'honneur de Rome 75.

${ }^{21}$ En I'honneur de Rome 81.

${ }^{30}$ En I'honneur de Rome 82. Voir aussi ibidem 28.

"Pour la bibliographie ancienne et moderne à ce sujet, voir L. Pernot, Éloges Grecs de Rome (Paris, 1997), p.88-89, note 115.

${ }^{32}$ En l'honneur de Rome 63. 
présentant une cité plus peuplée que l'ensemble, peut-on dire, de la gent hellénique, mais vous l'avez remplacée par la division en Romains et non-Romains.

L'opposition entre Grecs et barbares était une vieille querelle que nous n'allons pas ranimer ici. Rappelons plutôt les paroles d'Aristide quelques paragraphes avant celui-ci, qui sont encore pus claires ${ }^{33}$ :

Ni mer ni distance terrestre n'excluent de la citoyenneté et entre I'Asie et l'Europe il n'y a pas de différence sur ce point. Tout est mis à la portée de tous; nul n'est étranger s'il mérite une charge ou la confiance.

Donc, unité et pluralité sur tout le territoire de l'Empire. Mais, dans toute cette étendue, il y avait un cas singulier, reconnu comme tel depuis le temps de la République: c'était, bien sûr, celui de la Grèce, celle qui avait été vaincue en 146 avant J.-C., et qui avait ensuite dompté son féroce vainqueur, selon le mot célèbre d'Horace ${ }^{34}$. Les rapports entre les deux pays avaient commencé, pourtant, beaucoup pus tôt, et les fouilles archéologiques et les trouvailles épigraphiques au Latium, au cours des dernières décennies, en font de plus en plus reculer la date.

L'alphabet, par exemple, qu'il soit parvenu a Rome par la Grande Grèce ou par l'intermédiaire des Étrusques, y était connu au VII' siècle avant J.-C. Les contacts réguliers avec Capoue et Naples commencèrent vers 340 avant J.-C., par suite de l'annexion de la Campanie. Mais rien ne semble plus significatif que le fait qu'un prisonnier de Tarente, Livius Andronicus, ait reçu du Sénat l'ordre de traduire du grec, sa langue maternelle, une pièce de théâtre pour être jouée aux Ludi Romani de 24.0 avant J.-C., en commémoration de la fin de la Première Guerre Punique. C'est encore ce même Livius Andronicus qui, ayant une école à Rome, a traduit en latin l'Odyssée, inaugurant par là la Littérature Latine.

Au cours des siècles, les Romains ne cesseront de proclamer les origines grecques de leur culture. Même la Loi des Douze Tables, la "charte de fondation du Droit Civil”, comme l'a appelée F. Wieacker", se serait inspirée

${ }^{33}$ En l'honneur de Rome 60.

${ }^{31}$ Epistulae II.1.156.

"s "Dic XII Tafeln in ihrem Jahrhundert" in: Les Origines de la République Romaine, Entretiens Hardt, Tome XIII (Genève, 1967), p.353. Voir aussi à ce sujet Michelle Ducos, L'Influence Grecque sur la Loi des Douze Tables (Paris, 1978). 
de l'étude de la législation grecque, d'après la tradition rapportée par Tite-Live et d'autres historiens anciens ${ }^{36}$. Mais c'est surtout après la première moitié di II' siècle avant J.-C., c'est-à-dire, sous l'influence de ce qu'on est convenu d'appeler "le cercle des Scipions", que l'hellénisation devient de plus en plus évidente. On pourrait en fournir des preuves a n'en plus finir, surtout chez les grands écrivains. Plus que tout autre, Cicéron ne se lasse pas de reconnaitre les origines grecques de la poésie, des arts, des sciences. Choisissons-en un seul exemple, celui qui se trouve dans la longue lettre qu'il a adressée a son frère Quintus, à l'occasion de sa troisième nomination au proconsulat de l'Asie (c'est-à-dire, de l'ancien royaume de Pergame, donc celui où se trouvaient les anciennes villes grecques) ${ }^{37}$ :

Je ne rougirais pas, en effet, de le dire, surtout quand ma vie et mes actes ne peuvent prêter au moindre soupçon d'indolence ou de légèreté: ce que nous sommes devenus, nous le devons à des études, à des sciences et arts qui nous ont été transmis par les oeuvres et les enseignements de la Grèce.

Ceci ne l'avait pas empêché de s'efforcer d'attribuer aux Romains des qualités uniques, celles qui ont fait leur grandeur. Parmi plusieurs exemples, rappelons-en ces mots de l'ouverture des Tusculanes"

Où trouver un degré de dignité, un degré de fermeté, de grandeur d'âme, de probité, de loyauté, où trouver, dis-je, chez aucun peuple, une supériorité de mérite à tous les points de vue telle qu'on puisse la mettre en parallèle avec nos aïeux? Sous le rapport de la culture générale, il est vrai, et dans tous les genres littéraires, les Grecs l'emportaient sur nous.

Donc, gravitas, constantia, magnitudo animi, fides étaient autant de qualités dont les Romains étaient parés. La dernière nommée était tellement éminente dans leur rapport avec les autres nations que V. Pöschl a pu écrire qu'elle était le centre de l'ordre politique, social et juridique de Rome ${ }^{39}$. Elle

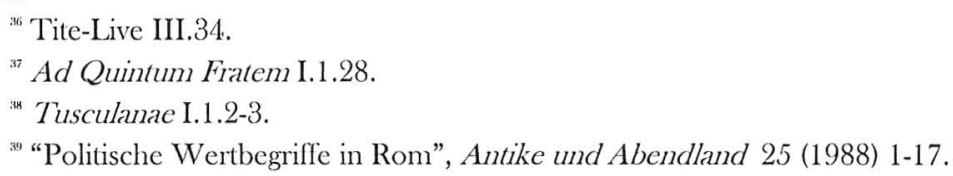


est aussi, ne l'oublions pas, dans l'Ancien Testament, dans le Livre des Maccabées. Ajoutons-y clementia, iustitia et nous aurons dénombré les grandes vertus qui ont fait la supériorité de l'empire.

Tout ceci a été résumé d'une façon inoubliable dans les quelques vers que Virgile met dans la bouche d'Anchise lorsqu'il est près de finir la revue des futurs héros issus de sa descendance. Tout y est: la supériorité de la culture grecque (les arts, l'éloquence, les sciences), les valeurs romaines (la paix, la clémence, la justice). Ce sont des vers que chacun connaît, et que vous me permettrez de rappeler d'abord dans toute la beauté de l'original":

excudent alii spirantia mollius aera, credo equidem, vivos ducent de marmore voltus, orabunt causas melius, caelique meatus describant radio et surgentia sidera dicent; tu regere imperio populos, Romane, memento (hae tibi erunt artes), pacique imponere morem, parcere subiectis et debellare superbos.

D'autres forgeront avec plus de grâce des bronzes qui sauront respirer, je le crois du moins, ils tireront du marbre des visages vivants, ils plaideront mieux, ils figureront avec leur baguette les mouvements du ciel, diront le lever des astres; à toi de diriger les peuples sous ta loi, Romain, qu'il t'en souvienne - ce seront là tes arts a toi - et de donner tes règles à la paix: respecter les soumis, désarmer les superbes.

Cette longue digression sur l'attitude intellectuelle des Romains face aux Grecs avait un but précis: celui de démontrer jusqu'à quel point ils étaient capables de respecter la pluralité des nations qui leur étaient soumises. Malgré les excès auxquels se livra Sylla, lors du sac d'Athènes (il n'en commit pas moins, d'ailleurs, dans son propre pays), qui ont fait que Pausanias écrive qu'il avait agi avec une cruauté à laquelle on ne s'attendait pas de la part d'un Romain", ce même auteur fit l'éloge des empereurs qu'on appelle philhellènes - ceux de la dynastie des Antonins - et il est allé jusqu'au point de déclarer

\footnotetext{
"Énéide VI.847-853.

"I.20.7.
} 
qu'Hadrien avait "témoigné tant de bienfaits envers tout l'Empire et tout particulièrement à l'égard de la cité d'Athènes»"

N'oublions pas que, justement du temps de Pausanias, quelques provinces d'Asie Mineure étaient gouvernées par des Romains choisis parmi les pus illustres: Tacite était proconsul de ce qu'on appelait alors l'Asie (l'ancien royaume de Pergame), son ami Pline le Jeune l'était de la Bithynie. L'empereur subventionnait des chaires de Rhétorique à Athènes, tout comme à Rome ${ }^{13}$. À la fin du IV $\mathrm{V}^{c}$ siècle de notre ère - notons-le en passant - Saint Augustin a enseigné la Rhétorique à Milan et à Rome, après l'avoir enseignée à Thagaste, sa ville natale, et à Carthage.

La correspondance de Pline le Jeune avec l'empereur a été conservée: outre la liaison étroite entre Trajan et son légat, qui lui rend des comptes et demande son avis sur tout ce qui est important, elle nous laisse entrevoir un pays qui s'adonne à la culture et aux activités sportives: on bâtit ici un théâtre, là un gymnase, ailleurs des thermes; les architectes me manquent pas". Ceci s'accord parfaitement avec le témoignage d'Aristide" : "Tout est plein de gymnases, de fontaines, de propylées, de temples, d'ateliers, d'écoles". L'épigraphie confirme, souvent de la manière la plus inattendue, que, même près du limes, bien loin de la contrée la plus cultivée de l'Empire, il y avait des écoles. C'est ce que suggère une inscription trouvée à Aventicum, caput civitatis Helvetiorum, qui parle d'une école et de l'érection de statues; une autre encore porte une dédicace d'un citoyen et de son affranchi, qui "ont fait ériger cette pierre en l'honneur des médecins et professeurs" ", ce qui suggère l'existence d'une école de médecine locale.

Sur un si vaste sujet, ce n'est qu'une esquisse que je vous ai présentée. Les meilleurs spécialistes actuels ont bien montré comment les historiens de notre siècle ont souvent orienté leurs recherches d'après les idéologies à la mode'. C'est là un biais que je me suis efforcée d'éviter. J'ai voulu simplement déceler, grâce au témoignage des écrivains anciens - surtout de ceux qui,

${ }^{12}$ I.3.2.

${ }^{13}$ Cf. Chr. Habicht, Pausanias' Guide to Ancient Greece, cit., p.124, 128.

"Voir, par exemple, la lettre X.40, de Trajan à Pline le Jeune.

is En I'honneur de Rome 97.

${ }^{16}$ Les deux textes sont reproduits dans Corpus Inscriptionum Latinarum et aussi dans le guide de Hans Bögli, Aventicum. La ville romaine et musée (Fribourg, $\left.{ }^{3} 1996\right)$ ), p.61 et 85.

"Voir surtout A. Momigliano, "Some Preliminary Remarks on the 'Religious Opposition' in the Roman Empire" in: Opposition et Résistance à l'Empire d'Auguste à Tiajan, cit., p. 103-105; Evangelos Chrysos in.: The Transformation of the Roman World, cit., Vol. I, p.185-206. 
n'étant pas Romains de naissance, avaient chance d'être plus objectifs - des aspects intéressant l'acculturation de peuples d'origine si différente.

C'est peut-être l'occasion de se demander: ces exemples peuvent-ils encore nous apprendre quelque chose? L'Europe, parce qu'on va revenir à la monnaie unique et à l'inexistence de frontières, comme au temps des Césars, formera-t-elle en quelque sorte une union semblable à celle que nous venons d'évoquer? Ce sont là des conditions pareilles, bien sûr, auxquelles on peut s'attendre dans un futur qui ne sera pas trop lointain, espérons-le. Mais, au-delà de ces clauses économiques et politiques, il faut regarder plus haut. Il faut, comme l'a reconnu il y a dix ans, le ministère des Affaires Étrangères français, que la culture soit capable d'imposer le sentiment de l'unité, de la solidarité européenne. Une grande partie de ce sentiment d'unité découle des valeurs classiques qui sont aux assises de notre tradition culturelle. Ce sont elles qui ont moulé l'humanisme, l'humanitas dont nous devons nous réclamer. 


\title{
EUROPA EN EL IMAGINARIO DE LOS POETAS LATINOS
}

\author{
Antonio Alvar Ezquerra \\ (Universidad de Alcalá)
}

\section{Introducción}

La idea que sobre Europa puedan tener los poetas latinos - no los prosistas que, como historiadores, corógrafos y geógrafos, suelen tener una idea más técnica y de escaso calado popular -, puede ser representativa de la idea que sobre Europa pudiera tener el romano medianamente cultivado.

Cualquier investigacion sobre esta idea en la literatura latina parte, como es de rigor en otros muchos casos, de la literatura griega, que en este punto es fuente necesaria e indispensable, de modo que las aportaciones romanas son una reelaboración - con las peculiaridades coyunturales que se expondrán a continuación - de las aportaciones griegas'.

\section{El nombre de Europa}

La voz Europa es en latín - como en griego - una voz polisémica pues es, en principio y de una parte, un nombre propio que se aplica a diversas heroinas míticas ${ }^{2}$ y, en particular, a la joven hija de Agénor y Telefasa, hermana de Cadmo y Calcis, raptada en las playas de Sidón por Zeus, bajo forma y apariencia de toro, y llevada a la isla de Creta. Allí dio a luz tres hijos, Minos, Radamante y Sarpedón, mientras que el toro fue catasterizado en la constelación conocida como Tauro. p. $15 \mathrm{ss}$.

' Vid. F. Rodríguez Adrados, ¿Qué es Europa? CQué es Espania?, Madrid, RAH, 2004,

${ }^{2}$ Vid. A. Ruiz de Elvira, Mitología clásica, Madrid, Gredos, 1975, p.131, 172-173. 
Pero Europa es también el nombre que recibe una de las partes del mundo, aquélla precisamente en que se desarrolla de manera principal, aunque no exclusiva, la civilización griega, primero, y la civilización romana, después.

Desde un punto de vista estrictamente lingüístico, en los poetas latinos se atestiguan dos formas diferentes del nombre, una, a la griega, Europe, otra, a la latina, Europa. Ambas formas coexisten, incluso en un mismo autor y en una misma obra, para referirse tanto a la heroína mítica como a la parte del mundo, de modo que resulta inútil la pretensión de diferenciar una u otra acepción recurriendo al uso de una u otra forma. Además ambas formas coexisten a lo largo de varios siglos, por más que finalmente se imponga la forma latina, Europa, de la que derivan las diferentes formas que esa voz reviste en las lenguas actuales.

Etimológicamente, Europa parece significar "la de amplia mirada"; la relación con el viento Eurus (¿"viento amplio"?), al igual que Africa parece derivar como adjetivo del sustantivo Africus, o Libya del viento Lybs, no es segura.

La posibilidad de que el nombre de la joven y el nombre de la parte del mundo sean, en realidad, dos nombres distintos, de etimologías diferentes, que convergen en resultados homófonos, no ha sido suficientemente explicada $y$, desde luego, es completamente ajena al imaginario de los poetas latinos, quienes creen y dicen expresamente que la joven da su nombre al continente, como tantas otras veces ocurre en otros episodios míticos. Baste con aducir un testimonio como el de Hor. Carm. III 27, v.25-28, 57-60 y 73-76:

sic et Europe niveum doloso

credidit tauro latus et scatentem

beluis pontum mediasque fraudes

palluit audax.

(...)

vilis Europe, pater urget absens,

quid mori cessas? potes hac ab orno

pendulum zona bene te secuta

20

laedere collum.

(...)

uxor invicti Iovis esse nescis:

mitte singultus, bene ferre magnam

disce fortunatam; tua sectus orbis

nomina ducet.

${ }^{3}$ Otro testimonio en Man. Astr: IV 681-685, cit. infia. 
[Así Europa confió su níveo cuerpo

al toro seductor palideciendo

audaz ante las fieras y peligros

que el ponto infestan.

(...)

"Vil Europa”, apremia tu padre ausente,

“¿por qué no mueres ya? puedes de este olmo

colgado del cinto que llevas aún

dañar tu cuello".

(...)

Esposa de Jove invicto ignoras que eres:

deja los llantos, a soportar tu inmensa

fortuna aprende; una parte del orbe

llevará tu nombre.] M. F. G. y A. A. E.

Sin embargo, los poetas latinos no explican el proceso de traslación semántica de acuerdo con el cual una joven raptada en Sidón y abandonada en Creta da su nombre a una región geográfica situada inicialmente en la Península Balcánica, como se dice explícitamente en el Himno homérico a Apolo (v. 247-252):

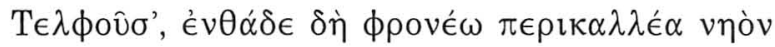

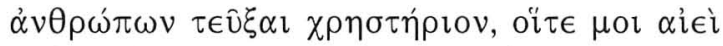

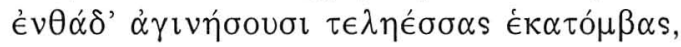

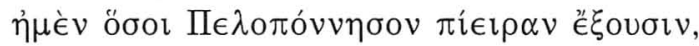

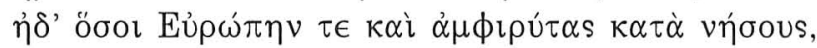

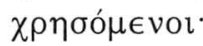

[Telfusa, aquí mismo pienso procurarme un templo hermosísimo, como oráculo para los hombres que por siempre traerán aquí hecatombes perfectas, ya sea cuantos habitan el fértil Peloponeso, ya cuantos habitan Europa y en las islas ceñidas por las corrientes, dispuestos a consultar el oráculo.]

'Vid. también v.287-292, repetición casi literal del anterior:

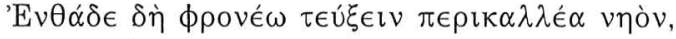

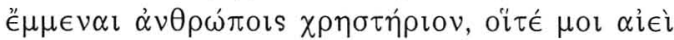

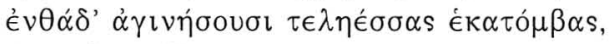

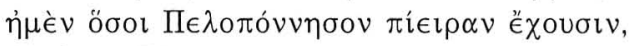

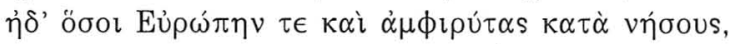
$\chi \rho \eta \sigma o ́ \mu \in$ vor.

[Aquí pienso procurarme um templo hermosísimo a fin de que sea oráculo para los hombres que por siempre me traerán aquí hecatombes perfectas, ya en las islas ceñidas por las corrientes, dispuestos a consultar el oráculo]. 
Que ese proceso tenga que ver con el hecho de que Europa sea hermana de Cadmo, el fundador de Tebas, es una suposición con escasa consistencia. El único poeta latino que afirma expresamente la directa relación entre ambos nombres como un regalo - otro más - de los que Júpiter hace a la joven raptada es Manilio en Astr: IV 681-685:

quod superest Europa tenet, quae prima natantem

fluctibus excepitque Iovem taurumque resolvit,

ponere passa suos ignes, onerique iugavit.

ille puellari donavit nomine litus

et monumenta sui titulo sacravit amoris...

[Lo que resta lo ocupa Europa, que fue la primera en recibir a Júpiter cuando nadaba en el mar, soltó al toro y consintió en poner encima su pasión, uniéndolo a la carga. Él le regaló la playa, a la que llamó como ella, consagrando con el nombre el recuerdo de su amor...] F. C. - M $\mathrm{J}$ J. E.

Pero Manilio no explica por qué razón Creta nunca se consideró parte del continente europeo (para la administración romana esa isla forma parte de la Cirenaica), ni de qué modo el nombre de Europa pudo haber pasado después al continente situado al norte de la isla.

\section{Europa, hija de Agenor, hermana de Cadmo}

Las referencias a Europa, la joven sidonia, en los poetas latinos son abundantes; naturalmente, suele aparecer su nombre en las relaciones de famosas amadas por Júpiter. Un solo texto, tomado de App. Verg. Aetna 87-90, servirá para ejemplificar este uso:

norunt bella deum, norunt abscondita nobis

coniugia et falsa quotiens sub imagine peccet

taurus in Europen, in Ledam candidus ales

Iuppiter, ut Danaae pretiosus fluxerit imber.

Además de los textos citados por extenso en el cuerpo de este estudio, véanse cstos otros: Ac. (Non. 120M; aunque no es absolutamente seguro que se refiera a la joven sidonia); Prop. II, XXVIII 51-54; Hor. Carm. III 27, 25-28, 57-60 y 73-76 (en esta última estrofa, con referencia explícita a la relación entre la joven y el continente, como ha quedado dicho más arriba); Ov. Anı. I, III 21-24; X 1-8; III, XII 33-34; Her: IV 55-60; A. A. I 321-324; III 251-254; Met. VI 103-107; VIII 23-27; 119-125; Germ. Arat. 531-534; Man. Asti: II: 486-488; Sen. HerF 1-9; Sen. Oct. 762-772; Stat. Ach. II 72-77; Mart. Epigr. lib. XVI, b; Epig7: XIV, CLXXX; Sid. Apol. XV Epit.174-175. 
IConocen (sc: los poetas) sus guerras, conocen sus bodas ocultas a nosotros, y cuántas veces bajo apariencia engañosa comete una falta Júpiter, como toro con Europa, como cisne con Leda, de qué manera se deslizó para Dánae como lluvia de oro.] A. S. R.

Obviamente, a partir de esta acepción, los poetas latinos se refieren a realidades diversas a las que se aplica el nombre de la joven: así, Marcial evoca en diversas ocasiones el Pórtico de Europa, un bello lugar de la Urbe, frecuentado por gentes ociosas. Así, en Mart. Epigr: II, XIV":

Nil intemptatum Selius, nil linquit inausum,

Cenandum quotiens iam videt esse domi.

Currit ad Europen et te, Pauline, tuosque

Laudat Achilleos, sed sine fine, pedes.

Si nihil Europe fecit, tunc Saepta petuntur,

Si quid Phillyrides praestet et Aesonides.

Hic quoque deceptus Memphitica templa frequentat.

Adsidet et cathedris, maesta iuvenca, tuis.

Inde petit centum pendentia tecta columnis,

Illinc Pompei dona nemusque duplex.

Nec Fortunati spernit nec balnea fausti,

Nec Grylli tenebras Aeoliamque Lupi:

Nam thermis iterumque iterumque iterumque lavatur.

Omnia cum fecit, sed renuente deo,

Lotus ad Europes tepidae buxeta recurrit,

Si quis ibi serum carpat amicus iter.

Per te perque tuam, vector lascive, puellam,

Ad cenam Selium tu, rogo, taure, voca.

[Selio no deja nada sin intentar, nada sin ensayar, siempre que ve que ya tiene que cenar en casa. Acude corriendo al pórtico de Europa y te alaba, Paulino, y alaba sin fin tus pies ágiles como los de Aquiles. Si el pórtico de Europa no ha proporcionado nada, se dirige entonces a los Septa por si allí el hijo de Filira o el de Esón le brindan algo. Defraudado también aquí, a menudo va a los templos de las diosas de Menfis y se sienta en tus sillas, afligida novilla. Se encamina después hacia los techos que

"Vid. otros casos similares en Mart. Epigi: III, XX (Europae); VII, XXXII (Sidonio taurus amore calet); o XI, I (Agenoris puella). 
penden de cien columnas y desde allí a los edificios regalados por Pompeyo y a sus dos bosques. Y no desprecia los baños de Fortunato ni los de fausto, ni los oscuros sótanos de Grilo y el antro de Eolo de Lupo, pues se baña en las termas una, otra y otra vez. Cuando ya ha intentado todo, pero sin el asentimiento de la divinidad, una vez bañado, corre de nuevo hacia los bojedales del templado pórtico de Europa por ver si algún amigo se dirige allí tardíamente. Por ti y por tu muchacha, Toro raptor lascivo, invita, te ruego, a cenar a Selio.l D. E. A.

Silio Itálico, por su parte, alude en Pun. XIV 562-574, a un navío, naturalmente púnico, llamado "Europa" y que con seguridad tenía representada en su mascarón de proa la escena del rapto de la joven:

Concessere mari tandem Graiusque Libysque, et iam captiuae uinclis ad litora longo ordine ducuntur puppes. flagrantibus alto stant aliae taedis. splendet lucente profundo Mulciber, et tremula uibratur imagine pontus. ardet nota fretis Cyane pennataque Siren, ardet et Europe, niuei sub imagine tauri uecta Ioue ac prenso tramittens aequora cornu, et quae fusa comas curuum per caerula piscem Nereis umenti moderatur roscida freno. uritur undiuagus Python et corniger Hammon et, quae Sidonios uultus portabat Elissae, bis ternis ratis ordinibus grassata per undas.

[Finalmente, griegos y libios abandonan el mar; sus naves apresadas y encadenadas las unas a las otras, son conducidas en larga fila hasta la orilla. Otras permanecen en alta mar, envueltas en llamas. Relucen las profundidades con el brillo de Mulcíber, vibran las aguas con su trémulo reflejo. Arde Cíane, bien conocida en aquellos mares, y la veloz Sirena. Arde también Europa, guiada por Júpiter transformado en un toro blanco como la nieve y surcando los mares agarrada a sus cuernos. Arde también, salpicada por las olas, Nereida, sueltos los cabellos, guiando por el azul del mar su pez encabritado con las riendas mojadas. Se consume Pitón, que vaga por las aguas, la cornígera Amón y aquella otra nave que llevaba la efigie de la sidonia Elissa y avanzaba a través de las olas impulsada por seis filas de remeros.l J. V. A. 
Y, por último, Juvenal en VIII 32-34 indica que Europa era mote conocido de jóvenes contrahechas o jorobadas?

...nanum cuiusdam Atlanta uocamus,

Aethiopem Cycnum, prauam extortamque puellam

Europen.

[Al enano de cierto individuo llamamos "Atlas", a un etíope "Cisne", a una muchacha deforme y jorobada "Europa".l F. S.

\section{Europa, una parte del mundo}

Pero, a los efectos que ahora interesan, Europa es, sobre todo, una parte del mundo y ésa es la acepción que ha perdurado hasta nuestros días. En este sentido, Europa es, en principio, más que una realidad sustantiva, un espacio geográfico que se opone a Asia, de manera muy principal, y a Libia/África, en segundo lugar. De modo que en la poesía latina la aparición de uno de esos términos exige - casi de forma automática - la aparición de alguno de los otros dos o de los otros dos. Así ocurre desde Enio, según se lee en Ann. IX 302 para la oposición Europa / África (= Cic. Tusc. I 45,9: Europam Libyamque rapax ubi diuidit unda (A Europa y Libia las divide una ola rapaz. A. A. E.]) o desde Catulo LXVIII 87-92 para la oposición Europa / Asia":

Nam tu Helenae raptu primores Argiuorum coeperat ad sese Troia ciere uiros,

'Quizás por antítesis, tal como sin duda ocurre con el enano que en este mismo texto recibe el apelativo de "Atlas", o con el etíope (de negra piel) que recibe el apelativo de "Cisne". Estc pasaje conviene ponerlo en relación con otro bien conocido de Lucrecio IV 1160-1170:

$$
\begin{aligned}
& \text { nigra melichrus est, inmunda et fetida acosmos, } \\
& \text { caesia Palladium, nervosa et lignea dorcas, } \\
& \text { parvula, pumilio, chariton mia, tota merum sal, } \\
& \text { magna atque inmanis cataplexis plenaque honoris. } \\
& \text { balba loqui non quit, traulizi, muta pudens est; } \\
& \text { at flagrans, odiosa, loquacula Lampadium fit. } \\
& \text { ischnon eromenion tum fit, cum vivere non quit } \\
& \text { prae macie; rhadine verost iam mortua tussi. } \\
& \text { at nimia et mammosa Ceres est ipsa ab Iaccho, } \\
& \text { simula Silena ac Saturast, labeosa philema. } \\
& \text { cetera de genere hoc longum est si dicere coner. }
\end{aligned}
$$

" Además de los textos citados en el cuerpo de este estudio, véanse estos otros: Ov. Met. V 642-649 (iam super Europen ... et Asida terram); Luc. III 269-276 (Tanais diversi nomina mundi / inposuit ripis Asiaeque et terminus idem / Europae...); Luc. IX 869-874 (citado por cxtenso más adelante); Val. Fl. Arg: II 613-615 (citado más adelante); o IV 724-728 (hac Europam curvis anfiactibus urget, / hac Asian). 
Troia (nefas!) commune sepulcrum Asiae Europaeque,

Troia uirum et uirtutum omnium acerba cinis,

quaene etiam nostro letum miserabile fratri

attulit.

[Pues entonces Troya, debido al rapto de Helena, empezó

a convocar a los caudillos argivos,

Troya, jhorror!, tumba común de Asia y Europa,

Troya, amarga pira de héroes y gestas,

que también llevó la desgraciada muerte a mi

hermano...] A. R. V.

A este respecto, resulta muy significativo un pasaje de Virgilio (Aen. I 372-385), donde se oponen de manera explícita las tres partes del mundo":

'O dea, si prima repetens ab origine pergam

et uacet annalis nostrorum audire laborum, ante diem clauso componet Vesper Olympo.

nos Troia antiqua, si uestras forte per auris

Troiae nomen iit, diuersa per aequora uectos

forte sua Libycis tempestas appulit oris.

sum pius Aeneas, raptos qui ex hoste penatis

classe ueho mecum, fama super aethera notus;

Italiam quaero patriam, et genus ab Ioue summo.

bis denis Phrygium conscendi nauibus aequor,

matre dea monstrante uiam data fata secutus;

uix septem conuulsae undis Euroque supersunt.

ipse ignotus, egens, Libyae deserta peragro,

Europa atque Asia pulsus.'

[«Si, evocando los inicios, oh diosa, del origen partiera

y tuvieras tiempo de oír año por año nuestros esfuerzos, antes pondría Véspero el día en el Olimpo cerrado.

De Troya antigua a nosotros, si por azar por vuestros oídos

el nombre de Troya anda, a través de llanuras varias llevados

una tempestad por azar nos empujó a las costas de Libia.

Soy Eneas piadoso y los penates, salvados del enemigo, en mi escuadra llevo, más allá de los cielos famoso;

\footnotetext{
"Vid. un pasaje similar, donde el personaje de Eneas queda sustituido por el de Pompeyo en Luc. VI 812-818 (citado por extenso más adelante).
} 
Busco Italia, mi patria, y mi estirpe de Jove excelso procede.

Con dos veces diez naves entré en la frigia llanura,

siguiendo hados fijos, tras mostrar mi madre diosa el camino;

apenas siete, golpeadas por olas y Euro, me restan.

Yo mismo, ignorado, sin nada, desiertos de Libia recorro,

expulsado de Europa y Asia.»] A. A. E.

Ese espacio geográfico conocido por los poetas latinos con el nombre de Europa (o Europe) tiene unos límites poco precisos pero que, en términos generales, pueden definirse del siguiente modo: a Occidente, el Océano Atlántico, al norte los Océanos Británico y Escítico, al sur el Mar Medi-terráneo - que lo separa de África, la tercera parte del mundo ${ }^{10}$ - y al oriente el río Tanais - el Don"-, además del Bósforo y del Mar

${ }^{10}$ Según se lec en Hor. Carm. III 3, 45-48:

horrenda late nomen in ultimas

extendat oras, qua medius liquor

secernit Europen ab Afro,

qua tumidus rigat arva Nilus.

[Su nombre terrible hasta los últimos

confines extienda (sc. Roma), por donde el agua

parte Europa de lo africano,

do henchido riega campos el Nilo.] A. A. E.

"Vid. Luc. III 269-276., ya cit. A ese río se refiere, sin duda, Ovidio en Pont. IV, X 47-58:

Huc Lycus, huc Sagaris Peniusque Hypanisque Calesque influit et crebro uertice tortus Halys

Partheniusque rapax et uoluens saxa Cynapses

labitur et nullo tardior amme Tyras,

et tu, femineae Thermodon cognite turmae

et quondam Graiis Phasi petite uiris,

cumque Borysthenio liquidissimus amne Dyraspes

et tacite peragens lene Melanthus iter,

quique duas terras, Asiam Cadmique sororem,

separat et cursus inter utramque facit,

innumerique alii, quos inter maximus omnis

cedere Danuuius se tibi, Nile, negat.

IAllá el Lico, allá el Ságaris, y el Penio y el Hípanis y el Cales, y desemboca también, retorcido cn su continuo remolino el Halis, y el Partenio voraz, y arrastrando rocas se desliza el Cinapses y más lento que ninguna corriente el Tiras, y tú, Termodonte, conocido para el tropel de mujeres, y el Fasis, requerido un día por los hombres griegos, y con el Boristenio el Diraspcs, de transparentisimo caudal, y en silencio el Melanto, recorriendo suavemente su camino, y el que separa dos tierras, Asia y la hermana de Cadmo y hace sus recorridos entre una y otra, y los innumerables otros entre todos los cuales el más grande, el Danubio, se niega a ceder ante ti, Nilo.] A. P. V. 
Negro $^{12}$. De modo que, en el imaginario de los poetas latinos, el actual territorio ruso al este del Don no formaba parte de Europa ${ }^{13}$, al igual que buena parte de Egipto no formaba parte de África por ser precisamente el río Nilo la línea divisoria entre África/Libia y Asia". Bastaría citar un pasaje de Lucano (IX 4.11-4.17) para dibujar el mapa imaginado de las tres partes del mundo:

tertia pars rerum Libye, si credere famae cuncta uelis; at, si uentos caelumque sequaris, pars erit Europae. nec enim plus litora Nili quam Scythicus Tanais primis a Gadibus absunt, unde Europa fugit Libyen et litora flexu

Oceano fecere locum; sed maior in unam orbis abit Asiam.

[Libia es, si quieres conceder crédito completo a la opinión común, la tercera parte del mundo; mas si atiendes a los vientos y a su cielo, forma parte de Europa. En efecto, no distan más las orillas del Nilo que el Tanais escita del extremo Gades, de donde Europa huye a Libia, y las costas curvándose cedieron espacio al Océano; una parte mayor del mundo, en cambio, se halla separada formando Asia sola.] J.B.G.

Naturalmente, para los poetas latinos otras regiones hoy europeas eran desconocidas pues para ellos al norte de la Germania, de la Sarmatia, de la Escitia y de los Hiperbóreos no había más que agua. La Península Escandinava y las lejanas islas Britannia (Gran Bretaña), Hibernia (Irlanda) o Thule (Islandia) apenas estaban incorporadas al conocimiento de estos poetas

${ }^{12}$ Vid. Luc. IX 957-960:

non Asiam breuioris aquae disterminat usquam fluctus ab Europa, quamuis Byzantion arto Pontus et ostriferam dirimat Calchedona cursu, Euxinumque ferens paruo ruat ore Propontis.

[En ningún lugar una corriente menor de agua a Asia de Europa delimita, aunque el Ponto con un canal estrecho separa Bizancio y la ostrífera Calcedonia, y aunque irrumpa por una pequeña boca la Propóntide, que transporta las aguas al Euxino.] J.B.G.

'Fue el geógrafo e historiador ruso Tatishchev, ya del s: XVIII, quien extendió los territorios de Europa hasta los Urales. Vid. Rodríguez Adrados, ya cit., p.16.

"Vid. a este respecto, por ejemplo, Sil. Ital. Pum. I 189-200. 
y, en cualquier caso, no se asociaban a la idea geográfica de Europa, reducida a las tierras continentales. Así, Europa - como cualquiera de los otros continentes - era concebida como un espacio unitario de tierra firme rodeado de agua por todas partes, sea agua del mar, o sea corriente fluvial.

Las reiteradas menciones de este espacio geográfico, sin embargo, no van acompañadas de descripciones que caractericen ese territorio, ni de enumeraciones de los pueblos o naciones que lo habitan, ni de descripciones de sus costumbres o de celebraciones de las virtudes que puedan adornarlos en oposición a los de otros continentes. En definitiva, Europa no es más que una vaga referencia geográfica aún no perfilada.

Es, no obstante, una excepción a esta generalizada situación un pasaje de Manilio en donde se lee el primer elogio, aunque breve, de Europa en la literatura latina, que se hace seguir por una enumeración celebrativa de los pueblos que la integran. Dice así el texto de Manilio, a continuación del ya citado más arriba (Astr. IV 686-695):

\section{maxima terra viris et fecundissima doctis}

artibus: in regnum florentes oris Athenae;

Sparta manu, Thebae divis, et rege vel uno princeps Pella domus, Troiani gratia belli; Thessalia Epirosque potens vicinaque ripa Illyris, et Thrace Martem sortita colonum, et stupefacta suos inter Germania partus;

Gallia per census, Hispania maxima bellis;

Italia in summa, quam rerum maxima Roma imposuit terris caeloque adiungitur ipsa.

[...Es ( $s c$. Europa) la tierra más grande por sus hombres y la más fecunda en las artes de la sabiduría: Atenas sobresale en el dominio de la elocuencia, Esparta en las armas, Tebas por sus dioses, por un solo rey tiene el principado la casa de Pela, honra de la guerra de Troya; tienen gran poder Tesalia, el Epiro, Iliria, su vecina en el litoral, Tracia, que tuvo la suerte de contar a Marte entre sus hijos, Germania, que se queda atónita ante sus hijos, Galia, la más destacada por su riqueza, como Hispania lo es por su belicosidad; finalmente Italia, a la que Roma, la ciudad más poderosa del mundo y ella misma incorporada a las divinidades, ha hecho dueña de la tierra.] F. C. - $\mathrm{M}^{\mathrm{a}} \mathrm{J}$. E.

Resulta interesante subrayar que por vez primera se agrupan al mismo nivel y haciéndolos formar parte de una unidad superior llamada Europa no solo los diversos territorios que forman parte del Estado romano en esa parte 
del mundo - desde Grecia a Hispania ${ }^{1.5}$, pasando por la Galia y, obviamente, Italia -, sino también otro pueblo ajeno al Imperio y confrontado con él, a saber, Germania. Todos esos pueblos conforman esa Europa hasta este momento evanescente y brumosa. Mas debe señalarse que en la enumeración de Manilio faltan otros pueblos sin duda ubicados por el imaginario romano en esa misma parte del mundo - como los escitas o los hiperbóreos -, al tiempo que están ausentes otros ni siquiera imaginados en el momento en que escribe el poeta latino, como son los escandinavos. Finalmente, faltan también todos aquellos que habitan las islas de Britannia, Hibernia o Thule, así como las del Mediterráneo, por cuanto un continente se concibe, como ha quedado dicho, como un espacio unitario de tierra firme, por lo que no han de incluirse bajo su denominación los territorios insulares.

$\mathrm{Y}$, por ser precisos, habría que añadir otro pasaje de Lucano (IX 681-688) en donde se alude genéricamente a las "ciudades de Europa" (Europae ... urbes), de modo que el espacio geográfico queda también definido por el hecho de que sus habitantes se agrupan, de manera característica, en espacios articulados más allá de las aldeas o de los pueblos, es decir, en ciudades:

nec Pallas spectare potest, uoltusque gelassent

Perseos auersi, si non Tritonia densos

sparsisset crines texissetque ora colubris.

aliger in caelum sic rapta Gorgone fugit.

ille quidem pensabat iter propiusque secabat

aera, si medias Europae scinderet urbes:

Pallas frugiferas iussit non laedere terras

et parci populis.

INi Palas siquiera puede mirarla, y habrían helado el rostro

de Perseo, aun de espaldas a ella, si la Tritonia no hubiese esparcido

a Medusa los densos cabellos y cubierto la cara con las culebras.

Eliminada así Górgona, alado huyó al cielo.

Aquél acortaría su ruta y surcaría con menor rodeo

el aire, si cruzara por medio de las ciudades de Europa.

Palas, sin embargo, le ordenó que no contaminara las tierras fructíferas

y preservara a los humanos.] J.B.G.

${ }^{15}$ Los hispanos también son considerados europeos en Sil. Ital. Plun. I 220-221:

Altera complebant Hispanae castra cohortes, auxilia Europae genitoris parta tropaeis.

IUn segundo contingente lo conformaban las tropas hispanas, escuadrones auxiliares de Europa, fruto de las victorias de su padre.l.J. V. A. 
Frente a las virtudes que adornan a Europa, los otros continentes son, en otros lugares, caracterizados de modos bien diferentes. Así, Asia es - según el tópico amplísimamente extendido - tierra de lujo y molicie así como de hombres soberbios ${ }^{16}$ y afeminados, mientras que África/Libia, por su parte, lo es de desiertos, soles abrasadores y serpientes terribles, de acuerdo, por ejemplo, con Luc. IX 869-874:

...quaeremus forsitan istas

serpentum terras: habet hoc solacia caelum:

uiuit adhuc aliquid. patriae non arua requiro

Europamque alios soles Asiamque uidentem:

qua te parte poli, qua te tellure reliqui,

Africa?

|...Tal vez añoremos estos

territorios de serpientes. Se encuentra en este clima un consuelo:

existen todavía seres vivos. No reclamo las campiñas de la patria

y Europa y Asia, que contemplan soles diferentes:

¿En qué parte del cielo, en qué tierra te abandoné,

África?...] J.B.G.

o con Silio Itálico Pun. I 189-200 (Aeolïs candens Austris et lampade Phoebi /aestifero Libye torretur subdita Cancro... $)^{17}$.

Es preciso señalar que esa Europa geográfica desempeña un papel muy relevante en los poetas latinos como referente generalizador y englobador de los pueblos que desde tiempos míticos y hasta los tiempos históricos se enfrentaron o pudieron enfrentarse a otros que, a su vez, quedan agrupados bajo la rúbrica de Asia ${ }^{18}$. Tales enfrentamientos se reducen a unos grandes ciclos, que enlazan los tiempos míticos con la contemporaneidad de los autores. Si la expedición de los Argonautas apenas podría representar el primero de tales ciclos"', la Guerra de Troya, sin embargo, es universalmente

${ }^{16}$ Asia es ferox, por cjemplo, en Sen. Ag: 203-206.

"Vid. infra Claud. 5 In Rufinum II 36-42 (anhelantis Lybiae).

${ }^{18}$ Sin embargo, la interpretación explícita de las Guerras Púnicas como un enfrentaniento entre Europa y África no sucle darse.

${ }^{19}$ Con dificultad se podría interpretar como testimonio de tal consideración un texto como el de Val. Fl. Arg. II 613-615:

immittitque ratem mediasque intervolat urbes qua brevibus furit aestus aquis Asiamque prementem effugit abruptis Europa immanior oris. 
considerada como el primer gran enfrentamiento entre ambos continentes. Y, aunque la explicación mítica del conflicto - como es bien sabido - se reduce de manera simplista a la recuperación del honor perdido por un monarca aqueo, subyace en la conciencia colectiva de Grecia y, quizás aún más, de Roma la convicción de que allí se luchó por la supremacía de uno de los dos continentes. Ilustran bien la visión que de la Guerra de Troya tenían los poetas latinos como enfrentamiento entre Europa y Asia pasajes como Prop. II, III 35-36:

olim mirabar, quod tanti ad Pergama belli

Europae atque Asiae causa puella fuit:

[Antaño admiraba cómo en Pérgamo de guerra tan grande entre Asia y Europa pudo ser la causa una joven.] A. A. E.

o como Verg. Aen. VII 212-227:

Dixerat, et dicta Ilioneus sic uoce secutus: 'rex, genus egregium Fauni, nec fluctibus actos atra subegit hiems uestris succedere terris, nec sidus regione uiae litusue fefellit: consilio hanc omnes animisque uolentibus urbem adferimur pulsi regnis, quae maxima quondam extremo ueniens sol aspiciebat Olympo. ab Ioue principium generis, Ioue Dardana pubes gaudet auo, rex ipse Iouis de gente suprema: Troius Aeneas tua nos ad limina misit. quanta per Idaeos saeuis effusa Mycenis tempestas ierit campos, quibus actus uterque Europae atque Asiae fatis concurrerit orbis,

IToma después el timón y pasa veloz en medio de ciudades por donde se embravece el mar con aguas poco profundas y Europa más agreste con sus acantilados huye de Asia que la oprime.] S. L. M.

Sin embargo, esa interpretación está explícita en Val. Flac. Arg: VIII 393-396:

...sat vellera Grais

et posse oblata componere virgine bellum.

quemque suas sinat ire domos nec Marte cruento

Europam atque Asiam prima haec committat Erinys.

[...A los griegos les basta con el vellocino y con poder solucionar una guerra devolviéndole a la joven. Que deje a cada uno regresar a su casa y que esta Erinia no sea la primera en enfrentar a Europa con Asia en una guerra cruenta.] S. L. M. 
audiit et si quem tellus extrema refuso

summouet Oceano et si quem extenta plagarum

quattuor in medio dirimit plaga solis iniqui.

[Había dicho y lo dicho así Ilioneo siguió con su voz:

"Rey, linaje egregio de Fauno, ni por olas llevados

negro invierno nos obligó a alcanzar vuestras tieerras,

ni astro o costa erraron la dirección de nuestro camino:

todos con decisión y ánimos conscientes a esta ciudad

nos dirigimos, echados de reinos, los mayores antaño

que el sol contemplaba desde el Olimpo extremo viniendo.

De Jove nuestra raza empieza, la dárdana prole de Jove

su abuelo se goza, y el rey es de la alta estirpe de Jove:

Eneas troyano a tus umbrales nos ha hecho venir.

Cuán gran desgracia, nacida de Micenas cruel, por los campos

del Ida llegó, por qué hados uno y otro movidos

los mundos de Europa y de Asia, se vieron de frente,

lo oyó incluso aquél que la tierra última con Océano inverso

aleja y aquél a quien separa del sol inicuo la zona,

que en medio de las otras cuatro zonas se extiende.] A. A. E.

Y, tras esos, otros como en el propio Virgilio, Aen. X 87-91; y en Ovid. Am. II, XII (XIII) 17-18; Sen. Tro. 896-898; $A g$. 203-206; Ag. 273-274, y, con mayor insistencia aún, Stat. Ach. I 80-83; Ach. I 397-411; Ach. I 728-730; Ach. I 785-788; Ach. II 60-65.

Como es lógico, también las Guerras Médicas reciben esa lectura, aunque con menor intensidad que entre los autores griegos. En Lucano (II 672-677) hay un pasaje que evoca ese conflicto en clave de enfrentamiento entre Europa y Asia:

talis fama canit tumidum super aequora Persen

construxisse uias, multum cum pontibus ausis

Europamque Asiae Sestonque admouit Abydo

incessitque fretum rapidi super Hellesponti,

non Eurum Zephyrumque timens, cum uela ratisque

in medium deferret Athon.

[De tal forma, cuenta la tradición, el arrogante Persa construyó caminos sobre los mares, cuando con osados puentes

allegó Europa a Asia y Sesto a Abido

y marchó sobre el turbulento estrecho del Helesponto

sin temor al Euro ni al Céfiro, mientras dirigía sus velas'y navíos

a través del Atos.] J.B.G. 
Por último, incluso las Guerras Civiles que sacudieron a Roma a mediados del s. I a. C., son en ocasiones interpretadas como enfrentamientos entre las partes del mundo ${ }^{20}$, de acuerdo con pasajes como éste de Luc. VI 812-818:

tu fatum ne quaere tuum: cognoscere Parcae me reticente dabunt; tibi certior omnia uates ipse canet Siculis genitor Pompeius in aruis, ille quoque incertus quo te uocet, unde repellat, quas iubeat uitare plagas, quae sidera mundi.

Europam, miseri, Libyamque Asiamque timete: distribuit tumulos uestris fortuna triumphis.

[Tú no preguntes por tu destino: las Parcas te lo darán a conocer aunque me calle; a ti un profeta más certero todo te lo vaticinará, tu propio padre Pompeyo, en los campos de Sicilia, también él sin saber adónde dirigirte, de dónde alejarte, qué regiones, qué estrellas del mundo ordenarte evitar. A Europa, desventurados, y a Libia y a Asia temed:

Fortuna ha repartido vuestras tumbas en las regiones de vuestros triunfos.] J.B.G.

o como éste otro de Mart. Epigr. V, LXXIV:

Pompeios iuvenes Asia atque Europa, sed ipsum

Terra tegit Libyes, si tamen ulla tegit.

Quid mirum toto si spargitur orbe? Iacere

Uno non poterat tanta ruina loco.

${ }^{20}$ Es bien conocido que también las guerras entre Octavio y Marco Antonio fueron entendidas por el bando vencedor como guerras "externas", entre Roma y Egipto, entre Europa - Octavio - y Asia - Marco Antonio -, más que como guerras civiles. La bibliografía a este propósito es abundante. Vid., v. gr., A. Alvar Ezquerra, "La guerra como tema en la literatura latina", en Ideas. Conflicto, drama y literatura en el mundo antiguo (Ciclo de conferencias de la XLVIII edición del Festival de Teatro Clásico de Mérida), S. López Moreda (ed.), Madrid, Ed. Clásicas, 2003, p.13-51. En el pasaje del testamento político del emperador Augusto conservado en el Mon. Ancyr: (In templis omnium civitatium prlovincilae Asiae victor ornamenta reposui, quae spoliatis tem/plis isl, cum quo bellum gesseram, privatim possederat) parece leerse una interpretación de ese tipo. Vid. A. Alvar Ezquerra, "De nuevo sobre Cornelio Galo: a propósito de la fecha de composición de los versos de PQasr Ibrîm inv. 78-3-11/1", Actas del VII Congreso Español de Estudios Clásicos, Madrid, Univ. Complutense, 1989, p.4.43-4.49. 
[Asia y Europa cubren a los jóvenes Pompeyos; a Pompeyo mismo, en cambio, la tierra de Libia, si es que lo cubre alguna. ¿Qué tiene de extraño que estén dispersos por el orbe entero? Tan gran ruina no podía yacer en un solo lugar.] D. E. A.

\section{Europa ¿una idea?}

Europa, incluso como palabra, desaparece de la poesía latina entre el s. II y el s. V. No sólo desaparece de la escasísima poesía conservada hasta principios del s. IV, sino que incluso brilla por su ausencia en un poeta tan prolífico y polifacético como Ausonio. Sin embargo, Europa vuelve a aparecer con vigor en dos poetas del s. V, Claudiano y Sidonio Apolinar. Ahora ya Europa se ha despojado definitivamente de su acepción mítica y de las derivadas de ella; Europa se va configurando como un espacio amplio equivalente al Imperio romano de Occidente y quizás aún mayor. Es cierto que no hay una simetría entre las dos divisiones imperiales y las partes del mundo: la línea divisoria de las partes del Imperio cruzaba la Península balcánica al Norte del Mediterráneo y cortaba en dos los desiertos de Libia, de acuerdo con la anterior división provincial. Pero no es menos cierto que, por quedar la mayor parte del Imperio romano de Oriente en territorio asiático resultaba casi necesaria la identificación de cada una de las partes del Imperio con cada uno de los dos continentes. Léanse varios textos de Claudiano; por ejemplo, Claud. 5 In Rufinum II 36-42:

$$
\begin{aligned}
& \text { hinc planctus Asiae; Geticis Europa cateruis } \\
& \text { ludibrio praedaeque datur frondentis ad usque } \\
& \text { Dalmatiae fines: omnis quae mobile Ponti } \\
& \text { aequor et Hadriacas tellus interiacet undas } \\
& \text { squalet inops pecudum, nullis habitata colonis, } \\
& \text { instar anhelantis Libyae, quae torrida semper } \\
& \text { solibus humano nescit mansuescere cultu. }
\end{aligned}
$$

[Enseguida se oye el lamento de Asia; Europa, hasta los límites de la frondosa Dalmacia, es entregada a las hordas de los getas para diversión y botín. Toda la tierra que se extiende entre la mudable llanura del Ponto y las aguas de Adriático palidece desprovista de ganados, no habitada por colono alguno, a semejanza de la jadeante Libia que, abrasada siempre por el sol, ignora el suavizarse con los cultivos de los hombres.] M. C. B. 
donde Europa se complementa con Asia (Occidente con Oriente) tanto como en Claud. 15 In Gildonem 1-5':

Redditus imperiis Auster subiectaque rursus

alterius conuexa poli. rectore sub uno

conspirat geminus frenis communibus orbis.

iunximus Europen Libyae. concordia fratrum

plena redit.

[El sur ha sido restituido al imperio y la bóveda del otro cielo ha sido de nuevo sometida. Las dos partes del mundo se unen con riendas comunes bajo un mismo gobernante. Hemos unido Europa a Libia. Vuelve plenamente la concordia de los dos hermaṇos.] M. C. B.

lo hace con África/Libia (Norte con Sur) ${ }^{22}$.

"Otro pasaje ilustrativo de esa rivalidad complementaria se lee en Claud. 21 De consulatu Stilichonis I 84-88:

tunc et Solis equos, tunc exultasse choreis

astra ferunt mellisque lacus et flumina lactis

erupisse solo, cum floribus aequora uernis

Bosporos indueret roseisque euincta coronis

certantes Asiae taedas Europa leuaret.

[Cuentan que entonces los caballos del Sol, que entonces los astros danzaron de alegría en coros y que brotaron del suelo manantiales de miel y arroyos de leche, mientras el Bósforo adornaba sus aguas con flores primaverales y Europa, coronada con guirnaldas de rosas, levantaba las antorchas rivalizando con Asia.l M. C. B.

${ }^{22}$ Vid. otro ejemplo en Claud. 24 De consulatu Stilichonis III 280-282:

dum nos horribiles Libyae scrutamur alumnos,

Europae nos interea perquirite saltus et scopulos.

[Mientras nosotras rastreamos la espantosa progenie de Libia, vosotras entretanto registrad las sclvas y roquedales de Europa.] M. C. B.

Por último, Claud. 28 Panegyricus dictus Honorio Augusto VI cos. 101-104:

felix ille parens, qui te securus Olympum

succedente petit! quam laetus ab aethere cernit

se factis creuisse tuis! duo namque fuere

Europae Libyaeque hostes: Maurusius Atlans

Gildonis furias, Alaricum barbara Peuce

nutrierat... 
Sin embargo, Europa se nos presenta aún más encerrada en sí misma y en su destino en Sidonio Apolinar. Se diría que, tras despojarse de los aditamentos míticos, necesita ya librarse de la eterna confrontación con Asia y con Libia para ser, por fin, ella misma. Salvo en Sid. Apol. II Pan. 46-49:

\section{At tu circumflua ponto}

Europae atque Asiae commissam carpis utrimque temperiem; nam Bistonios Aquilones hiatos proxima Calchidici sensim tuba temperat Euri.

[Tú, bañada por los mares de Europa y de Asia, adoptas el clima que te confían ambos continentes, porque la cercana trompeta del euro calcídico templa sensiblemente el soplo del aquilón de la Bistonia.] A. L. K.

en que, de nuevo, aparecen hermanadas Europa y Asia, en los demás casos, Europa camina ya sola hacia su propio destino. Véanse, a este propósito, Sid. Apol. V Pan. 1-9:

Concipe praeteritos, respublica, mente triumphos:

imperium iam consul habet, quem purpura non plus

quam lorica operit, cuius diademata frontem

non luxu sed lege tegunt, meritisque laborum post palmam palmata venit; decora omnia regni accumulant fasces et princeps consule crescit. Personat ergo tuum caelo, rure, urbibus, undis exultans Europa sophos, quod rector haberis, uictor qui fueras.

[Trae a la memoria, oh república, tus triunfos pasados: ya tiene el-imperio un cónsul . cubierto con la coraza más que con la púrpura, cuya frente ciñen diademas, más que de lujo, de legalidad, y cuya toga, adornada de palmas tras la victoria, viene a coronar los méritos de sus trabajos. Los haces se suman a todos los honores del poder y el emperador gana en estatura al ser cónsul. Por eso resuenan en el cielo, el campo, las ciudades y los mares, los vítores que Europa te dedica, exultante por tenerte como guía a ti, que habías sido ya su vencedor.] A. L. K.

I;Dichoso aquel padre tuyo que, al sucederle tú, entró en el Olimpo despreocupado del futuro! ¡Cuán alegre contempla desde el cielo su crecimiento por tuis hazañas! Pues Europa y Libia tuvieron dos enemigos: el mauritano Atlas había nutrido la furia de Gildón, la salvaje Peuce a Alarico.] M. C. B. 
o Sid. Apol. V Pan. 203-207:

Quid faciam infelix? Nato quae regna parabo

exclusa sceptris Geticis, respublica si me

praeterit et paruus super hoc Gaudentius huius

calcatur fatis? Istum iam Gallia laudat

quodque per Europam est.

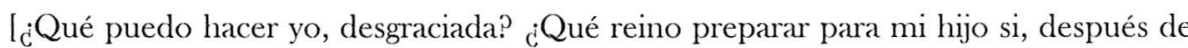
ser excluida del trono visigótico, me ignora la república y nuestro pequeño Gaudencio es conculcado por el destino de Mayoriano? A éste le alaban ya la Galia y todas las provincias de Europa...] A. L. K.

A la luz de estos testimonios, no resulta aventurado concluir que Europa ya no es en esos momentos una referencia mítica sino un espacio geográfico, una realidad física. Como consecuencia de la fragmentación y de las pérdidas territoriales (Imperio de Oriente, África en manos de los vándalos) y de las mezclas de pueblos bárbaros y romanos, Europa se va perfilando poco a poco como un espacio con identidad propia.

\section{Conclusiones}

Europa es una presencia constante y polivalente en la poesía latina. Mas, si bien se reconoce que el espacio geográfico debe su nombre a la joven sidonia raptada por un toro y llevada a Creta, al final del a Antigüedad esa joven ha dejado de ser referencia y Europa se reconoce ya tan sólo como espacio geográfico.

Sin embargo, Europa, como tal espacio geográfico, no ha conseguido convertirse, en los largos siglos de la Antigüedad y en el imaginario de los poetas latinos, en un espacio cultural coherente y bien identificado. Ni los textos de Lucano o Manilio en el s. I d. C., ni los de Claudiano y Sidonio Apolinar en el s. V permiten entrever nada que pueda sustituir a la idea de Roma, como espacio cultural, político, social y civilizador; mas esa idea parece ir perfilándose primero en opisición a Asia y a África, luego por sí misma. Europa, al final de la Antigüedad, en las vísperas de la desaparición del Imperio romano de Occidente, es aún una idea posible pero apenas real. 


\title{
FUNCIÓN DE LOS EXEMPLA EN VALERIO MÁXIMO \\ Y SU PERVIVENCIA EN LA EDAD MEDIA Y RENACIMIENTO
}

\author{
Santiago López Moreda \\ (Universidad de Extremadura)
}

\begin{abstract}
The literature dealing with old sayings, especially that resorting to exempla, found a plentiful source for the teaching of moral virtues in the deeds and memorable quotations of Valerius Maximus. During the Middle Ages and the Renaissance the figure of the Roman rhetor-historian played a pivotal role within the field of favourite authors. However, as time went by, it was gradually replaced by Chriastian and national models, and the exemplum, owing to its own success, caught on so much so that its independent use was a source of delight and, consequently, it was censored by Erasmus and abolished by successive councils.
\end{abstract}

\section{INTRODUCCIÓN}

La literatura paremiológica, bajo sus diferentes formas (apólogo, fábula, cuento, parábola, refranero, apotegmas, ejemplos), aunque no llegó a ganarse un puesto en el catálogo de géneros literarios en las poéticas clásicas, por sus connotaciones didácticas y persuasivas se mantuvo viva en todas las épocas y literaturas nacionales.

A diferencia de la fábula y el cuento, que circularon de manera autónoma, el ejemplo nunca dejó de ser un compañero servil de otros géneros literarios y de cumplir una función subsidiaria. No existe el género literario del "ejemplo", ni una "literatura de los ejemplos" y, sin embargo, los Hechos y dichos memorables de Valerio Máximo se mantuvieron vivos en la tradición literaria y escolar durante más de quince siglos, con tanta o mayor fortuna que 
las obras de historiadores consagrados como César, Salustio, Livio o Tácito, y ello pese al mínimo reconocimiento, cuando no el descrédito, que las diferentes monografías de literatura latina le dan al incluir a Valerio Máximo en el corpus de historiadores.

La contradicción, cierta, entre los historiadores de la literatura latina y la pervivencia de nuestro autor es fruto de un enfoque erróneo nacido de la propia esencia de las poéticas clásicas, especialmente las de Aristóteles y Horacio. Al basarse en criterios formales más que en los de contenido para clasificar géneros literarios, los géneros en prosa salen lógicamente malparados, máxime cuando el único que tiene cierta autonomía es el de la historiografía y siempre en contraposición a la poesía épica, sobre todo en Aristóteles.

$\mathrm{Al}$ ser la historia una narración de hechos pasados sin quebrantar la lex veritatis, ante la evidencia de muchos ejemplos que se pierden en los tiempos, que ofrecen escasa credibilidad o que no llegan ni siquiera a ser verosímiles, enjuiciar a Valerio máximo como historiador conduce inevitablemente a valorarlo como autor de segunda fila. $\mathrm{Y}$ es aquí donde nace, a nuestro entender, el gran error de apreciación y el descrédito consiguiente.

Pero, como decíamos líneas atrás, Valerio Máximo vive con buena salud más de quince siglos y ello nos obliga a entender y justificar la razón de esta pervivencia, que no es otra que el análisis de sus más de 900 exempla para saber las razones que mantuvieron dicha pervivencia; en otras palabras, hallar las líneas directrices del corpus, el denominador común que comparten los exempla, para tener validez en tan diferentes sistemas políticos, ámbitos geográficos y programas educativos tan dispares.

\section{Quod proprie vocamus exemplum.}

El exemplum en su esencia es de una lógica muy sencilla: si en una 40 situación determinada se produce un comportamiento $\mathrm{X}$, al repetirse esa situación, se volverá a repetir el comportamiento. Es importante saber lo que sucedió para evitarlo, en caso negativo, o reproducirlo, en caso positivo'. El comportamiento de hechos o palabras de los antiguos nos servirá de modelo a los modernos. Por eso, el ejemplo, como primera connotación, se basa en un

\footnotetext{
'Quintiliano es bien explícito al señalar: omnis vitae ratio sic constat, ut quae probamus in aliis, faccre ipsi velimus (Inst. X 2, 2).
} 
hecho de experiencia, responde al mos maiorum y puede fijar un código de conducta previo a la ley. Al margen del tiempo, el ejemplo establece un código de virtudes propias de un ciudadano en un sistema político determinado, democrático o no. Así en una sociedad heroica predominarán los ejemplos individualistas, pero en una sociedad monárquica (Tiberio), se abandonan los comportamientos heroicos individualistas, la moral épica no tiene cabida en el Imperio y ya desde la Eneida se nos presenta a un héroe al servicio de la colectividad.

En consonancia con lo hasta aquí expuesto cabe una serie de preguntas como ¿por qué ahora aparece la primera codificación de exempla en la literatura latina? $?^{2}$ ¿qué pretenden todos ellos en su conjunto, si es que hay algún hilo conductor?, ¿por qué perviven a lo largo de tantos siglos?

Una simple ojeada a las definiciones de exemplum que ofrecemos a continuación nos lleva de inmediato a observar que todas ellas tienen que ver con la retórica, la oratoria y la enseñanza gramatical (Retórica a Herenio, Cicerón, Quintiliano, Donato, Carisio y Diomedes) y que básicamente coinciden en una serie de puntos:

1. La referencia a algo pasado (alicuius facti aut dicti praeteriti; antiquitátis). Ejemplos 1 y 2.

2. El basarse en un hecho o un dicho (facti aut dicti; factorum quam dictorum). Ejemplos 1 y 7.

3. Confirmar o anular una prueba basándose en la autoridad del sujeto (confirmat aut infirmat; hortantis aut deterrentis; hortationem dehortationemve; adhortationem vel dehortationem). Ejemplos 3, 8, 9 y 10.

4. Incluso siendo inventados, pueden tener fuerza probatoria (ficta; rei gestae aut ut gestae). Ejemplos 4 y 6 .

5. Es un recurso ornamental del discurso por lo que Cicerón termina por adscribirlo a la elocutio (ornamentum orationis). Ejemplo 5.

1.1. Exemplum est alicuius facti aut dicti praeteriti cum certi auctoris nomine propositio. Id sumitur isdem de causis, quibus

"Tal vez sea así porque no nos han llegado las obras de Higino y Nepote sobre el particular, aunque no es descartable la existencia de colecciones que pudieron circular en el ámbito docente para uso de los réctores. Cf. G. MASLAKOV, «Valerius Maximus and Roman Historiography. A Study of the Exempla Tradition", $A N R W 2$, 32, 1, Berlín, Nueva York, 1984, p.457; C. BOSCH, Die Quellen des Valerius Maximus, Stuttgart, 1929. 
similitudo. Rem ornatiorem facit, cum nullius rei nisi dignitatis causa sumitur; apertiorem, cum id, quod sit obscurius, magis dilucidum redit; probabiliorem, cum magis veri similem facit; ante oculos ponit, cum exprimit omnia perspicue, ut res prope dicam manu temptari possit (Ret. a Herenio, IV, 49).

«El ejemplo consiste en citar un hecho o dicho pasado con el nombre concreto del autor. Se emplea por las mismas razones que la comparación. Da más brillo a la idea cuando se utiliza sencillamente por belleza formal; la hace más lúcida cuando clarifica lo que estaba algo oscuro; más plausible cuando le confiere verosimilitud; pone las cosas ante los ojos cuando expresa todo tan vivamente que casi podríamos decir que puede tocarse con la mano".

1.2. Commemoratio autem antiquitatis exemplorumque prolatio summa cum delectatione et auctoritatem orationi adfert et fidem. (Cic., Orator, 120)

"Conmemorar, pues, la antigüedad y aportar ejemplos confiere al discurso autoridad y credibilidad a la vez que el mayor deleite».

1.3. Exemplum est quod rem auctoritate aut casu alicuius hominis aut negotii confirmat aut infirmat. Horum exempla et descriptiones in praeceptis elocutionis cognoscentur (Cic., De inv. 1, 49).

«El ejemplo es lo que confirma o anula una prueba basándose en la autoridad o el suceso de un hombre o de un asunto. Ejemplos y descripciones de lo que digo se verán en los preceptos de la elocution.

1.4. Ex eodem similitudinis loco etiam exempla summuntur (...) Quae commemoratio exemplorum valuit, eaque vos in respondendo uti multum soletis. Ficta enim exempla similitudinis habent vim (Cic. Topica, 44-45).

«Del tópico de la similitud también se extraen ejemplos (...) Este recurso de recordar ejemplos tiene valor y vosotros acostumbráis a serviros frecuentemente de él en las respuestas. Incluso los ejemplos inventados tienen la fuerza probatoria de la similitud». 
1.5. Morum ac vitae imitatio vel in personis vel sine illis, magnum quoddam ornamentum orationis et aptum ad animos conciliandos vel maxime, saepe autem etiam ad commovendos; personarum ficta inductio vel gravissimum lumen augendi (Cic., De orat. III, 204$-205)$.

«Plasmar las costumbres y la vida, tanto valiéndose de personas como sin ellas, es un gran recurso ornamental del discurso, y sirve para disponer a favor los ánimos y a menudo, incluso para conmoverlos. Hacer aparecer un personaje supuesto es la figura más adecuada para la amplificación».

1.6. Rei gestae aut ut gestae utilis ad persuadendum id quod intenderis commemoratio. (Quint. Inst. V 11, 6).

«Traer a colación un hecho pasado real o ficticio es útil para persuadir de algo que pretendes».

1.7. Tam factorum quam dictorum ratio est (Quint. Inst., I 9,6).

«Da cuenta tanto de hechos como de dichos».

1.8. Paradigma est narratio exempli hortantis aut deterrentis (Don., Gramm. III, vi (GLK, I, 402, 28-29).

«El paradigma es la narración de un ejemplo que aconseja o desaprueba algo»

1.9. Paradigma est rei praeteritae relatio ad hortationem dehortationemue (Car., Ars Gramm. III, ii (GL, III, 277, 16-17).

«El paradigma es el relato de una cosa pasada para aprobar o desaprobar».

1.10. Paradigma est enarratio exempli uel rei praeteritae relatio significans adhortationem uel dehortationem (Diom., Ars Gramm. II (GLK, I, 464, 17-18).

«El paradigma es la narración de un ejemplo o el relato de algo pasado para aprobar o desaprobar».

En la cultura latina aparece como una expresión típica de las costumbres romanas (mores) en la educación de los primeros tiempos y como forma de 
transmitir un sistema de valores independientemente de la filosofía y de la retórica griegas cuando éstas aún no habían hecho acto de presencia en Roma. Recuérdense la costumbre de los grassatores y de los carmina convivalia en que se propagaban gestas y ejemplos de antepasados ilustres, como nos dice Catón, para despertar el sentido de emulación entre los jóvenes romanos ${ }^{3}$.

Con el desarrollo de los conflictos políticos y los procesos judiciales, especialmente en los dos últimos siglos de la república, la aceptación de la retórica de procedencia helénica fue una auténtica necesidad que afectó a la práctica totalidad de la literatura romana, y si bien el ejemplo se mantuvo en el ámbito familiar y escolar como medio de transmitir valores educativos, se incorporó también a los procedimientos retóricos para la persuasión. Cuando Aristóteles habla de ésta en su Retórica, distingue bien entre los argumentos puramente técnicos, las pruebas (písteis), y los procedimientos persuasivos pensados para los jueces y basados más en la emotividad y el pathos.

Las pruebas que no pertenecen a los hechos y que se presentan fundamentalmente para persuadir, corresponden sobre todo al discurso deliberativo: «Se deben usar los ejemplos cuando no se tienen entimemas para la demostración o bien colocarlos tras los entimemas utilizándolos como testimonios - afirma Aristóteles»".

En la Retórica a Herenio el ejemplo encuentra su sitio en la elocutio y no en la inventio o en la dispositio. Cicerón terminará por aceptar que los ejemplos son los que otorgan credibilidad a una argumentación.

La categoría del éthos (mos) al incorporarse a la retórica adquirió rango de tópos (lugar común) y la autoridad del emisor pasó al receptor precisamente por el aval de dicho éthos. Las laudationes fúnebres y los carmina eran manifestaciones claras de lo que decimos, y su consecuencia más inmediata fue la concepción de una historia pragmática de la ejemplaridad, tal como la enunció Cicerón y puso en práctica Tito Livio.

El ejemplo, pues, se introdujo en la historiografía bajo la forma de biografía, pero acotando aún más el contenido, ya que se trata de una pequeña historia, corta, que se refiere al pasado de la vida de un gran personaje, por lo

\footnotetext{
${ }^{3}$ NEVIO ZORZETTI, «L'exemplum nel ragionamento induttivo e nella comunicazione", MEFRM 92 (1980), 1, p.43.

'ARistóteles, Retórica II 20, 9.

' Retórica a Herenio IV 4.9.

'La expresión exempla fidem faciunt se convierte ya desde él en proverbial (EI orador; 120).
} 
general, para justificar una doctrina o un principio moral, que en el caso de Valerio Máximo es el propuesto en el encabezamiento del libro o capítulo correspondiente.

Cicerón; en De inventione aconseja valerse del exemplum como recurso en la confirmatio y cuando en los últimos años escribe el De oratore, evoca también su uso como elemento del ornato: «La plasmación de las costumbres y de la vida, tanto valiéndose de personas como sin ellas, es un gran recurso ornamental del discurso, y sirve para disponer a favor los ánimos y a menudo, incluso para conmoverlos»?

Por esta razón, quienes niegan a Valerio Máximo rigor histórico, sencillamente ignoran que estamos ante un rétor profesional que no escribe una monografía (Salustio y César) o una historia general (Livio), sino una colectanea de más de 900 ejemplos tomados del mundo romano y extranjero «a fin de que puedan ser conocidos de manera inmediata y así les cueste poco esfuerzo a quienes quieran consultar las fuentes", como señala en el prefacio de su obra.

Estamos, pues, ante un vademécum de exempla que sirven para otros fines, que los meramente histórico-divulgativos. Prestan más servicio a la Retórica que a la Historia; de ahí que el deleite, la autoridad y la credibilidad constituyan en esencia las tres razones de ser del ejemplo.

Lo peculiar del ejemplo en Valerio Máximo es que sigue un esquema narrativo simple que lo hace a la vez sumamente propicio para la labor educadora.

En su esencia, el ejemplo consta de tres elementos:

— presentación del personaje o anécdota;

— relato de un hecho;

- reflexión conclusiva.

Su valor convincente, por la claridad, es superior al de la fábula y la parábola, formas estrechamente ligadas ya en Aristóteles. No en vano, el ejemplo se basa en hechos tenidos por ciertos, mientras que la parábola y la fábula se mueven en el terreno de la ficción y a menudo requieren de una explicación o moraleja que resuma el objetivo de ambas formas.

El ejemplo, además, es sumamente fructífero y conveniente para el conocimiento de los hechos, siempre que reúna las siguientes propiedades,

' Ciclerón, Del orador III 204-205. 
algunas apuntadas ya en Cicerón y Livio, y todas ellas sistematizadas recientemente por Suleiman":

Univocidad, para imponer al lector una verdad moral exenta de interpretaciones múltiples.

Brevedad, para ser más fácilmente aprehensible, aunque con el paso del tiempo surgieran defensores de la amplificatio, como ocurre en el siglo XVI con Erasmo y Hieronymus Regius, entre otros".

Autenticidad, que se logra por la autoridad del personaje de quien se extrae, lo que implica la aceptación del proceso comunicativo entre el emisor y el receptor.

Verosimilitud, para ser creído.

Placer, tal como señalaba ya Cicerón: «pues los ejemplos relativos a los tiempos primitivos, recuerdos literarios y tradición escrita confieren más autoridad a la prueba y más placer al oyente".".

Capacidad de perdurar en la memoria, por el valor que la imagen formada evoca.

Sin duda, fueron éstas las propiedades que hicieron penetrar el ejemplo y la imagen en otros campos artísticos sobrepasando la retórica y la historia. Plinio habla de estatuaria histórica, mitológica y de pintura" y el propio Valerio Máximo recuerda la escultura de Lucio Escipión vestido con clámide y calzando sandalias porque había introducido modas poco adecuadas a las costumbres romanas ${ }^{12}$. La descripción de Quinto Metelo recuerda perfectamente lo que eran los tituli imaginum al repasar toda la biografía del noble «desde el primer día de su nacimiento hasta el momento mismo de morir»"3.

"Cic., Verr. 3, 209; Liv., I 46, 3 pref. 10; S. SULEIMAN «Le Récit exemplaire. Parabole, fable, roman à thèse", Poétique 32 (1997), 475.

"Erasmo añade unos modi locupletandi exempla a su De duplici copia rerum ac verborum. Y Jerónimo Regio escribe De amplificanda oratione, apud linguae Latinae commentaï tres (1554), BNM, R-33977.

${ }^{10}$ Ciclirón, Discursos contra Verres, II 3,209. También Livio en I 46, 3, pref. 10, y recientemente S. Sulfiman, "Le Récit exemplaire. Parabole, fable, roman à thèse», Poétique 32 (1997), 475.

"Pinni(), Historia Natural XXXIII 26-29.

${ }^{12}$ III 6, 2.

"VII 1, 1. 
Más adelante volveremos sobre ello al tratar de la pervivencia de Valerio Máximo; ahora baste sólo con añadir que la rentabilidad de esta práctica del ejemplo penetró de tal manera en los programas educativos que las artes predicatorias medievales toman los ejemplos, reales o ficticios, de la vida de los santos padres, de los mártires y de los santos a modo y semejanza de los grandes personajes romanos".

Las posibles objeciones que pudieran plantearse, tales como la memoria colectiva frente al consenso moral, la narración de algo pasado frente a la respuesta emocional de los lectores y oyentes vivos, o la personalidad y credibilidad del historiador frente a la receptividad del lector, se solventaban con la autoridad moral del pasado y la pervivencia de las virtudes o el rechazo de los vicios, tanto en el momento de producirse el ejemplo como en el momento de difundirse el mismo, es decir, con la pervivencia de un código de valores morales, tales como los deberes para con los dioses y para con los hombres.

Los ejemplos de Valerio Máximo se insertan, pues, en la línea moralista que recorre toda la historiografía latina desde Salustio y que la escuela, siempre, y el Cristianismo, tras su aparición, se encargaron de mantener y propagar.

Valerio Máximo, además, como buen analista de la condición humana, y en consonancia con la mentalidad y sociedad multinacional de un imperio, abrió el espectro de las fuentes y supo ver también virtudes en extranjeros, esclavos, mujeres y hasta en los niños. ${ }^{15}$. Que muchos de estos ejemplos puedan ser sospechosos de faltar al rigor histórico importa poco si consideramos la historiografía antigua como un género literario y no como una ciencia. Tal vez sea también ésta la razón por la que la categoría del tiempo no cuenta; el relato histórico no viene dado por la sucesión cronológica, es intemporal, como ocurría en Varrón, e incluso hay una especie de fuga del presente, por lo triste de la situación, para rememorar épocas más gloriosas y ejemplares.

"Cf. JACQUes Berlioz, "L' exemplum au service de la prédication", en J. BlRLiIOZ et J. M. Davin, Rhétorique et Histoire. L'exemplum et le modèle de comportement dans le discours antique et médiéval. Ménages de l' École Française de Rome, París 1980, 113-146.

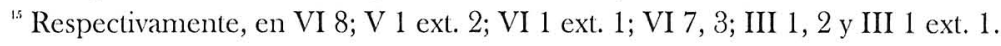




\section{Virtudes y vicios. De la retórica a la historiografía}

Básicamente, los ejemplos se insertan dentro del marco de las cuatro virtudes cardinales tal como apreciamos en el esquema siguiente:

Valerio Máximo

1. sapientia (sabiduría)

2. iustitia (justicia)

3. fortitudo (fortaleza)

4. temperantia (templanza)

\section{Cicerón}

prudentia

iustitia

fortitudo

temperantia

La única novedad consiste en que Cicerón denomina prudentia a la sapientia (De inv. II 159); pero en II 160 la define de manera equivalente: «ciencia o conocimiento de lo que es bueno, lo que es malo y lo que no es ni bueno ni malo». Más tarde, con el paso del tiempo, el Arpinate termina reduciendo estas cuatro, virtudes a sólo dos: la scientia, que comprende la sapientia, y la temperantia, que comprende a las otras tres. A manera de colofón, la moderación (verecundia) es el guardián de todas ellas.

Tal disposición no hace sino confirmar que, al coincidir con Cicerón, que trata de estas virtudes en los loci communes para los discursos políticos y los elogios, Valerio Máximo concibe su obra como un tratado técnico que sirve para el genus demonstrativum, tanto con el significado de «sacar a la luz» y «elogiar» a determinados personajes y acontecimientos históricos, como en el sentido de «demostrar» una serie de argumentaciones.

En el análisis de sus exempla podemos observar dos intenciones:

- la operatividad de los mismos como vademécum de rétores y alumnos;

- el juicio histórico que en tiempos de Tiberio merecieron los acontecimientos y personajes más importantes de la Historia.

En el cuadro general de las virtudes romanas, siguiendo las normas retóricas de la invención y la disposición, hay una jerarquía claramente establecida que se corresponde con el orden expositivo: la virtud más relevante es la justicia, porque radica en la propia naturaleza humana ${ }^{16}$ y porque regula las

"Ciclerón, De inv. II 160: «Su naturaleza radica en que no nace de la opinión, sino que está inserta en la propia naturaleza humana». 
relaciones entre los dioses y los hombres (religio) y las de los hombres entre sí. Su importancia explica que esté presente en los libros I, II, VI y IX. Y como quiera que los dioses se manifiestan mediante presagios, prodigios, sueños y milagros, a todas estas manifestaciones dedica el libro I. Los ejemplos criticados por los historiadores por ser escasamente científicos, han de ser enjuiciados desde esta perspectiva".

El libro II, mediante la amplificatio, desarrolla el contenido del libro I porque la justicia se asienta en la costumbre (mos), que a su vez hace nacer la ley (lex); de ahí la importancia que tiene la tradición moral y social. La intencionalidad política del tratamiento de esta virtud es evidente y de ella sacará partido a efectos propagandísticos, como veremos más adelante en los casos de personajes y comportamientos «revolucionarios y conservadores».

La fortaleza (fortitudo), que ocupa el lugar siguiente a la justicia en el cuadro general de las virtudes, da contenido al libro III y justifica el IV y V, ya que el posible exceso de la misma debe evitarse mediante la moderación. La fortaleza se manifiesta en la naturaleza individual (natura) y en las disposiciones naturales (indoles), lo que justifica la presencia en el relato de los más legendarios héroes romanos (Horacio Cocles, Porsena, Emilio Lépido, Catón el Viejo, Catón de Útica) y extranjeros (Leónidas), así como la de aquellos que demostraron una gran confianza en sí mismos o hicieron alarde de la constancia.

Los posibles riesgos de la excesiva fortaleza se corrigen con la moderación. Y si bien es cierto que cabría incluir esta virtud dentro de la templanza, Valerio Máximo le dedica nada menos que dos libros.

A nuestro entender hay al menos dos razones importantísimas para ello. La primera tiene que ver con la doctrina retórica: la moderación es la cuarta de las virtudes en la Retórica a Herenio ${ }^{18}$; la segunda razón apunta claramente hacia la intencionalidad política de la obrà: la invitación a la moderación del príncipe y de los ciudadanos, el elogio de la paz y la tranquilidad, la beatitudo y la tranquillitas.

${ }^{17}$ No se trata, pues, de quebrantar la fides histórica; los asuntos divinos requieren la fe, la autoridad de los dioses no se discute y la propia historiografía cristiana no discute el providencialismo, ni tampoco se cuestionan sucesos de la vida de los santos, por muy inverosímiles que parezcan.

${ }^{1 *}$ Retórica a Herenio III 2: "La templanza (modestia) es la moderación y continencia de las pasiones del alma». 
Valerio Máximo destaca los beneficios de esta virtud al contraponerla a los vicios en dos pares antitéticos: la abstinencia, que se opone a la pasión de marcado carácter sexual (libido) y la continencia, que se opone al deseo desmedido de todo tipo de bienes y placeres (cupiditas). La moderación, además, se manifiesta en la humanitas, en la pietas y en la clemencia, que son las virtudes singulares del buen gobernante (Tiberio) en contraposición a quienes no han sabido ser moderados (Sejano) y han sumado además el vicio de la ingratitud.

En cualquier caso, los ejemplos de quienes han hecho gala de esta virtud, tales como los de los antiguos nobles o de Catón de Útica, por citar algún caso, crean cierta tensión entre éstos y los que han obtenido el poder tras una serie de guerras civiles que propicia la llegada de los Julio-Claudios. Valerio Máximo resuelve esta tensión mediante el consenso de dioses y hombres de que habla en el prefacio, porque los Césares traen la regeneración moral (Augusto y Tiberio) y, sobre todo, la felicidad (beatitudo), la tranquilidad (tranquillitas) y seguridad de nuestro siglo, que Sejano quiso cortar con la conjuración del año 31 excediéndose en su poder (fortitudo). Esta es la razón por la que su ejemplo está expuesto en relación con los sucesos más desgraciados de la historia de Roma (Flavio Fimbria, Catilina) y de la historia foránea (dos hijos de un rey que se disputan la sucesión como vulgares gladiadores y Mitridates, que disputó la corona a su propio padre). De esta manera, mediante la antítesis habitual, contrapone los efectos de un poder desmedido a los beneficios que reporta el emperador, «artífice y defensor de nuestra incolumidad, que con su sabiduría divina impidió que se perdieran y desaparecieran, a la vez que todo el universo, los beneficios a nosotros concedidos»". El resultado no puede ser más brillante ni más explícito: "Permanece sólida la paz, siguen en vigor las leyes, se salvaguarda la santa religión de los deberes públicos y privados».

Nos parece igualmente sintomático que Valerio Máximo, a manera de epílogo, cierre toda la obra con las consideraciones anteriores que, por haber 50 sido tratadas en el libro IV, podían quedar olvidadas por el transcurso del relato. En dicho libro, al lado de la moderación, había tratado de la amistad y la liberalidad, y a ambas virtudes se refiere en el elaborado ejemplo de la deslealtad de Sejano. De esta manera, el historiador sintoniza con las ideas morales y políticas de Cicerón y Salustio.

${ }^{19}$ IX 11, ext. 4. Es muy llamativo que el ejemplo de Sejano, al que además no nombra, esté inserto entre los ejemplos extranjeros, lo que acentúa aún más el contraste. 
El Arpinate había definido la amistad como mutua benevolentia', Salustio como idem velle idem nolle". Esta idea, que en el caso de Cicerón recorre los tratados Sobre la amistad y Sobre los deberes, a efectos políticos le sirve para cerrar las heridas de las guerras civiles e invitar a la concordia, está presente de manera reiterada en Valerio Máximo porque le sirve, además, para consolidar el nuevo régimen ${ }^{22}$, ya que «no era conveniente que mantuviesen sus diferencias por rencillas privadas quienes estaban unidos por la más alta potestad ${ }^{23}$.

En el libro VI, al tratar de la templanza, la cuarta de las virtudes, sigue también las pautas marcadas por Cicerón ${ }^{21}$ y lo hace desde las múltiples manifestaciones de esta virtud, continencia, clemencia y modestia, para abundar en la fides y concluir con el fruto que acarrea la práctica de las virtudes: la felicidad, representada en la persona de Cecilio Metelo Macedónico, el más feliz entre los hombres y prototipo del nuevo canon de valores nobiliarios: "Quiso la Fortuna que Metelo naciese en la capital del mundo, le otorgó los padres más nobles, le confirió además unas excepcionales cualidades espirituales y una fortaleza física capaz de soportar las fatigas, le procuró una esposa célebre por su honestidad y fecundidad, le brindó el honor del consulado, la potestad generalicia y el lustre de un grandioso triunfo, le permitió ver al mismo tiempo a tres de sus hijos cónsules (uno de ellos también había sido censor y había recibido los honores del triunfo) y a un cuarto pretor; hizo que casara a sus tres hijas y acogiera en su mismo regazo a la descendencia de éstas...

En definitiva, tantos y tantos motivos de alegría; y en todo este tiempo, ningún duelo, ningún llanto, ningún motivo de tristeza. Contempla las moradas celestiales y difícilmente podrás encontrar allí un estado de dicha semejante» ${ }^{25}$.

La segunda intención buscada con el corpus de ejemplos es la de emitir un juicio histórico, el que en tiempos de Tiberio merecen los personajes y acontecimientos más importantes de la historia.

${ }^{20}$ Ciclirón, Sobre la amistad 7, 22.

"Saluistio, Catilina 20, 4.

"2 Valerio Máximo, IV 7 ext. 1; IV 7, 4; IV 7 ext. 2; V 5 prefacir.

${ }^{23}$ Y cita como ejemplos relevantes de concordia los de Marco Emilio Lépido y Fulvio Flaco, por un lado, y los de Livio Salinátor y C. Claudio Nerón, por otro: IV 2, 1 y 2 respectivamente.

${ }^{21}$ En el De inv. II 163 y 164.

${ }^{25}$ VII $1,1$. 
Valerio Máximo, a nuestro entender, de manera muy soterrada, al extraer sólo determinados rasgos del carácter de los personajes más relevantes, los verdaderos artífices de la historia según la concepción biográfica romana, a diferencia del análisis global que efectuaron Salustio o Tácito, más que hacer verdadera historia, lo que de verdad busca es celebrar la virtud y censurar el vicio supeditando los intereses particulares al bien público.

En las actuaciones políticas de los personajes parcialmente biografiados observamos la propuesta de un ideal de vida que responde básicamente a los objetivos heredados de Augusto y ratificados en la nueva literatura propagandística: la aurea mediocritas y la paz que garantiza Tiberio. Tranquillitas, pax y quies son los tres soportes sobre los que Valerio Máximo sustenta el reinado de Tiberio, y los tres están presentes en todos los momentos de la obra ${ }^{26}$.

Los hechos y dichos de todos los personajes son juzgados y valorados según los principios de la paz y la estabilidad. Así se explican los constantes alegatos contra la guerra, hasta el punto de que muchos personajes son considerados exclusivamente en función de su comportamiento para con la paz y el orden. Los casos de Mario, Sila, Pompeyo, César y Sejano son bien elocuentes. En realidad, Valerio Máximo no hace otra cosa que confirmar los sentimientos de toda una generación. Ovidio, lamentando la situación de la humanidad en la Edad de Hierro, se expresaba en estos términos: «Se vive de la rapiña; ni un huésped puede tener seguridad de su huésped, ni un suegro de su yerno; incluso entre hermanos es rara la avenencia ${ }^{27}$. Otro contemporáneo del historiador, Lucano, reiteradamente habla de la cognata acies para referirse a la guerra civil entre César y Pompeyo ${ }^{28}$; un poco más tarde, las fraternas acies de Estacio en la Tebaida recordaban el enfren-tamiento entre Eteocles y Polinices, pero evocaban al suegro y al yerno de la guerra civil por antonomasia, todavía reciente en buen número de escritores. Incluso a principios del siglo siguiente, Tácito, aunque lamentaba que en aras de la paz el poder hubiera pasado a manos de uno solo, encontraba cierto consuelo al afirmar que "tras la muerte de Bruto y Casio ya no hubo ejército republicano»". que tas la muerte de Brito y Casio ya no hubo jército republicanon.

" Para no hacer prolija la lista, pueden observarse los siguientes pasajes: I 1,10 y $11 ; \mathrm{I} 6$, 11 y 12; II 7, 5; III 1, 2; III 2, 17 y 18; III 8, 5; V 3, 2b; VI 3, 1c y 1d; VI 4, 1; VI 8, 3; VII 3, 9; VII 4, 3; VII 6, 1; VII 6, 4 y 5; VIII 6, 2; VIII 9,1 y 2; IX 2 , 1 y 2 ; IX 5 , 3 y 4; IX 7, 1-4; IX 11, 4. y 5 .

\footnotetext{
${ }^{27}$ Ovidio, Metamorfosis I 144-45.

${ }^{24}$ LiCAN(), Farsalia I 680, 694; VI 591-93; VII 872; IX 271.

${ }^{20}$ TÁcrto, Anales I 2.
} 
Estaba claro que se imponía una gradación de los valores ciudadanos a la vez que un nuevo concepto de libertad. Valerio Máximo otorga el lugar preeminente a la tranquillitas que sólo el emperador puede garantizar. Naturalmente, esta actitud doctrinal le lleva forzosamente a un planteamiento político: cuál es el papel que corresponde al príncipe y cuál debe ser la actitud de los ciudadanos para con el príncipe.

La respuesta viene dada por una sucesión de contrastes y una solución final. Los ejemplos que aluden a desastres y al pasado turbulento de Roma, en una visión sesgada y parcial de la historia nacional, son los más significativos. Al historiador sólo le interesan los ejemplos de inestabilidad y desorden, como los movimientos de los tribunos revolucionarios o de los Gracos, para que sirvan de contraste con la paz de Augusto y de Tiberio y para que los ciudadanos velen por el príncipe que les ha traído la paz. El pueblo, o mejor la plebe, y los líderes que, como Mario, Sila, Casio y Bruto, promovieron contiendas y enfrentamientos civiles, son las figuras negativas por excelencia. Mario, de quien reconoce y admira el rusticus rigor ${ }^{30}$, sólo es salvable en la medida en que viene a atenuar la crueldad de Sila.

No es otra la opinión de Veleyo Patérculo, para quien Mario fue «tan inmejorable en la guerra como pésimo para la paz».

Aunque Carney sostiene que Valerio Máximo, a diferencia de Tito Livio o Tácito, denota cierta inconsistencia al tratar los personajes ${ }^{31}$, en nuestra opinión no es así. En aras de la fidelidad histórica Valerio Máximo reconoce virtudes en los personajes de los que extrae ejemplos, al menos en algunas de sus actuaciones, pero el juicio último es coherente si lo analizamos desde los principios de la estabilidad y el orden. Si ocasionalmente trata bien a Mario ${ }^{32}$, es sólo porque ordenó encarcelar a Lucio Equicio que, despreciando las leyes, se presentaba como candidato al tribunado, o porque, comportándose como un buen ciudadano, fue útil a la república al reprimir las tentativas de Lucio Saturnino"; pero, "en medio de un banquete sostuvo entre sus manos, alegremente, la cabeza cortada de Marco Antonio. Sus victorias apenas tuvieron tanto valor, pues olvidándose de ellas mereció más reprobación en

${ }^{30}$ II 2,3

"T. F. CARneY, "The Picture of Marius in Valerius Maximus", RhM, 105 (1962), 289$-337$.

${ }^{32}$ Como en IX 7, 1.

${ }^{33}$ VIII 6, 2. 
tiempos de paz que gloria en tiempos de guerra»". Por encima de la valoración general está el ejemplo concreto que, a costa del rigor histórico, confiere más provecho moral y político.

Tras muchas alternativas y visiones parciales de los protagonistas de la primera guerra civil, en el libro noveno, el que supone un epílogo a su obra, es taxativo también a propósito de Sila: «Lucio Sila, a quien nadie puede alabar o vituperar suficientemente, porque, a los ojos del pueblo, fue un nuevo Escipión si contamos sus victorias, y un Aníbal a la hora de ejercer la venganza" ${ }^{35}$, para concluir con uno de los más crueles retratos que hayan podido hacerse en el ámbito de la historiografía.

Especialmente controvertido puede resultar el juicio que le merecieron los protagonistas de la segunda guerra civil, César y Pompeyo. A ambos les asistían razones: «Un hombre severo - dice Veleyo Patérculo - alabaría más el partido de Pompeyo; un hombre prudente seguiría el de César» ${ }^{36}$.

Valerio Máximo es menos ambiguo que Veleyo Patérculo y, si bien reconoce los grandes méritos políticos de ambos contendientes, ya desde el comienzo mismo de la obra ${ }^{37}$ manifiesta que el predestinado de los dioses era César: "Con todos estos prodigios quedaba claro que la voluntad de los dioses quería dar a entender que era favorable a la gloria de César a la vez que quería evitar el error de Pompeyo», así como la ceguera de Pompeyo que «durante la guerra civil, por una resolución tan funesta para sí mismo, como inútil para la república, había roto su alianza con César».

La razón de Estado que roza el nacionalismo patriótico se impone siempre de manera constante a lo largo de los sucesivos ejemplos. Así se observa en las frecuentes antítesis como familia / Estado, bienes privados / interés público: padres que matan a sus hijos para hacer respetar las leyes (Bruto, Postumio Tuberto, el padre de Espurio Casio) ${ }^{38}$; legisladores que se suicidan por el mismo motivo (Carondas), o se mutilan (Seleuco); ejecuciones de traidores o de aspirantes a la tiranía (Marco Manilio, Espurio Melio, Espurio Casio, P. Municio).

El amor a la patria como base de la reconciliación iniciada por Augusto era un concepto político ya ampliamente difundido en la cultura griega y

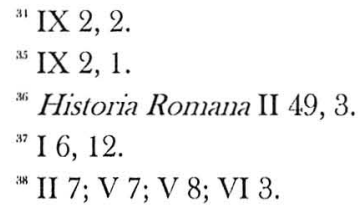


después por Cicerón como «el mayor sentimiento común de voluntades en toda empresa y en el que radica toda la fuerza de la amistad ".9. Pero esta amistad y amor, en el sentido aristocrático de la nueva cultura, sólo podía darse inter bonos, tal como ya había puesto de manifiesto Salustio: «Desear lo mismo, odiar lo mismo, temer lo mismo es la base de la amistad. Pero se llama "amistad" entre los buenos, "facción" entre los malos".

\section{El exemplum en la Edad Media}

La literatura paremiológica con sus sententiae y refranes fue un género privilegiado en la Edad Media. Basaba su éxito en los tradicionales Disticha Catonis (moralia) y en los Proverbios del Pseudo Séneca con que se iniciaban en los estudios de la lengua latina (Sandys); pero más que nada en la concomitancia con otros factores, ahora nuevos, en los que el exemplum se revelaba como el mejor medio de cumplir varias funciones a la vez:

1. Servía a los clérigos para las predicaciones; por eso, en detrimento de Valerio Máximo, los ejemplos que ahora se emplean en los sermones son tomados de las vidas de santos, de Padres de la Iglesia o incluso de la Biblia, y cuando lo hacen de los autores paganos, sólo como contrate, porque el objetivo principal no es tanto difundir un código de virtudes cuanto invitar a la penitencia:

Valent eciam exempla ad futurorum malorum evitacionem, ad viciorum detestacionem, ad desesperatorum revocacionem ad spem et ad presumptuosorum humiliacionem, ad perversorum conversionem et provocacionem ad penitenciam, ad penitencium erudicionem, ad conversorum et mestorum consolacionem, ad tentatorum communicionem, ad tribulatorum et mestorum consolacionem, ad debilium corroboracionem, ad bonorum temporalium debitam dispensacionem, ad bonorum spiritualium adquisicionem, augmentacionem, conservacionem et debitam dispensacionem, et ad amoris Dei et proximi inflammacionem, ad bonorum eternorum pregustacionem, impetracionem et adepcionem; quod per totum opus poterit apparere"t.

"2icerón, Sobre la amistad 4, 15.

"Salustio, Guerta de Yugurta 31, 14-15.

" ALBERT LECOY DE LA MARCHE, Anecdotes historiques, légendes et apologues, tirés du recueil inédit d' Étienne de Bourbon, dominicain du XIII siècle, Paris, XLVIII-4.66 pp. 12-13. 
"Sirven también los ejemplos para evitar los males futuros, detestar los vicios, llevar de nuevo esperanza a los desesperados y humildad a los presuntuosos, para la conversión de los perversos y la invitación a la penitencia; para adoctrinar a los penitentes, llevar consuelo a los conversos y afligidos, fortaleza a los que se sienten tentados y consuelo a los que están atribulados y tristes, fuerza a los débiles, la debida displicencia de los bienes terrenales, la adquisición, aumento, conservación de bienes espirituales y su debida administración, y también el entusiasmo por el amor a Dios y al prójimo, así como el paladear por anticipado, obtener y adquirir los bienes eternos. Todo ello podrá aparecer a lo largo de la obra”.

Item, audivi a quodam fratre quod quidam rex curiam convocavit et promisit quod illi daret filiam suam qui manus haberet pulcriores. Audiens hoc, quidam faber, niger factus iuxtafabricam, totam curam suam posuit ad hoc ut manus suas sollicite lavaret et mundaret, et, venditis omnibus suis, emit anulos et cyrothecas ut eas ornaret. Cum autem venisset ad curiam et omnes propter exteriorem nigredinem expellerent et irriderent, denudatis ejus manibus et anulis, invente sunt pulcriores. Et sic regis filiam et regnum optinuit.

Hic faber est penitens per penitentiam hic denigratus. Rex iste Deus est. Curia ejus judicium ejus est. Filia est ejus gloria quam in Judicio alli non habe-bunt nisi per penitentiam emundaverunt et bonis operibus eas orneverunt ${ }^{12}$.

"También oí a cierto predicador que un Rey convocó al Consejo Real y le prometió que entregaría la mano de su hija a aquel que tuviese las manos más limpias. Oyendo esto, cierto artesano, completamente tiznado por estar al lado del fogón, puso todo su empeño en este objetivo: lavar y dejar bien limpias sus manos: así que, vendidos todos sus bienes, compró unos anillos y sortijas señoriales para adornar las manos. Cuando llegó ante el Consejo Real, todos intentaron expulsarle de allí em medio de risas por su negritud; pero, dejando al aire sus manos y anillos, resultaron ser las más hermosas. Y de este modo obtuvo la mano de la hija dal Rey y su reino.

"ÉTIENNE DE BOURBON, Tractatus de diversis materüs predicabilibus, ms. París, Bibl. nat., lat. 15970, fol. 245 b-c. 
Este artesano es el penitente completamente tiznado por la penitencia. El Rey ese es Dias. Su Consejo Real es el Juicio de Dios. Su hija es la Gloria que en el Juicio tendrán solo los que han purificado su alma por la penitencia y la han adornado con las buenas obras".

2. Formaba a las élites, no sólo a las masas, dando a conocer el complejo mundo, al que se accede básicamente por el desarrollo de los florilegios, ya que en palabras de V. de Beauvais había: "poco tiempo, memoria escasa y multitud de libros».

3. Es un género hermano de los apotegmas que se vieron favorecidos en su desarrollo por la difusión de cuentos orientales vertidos al castellano en el siglo XIII, el siglo de oro del exemplum, entre otras razones, porque se traducen el Calila e Dimna y el Sendebar; dos paradigmas de la literatura sapiencial hispano-oriental destinados a la educación de príncipes y gobernantes y considerados en la Corte de Alfonso X el Sabio como verdaderos compendios de sabiduría. El siglo XIII es por ello también el siglo por antonomasia de las Artes praedicandi:

- De modo praedicandi (Alejandro de Ashby)

- Summa de arte praedicandi (Tomás de Salisbury)

- Ars conficiendi sermones (Jean de la Rochelle)

- De arte praedicandi (Guillaume d' Auvergne)

- Disciplina clericalis (Pedro Alfonso de Huesca). Un verdadero bestseller de la época, que clasifica por temas, como Valerio Máximo, tales como ejemplos para la confesión, contrición, conversión, tentación, etc ${ }^{19}$.

Para facilitar la consulta y ayudar al orador que carece de ideas o de inspiración se buscan métodos clasificadores, de ahí que los haya por orden alfabético, como el del anónimo franciscano inglés, Liber exemplorum ad usum praedicantium de 1275. Otros siguen un método tan curioso como el de añadir al final de cada ejemplo una frase: hoc etiam valet ad... "este vale también para...", como procede el dominico Amoldo de Lieja en su Alphabetum narrationum. Y hay por fin una tercera forma de catalogar: introducir un índice temático con reenvíos ordenados alfabéticamente, como hizo el franciscano anónimo autor del Speculum exemplorum de 1480.

"Para más información al respecto, cf. A. GÓMEZ MORENO, Espaia y la Italia de los humanistas. Primeros ecos. Gredos, Madrid 1994, p.216 y ss. 
En castellano tenemos estos procedimientos en tres libros: El libro de los gatos (1350-1400), el Libro de los exemplos por ABC de Clemente Sánchez de Vercial (1400-1421) y el Espéculo de los legos (1447-1455).

Y entramos así en el último apartado.

\section{Los exempla en los Studia humanitatis}

Los Studia humanitatis comprendían 5 disciplinas: literatura, gramática,

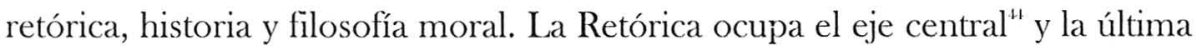
en incorporarse es la filosofía moral para justificar las funciones del buen gobernante, si bien es verdad, que no suponía ninguna novedad respecto del mundo clásico, una vez que son bien conocidos Séneca y Tácito en cuantas reflexiones aportan sobre la forma de gobierno ideal.

$\mathrm{Al}$ respecto fue decisiva la llegada de Manuel Crisolaras a Florencia en 1397, invitado por Coluccio Salutati, para enseñar griego a un selecto grupo de alumnos: Leonardo Bruni, Niccolo Niccoli, Umberto Decembrio, Guarino Guarini, etc. Mediante traducciones al latín se dieron a conocer autores como Plutarco.

La filosofía moral se convirtió en campo de batalla entre humanistas filólogos y juristas, entre rétores y juristas, porque así reivindicaban su presencia en las cortes europeas y estados italianos con su capacidad de influir en los gobernantes. En este contexto la historia gozó de especial consideración porque estaba fuertemente imbuida de doctrina moral desde Salustio y a la vez propiciaba exempla de conducta y modelos de príncipes.

Todo esto plantea un problema crucial: si el mundo clásico debe imponerse como paradigma absoluto o ha de ser un instrumento para construir una nueva civilización. Para conocer mejor este mundo se traduce al vulgar de toda la literatura clásica; por eso, con razón, Gilbert Highet dice que «el Renacimiento es la gran época de la traducción»".

Valerio Máximo encuentra en este contexto terreno abonado para ser uno de los clásicos más leídos e influyentes en autores como el Marqués de Santillana, concretamente en sus Proverbios o Centiloquio, escrito en 1437

\footnotetext{
" P. O. KRISTELLER, El pensamiento renacentista y sus fuentes, México, 1982.

"s G. HIGHET, La traducción clásica. Influencias griegas y romanas en la Literatura occidental, I, México, 1978.
} 
para el príncipe heredero Don Enrique: «La sciencia non enbota el fierro de la lança, ni faze floxa la espada en la mano del cavallero»"

También en el discípulo de Alfonso de Cartagena, Diego Rodríguez de Almela, autor de un Valerio de las Estorias Escolásticas e de España ${ }^{17}$.

A finales del siglo XV Valerio Máximo es el autor de moda como se ve por las numerosas glosas y comentarios de la mano de Lucca Manelli o la versión de fray Antonio Canals, sin duda, gracias a la influencia de traducciones francesas, como la iniciada por Simon Hesdin y concluida en 1401 por Nicolás de Gonesse, que terminó siendo traducida al español por Hugo de Hurries en 1467.

La literatura de apotegmas, de relatos jocosos, que había iniciado sus pasos en los carmina convivalia y las escuelas de retórica, discurrió con soltura en Valerio Máximo y Plutarco, aunque se desvió en cierta medida por la senda de ejemplos de tema jocoso para captar mejor al auditorio. Conscientes del poder de seducción, los predicadores terminaron abusando de esta vía, lo que en gran medida contribuyó a su extinción, como observamos en el proemio al lector de la traducción de los Apotegmas de Erasmo, escrito por Thámara: «Llámase este libro de los Apotegmas, que es de los dichos donosos y graciosos, que cerca de algún propósito fueron hablados y apropiados por los antepassados, no menos sabia y prudentemente que graciosamente, assí para motejar o burlar o escarnecer como para consolar, exortar o amonestar alguna cosa que veían o querían persuadir, y finalmente para demonstrar y dar a entender cualesquiera affectiones y movimientos del coraçón» (Thámara, Apothegmas y dichos graciosos y notables).

A este proceso no fueron ajenos incluso los jesuitas. El P. Juan Bonifacio en carta dirigida a sus superiores relata el esquema pedagógico y didáctico que se practicaba en los Colegios de los Jesuitas, distinguiendo entre autores "ejemplares" en la temática y amenos en el relato, por el número de anécdotas y exempla que introducen, aptos para los alumnos menos dotados, y otros escritores "serios"” para los que poseen conocimientos más profundos de la lengua latina: «La misma caridad que nos mueve a enseñarlos sin esperanza alguna de recompensa terrena, nos obliga, una vez que han aprendido bien la

"A. GÓMEZ MORENO - M.P.A.M. KERKHOF (eds.), Íñigo López de Mendoza, Marqués de Santillana. Obras completas. Barcelona, 1998, p.218-219.

"J. TORRES FONTES (ed.), Diego Rodríguez de Almela, Valerio de las Estorias Escolásticas e de España, Real Academia Alfonso X el Sabio, Murcia, 1994. 
Gramática, a enviarlos a otras facultades. Bien sabes tú la cautela con que procede en todo la Compañía y cuan enemiga es de hablar. Por eso explicamos todavía (yo mismo se lo aconsejé a nuestros superiores) los preceptos de la antigua gramática, por condescender con algunos que nos lo pidieron, que parecen del número de aquellos, que, después de inventados los cereales, siguen manteniéndose de bellotas. Por eso todavía, Vives entre nosotros; por eso tengo yo que explicar, a veces diariamente, los cinco escritores difíciles, por dar gusto a los que buscan el saber hablar bien. Por lo mismo me presto sin dificultad a leer a Valerio Máximo, a Suetonio, a Alciato; declaro algunos pasajes de Amiano Marcelino, de Plinio, de Pomponio Mela; traduzco algunos trozos difíciles del Breviario y algunos himnos eclesiásticos, el catecismo, las cartas de San Jerónimo y el Concilio tridentino. A mis discípulos ordinarios les leo Cicerón, Virgilio y alguna vez las tragedias de Séneca; Horacio y Marcial expurgados, César, Salustio, Livio y Curcio para que tengan ejemplos y modelos de todo ...».

La utilidad moral se adueñó también de las otras artes, especialmente de la escultura, y así, Pedro de Valencia, en una iconografía que remite a Valerio Máximo, relata las cuatro virtudes fundamentales: Prudencia, Justicia, Fortaleza y Templanza. Y Domingo Andrés a la pregunta de si deben escribirse los hechos vergonzosos de los príncipes, responde: «Si no está permitido decir nada ignominioso de los príncipes, ¿qué piensas que es el inventar sus hermosas acciones? ¿Qué? El príncipe se creerá, gracias a mi ingenio, que él hace las mejores acciones, él, el peor por sus hechos: su defecto se engrandecerá hasta hacerse quizá soportable, pues la gloria lograda hace a los ánimos ligeros; si silencio sus maldades, parecerá que calladamente estoy de acuerdo: a donde quiera que me incline, finalmente, grande será mi culpa. Por lo tanto, a lo que yo no puedo poner fin con mi espada, al menos me esforzaré en tacharlo con mi pluma: desprecio las amenazas. Pero si el narrar cosas inenarrables es cosa grave, ¿qué no será el haberlas cometido? Quien no quiere que se escriban sus vergüenzas, que las haga» (Poesías, III 47).

\section{La crisis y el hastío}

El abuso de este procedimiento, que con frecuencia cuidaba más deleitar que enseñar, provocó que muchos humanistas se cuestionaran la utilidad de seguir con ejemplos, especialmente paganos, para propagar la 
doctrina moral y sobre todo de la iglesia. Dante terminó por decir del ejemplo:

«Cada cual por brillar se ingenia y hace

sus inventos, que se andan predicando

mientras callado el Evangelio yace [...]

No dijo Cristo a su primer convento:

"Andad a predicarle al mundo chanzas",

pues les dio la verdad por fundamento [...]

Mas hoy se usa del chiste y la friolera

al predicar: con tal de que se ría,

se hincha el capucho y nada más se espera».

(Paradiso, XXIX, 88-96).

\section{Y Erasmo concluye:}

«El espíritu humano está hecho de tal manera, que le es más accesible la ficción que lá verdad. Si alguien quiere una prueba palpable y evidente de esto, que entre en una iglesia cuando haya sermón, y allí verá que si se habla de algo serio, la gente bosteza, se aburre y acaba de dormirse; pero si el voceador (me he equivocado, quise decir el orador) comienza, como es frecuente, a contar algún cuento de viejas, todos despiertan, atienden y abren un palmo la boca" (Elogio de la locura, IV-3, 130. Ed. Betty Radice, Univ. de Toronto 1986, p.118).

¿Qué ha ocurrido entre estos dos referentes cronológicos?

Los humanistas reaccionan contra estos florilegios porque eran un sucedáneo de los propios autores clásicos, cuyos textos reivindican en su integridad, mientras que los medievales no tenían demasiado interés en deslindar lo auténticamente clásico de las interpolaciones o materiales apócrifos insertos en la tradición. Fernando de Rojas, para ganarse a los lectores, dice en el proemio de la Celestina que añade alguna de aquellas «delectables fontezicas de philosophia" y mientras algunos lectores tan sólo "pican los donayres y refranes comunes", los más formados "coligen la suma para su provecho, ríen lo donoso; las sentencias y dichos de philosophos guardan en su memoria para transponer en lugares convenibles a sus autos y propósitos». 


\section{CONCLUSIÓN}

Los prejuicios sobre la literatura no eran los mismos para un humanista y un medieval que para nosotros. Aunque los hombres cultos considerasen inexcusable leer a los clásicos, por razones docentes y sencillamente por prurito de erudición y cultura, los profesionales de la literatura sacaban provecho de las colecciones de moralistas cuya lectura recomendaban para erradicar de las aulas otras lecturas menos provechosas, como los romans o relatos novelescos que volvían loca a la gente. El Quijote, por ejemplo. En el prólogo de Nebrija a su Gramática, el varapalo a las falsas historias del Valerio apunta ya en esta dirección.

En consecuencia, la impronta moral de los florilegios fue considerada de máxima utilidad en la práctica docente y en el ejercicio de la memoria; por eso, una vez aparecida la imprenta, se editaron el Speculum maius de Vicent de Beauvais y el Florilegio de sentencias de Thomas Ibernicus. Pero la imprenta misma hacía más fácil el control de la totalidad de un autor sin la imperiosa necesidad de contar sólo con el vademécum colectivo de anécdotas y ejemplos.

Por otra parte, la biografía, que había vivido a la par que los otros subgéneros historiográficos, se desarrolló especialmente en el Renacimiento bajo la modalidad de hombres ilustres y el retrato panegírico. No es casual que el retrato sea la principal novedad en la pintura y la escultura. Palabra e imagen recuperaban un género clásico con fines propagandísticos; pero ahora ya los nuevos modelos habían suplantado a los clásicos, como los modelos cristianos suplantaron a los paganos en las artes predicatorias. El viejo modelo ya sólo importaba como mecanismo, no como referente directo: se exalta a la patria mediante el elogio de los grandes hombres del pasado, pero fundamentalmente con los de su propia época, como se aprecia en el breve catálogo que sigue:

- Juan Gil de Zamora, (Liber illustrium personarum);

— Juan Fernández de Heredia (Crónica de los conqueridores, donde Jaime I de Aragón es comparado con Alejandro Magno y el emperador Augusto);

- Giannozo Manetti (Liber de illustribus longevis), que se remonta a personajes bíblicos; 
- Bartolomé Facio (De viris illustribus, que sirvió de modelo en la corte de Alfonso V el Magnánimo);

- Pere Miguel Carbonell (De viris illustribus catalanis suae tempestatis libellus).

Todos tenían in mente a Valerio Máximo, Suetonio y Plutarco; pero, víctima de su propio éxito y de querer ser un fin en sí mismo, en el plano político y nacional el ejemplo profano terminó siendo "actualizado" por los nuevos modelos, y en el plano moral, el canon de virtudes, aunque siguió vigente, miró hacia los textos bíblicos y sagrados: lo ejemplos paganos terminaron siendo prohibidos en sucesivos concilios (Letrán, 1516; Sens, 1529; Milán, 1565; Burdeos, 1624). 
(Página deixada propositadamente em branco) 
GEOANTROPOLOGIA E IMPERIALISMO EM PLÍNiO O ANTIGO*

Francisco de Oliveira

(Universidade de Coimbra)

\section{1 - Preâmbulo}

Nos livros sobre geografia e em numerosos excursos geográficos e etnográficos, Plínio o Naturalista deixa entrever de forma clara uma visão do outro que, por um lado, se reporta a algumas vertentes da teoria política antiga, e, por outro, denota uma percepção do mundo claramente romanocêntrica, que circunscreve um espaço civilizacional itálico, europeu e ocidental.

\section{2 - A superioridade de Roma: laudes Romae 'louvores de Roma'}

Um significativo conjunto de passos da História Natural exalta a superioridade de Roma sobre todos os outros povos, impérios ou regiões. Trata-se de um topos literário que, sob o ponto de vista da retórica discursiva, chamarei laudes Romae'.

*Com a devida autorização do editor, o texto, apresentado em Junho de 2005, em Coimbra, no congresso internacional "Génese da ideia de Europa", é uma versão alterada e acrescentada da que publiquei em Actas del XI Congreso de la Sociedad Española de Estudios Clásicos, I, Madrid, 2005, p.535-546.

Cf. Quint.Inst.4.3.12-13, sobre a egressio: laus hominum locorumque, ut descriptio regionum, expositio quarundam rerum gestarum, vel etiam fabulosarum 'o louvor dos homens e lugares, tal como a descrição de regiões, é a exposição de alguns feitos, inclusive os lendários'; 
Nesses louvores de Roma, especificarei três formas da sua concretização:

- a primeira, de origem médica e geográfica, divide o globo em cinco zonas e privilegia a zona temperada norte, numa visão geopolítica;

- a segunda, evocadora das coevas e omnipresentes colectâneas de feitos dignos de memória (collectanea rerum memorabilium), regista-se através dos lexemas primus, primum, principatus, claritas, comparare, gloria, gloriari, honos, nobilitas, palma, vincere, vários deles concretizados no caso em apreço, e por meio das diversas formas de superlativação;

- a terceira exprime-se mediante a ideologia da victoria e da missão imperial e providencial.

O denegrimento de outros povos e impérios, que se socorre de figuras e lemas de retórica, de tiradas moralistas e até, é minha intuição, da fisiognomonia (cf. $6.88 ; 7.16-18$ ), será tratado no item vituperatio e em seus desdobramentos:

- a percepção do desconhecido, do bárbaro e do inculto;

— a aparência física e hábitos de vida;

- a reformulação e crítica de conceitos.

\section{1 - Geoantropologia e destino imperial}

Na novidade e imprecisão da delimitação dos circuli 'círculos', paralleli 'paralelos', segmenta 'segmentos' ou comprehensiones 'zonas' terrestres referidos em 6.211-220, e tendo em conta a teoria das zonas celestes mencionada em 2.171-172, facilmente se deduz a colocação da Itália na zona tempe-

para a expressão laudes Romae, ver W. Gernentz, Laudes Romae, Rostock, 1918; para o tema em geral, remeto para a seguinte bibliografia: R. Dion, Aspects politiques de la géographie antique, Paris, 1977; R. Girot, "Vision et représentation géographiques chez les anciens", in: Mélanges R. Dion, Paris, 1974, p.481-498; F. Klingner, "Rom als Idee", in: Römische Geiteswelt, München, 1979, p.645-666; B. Kytzler, Ronı aeterna, Zürich, 1972; R. Moynihan, "Geographical mythology and Roman imperial ideology", in: The age of Augustus, ed. R. Winkles, Louvain, 1985, p.149-162; C. Nicolet, L’inventaire du monde. Gćographie et politique aux origines de l'empire Ronıain, Paris, 1988; L. Pernot, Éloges grecs de Rome, Paris, 1997; D. Thompson, The Idea of Rome from the Antiquity to the Renaissance, Albuquerque, 1971. 
rada norte ${ }^{2}$. As vantagens políticas de tal localização são bem expressas em 2.190:

medio vero terrae salubri utrimque mixtura fertiles ad omnia tractus, modicos corporum habitus magna et in colore temperie, ritus molles, sensus liquidos, ingenia fecunda totiusque naturae capacia, isdem imperia, quae numquam extimis gentibus fuerint, sicut ne illae quidem his paruerint, avolsae ac pro numine naturae urguentis illas solitariae.

Mas na zona intermédia, graças a uma salubre mistura de ambos os elementos (sc. fogo e humidade), as terras são férteis para todas as culturas, moderadas as proporções dos corpos, é também grande o equilíbrio da cor, os costumes civilizados, os sentidos apurados, o engenho fecundo e capaz de abarcar toda a natureza; são delas os impérios, os quais nunca pertenceram a terras dos confins, pois estas nem sequer àquelas estiveram submetidas, repelidas e solitárias como que por vontade de uma natureza hostil.

Além disso, a própria geografia da Itália, bem colocada no centro dessa zona central (cf. 7.9), favorece claramente o destino imperial romano.

Pelo contrário, como respondendo a um desígnio superior, algumas regiões parecem condenadas pela natureza (Pteróforo, segundo 4.88); outras, apesar da excelência da localização, como Palmira, são prejudicadas pela fortuna (5.88); o Ponto Euxino está sujeito à erosão marinha permanente, peculiari invidia naturae (6.1); a região dos Caucos é palco da luta entre terra e água (16.2).

Especial é o caso dos Citas (6.51-53), os quais, além de nómadas, habitando uma região inóspita por causa das neves, se caracterizam por uma saevitia 'ferocidade' que se traduz em antropofagia e por uma inmanitas 'desumanidade' não dissemelhante da das feras que os rodeiam.

Desta forma, somente a Europa e a Itália estavam destinadas a gerar uma imperiosa civitas 'cidade poderosa', para usar uma sugestiva expressão de Cícero (Rep.3.36). E, como diz o mesmo Cícero sobre a excelência da localização de Roma, no acto da fundação, o próprio Rómulo “já então adivinhava

\footnotetext{
" A teoria das zonas climáticas relaciona-se com a medicina hipocrática, foi elaborada por Posidónio, aparece em Políbio e Estrabão, transparece em Cícero, Vitrúvio, Virgílio e Séneca. Cf. C. Nicolet, L'inventaire du monde. Géographie et politique aux origines de l'Empire romain, Paris, 1988, cap.III.
} 
que esta cidade forneceria um dia a sede e a morada ao maior dos impérios; de facto, não poderia a urbe deter com mais facilidade tal poderio sobre as coisas se situada nalguma outra parte da Itália”.

\section{2 - Grandeza e excelência da terra e das suas produções}

Logo em 2.18 a Europa é apresentada como

.... terrarum pulcherrima, quam plerique merito non tertiam portionem fecere, vero aequam, in duas partes ab amne Tanai ad Gaditanum fretum universo orbe diviso.

... a mais bela das terras, que a maioria com justeza considerou não a terça parte, mas metade, dividindo o orbe em duas partes, do rio Tânais até ao estreito de Gades.

Em 6.210, especifica-se que ocupa um terço e pouco mais de oito avos, sendo por isso maior que a Ásia e que a África (segundo 6.59 a Índia ocupa um terço do orbe).

A Itália, dïs sacra 'consagrada aos deuses' (3.138), é caracterizada por uma enorme nobreza dos lugares e pelo brilho dos habitantes (3.40): tanta nobilitas omnium locorum ... tanta rerum singularum populorumque claritas tenet). Na abundância de metais, a nenhuma terra é inferior (nullis cedit terris); produziu mais génios que todas as outras terras juntas (7.112), incluindo, especificamente, um exemplo de pietas 'afeição familiar', ao qual nenhum outro se pode comparar (7.121: comparari cuncta non possint); em suma, Roma sobressaiu como a mais notável das nações (7.130):

Gentium in toto orbe praestantissima una omnium virtute haud dubie Romana extitit.

68

Em todo o orbe, de todas as nações, a mais cheia de virtude, no seu conjunto, é indubitavelmente a romana.

\footnotetext{
"Cic. Rep.2.10, onde o elogio de Roma se relaciona com o tema das urbes maritimae 'cidades marítimas': Vt mihi iam tum divinasse ille videatur hanc urbem sedem aliquando et domum summo esse imperio praebituram; nam hanc rerum tantam potentiam non ferme facilius alia ulla in parte Italiae posita urbs tenere potuisset.
} 
O elenco das produções também dá a superioridade à Itália, de tudo vencedora (cf. 13.18: in Italia victrix omnium; e 37.201-202).

Por sua vez, a cidade de Roma aparece como um sítio privilegiado na Itália, digna iam tam festa cervice facies 'rosto já digno de tão encantadora cabeça' (3.40); quanto à sua grandeza territorial, deve confessar-se que em todo o orbe não há igual (3.67: nullius urbis magnitudinem in toto orbe potuisse ei compararı).

Ao próprio Tibre, placidissimus 'extremamente sereno', para além do carácter sagrado, é atribuída a superioridade sobre todos os outros rios (3.54-55).

Assim, mais uma vez se circunscreve a excelência geográfica e etnográfica à Itália e a Roma; e, como diria Políbio, excelência quer dizer aptidão para dominar.

2.3 - Roma victrix parensque mundi altera 'Roma vencedora e segunda mãe do mundo'

A ideologia da vitória aparece de forma recorrente nas referências a Roma e aos Romanos. Assim, ouvimos falar de populi gentium victoris 'povo vencedor das nações' e de Romani nominis gloriae 'glória do nome de Roma' (praef.16), da Europa como altrice victoris omnium gentium populi longeque terrarum pulcherrima 'ama do povo vencedor de todas as nações e de longe a mais bela das terras' (3.5; cf. 13.18: in Italia victrice omnium 'na Itália, de todos vencedora'); o povo romano é qualificado como terrarum victor et totius domitor orbis 'vencedor de todas as terras e domador de todo o orbe' (36.118).

A missão imperial e providencial é exposta muito claramente com os marcadores da superioridade civilizacional e linguística da Itália (3.39):

... terra omnium terrarum alumna eadem et parens, numine deum electa quae caelum ipsum clarius faceret, sparsa congregaret imperia ritusque molliret et tot populorum discordes ferasque linguas sermonis commercio contraheret ad conloquia et humanitatem homini daret breviterque una cunctarum gentium in toto orbe patria fieret.

... uma terra que é ama e progenitora de todas as terras, por vontade dos deuses eleita para tornar o próprio céu mais luminoso, congregar 
impérios esparsos e civilizar costumes, arrastar ao entendimento tantos povos desavindos e línguas selvagens avessas ao comércio da fala, e dar humanidade ao homem, em suma, fazer de todo o orbe uma só pátria para todas as nações.

Essa superioridade civilizacional e esse destino imperial romano assumem claramente um carácter numinoso (3.41-42):

... tot maria, portus, gremiumque terrarum commercio patens undique et tanquam iuvandos ad mortales ipsa in maria procurrens. Neque ingenia ritusque ac viros et lingua manuque superatas commemoro gentes.

... tantos mares, portos e o seu regaço aberto por todos os lados ao comércio entre as terras, ela própria avidamente avançando para o mar como para ajudar os mortais! Sem mencionar os engenhos, os costumes e varões, e as nações vencidas pela sua língua e pela sua mão!

Aqui, por contraste, a ocorrência de mortales coloca a Itália na posição de imortal, e o lexema ad iuvandos evoca enunciado similar, em 2.18, onde esse traço é consagrado como originário, histórico e específico dos Romanos:

deus est mortali iuvare mortalem, et haec ad aeternam gloriam via. Hac proceres iere Romani ...

Divino é, para um mortal, ajudar outro mortal, e é esta a via para a glória eterna. Por ela avançaram os próceres romanos ...

Da mesma forma, tal como em 36.118 o povo romano é descrito como deorum quaedam immortalium generi humano portio 'uma como que parcela dos deuses imortais junto do género humano', assim também em 27.3 essa posição providencial é colocada como um vicariato divino (Adeo Romanos velut alteram lucem dedisse rebus humanis videntur 'Assim os deuses parecem ter criado os Romanos como uma segunda luz para os seres humanos), com a imensa maiestas 'majestade' da paz romana a permitir que todos os produtos do orbe estejam em todo o lado à disposição de todos, para bemestar da humanidade (humanae saluti). 
O registo numinoso inerente ao emprego de maiestas reaparece em 14.2, onde está novamente ligado ao conceito de paz e de império universal:

quis enim non communicato orbe terrarum maiestate Romani imperï profecisse vitam putet commercio rerum ac societate festae pacis, omniaque, etiam quae antea occulta fuerant, in promiscuo usu facta?

Quem é que, atendendo às comunicações entre todo o orbe da terra estabelecidas pela majestade do império romano, não há-de considerar que a civilização progrediu com o comércio dos bens e a partilha de uma paz festiva, e que tudo, inclusive o que antes estava oculto, se tornou de uso comum?

Como se pode constatar, à excelência da situação corresponde um destino imperial providencial, numinoso e tendencialmente eterno, que se concretiza tanto em dominação directa como na garantia de contactos comerciais, diplomáticos, civilizacionais.

\section{3 - Vituperatio do desconhecido, do bárbaro e do inculto}

Vejamos agora como, por contraste, nenhum outro povo recebe os elogios de Roma. Pelo contrário, mesmo quando a excelência da localização, da organização ou das produções é conhecida, Plínio encontra forma de a inferiorizar por razões morais ou de a desqualificar por incerta ou lendária.

O denegrimento de outros povos é rastreado através de um conjunto de lemas que tradicionalmente marcam a ausência de civilização e é metodologicamente clivado por um conceito de enciclopedismo selectivo.

\section{1 - Nomes indignos de pronúncia e de memória}

Na descrição da Índia, Plínio observa que os seus povos são inúmeros. Elencá-los a todos seria cair no conceito de diligentia (6.58-59): non tamen est diligentiae locus: adeo diversa et incredibilia traduntur 'Não há espaço para exactidão, tão diverso e incrível é o que se conta'. Recordará somente as nações ... quas memorare non pigeat 'que se podem recordar sem sentir vergonha' (6.64). 
De facto, com frequência Plínio omite mencionar povos pelo facto de terem nome ignóbil e bárbaro, como no caso do conventus Lucense, ou para não causar fastio, como a propósito dos Brácaros (3.28).

O critério linguístico de selecção é explanado a propósito do Ilírico (3.139): omissão de nomes pouco dignos de serem pronunciados, difíceis de pronunciar ou que se não podem pronunciar sem vergonha (ver também 4.40, para a Trácia; 4.117-118, para a Lusitânia; 5.105-106 para a Cária).

Na sua vertente linguística, tal selecção remete os povos não mencionados para a categoria etimológica da barbárie, que explicitamente se estende à Escandinávia (4.96-97), à África, na região da Líbia e do Egipto, em que os nomes das povoações são extremamente difíceis de pronunciar e na bárbara língua local (5.1), a certas regiões mesopotâmicas da Síria (5.82) e à Arménia (6.27). Todavia, isso não impede a reprodução de alguns nomes bárbaros (cf. 5.151, para a Bitínia).

Este critério é também válido para regiões não romanizadas do império, como no caso da Hispânia, particularmente as zonas com vestígios de ocupação e toponímia celtas (3.13, sobre a Bética, e 4.118, sobre a Lusitânia)".

Por sua vez, tendo em conta as acepções registadas pelo dicionário etimológico de Ernout-Meillet, o conceito distintivo de ignobilis 'que não merece ser conhecido, desconhecido, obscuro', oposto a memorandus 'digno de memória' (cf. 3.147-148), a nominandus 'digno de ser nomeado' (e.g. 4.111) e até a gloria 'glória' (cf. 5.60), nobilitas 'nobreza, celebridade', nobilis 'nobre, célebre' e noções similares (cf. 5.126: inhonorae civitates 'cidades desprezíveis' da jurisdição de Pérgamo), é bastante frequente. Para além de alguns passos anteriores, ver também 4.74 para algumas ilhas das Espórades, 5.106 para a região da Cária; 111, para a Lídia; 123, para a Mísia; 129, ilhas da Panfília; 135 e 137, para ilhas da Jónia; 6.80 para a Taprobana. O conceito de ignobilis define-se, segundo 4.62, sobre Creta, pela ausência de uma civilização urbana (sine oppidis et ideo ignobiles).

\section{2 - Aparência física e hábitos de vida inumanos}

Um vasto conjunto de povos exteriores ao mundo romano, ou, para usar a expressão de 5.29, de nações que não se incluem entre as que obedecem ao

\footnotetext{
' Ver os meus artigos "Lusitânia rural em Plínio o Antigo" in: Les campagnes de Lusitanie romaine, Madrid, 1994, p. 31-44; e "A Lusitânia Pliniana", Classica. Boletim de Pedagogia c Cultura 221997 207-222.
} 
império romano (Romano pareant imperio), vê-se caracterizado por lemas tradicionalmente indicadores de animalidade, barbárie e ausência de civilização.

Assim, em longínquas regiões das extremidades da Europa vivem povos com pé de cavalo e orelhas a cobrir todo o corpo nu $(4.95)^{5}$.

Os habitantes da África, na região dos Atlantes, têm todas as características de um quadro de inumanidade, como se verá em 5.44-46, onde se misturam povoadores semiferi 'meio selvagens' ou cujos costumes humanos degeneraram (degeneres humani ritus), e desconhecedores da fala, como os Etíopes mencionados em 6.188, temerosos perante o nascer e o pôr do sol. Outros estão privados da capacidade de sonhar os mesmos sonhos que os outros homens, habitam em grutas, comem carne de serpente, desconhecem o matrimónio, não usam vestuário, não têm cabeça, a boca e os olhos estão cravados no peito, rastejam à maneira de serpentes (5.44-46).

Especialmente negativa é a imagem dos Citas, em 6.51-53, onde se acumulam alguns dos itens já conhecidos: ausência de sede fixa ou nomadismo, saevitia 'ferocidade', incluindo antropofagia, e inmanitas 'desumanidade ${ }^{96}$.

- Os Seres Hémodos do nordeste da Índia lançam os estrangeiros às feras, têm estatura enorme, cabelo rútilo, olhos azuis, produzem sons estranhos, desconhecem a fala (6.88).

De resto, o desconhecimento da fala é um registo de extrema importância e tem a ver com ausência de órgãos fonadores: os já referidos Seres Hémodos caracterizam-se por um ameaçador tom da fala, sem qualquer comunicação com outra língua (6.88: oris sono trucis, nullo commercio linguae); os habitantes de algumas regiões da Etiópia, pela ausência de línguạ (6.187); os habitantes de certos montes da Índia têm um latido em lugar de voz (7.23: pro voce latratum); os Coromandas vivem sem voz, com um estridor horrendo (7.24: sine voce, stridoris horrendr); como o nome indica, os Ástomos não têm boca (7.25: sine ore).

Outras marcas frequentes de derrogação são os qualificativos semiferus 'meio selvagem' e ferus 'selvagem' (cf. 4.3, para os Dârdanos; 5.44 para o interior da África; 6.15-16, no Ponto; 29, nos confins da Arménia; 35, na vizinhança dos Arinfeus; 47, para além do Cáucaso; 54, para Seres semelhantes a

"Cf. D. B. Saddington, "Roman Attitudes to the Externae gentes of the North", $A C 4$ 1961 90-102; sobre a descrição de povos e seus pressupostos epistemológicos, ver R. Lenoble, Esquisse d'une histoire de l'idée de nature, Paris, 1969.

${ }^{6}$ Cf. 6.55 e 7.9-10, onde inclui sacrifícios rituais como os dos druídas, 12 e 18. 
feras; 168, para Árabes da região dos Trogloditas); liber (4.3, para os Dassarenses, vizinhos do Epiro; 6.74: na Índia; 134, para a libera feritas 'selvajaria sem rédea' dos Mizeus (cf. 6.47: gens Mardorum fera, sui iuris); e ainda indomitus 'indómito' (6.30, perto das Portas do Cáucaso); e silvestris (7.11: silvestres ... homines ... passim cum feris vagantes 'homens que vivem nos bosques, vagueando desordenadamente com as feras'; 7.24: Coromandas).

Estes marcadores registam a ideia de ausência de sociabilidade, como se explicita em 6.54, sobre os Seres: et ipsi feris similes coetum reliquorum mortalium fugiunt 'e eles mesmos, semelhantes a feras, fogem do contacto com os restantes mortais'. O traço associal é comum a vários outros povos (cf. 4.81, para os Citas; em regiões interiores de África, ver 5.44 para os Egipãs; 5.55 para os Ganfasantes, que nulli externo congregantur com nenhum estrangeiro se congregam; 5.73 para os Essénios) ${ }^{7}$.

Da mesma maneira, há um desdobrar de lemas indiciadores de negação ou destruição da boa ordem social: a pirataria (6.176: Árabes Ascitas) e o banditismo (ver ocorrência de latrones para os Átalos em 6.125 e para os Óxios da região do Tigre em 6.133; de latrocinium para os Árabes mitrati em 6.162; de infestatores para os Nómadas referidos em 6.14.3); os costumes e práticas aberrantes (cf. 7.13-14: dos Psilos da região das Sirtes; 7.15: andróginos da mesma região; 7.16-18: poderes maléficos do olhar e dupla pupila; 7.30: híbridos resultantes de comércio carnal com animais, na Índia); os cultos infernais (5.45: Augilas) ou teriomórficos (6.178: na região oriental da África; 192: Ptomênfanos da Etiópia); e, finalmente, a famosa intolerância religiosa dos Judeus (13.46: Iudaea gens contumelia numinum insignis).

Por brevidade, declino indicar a numerosa bibliografia específica sobre os Essénios e outros povos em Plínio; o leitor interessado poderá facilmente encontrá-la nas bibliografias existentes; destaco somente dois títulos genéricos sobre as concepções geográficas de Plínio: K. Sallmann, Die Geographie des Älteren Plinius in ihrem Verältnis zu Varro, Berlin, 1971; A. Dihle, "Plinius und die geographische Wissenschaft in der römischen Kaiserzeit", in: Tecnologia, economia e società nel mondo romano, Como, p.121-137. Para a localização das referências, os índices de Ian-Mayhoff são substituídos com grande vantagem por Concordantia in C. Plinï Secundi Naturalen Historiam, curantibus P. Rosumek, D. Najock, Hisdesheim, Olms, 1996, 7 vols; o elenco bibliográfico mais recente é o de G. Serbat, "Pline l’Ancien. Etat présent des études sur sa vie, son oeuvre et son influence" in: ANRW2.32.4 1985 2069-2200.

"Em 2.117 os piratas são considerados inimigos de todos os homens, consequentemente destruidores da civilização; sobre pirataria e banditismo, ver B. D. Shaw, "Der Bandit", in: Der Mensch der römischen Antike, hrsg. A. Giardina, Frankfurt, 1991, p.337-381; Philip de Souza, Piracy in the Graeco-Roman World, Cambridge, 2002 (ed. paperback). 
A ausência de habitação (cf. 6.51: Citas; 6.143: povos vagi 'nómadas' nas proximidades dos Caldeus; 195: Artabatitas da Etiópia, quadrupedes, ferarum modo vagi 'vagueando à maneira dos animais quadrúpedes'; 7.11: habitantes do Abarímon, passim cum feris vagantes 'vagueando desordenadamente com as feras'), ou a habitação em cavernas, bosques, tugúrios e tendas (4.89: Hiperbóreos; 5.45: Trogloditas; 6.109: na Carmânia; 179: Nómadas africanos, in tabernaculis viventes, 7.26-27: Pigmeus de África; 16.3: Caucos); o vestuário inexistente (4.95; 6.190: Gymnetes, semper nudi) ou impróprio (6.110); os adereços macabros (7.12: escalpelos a servir de colares); as características físicas invulgares ou até animalescas (caso extremo dos Etíopes, segundo 6.187-188 e 195-196; cf. 7.10: Arimaspos; 11: habitantes do Abarímon; 7.16-17; 7.22: certos habitantes da Índia, incluindo os gimnosofistas; 7.23-31: catálogo de aberrações, desde homens com cabeça de cão, com uma só perna, um só olho, sem cabeça, sem sombra, até aos que têm orelhas que os cobrem totalmente, em regiões como Etiópia, Índia, Taprobana, Tauro); o desalinho ou exotismo da barba e do cabelo (6.162, para os Árabes); a comida estranha, incluindo canibalismo (caso dos Eonas em 4.95; dos Ofiófagos em 6.169; dos Gimnetes em 6.190; de certos Etíopes em 6.195-196; dos Ástomos em 7.25; dos habitantes do Áton em 7.27); a utilização de glandíferas, nutrices inopis ac ferae sortis 'amas de uma mísera e fera condição', segundo 16.1; a bebida (7.12: beber por caveiras; 16.4: os Caucos só bebem água da chuva) - todos estes lemas são marcas frequentes de incivilidade, em povos da Ásia, da África, do mar Eritreu, de regiões não integradas no império romano.

Por contraste, os Romanos são louvados por imporem hábitos humanos e civilizados, por combaterem todas as monstruosidades, em especial as práticas mágicas, os sacrifícios humanos e a antropofagia (30.12-13):

nec satis aestimari potest, quantum Romanis debeatur, qui sustulere monstra, in quibus hominem occidere religiosissimum erat, mandi vero etiam saluberrimum.

E nunca é demais valorizar quanto se deve aos Romanos, que puseram termo a essas práticas monstruosas, nas quais matar um homem era um acto de extrema religiosidade, e comê-lo até extremamente saudável. 
Aparece mesmo como castigo o facto de um povo não se incorporar no império romano. É o caso dos Caucos, que vivem de forma verdadeiramente não civilizada mas recusam a integração, o que leva Plínio a exclamar (16.1-4):

et hae gentes, si vincantur hodie a populo Romano, servire se dicunt! ita est profecto: multis fortuna parcit in poenam.

E estas nações, se hoje forem vencidas pelo povo romano, afirmam cair na escravidão. É assim, de facto: a muitos a fortuna poupa para seu castigo!

Posição muito próxima da de Séneca, De ira, 2.15.5, quando, a propósito de Germanos e Citas, para além de relacionar a barbaridade com a localização geográfica (Fere itaque imperia penes eos fuere populos qui mitiore caelo utuntur 'Assim geralmente os impérios pertenceram aos povos que beneficiaram de um clima mais suave'), se pronuncia sobre a incapacidade dos bárbaros (De ira, 2.15.4):

Deinde omnes istae feritate liberae gentes leonum luporumque ritu ut servire non possunt, ita nec imperare; non enim humani vim ingenii, sed feri et intractabilis habent.

Ademais, todas estas nações, que são livres por causa da sua selvajaria, como não são capazes de se sujeitar, à semelhança dos leões e dos lobos, também não conseguem comandar; é que têm uma força que não é de um génio humano, mas selvagem e intratável.

\section{3 - Denegrimento por reformulação e crítica de conceitos}

A tradição etnográfica e retórica fornecia certos quadros de povos mais ou menos mitológicos que, a existirem, competiriam com a excelência de Roma. Rastreei esses povos também através do qualificativo felix 'feliz', aplicado aos Hiperbóreos e à Arábia.

No caso dos Hiperbóreos (4.88-91), os seus traços positivos são remetidos para a penumbra da fábula mediante a recorrência das expressões fabulosis celebrata miraculis 'célebre por lendárias marvailhas' e nec licet dubitare de gente ea 'não é lícito duvidar da existência dessa nação'. 
São-lhes associados os Arinfeus, referidos em 6.34-35, sobre cujos aspectos positivos são lançadas marcas negativas: habitam nos bosques, comem bagas, têm habitantes ferozes por vizinhos, isto é, aproximam-se da insociabilidade.

A mesma estratégia discursiva funciona para os Seres que, apesar de mites 'civilizados', são fonte de luxo, receosos de contactos, semelhantes a feras (6.54-55).

Quanto à Arábia, geograficamente tão bem situada como a Itália (6.142-143), Plínio contesta mesmo como ingrato e falso o cognome felix que tradicionalmente lhe é atribuído: é que os seus produtos de luxo funerário de modo algum são mais agradáveis aos deuses do que as ofertas tradicionais; e só a importação de pérolas para o luxo feminino custa a Roma cem milhões de sestércios anualmente (12.82-84). Tal como os da Índia ou do mar Rubro, os seus produtos medicinais são menosprezados por razões morais, económicas e ideológicas (24.4-5).

Sendo certo que a primazia ou summa auctoritas nos perfumes vai para o unguento real criado pelos reis da Pérsia e que nada de semelhante se produz na Itália, a sua classificação como cumulus deliciarum 'cúmulo das delícias' é claramente derrogativa (13.18); além disso, em 14.8 afirma-se que o odor das vinhas itálicas suplanta o odor de quaisquer outras.

No caso do Egipto, o denegrimento da glória passada faz-se por oposição à actual condição ignóbil (5.60). De certa forma o mesmo esquema está implícito na referência à Fenícia, quondam terrarum maxuma et plurimis distincta nominibus 'outrora a maior das terras, que se desdobrava em inúmeras designações' (5.66).

A oposição passado/presente, utilizada em relação à Macedónia $(4.33$ e 39), ao Egipto (5.60), à Babilónia (6.121-122), também denegrida pela existência das práticas mágicas dos Caldeus, funciona de modo especial na referência a Tiro e a Cartago (5.76):

Tyros ... olim partu clara ... et illa aemula terrarumque orbis avida Cartaghine, etiam Gadibus extra orbem conditis: nunc omnis eius nobilitas conchylio atque purpura constat.

Tiro ... outrora célebre pela sua progénie ... e aquela rival (sc. de Roma) e ávida do orbe terráqueo, Cartago, e até Gades, fundada para além do orbe: agora, toda a sua celebridade se resume a uma concha e à púrpura. 
No caso especial dos Essénios, alguns sinais positivos ou de duplo entendimento estão claramente rodeados de referências negativas (5.73).

Quanto à Índia, apesar de nela existirem povos caracterizados por algum grau de civilização (6.66), as numerosas referências positivas são apoucadas pela incerteza e pelo carácter fabuloso das descrições, logo referidos na abertura, e por pinceladas negativas ao longo da descrição: o hábito semiferus de domar elefantes (6.66), a existência de povos silvestres (6.73), liberi (6.74) e governados por rainhas (6.76).

Caso muito sugestivo é a longa e elaborada digressão sobre a Taprobana (6.81-91), onde, após a descrição geográfica, os numerosos apontamentos utópicos são iniciados por uma sátira contra o luxo (6.89):

sed ne Taprobane quidem, quamvis extra orbem natura relegata, nostris vitiis caret. Aurum argentumque et ibi in pretio; marmor testudini simile, margaritae gemmaeque in honore.

Mas, de verdade, nem a Taprobana, embora relegada pela natureza para fora do nosso orbe, cárece dos nossos vícios. Também aí o ouro e a prata têm alta cotação; o mármore semelhante a uma carapaça de tartaruga, as pérolas e as pedras preciosas são apreciadas.

Em suma, o denegrimento leva a que, consequentemente, os outros povos desmereçam qualquer missão imperial ou civilizadora, servindo, quando muito, por contraste e utopia pontuais, como motivo para sátira social (cf. 24.4-5). Mesmo neste caso, essa função é romanocêntrica.

\section{Conclusão}

Sem prejuízo de o próprio Naturalista repetidamente assinalar o carácter fabuloso dos relatos (cf. 7.6: prodigiosa aliqua et incredibilia 'alguns prodigiosos e não críveis'; 7.32: miracula ingeniosa ... inter prodigia posuisse gentes 'colocar nações entre as maravilhas do génio ... e os prodígios'), não deixa de ser verdade que o exótico e o estranho correspondem a estereótipos da barbárie e da monstruosidade (cf. 7.10), por oposição aos traços civilizados da romanidade: costumes, instituições políticas, língua, modo de vida, urbanismo. Trata-se, afinal, dos mesmos motivos que levam os embaixadores 
dos Partos a justificarem perante Cláudio a entrega dos seus príncipes como reféns: para mais tarde terem reis afeitos aos costumes dos Romanos".

$\mathrm{Na}$ abordagem desse outro, o Naturalista conjugou várias heranças culturais e ideológicas, procurando descrever uma oekoumene 'terra habitada' que, afinal, era reconhecidamente diversa e mais vasta que o império universal romano. Criar uma percepção e fazer uma abordagem dessa realidade era um imperativo científico, político e económico ${ }^{10}$.

A superioridade da Itália, à qual quase são comparadas a Hispânia e a Gália, é ainda realçada através da estrutura da História Natural, tanto nos livros geográficos como no fecho da obra, que compendia toda essa ideologia da excelência geoantropológica romana, numinosa e providencial, e do seu espaço imperial (37.201-202):

Ergo in toto orbe, quacumque caeli convexitas vergit, pulcherrima omnium est iis rebus, quae merito principatum naturae optinent, Italia, rectrix parensque mundi altera, viris feminis, ducibus militibus, servitiis, artium praestantia, ingeniorum claritatibus, iam situ ac salubritate caeli atque temperie, accessu cunctarum gentium facili, portuosis litoribus, benigno ventorum adflatu.

Portanto, em todo o orbe, para onde quer que se estenda a concavidade do céu, pelas coisas que, por seu mérito, obtêm o primado da natureza, a mais bela de todas é a Itália, uma segunda guia e progenitora do mundo - pelos seus homens e mulheres, comandantes e soldados, escravos, superioridade nas artes, excelência dos seus génios, até pela localização, salubridade e equilíbrio de um clima temperado,

"Tácito, Anais, 12.10, reproduz a argumentação dos embaixadores dos Partos perante o senado romano: "Ideo regum obsides liberos dari ut, si donestici imperï taedeat, sit regressus ad principem patresque, quorum moribus adsuefactus rex melior adscisceretur" 'Entregavam como reféns os filhos dos reis exactamente com o objectivo de, no caso de se entediarem do governo da sua pátria, poderem apelar ao príncipe e ao Senado, para escolherem um rei melhor, afeito aos seus costumes'. Na discussão após a apresentação em Coimbra, Marc Mayer recordou que os reféns são um factor de romanização.

${ }^{10} \mathrm{O}$ imperativo económico, que se relaciona directamente com as questões da acessibilidade e da sociabilidade, ficou somente entrevisto, por exemplo em relação à Arábia, mas poderia rastrear-se através da ocorrência de lexemas como commercium, merces, navigare, navigatio, negotiator: Está implícita a desconsideração da necessidade de maior dominação territorial. 
pelo fácil acesso a todas as nações, pelas suas costas cheias de portos, pelo sopro benigno dos seus ventos.

Esses ideais deviam realizar-se em parte pela integração de um espaço itálico, europeu e ocidental, ao qual, sem necessário afã de conquista ou expansão, competia relacionar-se com outros povos e civilizações, tidos embora como não superiores ou até como inferiores, construindo uma só pátria (3.39-40). 


\title{
SUETÓNIO E O FASCÍNIO DO ORIENTE
}

\author{
José Luís Brandão \\ (Universidade de Coimbra)
}

\begin{abstract}
Suetonius doesn't set up in De uita Caesarum a explicit opposition between Eastern and Roman, but between good and bad behaviors. Nevertheless Eastern stereotypes such as despotism, corruption, voluptuous and effeminate conduct appear naturally represented in the public and private attitudes of the worst emperors. Some of them seem to promote a model of government that recalls the theocratic monarchy characteristic of Hellenistic tyrants. In spite of the gradual process of hellenisation in the aristocratic Roman classes, the extravagances of Caligula and Nero become unacceptable to the Roman mentality. In what concerns religion, the biographer distinguishes the ancient Greek cults, consecrated long ago by tradition, from the new importations, such as Egyptian, Judaic and Christian believes. So when Suetonius rejects the introduction of exotic habits he doesn't stress ethmic reasons but reveals a moralizing perspective based on ancestral Roman mores.
\end{abstract}

Falar do oriente, tomando como referência o ponto de vista romano, implica um conjunto de preconceitos ou generalizações que ficaram associados ao mundo helenístico, como despotismo, corrupção, vida fácil, opulência, voluptuosidade e costumes efeminados. Os imperadores têm de gerir o conflito entre a natural atracção pelo exótico e a rejeição de certos costumes, considerados decadentes, bem como o desprezo pelas monarquias helenísticas, inaceitáveis para a mentalidade republicana tradicionæi.

Suetónio não se preocupa em estabelecer explicitamente ưna oposição entre oriente e ocidente. Mas, nas Vidas dos Césares, são os piores imperadores que mais se aproximam dos conhecidos estereótipos orientais. Alguns príncipes manifestam comportamentos conotados com modelos de monar- 
quias teocráticas, afastando-se do projecto de Augusto. A tentação já vinha de trás. Marco António e Júlio César deixaram-se fascinar pelo Egipto e pelo culto que aí prestavam aos reis. Suetónio, como biógrafo, vê o problema, não tanto na dimensão política, mas sobretudo moral: o afastamento em relação ao mos maiorum. Ao desejar a condição de rei, o imperador manifesta inciuilitas e impotentia.

Júlio César repetia uma fala de Etéocles das Fenícias de Eurípides, com a qual sugeria que valia a pena violar a lei se fosse para satisfazer a ambição de reinar'. Na descrição dos factos que conduziram aos Idos de Março, isto é, das realizações e palavras que tornavam César merecedor da morte², são incluídas honras excessivas (o consulado ininterrupto, a ditadura perpétua, a prefeitura dos costumes e o praenomen de imperator; o cognomen de Pater Patriae e uma estátua entre as dos reis) e privilégios que ultrapassam a dimensão humana - humanum fastigium - (trono de ouro, estátuas entre os deuses, altares, leito divino, um culto com sacerdotes, o nome de um mês). No cúmulo da gradação, Suetónio apresenta a convicção de que o ditador pensava mudar a residência para Alexandria ou para Tróia. Além disso, corria o boato de que iria ser proposto, em reunião do senado, atribuir-lhe o título de rei, porque se afirmava nos livros sibilinos que só um rei poderia vencer os Partos (Jul. 79.3). Atacar este povo, para tirar a desforra de Carras, era um dos projectos de César que a morte veio cercear (Jul. 44.3).

Outro césar, também de nome Gaio, Calígula, apresenta um percurso semelhante, mas mais aparatoso: mostra aspirar a uma realeza de tipo oriental,

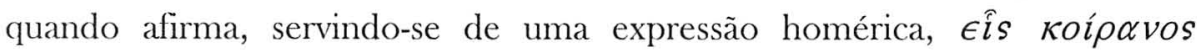
$\epsilon ́ \sigma \tau \omega, \epsilon \hat{i} s \beta \alpha \sigma \imath \lambda \epsilon u ́ s$ " «'haja um só chefe, haja um só rei!'»). Tal atitude figura à cabeça da parte da biografia em que se descreve o monstrum (Cal. 22.1ss). Suetónio confirma que pouco faltou para Calígula colocar o diadema' e transformar a species principatus em regni forma. E - acrescenta o biógrafo

'Jul. 30.5. Cl. Eurípides, Ph. 524. Suetónio apresenta a versão latina de Cícero (off. 82): Nam si uiolandum est ius, 〈regnandi〉 gratia / uiolandum est: aliis rebus pietatem colas. Vide CANFORA, L. 2000, 153.

"Jul. 76.1. Pracgrauant tamen cetera facta dictaque cius, ut et abusus dominatione et iure caesus existimetur: (...) et ampliora etiam humano fastigio.

"Cal. 22.1. As palavras são de Ulisses (II. 2.204-205). Calígula abandona o modelo augustano e volta-se para o cesariano: vide HurLliy, D. W. 1993, 85.

'Originalmente, uma tira branca usada pela família real persa, que se tomou depois na principal marca da realeza helenística: vide WARDLL, D. 1994, 205. 
- quando lhe fizeram notar que já ultrapassara a dimensão dos imperadores e dos reis, tratou de arrebatar a majestade divina (Cal. 22.2). No cúmulo destes excessos surge o estranho facto de, em noites de lua-cheia, convidar a lua para vir dormir com ele (Cal. 22.4.) ${ }^{6}$, e de se mostrar arrogante para com Júpiter que, segundo dizia, até o convidava para o seu contubernium (Cal. 22.3).

As excentricidades descritas nesta Vida tendem a ser interpretadas por parte da historiografia moderna à luz de um tipo de monarquia teocrática à maneira egípcia, que unia realeza e divindade em vida, modelo a que Calígula aderia, assumindo mais a descendência de Marco António que a de Augusto? Alguns autores vêem na apóstrofe à lua um aproveitamento hostil de um ritual associado ao culto de Ísis, em que o imperador se identificava com o Sol (Osíris)". A imitação dos príncipes Lágidas, que casam com as suas irmãs, pode explicar a relação incestuosa com Drusila e as honras que lhe concede depois da morte (Cal. 24.1-2) - uma imagem do casamento divino de Ísis e Osíris. Sintomático destas aspirações de Calígula parece ser o projecto, semelhante ao de César, de se transferir para Alexandria (Cal. 4.9.2)".

A mudança da capital para uma província será um medo comum aos habitantes da metrópole dos impérios. Também consta que Nero, em vias de perder o poder em Roma, chega a sonhar com uma dominatio no oriente

"Verum admonitus et principum et regum se excessisse fastigium. Note-se o paralelo com Jul. 76.1 .

"Motivo que Camus encarece e repete, dando-lhe o valor simbólico do impossível a que Calígula aspira. Cl. S'TRAıtss, W. A. 1951, 165; Gil.lis, J. 1974, 401. Várias são as tentativas de explicação, resumidas no com. de WARDLE, D. 1994, 214-215.

' Neste sentido parece ser entendida a proibição de festejar as vitórias de Áccio e da Sicília, como funestas (Cal. 23.1). LAmbrlichTS, P. 1953, 219-232, acentua a política oposta a Augusto e a afirmação da descendência de António, através da ideologia egipcizante. Vide Martin, R. 1991, 331-332; Guastellia, G. 1992, 159; Colin, J. 1954, 394-416. Mas a alirmação da herança de António não pode ser considerada contra Augusto, porque está bem documentado um escrupuloso cumprimento do culto ao fundador do principado.

"Ísis aparece associada à lua em Apuleio, Met. 11.3-6. Nesta perspectiva, Calígula, nas suas aspirações a uma monarquia de tipo egípcio, poderia muito bem estar a identificar-se com o sol (Hélios / Osíris), que tem comércio com a sua irmã, a lua (Selene / Ísis). Crê-se que Calígula tinha uma capela isíaca no seu palácio. Vide Clisusliscu, P. 1973, 277; Col.in, J. 1954, 408; LAMIBRECHTS, P. 1953, 226-228 e n. 2.

'Boato levantado certamente a partir da projectada viagem a Alexandria, referida por Flávio Josefo, $A J$ 19.81. Calígula parece seguir os passos do pai, Germânico, que fizera uma viagem ao Egipto: cf. Tácito, Ann. 2.59.1). Segundo Fílon (Leg. 162), Calígula mantinha boas relações com os habitantes de Alexandria e considerava aquela cidade como a única adequada para consagrar a sua divinização (Leg: 338). Vide GuAsTTiLla, G. 1992, 261. 
(Nero 47.2), ou o governo do Egipto (Nero 47.2). O desejo de Nero de substituir o nome de Roma pelo de Nerópolis (Nero 55) pode ser comparado com a prática da fundação de cidades por parte dos reis helenísticos ${ }^{10}$. Se, no oriente, a mudança de nome das cidades era uma forma de honrar o imperador, como já acontecera em relação a Augusto (Aug: 60), em Roma seria algo impensável.

Apesar de os Flávios se afastarem da tendência orientalizante, Domiciano reclama a majestade divina ao dizer que recebeu de novo a mulher no leito sagrado (puluinar); aceita o tratamento de dominus, certa vez no anfiteatro (Dom. 13.1), atribui-se, ao ditar uma carta, o título de dominus et deus, inaugurando o hábito de assim o apelidarem oficialmente"; não consentia que lhe erigissem estátuas no Capitólio, senão em ouro e prata ${ }^{12}$ e de um peso determinado.

A progressão para a dominatio ou regmum torna-se uma afronta para o povo romano, que só se curva perante a lei e que há muito considera um imperator romano acima dos reis". Dominatio e dominus têm conotações servis: daí que seja necessário distinguir entre princeps e imperator, por um lado, e dominus ou tyrannus por outro". Mas a diferença entre princeps e dominus não é de natureza constitucional, mas sobretudo moral. À inpotentia de César, que lhe valeu a morte, opõe-se a moderatio de Augusto.

Suetónio não diz, com Augusto ( $R G .7 .2)$, que este se tornou princeps senatus - expressão politicamente correcta, oriunda da tradição republicana ${ }^{1.5}-$,

\footnotetext{
10 Tácito, Annn. 15.40.3, fala do desejo de fundação de uma nova cidade e conecta o facto com o incêndio de 64 .

"Dom. 13.2. Díon Cássio, 67.13.3-4, conta o caso de Juvêncio Celso que, acusado de conspiração, salva a vida por tratar Domiciano por senhor e deus.

${ }^{12}$ Estátuas de ouro e prata erigidas em público significavam para os romanos divinização, permitida somente por imperadores como Calígula, Nero, Domiciano, Cómodo e Caracala: vide JoNEs, B. W. 1996, 110.

"Vide Grimal, P. 1993, 16; Gascout, J. 1984, 721-722.

"Bradli:y, K. R. 1991, 3715-3716. Nota Gascot, J. 1984, 721-722, que, neste ponto, Suctónio está de acordo com Plínio, Pan.45.3: Scis ut sunt diuersa natura doninatio et principatus, ita non alïs esse principen gratiorem quam qui maxime dominum grauentur:

${ }^{13}$ Suetónio não tem ilusões de que Augusto in retincnda [sc. re p.l perseuerauit (Aug. 28.1.) e contradiz assim a alirmação de $R G 34.1$ : rem publica cx mea potcstate in senatus popult Romani arbitrum transtuli. Em Cal.22.1, fala de species principatus, demonstrando assim ter consciência de que o nome de princeps, e, por consequência, principatus, é uma forma hábil de iludir os legalistas. Suetónio é realista: aceita a inevitabilidade do principado e a impossibilidade do retorno ao regime republicano.
} 
antes prefere acentuar que se trata da fundação de um regime verdadeiramente novo. O êxito fica a dever-se ao distanciamento em relação a César: a recusa de templos nas províncias, se ao seu nome não fosse associado o de Roma, e definitivamente na urbe; a fusão e dedicação a Apolo Palatino das estátuas de ouro que lhe erigiram; a recusa da ditadura ( $A u g$ : 52$)$ e sobretudo o horror à «maldição e desonra» do apelido de dominus (Aug: 53.1) ${ }^{16}$ e o respeito pelo senado - atitudes apresentados como documenta da ciuilitas (Aug. 51.1). A presença desta virtude no príncipe evita a progressão para uma monarquia teocrática, à maneira oriental, ou para uma tirania (dominatio), que cercearia a libertas, entendida, no império, como liberdade de expressão, prerrogativa que Augusto mostra respeitar (Aug. 54) $)^{18}$.

Também Cláudio revela ciuilitas ao recusar o praenomen de imperator e honras excessivas (Cl. 12.1) ${ }^{19}$. Tibério, na fase boa do principado, revela ciuilitas, ao recusar maximi honores que incluíam culto divino (Tib. 26.1) ${ }^{20}$, ao rejeitar o praenomen de imperator, o cognomen de pater patriae, a coroa cívica no vestíbulo da sua casa, ao limitar o uso do nome de Augusto, que the pertencia por herança, às cartas dirigidas aos reis (Tib. 26.2), e sobretudo ao recusar o apelido de dominus (Tib. 27), e ao defender repetidamente a liberdade de expressão e de pensamento $(\text { Tib. 28) })^{21}$ e, numa manifestação de respeito pelas instituições republicanas, chega mesmo a restabelecer uma species libertatis (Tib. 30) ${ }^{22}$.

O modelo que inspira mais desejo de emulação é, naturalmente, Alexandre Magno. Júlio César, questor na Hispânia, chora por ainda não ter feito

"Domini appellationem ut maledictum et obprobrium semper exhorruit. Suetónio não denuncia a habilidosa simulação de horror.

"Clementiae ciuilitatisque cius multa et magna documenta sunt. A ciuilitas, a par da clementia, vem associada, em Suetónio, à moderatio, como demonstra Gascot, J. 1984, 722-723.

${ }^{14} \mathrm{Nec}$ ideo libertas aut contumacia fraudi cuiquam fiut.

"At in semet augendo parcus atque ciuilis praenomen Imperatoris abstinuit, nimios honores recusauit.

${ }^{20}$ Verum liberatus metu ciuilem admodum inter initia ac paulo minus quam priuatum egit. Ex plurimis maximisque honoribus praeter paucos et modicos non recepit.

${ }^{2}$ Sed et aduersus conuicia malosque rumores et famosa de se ac suis camina lirmus ac patiens subinde iactabat 'in ciuitate libera linguam mentemque liberas esse debere'.

"Quin etiann speciem libertatis quandan induxit conseruatis senatui ac magistratibus et maiestate pristina et potestate. Também Tácito, Ann. 1.77.3, fala de simulacra libertatis. 
nada de grandioso, apesar de ter a idade em que o macedónio já dominava o mundo (Jul. 7.1); Augusto presta homenagem no Egipto ao corpo do herói (Aug: 18.1) e usa a sua imagem como sinete (Aug: 50). Se estes factos não envolvem censura da parte do biógrafo, a inclusão na indumentária da couraça de Alexandre (Cal.52) já é encarada como uma extravagância de Calígula. O mesmo se diga do penteado de Nero (Nero 51), considerado por alguns comentadores uma imitação do de Alexandre ${ }^{21}$. $\mathrm{O}$ facto de Tito, à semelhança do que fez Alexandre, venerar o boi Ápis em Mênfis e se cingir com o diadema agrava a suspeita de que quereria usurpar o poder ao próprio pai e tornar-se rei do Oriente, pelo que o príncipe se apressa a regressar a Roma para desmentir tais rumores (Tit. 5.3 $)^{25}$.

Realmente o país do Nilo continuava a revelar-se perigoso: um insurrecto poderia tomar este território como base de aç̧ão - tal foi, segundo Suetónio, o motivo pelo qual César não converteu o Egipto em província romana e o confiou ao governo de Cleópatra (Jul. 35.1) $)^{26}$. Vespasiano é aclamado pela primeira vez pelas legiões do Egipto e só depois pelas da Judeia (Ves. 6.4. ${ }^{27}$. O grau de certeza do poder (firmitas imperii) deste imperador é confirmado no templo de Serápis, onde lhe são miraculosamente oferecidos dons rituais que parecem assimilá-lo aos soberanos tradicionais do Egipto (Ves. 7.1) notícia baseada certamente na propaganda flaviana ${ }^{28}$.

É ainda na boca de uns marinheiros de Alexandria que o biógrafo coloca o tributo universal à obra pacificadora de Augusto, sob a forma de uma ceri-

${ }^{23}$ Díon Cássio, 59.17.3, diz que Calígula usou a couraça de Alexandre na travessia da ponte de Baias.

${ }^{21}$... ut comam semper in gradus formatam peregrinatione Achaica etiam pone uerticem sunnmiserit. Semper é um claro exagero do biógrafo. É consonante com a efígie da cunhagem de 64. Outra explicação é que se assemelha ao de um busto de auriga contemporâneo de Nero: daí que fosse tão escandaloso para um romano. Vide BRADLliY, K. R. 1978, 284-285.

${ }^{2 i} \mathrm{O}$ comportamento de Tito no Egipto insere-se na perspectiva da imitação, por parte dos Flávios, de Alexandre Magno no Egipto (Cf. Plutarco, Alex. 26-27). Também este visitou Mênfis, venerou o Boi sagrado (Arriano, 3.1.4) e, segundo uma tradição popular, terá sido investido como rei do Egipto. Vide Hlinrichs, A. 1968, 60.

${ }^{26}$ Ao contrário de outros autores (Tito Lívio, Per: 112; Plutarco, 49.10; Díon Cássio, 42.35 e 42.44; Apiano, 2.13.90) Suetónio, mais favorável ao ditador, não associa o facto à paixão de César por Cleópatra. Vide GASC()(t, J. 1984, 38-42.

${ }^{27}$ Cf. Tácito, Hist. 2.79. A versão de Josefo, BJ 4.601, segundo a qual Vespasiano foi aclamado na Judeia, é unanimemente rejeitada pelos autores modernos como falsa e tendenciosa. Vide Clisa, M. 2000, 64.

${ }^{24}$ Cf. Tácito, Hist. 4.82. Vide Hrinrichs, A. 1968, 61-65; ClisA, M. 2000, 68. 
mónia litúrgica, como se percebe pelo aparato e pelo ritmo da invocação (Aug. 98.2) ${ }^{200}$ :

Forte Puteolanum sinum praeteruehenti uectores nautaeque de naui Alexandrina, quae tantum quod appulerat, candidati coronatique et tura libantes fausta omina et eximias laudes congesserant: 'per illum se uiuere, per illum nauigare, libertate atque fortunis per illum frui'.

Quando atravessava, um dia, a baía de Putéolos, os passageiros e os tripulantes de um navio de Alexandria, que acabara justamente de aportar, vestidos de branco e coroados com grinaldas, não só the ofereceram incenso, como também o cumularam de bons auguírios e de extraordinários louvores: Por ele viviam, por ele navegavam; da liberdade e da felicidade por ele fruíam'.

O local onde se dá esta aclamação é centro de encontro entre o oriente e o ocidente, dada a forte influência helénica. É este o cenário escolhido por Calígula para a construção da ponte de barcas (entre Baias e Putéolos), extravagância que Suetónio coloca entre os espectáculos oferecidos por este imperador $^{30}$, mas que parece simbolizar o desejo de rivalizar com monarcas orientais. Uma das explicações aduzidas pelo biógrafo patenteia o desejo de emulação da ponte que Xerxes lançou sobre o Helesponto (Cal. 19.3)". Tanto mais que, no desfile, o príncipe ostentava (prae se ferens) o pequeno Dario, um refém parto, filho de Artábano III (Cal. 19.2 $)^{32}$.

A tensão das relações com os Partos (cf. Tib. 9.1) levava a demonstrações de força e jogos de influência. Mas, de modo semelhante à história da

${ }^{29}$ Segundo RoCCA-Si:Rra, G. 1974, 671-680, podemos perceber a expressão de um credo religioso e político que retoma um dos temas da propaganda de Augusto (a paz universal e a segurança dos mares) e que subentende a assimilação do príncipe a Júpiter, como causa última. O texto provirá de uma fonte em grego de origem egípcia, talvez Asclepíades de Mendes, citado em Aug. 94.4. Para Blinari(), H. W. 1975, 84, é um exemplo da afeição e aprovação generalizada do Império à obra de Augusto e à estabilidade do governo proposta em Aug: 28.2.

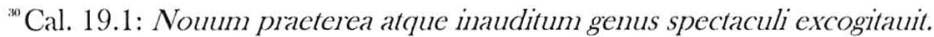

"Cf. Heródoto, 4.83 ss.

"2 Para LUGAND, R. 1930, 9-13, a presença do jovem parto é a chave para entender a mensagem deste cortejo apoteótico. Os Partos imolam cavalos ao Sol, cuja quadriga atravessa diariamente os céus. Sobre a ponte, Calígula identifica-se com o Sol. Esta cavalgada é a antecipação da apoteose a que está destinado depois da morte, em que acompanhará a viagem do Sol imortal. 
ponte de Baias, é como um espectáculo que Suetónio relata, na Vida de Nero, a recepção e coroação de Tiridates da Arménia (Nero 13.1-2), sem se deter na importância estratégica do controlo daquele estado-tampão ou no longo processo diplomático e militar que antecedera a cerimónia. Desse sucesso, protagonizado por Corbulão (personagem que Suetónio omite), resta apenas uma breve referência: o acto simbólico de fechar as portas do templo de Jano, a concluir a performance do imperador-histrião:

Non immerito inter spectacula ab eo edita et Tinidatis in urbem introitum ret<t>ulerim. Quem Armeniae regem magnis pollicitationibus sollicitatum, cum destinato per edictum die ostensurus populo propter nubilum distulisset, produxit quo oportunissime potuit, dispositis circa fori templa armatis cohortibus, curuli residens apud rostra triumphantis habitu inter signa militaria atque uexilla. Et primo per deuexum pulpitum subeuntem admisit ad genua adleuatumque dextra exosculatus est, dein precanti tiaralm] deductalm] diadema inposuit, uerba supplicis interpretata praetorio uiro multitudini pronuntiante; perductum inde in theatrum ac rursus supplicantem iuxta se latere dextro conlocauit. Ob quae imperator consalutatus, laurea in Capitolium lata, Ianum geminum clausit, tamquam nullo residuo bello ${ }^{33}$.

Não é sem fundamento que contarei entre os espectáculos a entrada de Tiridates na Urbe. Depois de convidar este rei da Arménia com grandes promessas, viu-se obrigado a adiar o dia que, através um edicto, destinara para o exibir ao povo, visto o tempo estar nublado, mas apresentou-o no momento mais oportuno que pôde. Dispostas as coortes armadas à volta dos templos do foro, sentou-se numa cadeira curul, junto dos rostra, com vestes triunfais entre insigmias militares e estandartes. Primeiro recebeu o rei, que subiu uma plataforma inclinada e se ajoelhou, e, depois de o ajudar a levantar com a mão direita, beijou-o. Em seguida, a pedido dele, tirou-lhe a tiara e colocou-lhe o diadema, enquanto as palavras do suplicante, traduzidas, eram proclamadas à multidão por um antigo pretor. Conduziram-no dali para o teatro e, renovadas as súplicas, colocou-o junto de si, ao seu lado direito. Saudado

${ }^{33}$ Esta recepção ocorreu no verão de 66. Há quem veja neste passo a ligação de Nero ao Mitraísmo: a cerimonia simbolizaria a coroação de Mitra pelo sol. Vide BRADLleY, K. R. 1978, 90. 
imperador por este facto, depois de levar uma coroa de louro ao Capitólio, fechou o templo de Jano bifronte, para significar que não havia mais guerras em suspenso.

Aparentemente, o show off atingiu os objectivos, a julgar pelo apoio que um falso Nero granjeou ainda entre os Partos, decorridos vinte anos após a morte deste imperador (Nero 57.2).

A opção pela análise caracterológica leva o biógrafo a retomar estes dois episódios na parte negativa das referidas Vidas, para os considerar numa perspectiva diversa. A história da ponte de Baias vai ser invocada para demonstrar a saeuitia e prepotência de Calígula, que precipita no mar os que estavam na margem (Cal. 32.1), e a recepção a Tiridates ilustra a luxuria de Nero, ruinosa para o erário público (Nero 30.2).

Envergar vestuário estrangeiro é indigno de um cidadão. $O$ vestuário patrius e ciuilis é a toga, cujo uso Augusto procurara incentivar (Aug: 40.5). Tibério é censurado por, em Rodes, trocar o patrius habitus pelo pallium e pelas sandálias gregas (crepidae) (Tib. 13.1). Calígula manifesta total desrespeito na forma de trajar (Cal. 52):

Vestitu calciatuque et cetero habitu neque patrio neque ciuili, ac ne uirili quidem ac denique humano semper usus est.

Nas roupas e no calçado e no restante trajar não usou o tradicional do seu país, nem o habitual dos cidadãos, nem sequer masculino $-e$, $\mathrm{em}$ suma, nem humano.

A descrição das suas roupas e adornos revela gostos orientalizantes, efeminados e monárquicos, de que é exemplo a degradante seda (sericatus), proibida por Tibério ${ }^{34}$. Fazendo jus à sua alcunha, Calígula parece interessar-se por calçado exótico. Usa peças orientais, que, em Roma, só têm lugar no palco: as sandálias e socos (crepidae, soccl); o coturno (usado pelos reis helenísticos) sinal de tirania. No cúmulo da gradação figura a já referida couraça de Alexandre Magno ${ }^{3 .}$.

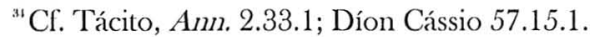

${ }^{*}$ Sobre o vestuário deste imperador, vide Wardele, D. 1994, 336-341; Hurlli, D. W. 1993, 186-189.
} 
Ao ostentar atributos divinos, Calígula parece estar a imitar o seu bisavô Marco António, que, no Oriente, se apresentou como Dioniso ${ }^{36}$, embora também conste que Augusto se disfarçou de Apolo num banquete secreto (Aug: 70.1-2). Ao empunhar o raio, imitando Júpiter, Calígula parece seguir os passos de Alexandre ${ }^{37}$ e outros monarcas. $\mathrm{O}$ uso do tridente e do caduceu, numa imitação de Neptuno e Mercúrio, também tem antecedentes. O facto de Calígula se travestir de Vénus não se apresentará tão estranho se se tiver em conta que a identificação com divindades masculinas ou femininas era comum no culto helenístico do rei: os precedentes incluem Alexandre. Suetónio, no entanto, ao inserir estes factos na rubrica do vestuário, não lhes atribui outro significado que extravagâncias exibicionistas. Não se devem descartar as tendências teatrais deste imperador.

Entre as seduções do oriente, contam-se, como é sabido, rainhas famosas. O biógrafo relega-as para o âmbito da vida sexual dos biografados. Quanto à bem conhecida relação de César com Cleópatra, Suetónio, separa-a da questão política, para a integrar na esfera da vida privada $(J u l .52 .1)^{38}$, colocando a tónica no tipo de vida que passaram juntos, com contornos mais orientais que romanos: os banquetes até à alvorada, a viagem pelo Nilo, as dádivas, a instalação da rainha em Roma, o reconhecimento do suposto filho comum.

$\mathrm{O}$ facto de António incluir no testamento os filhos que tivera da rainha Egípcia é usado por Augusto como prova de que o seu opositor se distanciara do mos ciuilis (Aug. 17.1). Por outro lado, o biógrafo alonga-se muito mais a descrever o suicídio de Cleópatra e os esforços vãos de Augusto para a conservar viva até ao triunfo (Aug: 37.4) do que a narrar a batalha de Áccio, referida apenas como vitória definitiva sobre António (Aug: 17.2). Também a relação com Berenice é integrada na análise da libido de Tito (Tit. 7.1), pelo que o afastamento da amante, contra a vontade de ambos, é considerada uma louvável mudança no comportamento do príncipe, operada ao assumir o governo do império (Tit. 7.2 $)^{39}$.

${ }^{3 i}$ Cr. Veleio Patérculo 2.82.4; Díon Cássio 48.39.2; Plutarco, Ant. 24.3.

${ }^{3 \prime}$ Que assim foi representado por Apeles (Plutarco, De Iside 24) e em cunhagens na Babilónia.

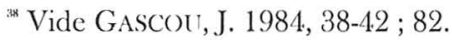

${ }^{30}$ Cf. Flávio Josefo, AJ 18.5.4; 19.5.1; 20.7.3; Tácito, Hist. 2.2.1; Díon Cássio, 66.15.3-4. Berenice regressará depois a Roma (cf. Díon, 66.18.1). Esta ruptura dramática teria motivações políticas. Acontece na altura da execução de Cecina e Marcelo, dois senadores que conspiraram contra Vespasiano, o que provocou atritos na relação com o senado. Tito foi provavelmente 
A tirania sexual manifesta-se sobretudo no abuso de matronas romanas. Mas se é censurável a sedução de mulheres nobres casadas por parte de César e Augusto "1), o tom de reprovação torna-se mais intenso na descrição do ultraje às matronas ilustres, por parte de Tibério", que provoca o suicídio de Malónia, por parte de Calígula, que as examinava mercantium more ${ }^{12}$, e por parte de Nero, que organizava orgias em que grandes damas imitavam as taberneiras (Nero 27.3). É ainda imputada a este último a violação da vestal Rúbria (Nero 28.1).

A situação torna-se mais gravosa quando se trata de homens. O biógrafo não estabelece com rigor a distinção entre realidade e invectiva política. O rumor de que César, na juventude, se prostituiu a Nicomedes da Bitínia (Jul.2) há-de acompanhá-lo para toda a vida (Jul. 49.1), como provam os versos dos soldados no triunfo (Jul. 49.4). O próprio visado, em reposta humorada a uma insinuação, se compara a Semíramis, a famosa rainha assíria (Jul. 22). A relação com um monarca oriental é, assim, o primeiro de uma série de comportamentos homossexuais dos Césares", de modo que soa a excepção dizer que Cláudio se abstinha de homens (Cl. 33.2). Mas a prática sexual passiva (impudicitia) é sobretudo característica dos tiranos: enquanto absolve Augusto e Tito, Suetónio permite que esta acusação fique para sempre ligada a César ${ }^{15}$, Calígula ${ }^{46} \mathrm{e}$ Nero ${ }^{17}$.

pressionado por Vespasiano a afastar Berenice, para pacificar os senadores descontentes. Esta ambiciosa rainha do Oriente levantaria problemas e faria pensar em uma nova Cleópatra. Vide Rogirs, P. 1980, 94; MARTin, R. 1991, 150-151.

${ }^{10}$ Jul. 50.1: Pronum et sumptuosum in libidines fuisse constans opinio est, plunimasque et illustres feminas corrupisse; Aug. 69.1: condiciones quaesitas per amicos qui matres familias et adultas aetate uirgines denudarent atque perspicerent, tanquam Toranio mangone uendentc.

"Tib. 45: Feminarum quoque, et quiden illustrium, capitibus quanto opere solitus sit inludere (...).

${ }^{12}$ Cal. 36.2.

"O rumor, imediatamente seguido da referência a feitos notáveis que lhe valeram a coroa cívica na tomada de Mitilene, faz BaLdDwin, B. 1983, 222, pensar no topos helénico do guerreiro valoroso e sodomita.

"Jul. 49; Aug. 68; Tib. 44.2; Cal. 36.1; Nero 28.2-29; Gal. 22; Otho 2.2; Tib. 3.2; Vit. 12; Tit. 7.1; Dom. 1.1. Provavelmente resultado da influência da cultura helénica na alta sociedade romana. Vide Waldacl-Hadrill, A. 1984, 184.

${ }^{1}$ "Jul. 2: non sine rumore prostatae regi pudicitiae; 49.1: Pudicitiae eius famam nihil quidem praeter Nicomedis contubennium laesit; cf. 52.3: a impudicitiae infamia.

"Cal. 36.1: Pudicitiae <neque suae> neque alienae pepercit.

"Nero 29: Suam quidem pudicitiam usque adeo prostituit... 
O último dos Júlio-Cláudios representa o grau mais elevado da degradação moral de um tirano. Além do casamento farsesco com o eunuco Esporo (Nero 28.1), com emprego do flammeum, Nero entrega-se a jogos indecentes, em que ele próprio faz de mulher (Nero 29):

Suam quidem pudicitiam usque adeo prostituit ut contaminatis paene omnibus membris nouissime quasi genus lusus excogitaret, quo ferae pelle contectus emitteretur e cauea uirorumque ac feminarum ad stipitem deligatorum inguina inuaderet et, cum affatim desaeuisset, conficeretur a Doryphoro liberto; cui etiam sicut ipsi Sporus, ita ipse denupsit, uoces quoque et heiulatus uim patientium uirginum imitatus'.

Prostituiu a tal ponto o seu pudor que, depois de contaminar quase todos os membros, inventou como que um jogo completamente novo, segundo o qual, coberto com uma pele de animal selvagem, se lançava de uma jaula e atacava os órgãos sexuais de homens e mulheres atados a um poste e, depois de se fartar de tais sevícias, era possuído pelo seu liberto Doríforo, a quem serviu de noiva, como Esporo a ele próprio, e chegou mesmo a imitar os gritos de sofrimento das virgens ao serem forçadas.

Estas notícias têm sido consideradas por alguns autores como possíveis interpretações falseadas, intencionalmente ou não, de cultos orientais levados a cabo por Nero'.

A baía de Neápolis era o centro de helenização e de luxúria. Calígula e Nero faziam "cruzeiros" de luxo por estas paragens, o que implicava prostitui-

"Vide Vlirdik̀re, R. 1975, 19-20; com. de Bradlit, K. R. 1978, 164-165; Cizlik, E. 1982, 41-42; Martin, R. 1991, 160 e 169-171; Firnándiz Urili P. 1994, 111-124.

"Díon Cássio 63.13.1, fala da semelhança de Esporo com Popeia Sabina. O ritual do casamento tem sido visto como uma cerimónia de iniciação numa religião mistérica: Esporo teria sido castrado, porque era servidor de Cíbele. O flammeum é também o véu do iniciado. Talvez se tratasse, de facto, de uma iniciação, em que Esporo, pela sua união matrimonial com Mitra, acedia ao título de nymphus. Quanto a Nero 29, crê-se que este Doríforo e o Pitágoras que figura no relato de Tácito, Ann. 15.37.4, e Díon Cássio, 63.13.2, sejam a mesma pessoa e que se trataria, como no caso de Esporo, de um casamento místico, em que Nero scria o iniciado. Doríforo não era o nome próprio, mas a função que desempenhava: ministro do culto de Cíbele ou da deusa Ma-Belona. Vide Vlirdil̀rl, R. 1975, 19-22; com. de BradLli, K. R. 1978, 161-165; CIzl:K, E. 1982, 41-42; MARTIN, R. 1991, 171. 
ção de matronas romanas (Nero 27.2) e enorme dispêndio de dinheiro (Cal. 37.3). A arte erótica estava na moda nesta zona. A descrição do retiro de Tibério na ilha de Cápreas (Tib. 43) sugere uma deturpação moralizante dos gostos artísticos do imperador:

Secessu uero Caprensi etiam sellaria excogitauit, sedem arcanarum libidinum, in quam undique conquisiti puellarum et exoletorum greges monstrosique concubitus repertores, quos spintrias appellabat, triplici serie conexi, in uicem incestarent coram ipso, ut aspectu deficientis libidines excitaret. Cubicula plurifariam disposita tabellis ac sigillis lasciuissimarum picturarum et figurarum adonnauit librisque Elephantidis instruxit, ne cui in opera edenda exemplar impetratae schemae deesset. In siluis quoque ac nemoribus passim Venerios locos commentus est prostantisque per antra et cauas rupes ex utriusque sexus pube Paniscorum et Nympharum habitu, quae palam iam et uulgo nomine insulae abutentes Caprineum dictitabant.

No seu retiro em Cápreas, inventou ainda um quarto com divãs, sede das suas lascívias secretas, no qual, bandos de moças e rapazes pervertidos, recolhidos de toda a parte, e os inventores de monstruosas uniões, aos quais chamava spintriae, encadeados em grupos de três, se pudessem prostituir alternadamente à sua frente, para que, ao olhar, ele excitasse os seus desejos em declínio. Adornou alcovas, dispostas em vários sítios, de quadros e estatuetas com pinturas e esculturas de extrema devassidão e guarneceu-os de livros de Elefầntis, para que a ninguém faltasse, ao executar o serviço, o modelo da atitude exigida. Também, nas matas e nos bosques, teve a ideia de distribuir, por aqui e por ali, sítios para os prazeres de Vénus e, por antros e grutas, os que se prostituíam, de entre a juventude de um e outro sexo, em traje de pequenos Pãs e Ninfas. Por esta razão, às claras e jogando publicamente com o nome da ilha, repetidas vezes lhe chamavam 'capríneo'.

$\mathrm{Na}$ colecção privada do imperador contava-se, portanto, literatura erótica, como os livros de Elefântis (Tib. 43.1), poetisa grega licenciosa ${ }^{30}$, e representações obscenas, como um quadro de Parrásio (Tib. 44.2), pintor

so A ela alude também Marcial, 12.43.4. 
efésio do V-IV século a.C. Por detrás da uituperatio adivinha-se a afeição por arte grega. A referência ao quadro, onde se representa comércio sexual entre Atlas e Meleagro ${ }^{\text {s1 }}$, mostra-se coerente com a grande paixão de Tibério por temas mitológicos pouco comuns (Tib. 70.3). Além disso, os antros dispersos pelos bosques, onde jovens Pâs e Ninfas se prostituíam entre si (Tib. 43.2), integram-se num gosto de influência helenística por grutas decoradas, de que é também exemplo a Spelunca da Campânia, onde Tibério sobreviveu a um desabamento (Tib. 39) $)^{\text {s. }}$.

Suetónio escreve num tempo em que estava bastante adiantado o processo de helenização da sociedade romana. Os imperadores são instruídos nas letras gregas, sinónimo de erudição e cultura superior, e fazem-se rodear de eruditos helénicos. Júlio César, na juventude, dirige-se a Rodes para assitir às lições do orador Apolónio Mólon (Jul. 4.1). Ele próprio se preocupa com a educação do seu herdeiro, Octávio: envia-o a Apolónia para se dedicar por inteiro aos estudos (Aug. 8.2). Tibério, em Rodes, procurava lições de filósofos (Tib. 11.3).

Percebe-se, através da leitura das Vidas dos Césares, um progressivo cultivo da língua helénica, que vai do nível familiar ao da linguagem literária. Júlio César exprime-se em grégo, mas o uso que faz desta língua parece

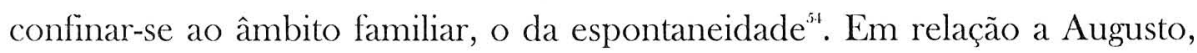

"... in qua Mcleagro Atalanta orc morigeratur - «no qual Atlas c Meleagro se satisfaziam sexualmente com a boca um ao outro", se aceitarmos a tradução de morigerari no scu sentido médio-passivo de 'estimulação mútua', como propõe HallukT, J. P. 1978, 196-200. Pode bem acontecer que o interesse de Tibério por arte erótica, aliada à especulação sobre as suas actividades em Cápreas, gerasse a tradição hostil que o representa como um pervertido sexual. Vide LINDSAY, H., 1995, 142.

${ }^{52} \mathrm{Na}$ gruta de Sperlonga, descoberta em 1957, os quatro maiores grupos escultóricos encontrados têm como protagonista Ulisses em situações que ilustram as diversas facetas do scu carácter: pietas para com Aquiles, dolus para com Diomedes, uirtus na luta com Cila, calliditas ao cegar Polifemo. Se tivermos em conta o estilo e os temas e o gosto de Tibério (como se lê em Tib. 70), e a semelhança entre o carácter de Ulisses e Tibério, ambos propensos à dissimulação, STlwarT, A. F.1977, 76-90, sugere a possibilidade de as esculturas serem da iniciativa de Tibério, quando da sua retirada para a Campânia.

${ }^{33}$ Vide Wallace-Hadril., A. 1984, 181-185.

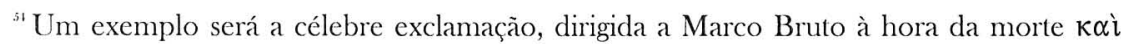

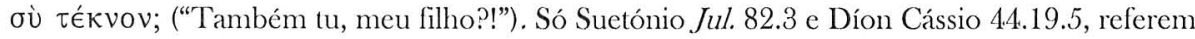
estas palavras. Dificilmente Bruto seria filho de César. Em 85 a.C, data provável do nascimento de Bruto, César teria apenas 16 anos, e a relação com Servília situa-se muito mais tarde. Mas o 
para além do seu gosto pelas letras gregas (Aug: 89), chega-nos a notícia de alguns versos improvisados (Aug. 98.4) e da adaptação da cláusula de comédia com que o fundador do principado se despede da vida (Aug. 99.1). Tibério, embora se exprima em grego com desenvoltura, procura, no entanto, evitar esta língua nas sessões do senado e nos documentos oficiais (Tib. 71). Tais escrúpulos são ultrapassados por Cláudio, que, além de ser um apaixonado pelas letras gregas (Cl. 42.1), não hesita em responder em grego aos embaixadores e coloca este idioma no mesmo plano do latim (uterque sermo noster). Tito, que fora educado na corte de Cláudio juntamente com Britânico, revela grande facilidade em discursar e compor poemas nas duas línguas (Tit. 3.2). Além disso, nas Vidas dos Césares abundam citações em grego que denunciam a sólida cultura homérica dos Césares ${ }^{55}$.

Um exemplo interessante do processo de helenização é a introdução da música no curriculum de estudos. Se, no tempo em que Cornélio Nepos escrevia o seu Epaminondas, cantar e dançar eram actividades consideradas indignas que colidiam com a grauitas romana ${ }^{56}$, com o hábito, acabaram por ser toleradas e até cultivadas pelas classes elevadas. Tito é elogiado por saber cantar e dançar (Tit. 3.2), Britânico tinha talento suficiente para provocar a inveja de Nero (Nero 33.2), este último fora instruído na música entre outras disciplinas (Nero 20.1), Calígula mostra paixão pelo canto e pela dança (Cal. 54.1), e, de modo especial, pela pantomima (Cal. 55.1): chega a convocar senadores a meio da noite para o verem dançar (Cal. 54.2). O problema

termo tékvov, primariamente de uso trágico e épico, é empregado como afectuoso desde Homero (II. 9.437; Od. 4.611), o que não acontcce com filius latino. Muitos jovens latinos, educados por preceptores helénicos, aprendem o grego como primeira língua. Esta torna-se, assim, para os jovens romanos das classes superiores, a língua da espontancidade. Outras fontes referem palavras gregas pronunciadas no momento do assassínio (Plutarco, Caes. 66.8). Por isso, Duiblisson, M. 1980, 881-890, defende que estas palavras, inseridas num comportamento linguístico definido, devem ser autênticas; e se não são mencionadas pela maior parte dos historiadores é porque não têm interesse para a história política.

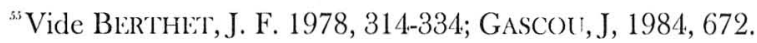

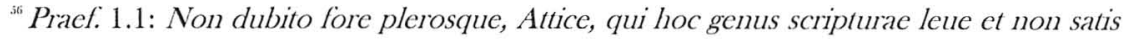
dignum summorum uirorum personis iudicent, cum relatum legent, quis musicam docuerit Epaminondam aut in eius uirtutibus commemorari, saltasse eum commode scienterque tibiis cantasse. Epam.1.1-2: Epaminondas, Polymnï filius, Thebanus. De hoc priusquam scribimus, haec praecipienda uidentur lectoribus, ne alienos mores ad suos referant, neue ca, quae ipsis leuiora sunt, pari modo apud ceteros fuisse arbitrentur. Scimus enim musicen nostris moribus abesse a principis persona, saltare uero etiam in uitiis poni: quae omnia apud Graecos et grata et laude digna docuintur: Vide Tupun, C. 1979, 124-142; Git A, M. A. 1990, 536-537. 
coloca-se quando o imperador de amador se transforma em profissional, ao ponto de dar mais importância a estas modas que ao governo do império ou de manchar a dignidade imperial com estas actividades.

A dedicação de Nero às artes cénicas e às corridas do circo é colocada na parte negativa da Vida, entre os probra. O imperador faz a sua estreia, como actor, em Neápolis, em ambiente grego (Nero 20.2), importa de Alexandria a ideia de uma claque de jovens, os Augustanos (Nero 20.3), e só depois, fingindo ceder aos rogos do povo, se apresenta em Roma (Nero 21.1), nos Neronia, festival à moda grega por ele mesmo criado ${ }^{57}$.

Apesar da progressiva preparação das mentalidades e da adulação de que foi alvo, Nero confessa que solos scire audire Graecos solosque se et studiis suis dignos («só os Gregos sabem ouvir e só eles são dignos de si e da sua arte» $)^{58}$ e empreende uma viagem à Acaia, para participar e vencer em todos os jogos gregos (Nero 22.3). Entre os exageros do imperador, conta-se o facto de correr em Olímpia com um carro puxado por dez cavalos (Nero 24.2), extravagância que ele próprio tinha, em um poema, censurado a Mitridrates. Pelo seu regresso, celebra um triunfo, não o de um general vitorioso, mas o de um actor (Nero 25.1-2.):

Reuersus e Graecia Neapolim, quod in ea primum artem protulerat, albis equis introüt disiecta parte muri, ut mos hieronicarum est; simili modo Antium, inde Albanum, inde Romam; sed et Romam eo curru, quo Augustus olim triumphauerat, et in ueste purpurea distinctaque stellis aureis chlamyde coronamque capite gerens Olympiacam, dextra manu Pythiam, praeeunte pompa ceterarum cum titulis, ubi et quos quo

${ }^{37}$ Cf. Nero 12.3. Já Augusto tinha instituído jogos gregos, mas em Neápolis. Como nota Warmington, B. H. 1999, 39, neste festival, instituído em 60, Nero não participou pessoalmente nas provas de retórica e poesia latina (Tácito, Ann. 14.21.4) nem de lira (Díon Cássio, 61.21.2), mas, apesar disso, os prémios foram-lhe atribuídos. Na repetição dos Neronia, em 65, o senado oferece-lhe antecipadamente os prémios, para evitar o escândalo de um imperador vestido de histrião (Tácito, Ann. 16.4), mas Nero insiste em participar em igualdade de circunstâncias. Cl. Cizlik 1982, 126-127. GrifFin, M. T. 1984, 114, afirma que foi a impaciência de Nero que o impediu de vencer as resistências dos mais conservadores. A sua performance pessoal tornou mais difícil a conversão das classes elevadas.

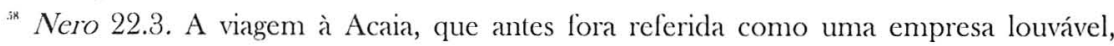
sobretudo devido às obras de abertura de um canal no istmo de Corinto (Nero 19.2), aparece agora como objecto de censura, devido aos motivos que a determinaram. Vide GAscoU, J. 1984, 369-370. 
cantionum quoue fabularum argumento uicisset; sequentibus currum ouantium ritu plausoribus, 'Augustianos militesque se triumphi eius' clamitantibus. Dehinc diruto circi maximi arcu per Velabrum forumque Palatium et Apollinem petit. Incedenti passim uictimae caesae sparso per uias identidem croco ingestaeque aues ac lemnisci et beillaria. Sacras coronas in cubiculis circum lectos posuit, item statuas suas citharoedico habitu, qua nota etiam nummum percussit".

Regressado da Grécia, fez uma entrada, com cavalos brancos, em Neápolis - porque ali tinha pela primeira vez revelado a sua arte -, depois de abatida parte das muralhas, como é costume para os vencedores dos jogos sagrados. Entrou de modo semelhante em Ancio, depois no território de Alba, depois em Roma. Mas, em Roma, usou o mesmo carro de que Augusto outrora se servira no seu triunfo e uma veste de púrpura e uma clâmide adornada com estrelas de ouro e uma coroa olímpica na cabeça e a pítia na mão direita. Precedia-o o cortejo solene das restantes coroas, com inscrições a indicar onde, a quem e com que arğumento de canto ou de peças teatrais vencera. Seguia o carro a claque a gritar; segundo o ritual das ovações, que eram 'os augustianos e os soldados do seu triunfo'. Em seguida, demolido que fora um arco do Circo Máximo, dirigiu-se, através do Velabro e do Foro, para o Palatino e para o templo de Apolo. À sua passagem, imolavam-lhe vítimas por toda parte, espalhavam continuamente açafrão pelas ruas e ofereciam-Ihe aves e fitas e guloseimas. Dispôs as coroas sagradas pelos quartos, à volta dos leitos, e ainda estátuas suas em traje de citaredo, imagem com a qual fez ainda cunhar moedas.

Os mais tradicionalistas, entre os quais se contam sobretudo os membros do senado, suportam mal o facto de serem governados por um histrião e por um auriga, desonra apresentada pelo biógrafo como uma das motivações dos revoltosos envolvidos nas conjuras de Pisão e de Vinício ${ }^{60}$.

\footnotetext{
${ }^{39}$ Descrição semelhante figura em Díon Cássio, 63.20.1ss.

${ }^{60} \mathrm{Cf}$. Nero 36.2: Nonnulli etiam imputarent, tamquam aliter illi non possent nisi morte succurrere dedecorato llagitiis omnibus'. Suetónio está a generalizar: aquelas palavras, segundo Tácito, Ann. 15.68.1, foram pronunciadas somente por Sulpício Áspero. Díon Cássio, 62.24.2, diz que outro conjurado, Súbrio Flávio, acrescenta que não podia ser escravo de um citaredo e de um auriga.
} 
De qualquer modo, é preciso distinguir o lado culturalmente bom da helenização do aspecto decadente. Neste particular, cabe aos Flávios alguma reaç̧ão ao helenismo no sentido da depuração ${ }^{61}$. Aproveita-se o que tem de positivo - incentiva-se a literatura e as artes (Ves. 17-19); Domiciano cria mesmo um festival à moda Grega, musical equestre e gímnico (Dom. 4.4) -, mas rejeita-se o luxo e a libertinagem sexual (Ves. 11). Vespasiano granjeia fama de avarento pela sua parcimónia. Controlam-se os banquetes longos e dispendiosos (Tit.7.2; Dom. 21); os pantomimos, símbolos de licenciosidade, ficam confinados a palcos privados (Dom. 7.1), e um questor é expulso do senado por excessiva afeição aos pantomimos e à dança (Dom. 8.3); reprimese o adultério e a homossexualidade (Dom. 8.3-4) e entrava-se a criação de eunucos através da proibição da castração (Dom. 7.1). Do louvor destas medidas ressalta um saudosismo da austeridade romana ${ }^{62}$.

Por outro lado, é preciso separar a influência grega, pouco a pouco tolerada e cultivada pela elite romana, das influências orientais propriamente ditas. No que respeita à religião, tal distinção é clara para o biógrafo. O desprezo da religio e dos deuses tradicionais é comum aos tiranos ${ }^{63}$. Suetónio mostra-se, neste campo, favorável à restauração do mos maiorum e contrário à introdução de cultos estrangeiros, à excepção dos helénicos.

$\mathrm{O}$ modelo de referência continua a ser Augusto. Este imperador e Cláudio são louvados pelo seu papel de restauradores de antigas práticas religiosas itálicas (Aug. 31.4) $)^{61}$ e, no que concerne aos cultos estrangeiros, são aplaudidos pela preocupação de respeitarem só os antigos e consagrados pela

${ }^{61}$ Vide Wallack-Hadril.l, A. 1984, 186-189.

${ }^{62}$ As medidas contra o excesso de luxo são louvadas em César (Jul 43); Tibério (Tïb. 34.1); em Vespasiano (Ves. 11) e mesmo em Nero, na fase positiva do principado (Nero 16.2.).

a. César não mostrava temor religioso, não fazia fé nos presságios (Jul. 59) e mostra-se arrogante para com os harúspices (Jul 77) e, nos idos de Março, entra na cúria spreta religione (Jul. 81.4); Tibério apresenta-se circa deos ac religiones neglegentior (Tib. 69.1); Calígula despreza os deuses (Cal. 51.1); Nero é religionum contenıtor (Nero 56), Vitélio, ao entrar em Roma e ao assumir o cargo de pontífice máximo, despreza todo o direito divino e humano (Vit. 11.1) e incendeia o templo de Júpiter no Capitólio; Domiciano venera Minerva superstitiose (Dom. 15.3).

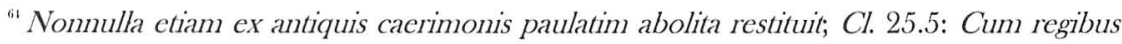
foedus in foro ile/cit porca caesa ac uetere fetialium pracfatione adhibita. Domiciano, na parte favorável do principado, é louvado pelo facto de restabelecer o velho costume de reprimir os incesta das vestais (Dom. 8.3) e punir as ofensas aos deuses (Dom 8.5). 
tradição e desprezarem os restantes, de acordo com a distinção estabelecida na Vida de Augusto ${ }^{6.3}$ : em relação aos ritos antigos e consagrados, o fundador do principado inicia-se nos mistérios de Elêusis (Aug: 93), culto que Cláudio pensou mesmo em transferir para Roma $(C l .25 .5)^{66}$; no que diz respeito aos outros cultos, Augusto menosprezou o do boi Ápis no Egipto e a religião judaica (Aug: 93); Cláudio expulsa os judeus, chefiados pelo impulsor Chrestus (Cl. 25.4) ${ }^{67}$. Suetónio coloca na parte positiva da Vida de Nero a perseguição aos cristãos, porque se tratava de genus hominum superstitionis nouae ac maleficae (Nero 16.2)68, e na parte aceitável da Vida de Tibério a perseguição aos cultos egípcios e judaicos e aos astrólogos (Tib. 36). Porque é tradicionalista ${ }^{69}$, Suetónio não aprecia aquelas novidades e considera-as superstições. Condena a Nero o culto da Deusa Síria (Atargátis) e de uma pequena imagem de uma donzela (alia superstitio) (Nero 56); a Otão, o culto de Ísis, sintomático do carácter efeminado deste imperador (Otho 12.1).

A rejeição de cultos estrangeiros em Roma não tinha a ver com descrença efectiva, mas com o intuito de preservação dos costumes romanos. Com efeito, Suetónio dá crédito a presságios orientais (entre outros) ligados ao advento de Vespasiano ao trono imperial: um profecia judaica de carácter messiânico divulgada em todo o oriente (Ves. 4.5$)^{70}$; o oráculo do deus do Carmelo $^{71}$ e uma profecia de um cativo Judeu, de nome Josefo (Ves. 5.6 ( $^{72}$.

\footnotetext{
${ }^{\circ}$ Peregrinarum caerimoniarum sicut ueteres ac praeceptas reucrentissime coluit, ita ceteras contemptui habuit.

${ }^{66}$ Esta medida aparece em oposição (indicada por contra) aos outros cultos proibidos por Cláudio.

${ }^{67}$ Alguns autores identificam este Chrestos com Cristo, admitindo uma anacronia (Cristo foi crucificado no tempo de Tibério), pois os primeiros cristãos não se distinguiam, em Roma, dos Judeus. Outros pensam que se trataria de um agitador judeu em Roma. Cf. Gascou, J. 1984, 731 n. 114.

${ }^{6 *}$ Tácito, Annl. 15.44.2-5, embora hostil aos cristãos, considera-os bodes expiatórios apresentados por Nero, quando se levantaram rumores sobre a culpa do imperador no incêndio. $\mathrm{O}$ historiador acha exagerado o castigo e diz que os condenados suscitavam a piedade, por serem vítimas da crueldade de Nero.

${ }^{69}$ Cl. GASC()U, J. 1984, 732.

${ }^{70}$ Percrebruerat Oriente toto uetus et constans opinio esse in factis ut eo tempore Iudaea profecti rerum potirentur: Id de imperatore Romano, quantum postea euentu paruit, praedictum Iudaei ad se trahentes rebellarunt. Tambėm Tácito interpreta esta profecia como concernente a Vespasiano e Tito (Hist. 5.13.2).

"Cf. Tácito, Hist. 2.78.3, que afirma que o nome do sacerdote era Basílides.

${ }^{72}$ Cf. Díon Cássio, 66.1, e o próprio cativo, Flávio Josefo, BJ 3.8.2.
} 
Adverso a toda a divinização do imperador em vida, Suetónio mostra-se céptico em relação à apoteose dos imperadores: dá uma explicação naturalista para a de César $(\hbar u l .88)^{73}$; expressa subtil ironia ao referir-se à de Augusto (Aug. 100.4.4); dá crédito aos gracejos de Vespasiano sobre a sua própria apoteose (Ves. 23.4).

Portanto, a parte oriental do império parece constituir um modelo para os tiranos, a sua base de apoio e a esperança de refúgio, no caso de perderem o poder em Roma. Com os Flávios é diferente: Vespasiano levanta-se do oriente, mas, ao assumir o poder, mantém-se fiel aos costumes romanos.

Suetónio, na linha da tradição romana, tende a ver com reserva a introdução de hábitos orientais por contrastarem com os costumes dos antepassados. A cedência de alguns césares a hábitos exóticos não é tomada em termos de confronto de civilizações, mas avaliada do ponto de vista da oposição virtudes/vícios. A imitação de tiranos helenísticos não é admitida porque se opõe à ciuilitas e à libertas, princípios segundo os quais o cidadão só se submete à lei. O princeps não deve elevar-se acima do lugar que lhe cabe como primeiro dos cidadãos.

Nesta perspectiva moralizante, mesmo certos costumes gregos e manifestações de filelenismo, se são tolerados em cidadãos privados, tornam-se sintoma de degradação moral quando adoptados pelo príncipe na sua vida pública. Os bons imperadores são os que, na linha de Augusto, zelam pela pureza de costumes, reprimindo a introdução de hábitos espúrios, e que, pela sua justiça e moderação no trato com as nações estrangeiras, conquistam a amizade dos povos distantes, como os da Índia e da Cítia (Aug. 21.3). Em Suetónio, o fundador do principado aparece mais como pacificador e unificador do mundo do que como vitorioso sobre o oriente.

33 (...) stella crinita per septem continuos dies fulsit exoriens circa undecimam horam, creditumque est animam esse Caesaris in caelum recepti; et hac de causa simulacio eius in uertice additur stella.

"Nec defuit uir praetorius, qui se effigiem cremati euntem in caelum uidisse iuraret. 


\section{Bibliografia}

BAldwin, B. 1983, Suetonius. Amsterdam, Hakkert.

Blinario, H. W. 1975, "Augustus princeps" : ANRWII. 2. 75-85.

BerThlit, J. F. 1978, "La culture homérique des Césars d'après Suétone" : REL 56 314-334.

Bradley, K. R. 1978, Suetonius' Life of Nero. An historical commentary, Bruxelles, Latomus.

— 1991, "The imperial ideal in Suetonius' Caesares": ANRWII, 33, 5 3701-3732.

CANFora, L. 1970, "Cesare continuato" : Belfagor 25 419-429.

Cliausliscu, P. 1973, "Caligula et le legs d'Auguste": Historia 22 269-283.

Clsa, M. 2000, Svetonio. Vita di Vespasiano, Bologna, Cappelli.

CIzlk, E. 1982, Néron, Paris, Fayard.

Colin, J. 1954, "Les consuls du césar-pharaon Caligula et l'héritage de Germanicus" : Latomus $13394-416$.

Dubuisson, M. 1980, "Toi aussi, mon fils!": Latomus 39 881-890.

Gascou, J. 1984, Suétone historien, Paris, de Boccard.

Gil...ss, J. 1974, "Caligula. De Suétone à Camus" : LEC 42 393-4.03.

GIUA, M. A. 1990, "Aspetti della biografia latina del primo impero" : RSI 12 535-559.

Grifrin, M. T. 1984, Nero. The end of a dynasty, London, Routledge.

Grimal, P. 1993, O Império Romano, trad. portuguesa, Lisboa, Ediçōes 70.

Guastlilla, G. 1992, Gaio Svetonio Tranquillo, La vita di Caligola, [testo, trad. e comm.] a cura di -, Roma, La Nuova Italia Scientifica.

Hallet, J. P. 1978, "Morigerari. Suetonius, Tiberius, 44." : AC47 196-200.

Henrichs, A. 1968, "Vespasian's visit to Alexandria" : ZPE 3 51-80.

Hurley, D. W. 1993, An historical and historiographical commentary on Suetonius'Life of C. Caligula, Atlanta, Scholars Pr.

Jonks, B. W. 1996, Suetonius. Domitian, ed. with intr., com. and bibl. by -, London, Bristol Classical Press.

LAmisRechTS, P. 1953, "Caligula dictateur littéraire" : BIBR 28 219-232.

Lindsay, H. 1995, Suetonius, Tiberius edited with intr., com. and Bibliography by -, London, Bristol Classical Press.

Lugand, R. 1929, "Suétone et Caligula" : REA 31 9-13.

Martin, R. 1991, Les douze Césars: du mythe à la réalité, Paris, Les Belles Lettres.

Rocca-Slirra, G. 1974, "Une formule cultuelle chez Suétone (Divis Augustus, 98,2)" : Mélanges de philosophie, de littérature et d'histoire ancienne offerts à P. Boyancé. Rome, Palais Farnèse, 671-680.

R()GlRs, P. 1980, "Titus, Berenice and Mucianus": Historia 29 86-95. 
STlWART, A. F. 1977, "To entertain an emperor. Sperlonga, Laokoon, and Tiberius at the dinner table" : JRS 67 76-90:

Stratiss, W. A. 1951, "Albert Camus' Caligula. Ancient sources and modern paralels": CompLit 3 160-173.

Tupusn, C. 1979, "Nepos and the origins of political biography" : Studies in Latin literature and Roman history ed. by Diroux, C., Bruxelles, II, 124-161.

Vl:RDIl:RL:, R. 1975, "À verser au dossier sexuel de Néron" : PP30 5-22.

Wallack-Hadril.t, A. 1984, Suetonius. The scholar and his Caesars, New Haven (Conn.) Yale Univ. Pr.

Warduli, D. 1994, Suetonius'Life of Caligula. A conmentary, Bruxelles, Latomus.

Warmington, B. H. 1999, Suetonius Nero, text, with intr. \& notes by -, Bristol Class. Pr. (2a ed.). 


\title{
VISÕES DA ESCRAVATURA NA LITERATURA LATINA
}

\author{
Cláudia Amparo Teixeira \\ Universidade de Évora
}

\author{
Paulo Sérgio Ferreira \\ Universidade de Coimbra
}

\begin{abstract}
Starting with the legal context of roman slavery, this study intends to analyse how the Latin literature (technical, theatrical, gallant, satyrical, philosophical, moral, romanesque and epigrammatic) reflects the reality as well as the new laws that were meanwhile created. The perspective how slavery is presented in Latin literature shows a large diversity, depending on the angles that transmit an idea about reality, and angles that, symbolically, repudiate and invert reality itself.
\end{abstract}

Em 2004 celebrou-se o ano internacional da luta contra a escravatura. Um dos pontos altos desse percurso da humanidade foi a Declaração Universal dos Direitos do Homem, proclamada pela Assembleia Geral da ONU a 10 de dezembro de 1948, e onde, no artigo 1ํㅗ se consagra: «Todos os seres humanos nascem livres e iguais em dignidade e em direitos. Dotados de razão e de consciência, devem agir uns para com os outros em espírito de fraternidade."

Apesar dos bons propósitos subjacentes a esta proclamação, a realidade está bem longe dos objectivos por ela pretendidos. Além de, em muitos países, a abolição legal se ter dado muito tempo depois desta data, a verdade é que ainda hoje, numa Europa desenvolvida, ouvimos falar de trabalho infantil e exploração da imigração ilegal.'

'V., a propósito, http://migrantes.no.sapo.pt/pagef.EmigPortEsc.html, onde se pode ler o seguinte título: "Emigrantes portugueses vítimas de racismo e escravatura em países da União Europeia." 
Esta tensão entre as declarações de princípios e a realidade actual não se verificava na Antiguidade, porque as primeiras, enquanto proclamações gerais, abstractas e que se pretendem universais, são uma conquista moderna; e a segunda, isto é a situação concreta dos escravos, era perfeitamente traduzida e enquadrada pelo sistema jurídico romano.

Não nos debruçaremos pormenorizadamente sobre este assunto, na medida em que tal já foi feito por António Santos Justo, em "A situação jurídica dos escravos em Roma”, mas, para o nosso propósito, importa, desde já, reter as seguintes ideias:

a) Do ponto de vista patrimonial o seruus era uma res, como uma casa, um campo, um animal, ou um objecto inanimado. Logo, o escravo não podia dispor de bens ou ter um património."

b) Desprovido de capacidade jurídica, o escravo não dispunha de liberdade, cidadania e família. ${ }^{3}$

c) O seruus não tinha capacidade processual, ou seja, não podia «ser parte num processo nem como demandante nem como demandadon.'

No entanto, contrariamente ao que sucedia noutras sociedades, assistia ao escravo a possibilidade de através da manumissio passar da condição de

"SAnTos Justo (1983) 134.

"SAntos Justo (1983) 136.

' SAntos Justo (1983) 137. Na mesma página, o autor refere, porém, que «já na época clássica, o escravo podia queixar-se contra homens livres em situações graves e excepcionais, servindo-se das accusationes, e havia, ainda, situações não definidas e ilimitadas em que, por motivos de ordem pública, o imperador autorizava ut seruos de dominis querentes praefectus audiat. Porém, as decisões tomadas nestas espécies de querelae e expostulationes eram simples medidas de polícia, nunca sentenças no sentido próprio do termo. Nào suscitaram, nos jurisconsultos, a necessidade de ser reconhecida capacidade processual.»

"SAntos Justo) (1983) 140, n.35, explica que "As formas de manumissio previstas iure ciuile eram: a manumissio uindicta, a manumissio censu e a mamumissio testamento. Nào previstas pelo ius ciuile, mas sugeridas pela actividade do pretor, eram as manumissiones feitas inter amicos, per conuiüi adhibitionem ou per mensam; e per epistulam. (....) Uma forma especial de manumissão pertence à época cristã, tendo sido reconhecida por Constantino: é a manumissio in sacrosanctis ecclesïs. Em todas estas manumissiones não previstas iure ciuile, o pretor apenas impedia o manumissor de, como dominus ex iure Quinitium, reivindicar o escravo. O seruus continuava juridicamente escravo, não podendo $\mathrm{em}$ consequência, testar c revertendo os bens, à sua morte, para o antigo dominus, como se fosse pecúlio.» Idem, n.33, observa que «Para um escravo se tornar livre e "ciuis romanus» era necessário que o manumissor fosse dominus ex iure Quiritium; por isso a manumissio feita pelo proprietário in bonis não atribuía a libertas.» 
escravo à de liberto (situação que ocorria, muitas vezes, fruto da possibilidade de o escravo constituir um pecúlio, e, desta forma, reunir fundos para comprar a sua liberdade) e, assim, adquirir o status libertatis, bem como o direito de participar na cidadania (status ciuitatis) e, no tocante à família, o status familiae. Neste caso, estabelecia-se uma nova ordem jurídica que não desobrigava, no entanto, o antigo escravo de determinados deveres em relação ao seu antigo senhor (agora seu patronus), entre os quais o obsequium, «que impedia o libertus de instaurar uma aç̧ão criminal ou infamante contra o patrono e de o demandar com outra actio sem permissão do magistrado; as operae (que se traduziam na prestação de alguns serviços, nomeadamente a administração de bens, o cuidar dos filhos do patrono, etc.) e os bona (dever de prestar alimentos em caso de necessidade). E, como se não bastasse, o patrono (ou os seus filhos mesmo impúberes, a quem a tutela legítima se transmitia à sua morte) era o tutor do liberto, circunstância que, só por si, lhe permitia um "controlo" muito estreito, até mesmo sobre a vida íntima dos libertos. Manifesta-se, ainda esta dependência no facto de o liberto não ter nenhuma expectativa sucessória em relação ao patronus, que, todavia, é chamado a herdar os bens daquele na falta de filii in potestate.. ${ }^{6}$

As constantes tensões sociais em Roma e as progressivas transformações do império ainda conduziram à criação de leis que, sem terem posto em causa o estatuto jurídico dos escravos, visavam regrar e melhorar as difíceis relações entre servos e senhores e, deste modo, manter a ordem social vigente: "Assim, a lex Petronia (talvez do ano 19 d.C.) proibiu ao dominus a condenação do escravo ad bestias depugnandas (D. 48.8.11.2); Cláudio determinou que o escravo enfermo, abandonado no templo de Esculápio, adquiria a liberdade (D. 40.8.2); Antonino Pio dispôs que o dominus que assassinasse, sem razão o seu escravo, responderia como se fosse alheio o escravo assassinado (D. 1.6.1.2); Domiciano feriu com penas pecuniárias a castração dos escravos; Adriano proibiu o assassínio de escravos sem a pronúncia do magistrado e impediu-os de serem objecto de comércio para fins imorais. Com o advento do Cristianismo são introduzidas novas mitigações à condição servil: atribui-se maior importância às uniões conjugais entre escravos (sem, todavia, serem equiparadas ao matrimónio); proibiu-se o constrangimento duma escrava a prostituir-se ou a participar em espectáculos teatrais.» ${ }^{7}$ E difícil ter uma ideia

"SAntos Justo (1983) 14.1-14.2.

'SANTOS Justo (1983) 139, n.32. 
precisa sobre a eficácia de tais decretos junto de uma população que, na sua grande maioria, tinha níveis de instrução baixíssimos ou praticamente nulos, mas a literatura grega sobre a sociedade romana e a literatura latina permitemnos fazer uma abordagem, ainda que limitada, deste problema.

Entre as sociedades que não possibilitavam ao escravo a compra da alforria, contava-se a grega, mas, no que à situação dos servos dizia respeito, a Grécia não serve a Roma de termo de comparação: se, dos números propostos por S. Lauffer para a população ateniense de 430 a.C. (30.000 cidadãos, 120.000 familiares, 50.000 metecos e 100.000 escravos), já Rocha-Pereira disse que «sofrem de uma imprecisão de base, pois assentam num cálculo do número de escravos puramente conjectural e alteram-se completamente, se outros elementos nos demonstrarem que grande parte dos habitantes de Atenas não possuía qualquer escravo, mas vivia apenas do seu trabalho; ${ }^{8}$ já, no que toca a Roma, sustenta Alföldy que não há motivos para pôr em causa a teoria de P. A. Brunt, que, baseada em Políbio 2.24.3ss., calcula que, em 225 a.C., por exemplo, a população da península itálica, excluindo o norte, rondaria os 3.000.000 de homens livres e os 2.000.000 de escravos. ${ }^{9}$ Para este número - e não nos podemos esquecer que a escravatura por dívidas tinha sido abolida pela lex Poetelia Papiria de 326 a.C., havia, portanto, mais de um século - terão contribuído não apenas os uerna, ${ }^{10}$ filhos nascidos das uniões entre escravos, mas também as sucessivas conquistas expansionistas de Roma. A título de exemplo, valerá a pena recordar que, de acordo com Lívio 9.42.8, em 307 a.C., 7.000 aliados dos Samnitas tinham sido vendidos como escravos. Diodoro 23.9 e 18.15 informa-nos de que 25.000 habitantes de Agrigento

"Rocha-Plerlira (2003) 183. A investigadora remeteu para M. Austin - P. Vidal. NAQUlit, Économies et sociétés en Grèce ancienne, (Paris, ${ }^{2} 1972$ ) cap. I, e concluiu depois de ter invocado a autoridade de Heródoto 3.2.80-83, que afirmara que a maioria da população era constituída por pequenos comerciantes, marinheiros, lavradores, artesãos, bem como a de Xenofonte, Memoráveis 4.2.37, que considerara demos os pobres, dentre os cidadãos: "Notese, de passagem, como são excluídos deste grupo da população, não só os escravos, como também os metecos, e como a designação de cidadão é independente da categoria censitária.» Em 184-5, Rocha-Pereira ainda alega que Alcidamante, um Sofista grego, do séc. IV, foi o primeiro a proclamar a igualdade natural entre escravos e homens livres (cf. Aristóteles, $R h$. $1.1373 \mathrm{~b})$ e que Platão, em República, colocou mulheres e homens em pé de igualdade para o desempenho das mais altas tarefas da Polis.

"Apud AlFöldDY (1989) 46.

${ }^{10}$ Verna significa, à letra, "escravos nascidos em casa». 
chegaram ao mercado de escravos, o mesmo acontecendo com 13.000 prisioneiros de Panormo em 254 a.C. Na guerra contra Cartago, os Romanos fizeram, em 256 a.C. mais de 20.000 cativos e 55.000 foi o número resultante da destruição da cidade africana em 146.a.C."

A julgar pelo enquadramento jurídico referido, é de crer que a generalidade dos escravos teria, em Roma, uma vida muito difícil. Esta ideia é, de resto, confirmada por Plutarco, que, de Catão, um ilustrativo exemplo do pater familias tradicional, nos diz o seguinte ${ }^{12}$ (Cat. Ma. 21.1 e 4: «Catão possuía numerosos escravos. Comprava sobretudo prisioneiros de guerra ainda pequenos e que se podiam criar como jovens cães ou potros. (...) Quando a sua situação se tornou importante e recebia amigos e colegas, punia com o chicote, imediatamente depois do repasto, os escravos culpados de qualquer negligência no serviço ou na preparação do banquete. Preparava-se sempre para armar discussão e desavença entre os seus escravos, pois desconfiava e receava a sua grande inteligência. Se um escravo era suspeito de ter cometido um crime merecedor de morte, julgava-o e, se fosse reconhecido culpado, executava-o diante de todos os domésticos.»

Esta prática, decorrente do direito absoluto de vida e de morte do senhor (ius utendi et abutendi) sobre os seus escravos, enquadra-se ainda numa economia de cariz marcadamente rural, baseada numa estrutura social onde o pater familias exerce absoluto poder sobre os seus dependentes. O testemunho de Plutarco acerca do comportamento de Catão para com seus escravos é confirmado pelas palavras do próprio, num tratado técnico intitulado De agri cultura: embora se sentasse à mesa com os servos, ${ }^{13}$ o próprio Catão recomendava que se não desse de comer a um escravo doente (Agr. 2.4: cum serui aegrotarint, cibaria tanta dari non oportuisse), porque não trabalhava, e que este fosse vendido bem como o escravo velho, juntamente com os outros excedentes ( $A_{g}$. 2.7). Nesta linha se justifica também o facto de, apesar da lei vedar aos escravos o direito de contraírem matrimónio ${ }^{14}$ e, consequentemente,

"BRADLEY (1994) 33.

${ }^{12}$ Citamos a partir de Plutarco, Vies, Tome V, Aristide-Caton l'Ancien - PhilopoemenFlamininus. Texte établi et traduit par Robert Flacelière et Émile Chambry. Paris, Les Belles Lettres, 1969.

"V. 1.17.

"SANTOS Justo (1983) 138, observa, no entanto, que embora o direito tenha recusado à união entre os escravos «a dignidade matrimonial, persistindo em considerá-la um facto puramente material - contubernium» -, contudo «a defesa da própria comunidade impunha ao ius o reconhecimento de algumas consequências dessas relações contubernais: os vínculos de 
os direitos de sucessão de cônjuges e filhos, os senhores incentivarem as uniões entre servos, com os intuitos de, como sustentam Varrão, R. 1.17.5 e 7, e Columela 1.8.4, fazerem dos parceiros e dos uerna penhores da fidelidade dos escravos e, deste modo, aumentarem ainda o número de servos e, correlativamente, o seu património. ${ }^{15}$ Se pensarmos que Catão viveu entre 234 e 149 a.C.; que as Res rusticae de Varrão foram publicadas na segunda metade do séc. I a.C.; e que o De re rustica de Columela remonta à segunda metade do séc. I d.C., constatamos que o modelo social arcaico se prolongou pela época imperial, o que significa que os escravos do campo não terão notado significativas melhorias na sua situação ao longo de todo aquele período. ${ }^{16}$

No entanto, é precisamente a estrutura familiar arcaica, nomeadamente a visão do tratamento que o pater familias deve dar aos seus dependentes, que vai ser adaptada por Cícero, no século I, em termos de teorização política, ao tipo de relação que o estado romano deve manter com os povos conquistados ou a conquistar. O Arpinate procura justificar a política expansionista romana à luz de uma societas generis humani, regida pelos princípios civilizacionais da Vrbs e em que ao não cumprimento desses princípios por parte dos submetidos corresponderia, de forma semelhante ao que sucedia na relação entre pater familias e escravo, uma sanção.

O testemunho de Plutarco ainda alude ao recurso do pater familias ao chicote e à morte como formas de castigo dos escravos. Este é um tópico recorrente na comédia, mas usado de um modo diverso, na medida em que, apesar de constantemente ameaçado com as chibatas, o moinho e as correntes, o servo, fazendo jus ao seu qualificativo plautino de callidus 'astuto', não só acaba por ficar isento dos castigos, como chega a triunfar sobre quem o

sangue, nascidos dessas uniōes - seruilis cognatio -, foram juridicamente reconhecidos para impedimentos matrimoniais de filhos dos escravos que entretanto tivessem adquirido liberdade; para regular a sucessão legítima dos escravos libertos; etc.»

is Teriam sido certamente as condiçōes de domínio em que viviam que estiveram na origem das várias revoltas, levadas a cabo por escravos. As mais importantes ocorreram na Sicília em 135-132 a.C., sob a chefia de Euno (a Este) e Cléon (a Oeste) e em 104-100 a.C., sob a liderança de Sálvio. Também a revolta de Espártaco (cujo exército chegou a contar com 120.000 homens), de 73 a 71 a.C., na Península Itálica, imortalizada por Stanley Kubrick no filme homónimo, foi significativa da importância que estas revoltas tiveram na época Republicana.

${ }^{16}$ V. Flirrlitra (1998). 
deseja punir. De toda a literatura latina que nos chegou, é, com efeito, no universo da comédia que o escravo adquire maior protagonismo e desenvolve uma formulação que se revela mais humanizada, devedora e credora de sentimentos, angústias, alegrias e dotada de pensamento abstracto, capaz de congeminar, entretecer, ajudar. Em comédias como Bacchides, Miles, Poenulus e Pseudolus, todas de Plauto, os respectivos escravos - Crísalo, Palestrião, Tóxilo, Mílfio e Psêudolo - desempenham um papel nuclear na condução da intriga. $\mathrm{O}$ caso porventura mais paradigmático do que acabamos de afirmar será o de Epídico, na peça homónima: consegue, por duas vezes - numa delas, sob a ameaça de moinho por parte do seu jovem senhor, Estratípocles ${ }^{17}$-, ludibriar o pai do rapaz e extorquir-lhe dinheiro para satisfazer os sucessivos caprichos amorosos do filho. Não quis a Fortuna que tanta audácia ficasse sem recompensa: descobertos os dolos do escravo e após longa caminhada pela cidade em busca de Epídico para o punir, Apécides e Perífanes, o pai do iuuenis enamorado, chegam ao palco e deparam com um Epídico que não tarda a estender-lhes as mãos, para que o segundo velho lhas amarre com as correias, e, mais ousado do que nunca, se diz merecedor da liberdade. Depois de se recrear com a ignorância dos velhos, o escravo diz ao pai de Estratípocles que vá dar uma espreitadela dentro de sua casa. Lá estava Teléstis, a escrava que, adquirida para Estratípocles, era afinal a irmã perdida do jovem e a filha de Perífanes e de Filipa. O velho acaba por prometer ao escravo uns borzeguins, uma túnica e uma capa, e o mais importante de tudo: a liberdade.

${ }^{17}$ STR. [...] Sed operam Epidici nunc me emere pretio pretioso uelim: / quem quidem ego hominem irrigatum plagis pistori dabo, / Nisi hodie prius comparassit mihi quadraginta minas, / quam argenti fuero elocutus ei postremam syllabam. (Epid. 120-3: «Estratípocles. - Mas para ter Epídico a trabalhar para mim... agora até pagava ouro en pó. Que esse tipo, ao menos ferrava com ele no moinho, bem ensopado de pảncada, se hoje mesmo me não arrebanhasse as quarenta minas - antes mesmo de eu lhe ter acabado de pronunciar a última sílaba da palavra dinheiro.») (Citamos a partir A. Ernotrt, Plaute, Conedies, T. III, Paris, Les Belles Lettres, 1965; a tradução é de W. S. Meidiriros, Plauto, Epídico, Coimbra, INIC, 1988.) Em 605-6, é Perífanes, pai do jovem, que, ao corrente dos embustes do servo, formula o seguinte propósito: Ego relictis rebus Epidicum operam quacrendo dabo. / Si inuenio, ixctiabilem ego illi faciam hunc ut fiat diem. "Eu deixo todos os negócios e vou-me entregar à caça de Epídico. Se o apanho... garanto que este dia há-de ver o fim da sua vida.» Em 684, Epídico desafia Perílanes a amarrar as suas mãos com as lora 'correias' que seriam usadas para castigar os escravos. Consciente de que seu filho, sob orientação do escravo, dissipara os seus bens, Teoprópides ameaça Tranião com o fogo (Mos. 1114) e com o madeiro (1133). Exemplos de outras ameaças encontram-se em Mil. 156s., 215s., Ps. 1099s., e Am. 1029, onde o general ameaça Mercúrio, que se encontra disfarçado de Sósia, escravo de Anfitrião. 
Assegurada a paparoca do futuro liberto, o escravo apenas deixa que o senhor o desamarre, mediante a súplica e um pedido de desculpas, de joelhos, deste. É o que acaba por acontecer. ${ }^{18}$

Neste sentido, «se, por um lado, a comédia é fruto de insurreição social, o certo é que também não deixa de ser um momento privilegiado de reconciliação do indivíduo consigo próprio, com a sociedade e com a rotina do quotidiano. Nessa medida, funciona como uma espécie de catarse para as classes sociais oprimidas. Tal como sucedia nas Saturnais, cada peça descreve uma sociedade às avessas, onde as classes inferiores alimentam a imaginação com o retrato de um mundo por elas idealizado. Terminado este interlúdio, tolerado e até fomentado pelas instituições dominantes, estas voltam a assumir, de forma opressiva, o comando dos destinos dessa sociedade. ${ }^{10}$

A experiência da liberdade saturnina dos escravos aparece, de resto, descrita por Horácio em S. 2.7: após um movimento de entronização, permitido por seu senhor, Davo acusa Horácio de inconstância (no campo deseja a cidade e na cidade deseja o campo), de incoerência (apregoa a frugalidade, mas nunca recusa convites para jantar em casa de Mecenas) e de devassidão (se ao escravo bastava uma cortesã, ao senhor... não!). Apenas as ameaças de apedrejamento, de trespasse com setas, de deportação para uma propriedade onde o trabalho é duro põem termo à invectiva do escravo e, deste modo, se configura o movimento de destronização típico das Saturnais.

Mas o pragmatismo, a astúcia e o sentido de oportunidade deste tipo de escravo haveriam de ter grande fortuna na concepção de personagens servis da arte europeia ocidental: pensamos concretamente nos serviçais das obras de autores como Gịl Vicente, Francisco Manuel de Melo e Molière; nos escravos da. commedia dell'arte; e das óperas cómicas de Mozart: As Bodas de Figaro (libreto de Beaumarchais) e Così fan tutte.

Também em Ovídio, o escravo, embora desprovido da dimensão psicológica que lhe confere Plauto, aparece numa vertente depurada e acomodada ao retrato da vida galante da alta sociedade e ao ambiente do constante entretecimento de teias amorosas lícitas e, sobretudo, ilícitas. Com efeito, o desempenho das funções de intermediário entre amante e amada fá-lo adquirir, fruto

\footnotetext{
${ }^{18}$ A propósito da cena final do Epidicus, escreve Medeiros (1981) 394: "Na comédia que Plauto amava tanto como a si próprio, Epídico é um pouco a sua imagem - a imagem do plebeu que, lutando por alcançar a independência económica, alcançou, do mesmo passo, com sortilégios da arte e da inteligência, o aplauso e a glória do seu tempo. E de todos os tempos.»

"Flirreira (1998) 61. A cena final é analisada por Mediriros (1981).
} 
da cumplicidade e do sigilo de que se torna credor, um estatuto utilitário, mas de uma condição bem distante da do escravo rural. Entre as várias estratégias de conquista do ente feminino, sugere o poeta a saudação personalizada, dirigida a cada um dos servos e servas que a rodeiam, bem como a oferta de pequenos presentes, despesa insignificante (Ars 2.252ss.). Se os escravos da amada constituem, numa primeira fase, um meio de aproximação, já, em caso de separação, tornam-se personae non gratae, dispensáveis e a evitar (Rem. 639-40). Mas o senhor também se pode servir do tratamento que dá a seus próprios servos para conquistar as boas graças da senhora: basta que, após decidir libertar um escravo ou perdoar-lhe uma ofensa, dê a entender à sua amada que o faz por intercessão desta (Ars 2.291).

Além de reflectir um paradigma social esclavagista ou de criar um mundo possível que inverte, ainda que apenas momentânea e inconsequentemente, essa realidade, a literatura não hesitou também em usar o vocabulário da escravatura em sentido metafórico e, deste modo, enriquecer o seu imaginário com a transposição daquele universo temático para outros campos, nomeadamente, o amoroso, o literário e sobretudo o moral. ${ }^{20}$

Entre os autores que recorreram à comparação com a situação dos escravos para descreverem um estado de espírito que se traduzia numa «subordinação obsessiva de indivíduos a paixões avassaladoras»," conta-se Ovídio. Nem o próprio Sulmonense ficou, de resto, imune a esta patologia, como atestam Am. 3.11. 3-4 e 9-15: após admitir que já tinha quebrado as correntes e já se tinha libertado do fogo que o consumia (Scilicet adserui iam me fugique catenas), o poeta recorda quanto penara por aquele amor e a vez em que, seruus ut 'como um escravo', dormira ao relento diante da casa da amada e, de manhã, vira sair o amante. Fedra, nos versos 611s. e 617 da peça homónima de Séneca, também diz ao alvo de sua paixão incestuosa, o enteado Hipólito, que a não trate por mãe, mas por irmã, ou, ainda melhor, lhe chame famula; e, depois de the oferecer o trono de Teseu, pede-lhe, em discurso relativamente ambíguo, que a tome por escrava.

A enunciada servidão de Ovídio e de Fedra em relação respectivamente à amada e ao enteado será semelhante àquela que, mais tarde, enformará a

\footnotetext{
${ }^{20}$ Convém lembrar que tal já se verificava na literatura grega: em Eurípides, Hipp. 424-5, por exemplo, Fedra sustenta que a coragem individual não resgata da escravidão o homem que vive na consciência das coisas vergonhosas praticadas pelos pais.

${ }^{21}$ Firrlitira (2001) 75.
} 
relação entre trovadores e suas amadas, bem como a de Camões com a cativa que o tinha cativo. ${ }^{22}$

Em outra acepção, emprega Horácio o vocabulário do domínio da escravatura para se referir aos poetas que de seus modelos copiavam os piores aspectos (Ep. 1.19.19), em clara alusão à falta de originalidade poética.

Mais expressiva, contudo, porquanto efectivamente ajustável às inquietações e cogitações de teor existencial sobre a condição humana, é a adaptação das ideias deste domínio ao campo moral. Este processo já se verificava em Cícero e em Horácio, ${ }^{23}$ mas é em Séneca que se torna mais recorrente: considera, com efeito, o Coro de cativas troianas do Agamemnon que uma vida é uma escravidão (cf. Dial. 9.10.3) e o suicídio, uma libertação (604ss.); Hipólito, uma das personagens da Phaedra, afirma que aquele que vive no cume das montanhas não é escravo do poder, nem o persegue, ou às honras vãs, ou às efémeras riquezas (490-1); em Ben. 7.28.4 e Dial. 12.10.5, critica Séneca os que são escravos do seu ventre; em $C l$. 1.8.1-3, sustenta o filósofo que o rei se deve privar de determinadas coisas pelo seu povo, pois esta é a escravidão honrosa; em Dial. 3.1.10.2, que vive em plena tirania quem se submete à servidão de alguma paixão; em Dial. 4.2.21.3, que se deve conduzir o espírito entre a liberdade e a servidão, para que se não degrade ou se não torne insolente; em Dial. 4.2.21.4, recomenda o filósofo que o espírito não sofra humilhação, ou servidão alguma; e seja benevolente; em Dial. 5.3.15.3, mantém o Cordovês que em qualquer escravidão, há sempre uma via para a liberdade, nem que essa via seja a derradeira possível: a morte (cf. Ep. 26.10). Assim, o colo, a garganta e o coração podem ser os meios para a libertação individual (Dial. 5.3.15.4). Em Dial. 7.3.3, a felicidade passa por utilizar os bens da fortuna sem se deixar escravizar por eles; em Dial. 7.4.4, a servidão corresponde

${ }^{2}$ Nas "Endechas a Bárbara escrava", escreve Camões: «Aquela cativa / que me tem cativo, / porque nela vivo / já não quer que viva.» Em comentário ao poema, chama Hernâni CiDADl: (Luís de Camões, Rimas, vol. III, Círculo de Leitores, ${ }^{10} 1984$, 485 n.42) a atenção para a distância que separa esta formosura oriental da de Laura, a amada de Petrarca. D. João Manulit, no Cancioneiro Geral, de Garcia de Rlsinde, também já cantara «uma escrava sua». À saga marítima e expansionista portuguesa, que permitiu ao homem do Renascimento o contacto com outras raças e culturas, se deve a adesão a estes novos padrões de beleza.

${ }^{27}$ De acordo com Cícliro, Rep. 3.39 fr. 2 (consultámos Esther Brégulet, Cicéron. La République. Paris, Les Belles Lettres, II, 1980, 72), do mesmo modo que o senhor domina os escravos, assim o espírito comanda o desejo: reprime-o e quebranta-o [cf. FirRlira (1999) 98-99]. Em S. 1.16, diz Horácio que o povo é escravo da fama; e, em Ep. 1.16.63, fala o poeta da submissão às paixões. Sobre o assunto, v. FERri:Ira (2000) $115 \mathrm{~s}$. 
à submissão aos prazeres e às dores do corpo; em Dial. 7.8.2, viver de acordo com a natureza corresponde, entre outras coisas, a não ser escravo do próprio corpo (cf. Ep. 14.1) ou dos bens alheios; segundo Dial. 7.14.2, os prazeres conduzirão a grandes desgraças e, cativos, cativarão; e, em Ep.8.7, Epicuro recomenda, com a aprovação de Séneca, que quem quiser alcançar uma verdadeira liberdade se torne escravo da filosofia. Para terminar, importa realçar que os passos referidos são apenas uma pequena amostra dos muitos em que Séneca recorre ao imaginário da escravatura para tratar problemas de ordem ética, e que as tragédias senequianas ilustram, em grande medida, os malefícios da submissão do indivíduo aos affectus.

Subjacente ao uso do léxico da escravatura na representação das paixões encontra-se, em Séneca, uma ética filosófica de carácter estóico. O filósofo considerava a condição de escravo um indiferente, isto é, algo que não depende directamente do indivíduo, mas que lhe é proporcionado pela sorte ou acaso e que, em si, não é moralmente bom nem mau. Assim devem ser entendidas as suas famosas palavras acerca do assunto, em Ep. 47.1: 'Serui sunt.' Immo homines. 'Serui sunt.' Immo contubernales. Serui sunt.' Immo humiles amici. 'Serui sunt.' Immo conserui, si cogitaueris tantundem in utrosque licere fortunae. «'São escravos.' Não, são homens. 'São escravos.' Não, são camaradas. 'São escravos.' Não, são amigos mais humildes. 'São escravos'. Não são companheiros de servidão, se pensares que todos estamos sujeitos aos mesmos golpes da fortuna.»" Está dado o mote para um rasgado elogio que Séneca tece a seu amigo Lucílio, destinatário da carta, ${ }^{2,5}$ por este lidar os seus escravos como se de familiares se tratasse.

O comportamento de Lucílio para com os escravos ainda se torna mais louvável a partir do momento em que Séneca o confronta com a crueldade com que muitos senhores da sua época tratavam os seus servos. ${ }^{26}$ Assim, por pura vaidade, muitas pessoas das classes sociais superiores recusavam-se a comer com o seu pessoal doméstico: uma multidão de escravos, de pé, assistia

${ }^{21}$ L. D. Riynolds, L. Amnaei Senecae ad Lucilium epistulae morales, Oxford, University Press, 1965. Trad. de J. A. Skgurado E Campos, Lúcio Aneu Séneca, Cartas a Lucílio, Lisboa, Fundação Calouste Gulbenkian, 1991.

${ }^{25}$ Há quem defenda que as Ad Lucilium epistulae morales não passam de ficções literárias.

26 Caso paradigmático é o de Védio Polião, que, de acordo com Cl.1.18.2ss. e Dial. 5.3.4.0.2-3, lançava os seus escravos às moreias por motivos tão banais quanto a quebra de um copo de cristal. 
ao espectáculo degradante de ver o senhor empanturrar-se e, por vezes, vomitar o que tinha comido (47.2). O chicote castigava o autor do mínimo ruído, mesmo quando esse ruído correspondia a um espirro ou um soluço. Os escravos passavam longas horas de pé, sem comer e sem falar (47.3); tinham de levar a cabo tarefas degradantes, como limpar os escarros; ou, de gatas, apanhar o vomitado dos convivas (47.5); ou ainda de servir, vestidos, pintados e depilados como mulheres, o vinho, e, depois, satisfazer a lascívia dos senhores (minister; 47.7); ou ainda outros serviços que certamente não lhes dariam qualquer satisfação, como trinchar as aves (47.6), inspeccionar o grau de voracidade ou a capacidade de adulação dos convivas (47.8), ou conhecer o paladar do senhor e criar novos pratos que despertassem a sua gula (47.8). Razão tinha pois Séneca quando afirmava que os escravos eram tratados ne tamquam hominibus quidem sed tamquam iumentis. (47.5: «... como se eles não fossem homens, mas bestas de carga.»).

Além de considerar a escravatura um indiferente, recorre Séneca aos conceitos de beneficium e ministerium para diluir a distinção entre homens livres e escravos. Partindo do pressuposto de que o ministerium implica a obrigatoriedade de fazer algo pelos outros (3.18.1) e o beneficium, a realização altruísta e voluntariosa de acções em favor de outrem; de que a relação entre escravo e senhor é da mesma natureza da que existe entre súbdito e rei, ${ }^{27}$ e soldado e general (Ben. 3.18.3); de exemplos de escravos cujo comportamento para com seus senhores excedeu largamente o domínio do ministerium (Ben. 3.23.1-27.4); considera o filósofo, em Ben. 3.18-28, que um escravo, por poder realizar beneficia para o seu senhor, ${ }^{28}$ adquire a liberdade que está ao alcance de qualquer homem, independentemente da sua condição (Ben. 3.21 .2 e 3.22 .3$)^{2.9}$

"2 Por isso procura Séneca, em Cl. 1.18.2ss. e 1.26.1, mostrar a Nero que não deve tratar os seus súbditos com a elevada crueldade com que alguns senhores tratam seus escravos: tal atitude apenas the trará o ódio de seus súbditos e o desejo do assassinarem. O paralelo entre o tratamento dos escravos e o modo como se deve conduzir um estado também ocorre em Dial. 5.3.35.1. Os homens indomáveis, que não podem ser escravos e, portanto, governados, também nào sabem, de acordo com Dial. 4.2.15.4, governar.

${ }^{2 *}$ De acordo com Cícero, Off. 3.89, esta questão já tinha sido equacionada por Hecatão.

* Em Ep. 31.11, sustenta Séneca que uma alma justa tanto se pode encontrar num cavaleiro romano, como num liberto, como num escravo. Ao referir, porém, a ignorância entre as causas da cólera, observa o filósofo, em Dial. 4.2.31.4, que o senhor deve esperar que o escravo trabalhe mal, para não ser surpreendido e ficar irado. 
A preocupação de Séneca com os escravos, que os passos citados parecem sugerir, foi encarada com desconfiança pelos contemporâneos do filósofo, que o acusavam de incoerência, na medida em que continuava a ter servos: veja-se, por exemplo, a paródia que de $E p$. 47.1 faz Petrónio, no seu Satyricon, mais precisamente em 71.1, onde coloca na boca de um rico e inconstante liberto, Trimalquião, afirmações do mesmo teor ${ }^{30}$; bem como por autores modernos que nelas não encontraram quaisquer novidades em relação às práticas e sugestões de Catão, Varrão e Columela;" mas viram, por um lado, uma preocupação egoísta do filósofo de não ceder ao affectus da cólera no tratamento dos escravos, ${ }^{32}$ e, por outro, uma forma de descomprimir as tensões sociais do sistema, e assim contribuir para a sua manutenção. Quanto às ideias de Séneca expostas em Benl. 3.18-28, objecta Bradley que são de natureza diversa as relações entre servos e senhores, entre subordinados e reis e entre soldados e generais. Por outro lado, o filósofo exagera no poder do escravo de se recusar a obedecer a um senhor, bem como na sua relutância em prejudicar o estado ou em agir com mau propósito."

Em Dial. 7.17.1-2, Séneca parece revelar consciência das críticas de que era alvo: é, pelo menos, o que se depreende da incongruência entre algumas

${ }^{30}$ et serui homines sunt et aeque unum lactem biberunt, etiam si illos malus fatus oppresserit. "Também os escravos são seres humanos e beberam do mesmo leite, ainda que um destino funesto os traga oprimidos.» Conjugado com os demais em que o senhor interage com os seus servos, o passo citado acaba por ser sugestivo da limitada humanitas de Trimalquião, e constitui ainda um retrato ímpar do modo como muitos libertos tratavam os seus antigos companheiros de servidão.

${ }^{31}$ Plutarco, Cat. Ma. 1.9, 3.2, 20.5ss.; Varrão, R. 1.17 e 2.10 e Columela 1.7-8. Homero, cm Od. 17.322-3, afirmou que a escravidão limita a arete conferida por Zeus.

${ }^{32} \mathrm{Em}$ Dial. 4.2.25.3, diz o filósofo que, quando os prazeres corrompem o espírito, nada se tolera, e o facto de um escravo deixar cair uma chave é pretexto para severo castigo. A propósito da cólera que deixa fugir ou mata escravos, observa Séneca: Quanto plus irascendo quam id erat propter quod irascebatur amisit! (L. D. Reynolds, L. Annaei Senecae dialogorum libri duodecim, Oxford, University Press, 1977.) (Dial. 5.3.5.4: "Quanto mais perdeu, ao encolerizar-se, do que aquele pelo qual se encolerizava!»)

${ }^{31}$ Bradley (1986) passim. A preocupação de Séneca com os escravos pode, nesta linha, ter motivações semelhantes às de Gaio Cássio Longino, pois, em Ben. 3.13.1, já Séneca revelara consciência das tensões geradas por uma sociedade estratificada e da insegurança que os ajuntamentos de escravos provocavam nas classes dirigentes. Essa insegurança é bem visível no sentimento que esteve na base da rejeição da hipótese, considerada pelo senado, de obrigar os escravos a usarem roupa diferente (Clem. 1.24.1), tal era a superioridade do seu número em relação ao das pessoas livres ( $E p .4 .7 .5)$.

"Bradley (1986) 163. 
das ideias do passo referido e as de outros ${ }^{25}$, bem como das semelhanças entre algumas destas informações e as que, sobre a fortuna de Trimalquião, Petrónio nos faculta no seu Satyricon. ${ }^{36}$ Para o nosso propósito, importa, contudo, ter em conta as alusões senequianas aos servos do visado pelos adversários da filosofia: seus jovens escravos trajam roupas valiosas; o narrador, ou por descuido, ou pelo elevado número de seus serviçais, não os conhece. Às diversas críticas responde, por fim, o filósofo que não é sábio, nem o será. Por isso, devem exigir-lhe, não que seja igual aos melhores, mas melhor do que os piores. Basta-lhe melhorar um pouco todos os dias (Dial. 7.17.3). ${ }^{37}$

Entre os modernos investigadores que tentaram reabilitar a imagem de Séneca, conta-se Sorensen, que sustenta a possibilidade da $E$ p. 47 ter sido uma resposta ao famoso discurso de Gaio Cássio Longino no Senado, que, a propósito do assassínio de Pedânio Segundo por um dos seus escravos, em 61, e em estrita obediência à lei romana, defendera a necessidade de dominar os escravos pelo medo e de, consequentemente, executar os restantes servos do falecido, incluindo velhos, mulheres e crianças (Tácito, Ann!. 14.42-44). ${ }^{38}$ Além de não deixar de manifestar a sua estranheza relativamente ao silêncio

${ }^{35}$ A pergunta que os críticos da filosofia dirigem ao narrador, no sentido de saberem porque é que este proporciona às orelhas de sua esposa as riquezas duma família abastada (Dial. 7.17.2), talvez se justifique pela contradição com Dial. 2.14.1, onde Séneca critica a loucura dos que cuidam que podem ser ofendidos por uma mulher, se não seguirem o protocolo dos cumprimentos: é que a carga das orelhas do ente feminino, entre outras coisas, não tem qualquer importância. Quanto à pergunta sobre as posses no outro lado do mar (Dial. 7.17.2), Séneca menciona, de passagem, em Ep. 77.3, as suas propriedades no Egipto (sobre o papiro de 62 d.C. que confirma esta informação, v. comentário a 7.17.2 de C. CODOÑir, Lucio Anneo Séneca, Diálogos, Madrid, Tecnos, "1999, 246 n. 39).

${ }^{*}$ Como os críticos da filosofia perguntam ao narrador porque chora a morte da mulher e de um amigo (Dial. 7.17.1), também Trimalquião desata a carpir enquanto indica o epitáfio que deseja ver no seu túmulo (Petr. 72.1); como o alvo dos críticos da filosofia tem um especialista para trinchar as peças, assim Trimalquião tem o seu Carpus (Petr. 36.8); como o narrador não conhece os seus escravos, o mesmo sucede com Trimalquião (Petr. 37.9).

${ }^{37}$ Em Dial. 7.24.3, diz Séneca que.concede beneficia por igual a escravos e homens livres, por nascimento ou manumitidos.

${ }^{3 *}$ O Senado acabou por decretar a morte dos quatrocentos escravos de Pedânio, mas o povo de Roma defendeu que as crianças deveriam ser poupadas ao castigo. Quando se preparava a execução, grandes multidões, armadas com pedras e tochas, impediram a execução. Nero, porém, fez retirar a população por edicto e rodeou a zona da execução com tropas, fazendo deste modo cumprir a pena. O caso é sugestivo das tensões sociais da Roma da época de Séneca. 
de Tácito quanto a um possível reacção de Séneca ao sucedido, o investigador dinamarquês vê na referência de Ben. 3.23.3, à lei que previa a existência de um magistrado - talvez um praefectus urbi, a quem os escravos se poderiam queixar dos desmandos dos senhores e a quem caberia pôr termo à crueldade, à luxúria e à avareza dos senhores para com os seus servos -, um indício de que o filósofo terá sido o autor do referido decreto.

Quanto aos argumentos apresentados por Bradley, convém dizer que, embora, no geral, pareçam pertinentes, existiriam situações em que o escravo poderia, de sua livre vontade, agir em favor do seu senhor. É certo que, embora defendesse que uma resposta mais arrojada de um escravo não deveria ser motivo para açoites e cadeias (Dial. 5.3.24.2), e que os açoites, a quebra das pernas do escravo (Dial. 5.3.32.1-2) e a pena de morte deveriam ser aplicados apenas em último recurso, Séneca não era, por princípio, contra estes tipos de punições. Além disso, nenhum autor assocịa Séneca à lei referida em De beneficïs. Não deixa, contudo, o filósofo de manifestar a sua admiração pela coragem com que alguns desses servos encaram a morte. Exemplo supremo dessa situação ocorre nas Troades, onde o Mensageiro realça a admiração dos vencedores gregos perante o modo determinado como Astíanax, símbolo derradeiro da esperança troiana numa reconstrução da cidade, se lançara, a meio do ritual e sem esperar que o seu carrasco o empurrasse da torre, para uma morte mais do que certa (1068 ss.).

Exigir a Séneca, um homem de estado, que viveu numa época de profunda instabilidade política e social, a apresentação de teorias abolicionistas da escravatura traduziria uma expectativa demasiado ambiciosa e que não teria em conta os condicionalismos históricos, políticos e económicos de uma sociedade de matriz esclavagista. Não é possível, no entanto, deixar de assinalar o grande avanço em relação a autores que já defendiam um tratamento mais humano dos escravos, como, entre outros, Cícero e Horácio. Apesar das obras destes autores ecoarem os preconceitos relativos aos escravos, ${ }^{\text {th }}$ a ver-

${ }^{3}$ "Homens corajosos" são, de acordo com Benl. 2.34.3, os gladiadores ou os escravos, que uma acção irreflectida levou a desprezar a morte; em Ep. 24.14, Séneca alude ao destemor com que um seu escravo e uma sua escrava enfrentam a morte.

"Cícero, na sua vivência pessoal, confirma a ideia generalizada que os romanos do seu tempo herdaram da mentalidade arcaica, segundo a qual os escravos tinham uma natural propensão para cometer más acções. Em Att. 7.2.8 alude ao caso de Crisipo, preceptor de seu filho, que roubara e fugira, apesar do bon acolhimento que Cícero lhe dera. Também Horácio recorre ao preconceito de que o escravo tem uma natural inclinação para o vício, quando 
dade é que o primeiro não deixa de demonstrar gratidão para com o seu pai, um antigo escravo $(S .1 .6)$; e o segundo uma profunda admiração por seu escravo e confidente Tirão, a quem reconhecia grandes capacidades intelectuais, e que, juntamente com Estácio, considerava exemplos de homens caídos na servidão por circunstâncias injustas (Fam. 13.21, 23, 26, 33, 38, 45, 46, $69,70)$.

Talvez valha a pena abrir aqui parênteses para uma breve referência à importância dos escravos gregos cultos na "helenização" de Roma: Lívio Andronico, um escravo grego, traduziu a Odyssea e tragédias e comédias gregas para Latim. Políbio, um dos reféns de Pidna de 168 a.C., era um notável historiador e tomou conta da educação de Cipião Emiliano. Epicteto, nascido em Hierápolis, na Frígia, escravo de um secretário de Nero, tornou-se um dos pensadores mais importantes, a par de Séneca e Marco Aurélio, da filosofia estóica.

Esta seria seguramente a situação de Sosítio, cuja morte, como o próprio Cícero confessa em Att. 12.4, o comovera mais do que devia. É ainda pelo testemunho de Cícero que encontramos um dos relatos mais comoventes e reveladores da dignidade dos escravos. Em Clu. 62.175-63.177 e 65.18266.187, Sássia manda torturar três escravos para lhes arrancar uma falsa confissão. A resistência dos servos perante suplícios cada vez maiores leva a que os convidados se acabem por compadecer deles e solicitem a interrupção da sessão. Após o relato desta história, não se coíbe, porém, Cícero de narrar o sucedido a um desses escravos: posteriormente roubou e assassinou. Além disso, se Cícero, em Off.13.41, recomenda que se trate o escravo de forma justa, isto é, que se lhe exija trabalho, mas se lhe forneça o que é devido, Horácio, em $S .1 .3 .80$, observa que a simples crucifixão de um escravo por este ter 'devorado restos de peixe' ou 'bebido um molho já morno' suscitaria uma condenação por parte de pessoas sensatas; e o mesmo aconteceria em relação a quem apedrejasse em público escravos comprados a suas expensas 118 Ep. 2.2.133.

No entanto, como refere W. Den Boer," a humanitas de Cícero, e pensamos que também de Horácio, não assenta na natureza biológica ou espiritual, nem na igualdade de direitos entre todo o ser humano. O termo diz

demonstra que um escravo nào rouba por ter amor à virtude, mas pelo receio de ser punido (Ep.1.16.46-56).

"Boer (1979) 89-92. 
antes respeito ao lugar que o indivíduo ocupa num modelo social ainda bastante semelhante ao da estrutura familiar arcaica.

Embora esta constatação possa aplicar-se, no que à sua dimensão da prática social diz respeito, a Séneca, a novidade do seu pensamento consiste em enquadrar o problema da escravatura no âmbito de uma reflexão fillosófica mais alargada sobre a condição humana. É, pois, no quadro desta reflexão, que o escravo ganha uma humanidade comum àquela que está ao alcance dos restantes homens livres. Neste sentido, embora o escravo não atinja, no pensamento de Séneca, liberdade efectiva, vê-se dotado de uma capacidade de optar entre o bem e o mal que o torna parte integrante do género humano.

$\mathrm{O}$ desfasamento entre os manifestos de intenções e a realidade é algo que não ocorre apenas num dado momento da história, e no confronto entre a vida e a obra de um determinado autor, mas, numa ampla variação diacrónica, ao longo do período temporal em análise. Apesar dos reiterados conselhos dos autores de tratados sobre agricultura, no sentido de os senhores darem um tratamento melhor aos seus servos rurais, encontramos, no séc. II d.C., um dos relatos mais horrendos das condições infra-humanas em que se encontravam aqueles indivíduos. É o romancista Apuleio quem, em Asinus aureus 9.12, escreve:

'Dii boni, quales illic homunculi uibicibus liuidis totam cutem depicti dorsumque plagosum scissili centunculo magis inumbrati quam obtecti (...) frontes litterati et capillum semirasi et pedes anulati, tum lurore deformes et fumosis tenebris uaporosae caliginis palpebras adesi atque adeo male luminati, et in modum pugilum qui puluisculo perspersi dimicant farinulenta cinere sordide candidati *2 $^{*}$

"'Deuses de bondade, que caricaturas de homens ali estavam, com a pele toda zebrada de vergões lívidos e o lombo em chaga, antes sombreados que cobertos por farrapos remendados! (....) traziam as testas marcadas com letras e o cabelo rapado por metade e os pés metidos em argolas. Além disso, estavam desfigurados por uma lividez cadavérica e com as pálpebras roídas pelas trevas enfumaradas da caligem ardente e, por isso, quase cegos, e, de forma semelhante aos pugilistas que comba-

"Apulée, Les Métamorphoses, tome III, texte établi par D. S. Robertson et traduit par Paul Vallette, Paris, Les Belles Lettres, 1985, 73. 
tem cobertos de pó, eles estavam sordidamente esbranquiçados por uma cinza farinhenta.'»

De todas as abordagens literárias da escravatura em autores latinos, é talvez em Marcial que se encontra uma preocupação mais sincera com a situação real do escravo. Sem qualquer enquadramento de natureza filosófica e num género considerado menor, o epigrama, mas cuja espontaneidade é um bom indício da sinceridade do poeta, encontramos o amargurado e revoltado desabafo seguinte (10.31):

Addixti seruum nummis here mille ducentis, ut bene cenares, Calliodore, semel.

Nec bene cenasti: mullus tibi quattuor emptus

librarum cenae pompa caputque fuit.

Exclamare libet: "Non est hic, improbe, non est

piscis: homo est; hominem, Calliodore, comes».

«Vendeste ontem um escravo por mil e duzentos sestércios

para jantares bem, Caliodoro, uma única vez.

Mas bem não jantaste tu: o ruivo de quatro libras que

compraras foi a pompa e o prato principal do teu jantar.

Apetece gritar: «Isto não é um peixe, não,

meu desgraçado, é um homem: é um homem, Caliodoro, que tu comes.m»" ${ }^{13}$

Estas palavras indiciam claramente uma sensibilidade que traduz uma humanitas que anula a importância da condição social e valoriza apenas a condição humana do indivíduo."

Embora o direito traduza, em suma, a dura realidade a que os escravos romanos eram submetidos, a verdade é que a literatura técnica, preocupada com a estabilidade e o bom rendimento da uilla, e a literatura política e filosófica, interessada no melhor tipo de relação que Roma devia ter com os

${ }^{3}$ Texto latino é de Martialis epigrammata edidit D. R. Shackleton Bailey. Stutgardiae in aedibus B. G. Teubneri, 1990; a tradução, de Paulo Sérgio Ferreira in Cristina de Sousa Pimentel et al., Marcial. Epigramas, vol. IV, Lisboa, Ediçōes 70, 2004, 36.

"Este assunto é tratado mais de espaço em Brandão (1998) 119-24. 
povos conquistados ou, noutra época, na estabilidade social, já propunham tratamentos mais humanos dos escravos. No extremo oposto - o do sonho, o da inversão temporária da ordem social, o dos doces prazeres da vida galante - o escravo passava, num ápice, de condenado a senhor e vice-versa. Em todo o caso, o tema foi tão importante na sociedade romana, que forneceu ampla imagética para a reflexão de natureza amorosa, literária e moral. Em nenhum dos quadros anteriores se encaixa o pensamento de Marcial, pois o mal-estar que neste poeta se pressente em relação ao modo como os escravos eram tratados no seu tempo está muito próximo do sentir actual em relação à escravatura.

No entanto, e apesar de não ter subjacente o peso político da denúncia, não é possível deixar de reconhecer - e este constitui certamente um dos maiores contributos da literatura latina para o tratamento do problema da escravatura - que a criação destas personagens e dos seus mundos acabou por, à semelhança do que sucedeu com a exposição dos dramas de Cosette, Valjean e Gabroche em Les Misérables (1862) de Victor Hugo, dar visibilidade a uma esfera do tecido social que, pelas circunstâncias dominantes, se configuraria como uma esfera sem expressão.

E ainda no tocante à realidade, embora a escravatura tenha perdurado durante séculos como um dos indicadores de maior opressão social, ${ }^{15}$ não é possível deixar de evidenciar que, contrariamente à ideia de que a prática generalizada da escravatura assentou sempre na visão de que os povos conquistadores se contemplavam como civilizadores dos povos que escravizavam, em Roma, além de se terem criado condições peculiares que possibilitaram a manumissão, assiste-se (embora apenas no tocante a uma minoria - a dos escravos gregos cultos) a um movimento de adesão aos valores e à cultura do escravo, considerado enquanto elemento portador de uma civilização. ${ }^{16}$ Este

${ }^{15}$ Molina, Luis de, Mancipia, disp. 32, observa: «Estes homens, como se lê na Instituta de iure personarum, parágrafo Serui, são chamados servos, cuja origem é seruando, visto que os imperadores conservavam os que capturavam na guerra e que licitamente poderiam matar, comutando a sua morte com a servidão perpétua. (....) Disto resulta que esta servidão foi introduzida para bem dos próprios escravos, uma vez que a escravidào perpétua é, para eles, um mal menor em comparação com a privação da vida. (....) É bastante evidente que esta scrvidão é lícita e justa (....).»

${ }^{16}$ Vejam-se as considerações de Horácio, Ep. 2.1.156-7: Graecia capta ferum uictorem cepit et artes intulit agresti Latio... ("A Grécia vencida conquistou o seu feroz vencedor e no Lácio agreste as artes introduziu ...» (Trad. de Rocha-Piriara (2000) 204); e Virgíl.Io, En. VI. 847-850: Excudent alii spirantia mollius aera, credo equidem, uiuos ducent de marmore 
reconhecimento deixa já evidenciar o elevado cosmopolitismo da Urbe. Na medida em que concebe dentro das suas fronteiras um movimento que, ao invés de aniquilar simplesmente, aceita o outro, reconhece o interesse e até a superioridade de alguns dos seus valores e acaba por integrá-los na sua própria cultura, assimilando-os por vezes, o referido cosmopolitismo assume-se como uma das principais conquistas reivindicadas pela moderna Europa.

\section{Bibliografia}

G. AlföldDy, A história social de Roma. Trad. M. Cary (Lisboa, Presença, 1989).

W. den Bokr, Private morality in Greece and Rome: some historical aspects (Leiden, Brill, 1979)

K. R.Bradlly, "Seneca and slavery", 37 (1986) 161-72.

José Luís Lopes Brandĩo, Da quod amem. Amor e amargor na poesia de Marcial (Coimbra, Colibri, 1998).

Paulo Sérgio FErreira, “A escravatura na Antiguidade”, BEC28 (1997) 71-80.

—_. "A escravatura em Roma: o testemunho da comédia”, BEC29 (1998) 61-68.

, "Cícero e a escravatura”, BEC31 (1999) 95-107.

—., "A escravatura na obra de Horácio", BEC 34. (2000) 115-119.

——, “O vocabulário da escravatura em Ovídio", BEC 35 (2001) 71-79.

Walter de Misiriros, “A apoteose do escravo na cena final do Epídico de Plauto”, Biblos 57 (1981) 379-394.

Maria Helena da Rocha-Perlina, Romana. Antologia da cultura latima. (Universidade de Coimbra, '2000)

Maria Helena da Rocha-Prereira, Estudos de história da cultura clássica. I vol. - Cultura grega (Lisboa, Fundação Calouste Gulbenkian, ${ }^{9} 2003$ )

122 António Santos Justo, "A situação jurídica dos escravos em Roma”. Boletim da Faculdade de Direito 59 (1983) 128-80.

Villi Sorensen, Seneca, trad. a cura di Bruno Berni (Roma, Salerno Ed., 1988).

uoltus, orabunt causas melius, caelique meatus/ describent radio et surgentia sidera dicent; ${ }^{16}$ («Outros modelarão, bem o creio, bronzes com vida / e sem dureza; extrairão do mármore seres animados; / defenderão melhor as causas; medirão com o compasso / o curso dos céus e anunciarão o nascer dos astros» (Trad. de Rocha-Pereira (2000) 164). 


\title{
APPUNTI SULLE VARIABILI E COSTANTI DELL' INTERPRETATIO RELIGIOSA NELL'OCCIDENTE ROMANO
}

\author{
Giulia Baratta \\ (Università di Macerata)
}

Vista da fuori con gli occhi di chi non la conosce, l'Europa di oggi può apparire come una entità relativamente uniforme; vissuta e conosciuta da dentro l'Europa si rivela invece per quella che è: un insieme di numerosissime realtà territorialmente anche molto limitate, diverse per storia, cultura, lingua, economia e dunque per volontà ed aspettative. Alla base dell'Europa è certo una storia comune ma tanto ricca, complessa e sfaccettata da non poter generare altro che questo caleidoscopio di piccoli-grandi mondi.

Queste divèrse realtà territoriali pur conservando le loro peculiarità non sono però delle entità chiuse. Ricco e intenso è sempre stato lo scambio di uomini, idee e merci che ha favorito l'interscambio culturale.

Un buon esempio di questo fenomeno in epoca romana è l'ambito religioso.

Lo studio della realtà cultuale antica delle province europee dell'impero romano non può prescindere da una analisi della cosiddetta interpretatio Romana. Questo termine corrisponde ad una categoria logica moderna che la storiografia ha applicato allo studio della religione di ambito provinciale, e che è desunto da un passo della Germania di Tacito in cui lo storico scrive $(43,3)$ :

Apud Nahanarvalos antiquae religionis lucus ostenditur. Praesidet sacerdos muliebri ornatu, sed deos interpretatione Romana Castorem Pollucemque memorant. Ea vis numini, nomen Alcis. Nulla simulacra, 
nullum peregrinae superstitionis vestigium; ut fratres tamen, ut iuvenes venerantur.

Presso i Naharvali è indicato un bosco sacro per antica devozione. Vi celebra il rito un sacerdote in abbigliamento muliebere, ma gli dei venerati si dice che siano, secondo l'interpretazione romana, Castore e Polluce. Tale il carattere della divinità, ma il loro nome Alci. Nessuna immagine, nessuna traccia di religiosità straniera; tuttavia sono venerati come fratelli, e come giovani'.

Questa interpretatio è dunque un procedimento in base al quale una determinata cosa o concetto non viene tanto traslitterato ma piuttosto rinominato con un termine proprio di una lingua diversa da quella latina che ne riproduce perfettamente significato e contenuto; in sintesi si tratta di una traduzione sulla scorta di quanto scritto nella Rethorica ad Herennium $(4,28,33)$ : Interpretatio est quae non iterans idem redintegrat verbum, sed it commutat, quod positum est, alio verbo, quod idem valeat 'L'interpretatio è quella che pur ripetendola non ripete la stessa parola, ma cambia quella che c'è con una altra dello stesso valore'; e da Girolamo nelle sue Epistulae $(57,5,2)$ : in interpretatione Graecorum...non verbum e verbo, sed sensum exprimere de sensu 'Nell' interpretatio dei Geci... non (si deve tradurre) parola per parola ma esprimere il senso del contenuto'. Ogni traduzione, però, per quanto voglia essere corretta e soprattutto oggettiva, non è esente dall'interpretazione di chi la fa come traspare anche da un passo delle Institutiones di Quintiliano $(10,5,5)$ : neque ego paraphrasin esse interpretationem tantum volo, sed circa eosdem sensus certamen atque aemulationem 'Io non voglio che l'interpretatio sia solo uno parafrasi, ma una sfida e una gara circa gli stessi contenuti'. L'interpretatio, dunque, riflette bene anche tutti gli altri valori insiti nella parola come quelli di interpretazione, giudizio, congettura ecc....2.

Il summenzionato passo di Tacito (Germania 43,3) non è, però, di

124. facile comprensione perchè lascia adito ad una duplice lettura. Lo storico scrive infatti "deos interpretatione Romana Castorem Pollucemque memorant": dal passo infatti non risulta chiaro se si tratta di una sua "traduzione" dei nomi di divinità adorate dai Germani o se, al contrario, sono i Germani stessi gli artefici dell'interpretatio poi riproposta dallo storico nel testo scritto.

\footnotetext{
' Traduzione di Luca Canali tratta da Tacito, La Germania, Roma 1983, p.113.

${ }^{2}$ Cfr. s.v. interpretatio, in ThLL VII,1, coll. 2253-2257.
} 
Appare comunque assai probabile la prima ipotesi, ovvero che Tacito, per facilitare la comprensione della narrazione al lettore non informato sulla realtà della Germania applichi a questa categorie logiche proprie di Roma al fine di poterla rendere più intellegibile come, del resto, fa anche Cesare nel De bello Gallico $(6,17)$ :

Deorum maxime Mercurium colunt. Huius sunt plurima simulacra, hunc omnium inventorem artium ferunt, hunc viarum atque itinerum ducem, hunc ad quaestus pecuniae mercaturasque habere vim maximam arbitrantur. Post hunc Apollinem et Martem et Iovem et Minervam. De his eandem fere quam reliquae gentes habent opinionem: Apollinem morbos depellere, Minervam operum atque artificiorum initia tradere, Iovem imperium caelestium tenere, Martem bella regere...

II più venerato degli dei è Mercurio, di cui esistono molte immagini. Lo ritengono l'inventore di tutte le arti, il protettore delle strade e dei viaggi, credono che più di ogni altro abbia il potere di far guadagnare danaro e di favorire il commercio. Venerano dopo di lui Apollo, Marte, Giove e Minerva, del cui potere hanno idee simili a quelle degli altri popoli: Apollo guarisce dalle malattie, Minerva insegna i principi dei lavori manuali, Giove è il signore del cielo, Marte presiede alle guerre".

Il concetto moderno di interpretatio va al di là di quanto fanno Tacito e Cesare perchè con esso non si fa riferimento solo alla mera traduzione del nome di divinità ma si vuole indicare tutto il processo di formazione di un nuovo mondo cultuale nato dal contatto tra Roma e le popolazioni autoctone che, come scrive F. Marco riguardo all'Europa continentale", dobbiamo definire romano-celtico poiché ha caratteristiche differenti dagli orizzonti indigeni preesistenti all'arrivo dei Romani e da quelli propri della religione dell'Urbe. Si tratta comunque di un fenomeno ben noto alla cultura romana il cui pan-

"Traduzione di Maria Pia Vigoriti tratta da Gaio Giulio Cesare, La guerra gallica. La guerra civile, Roma, 1995, p.219.

' F. MARCO, "Integración, interpretatio y resistencia religiosa en el occidente dell'Imperio", in La romanización en occidente (J.M. BLÁzQulz, J. Alvar edd.), Madrid 1966, p.218. 
theon è già figlio di una interpretatio con quello dei Greci, degli Etruschi e delle popolazioni italiche.

Va detto che un'interpretatio, pur intesa come costituzione di una nuova realtà religiosa, che parte, però, dallo stesso punto di vista di Tacito e di Cesare, e che si configura dunque come Romana, costituisce un processo unidirezionale che va dal mondo romano a quello indigeno senza tenere conto degli apporti di quest'ultimo. Per ovviare al problema la critica storica ha introdotto la categoria di interpretatio Gallica. J.J. Hatt riassume brillantemente la complessa questione nella sua fondamentale opera dedicata agli aspetti religiosi della Gallia : "L'interprétation romaine consiste à traduire en mots ou en images gréco-romaines, à l'usage des fidèles romains, ou romanisés, lés conceptions religieuses celtiques. L'interprétation celtique consiste, au contraire, dans l'utilization par les Celtes, pour leur propre usage, d'images et même de concepts ou de termes gréco-romains pour exprimer leurs propres idées religieuses".

Ripercorrere, il processo dell'interpretatio non è compito facile poiché si tratta di un fenomeno molto complesso come dimostrano i numerosi aspetti in cui esso si rivela che vanno ben al di là della sola realtà cultuale.

Tra i più evidenti è certo l'adozione di specifiche forme monumentali nei territori entrati in contatto con Roma, quali sono gli altari, le stele ecc..., mutuate dalla cultura romana, in cui continuano a permanere, però, elementi del substrato indigeno che si rivelano in particolare nell'ornato e nello stile del corredo iconografico come mostra, e lo cito a solo titolo di esempio tra migliaia, una stele di Manzaneda de Cabrera.

'J.-J. HATT, Mythes et dieux de la Gaule, Paris 1989, p.9. Sul fenomeno dell'interpretatio vedi tra l'altro M. HiNIG, "Ita intellexit mumine inductus tuo: some personal Interpretations of Deity in roman Religion”, in M. Henig, A. KING Pagan Gods and Shrines of the Roman Empire, Oxford 1986, pp. 159-169 ; J. D'ENCARNAÇÃo, "O conceito de divinidade indígena sob o domínio romano da Península Ibérica”, in Actas do II Congreso Nacional de Arqueologia (Coimbra 1970), Coimbra 1971, II, p.347-349; P. LÉVÊque, "Essai de typologie des syncrétismes", in Les syncrétismes dans les religions grecque et romaine. Colloque de Strasbourg 1.971, Paris 1973, p.179-185; J.M. BLÁzQtiz, "Los cultos sincréticos y su propagación por las ciudades hispanorromanas", in Los orígenes de la ciudad en el noroeste hispánico. Actas del Congreso Intemacional Lugo 1996, Lugo 1998, I, p.249-274. .

"F. Dilgo Santos, Inscripciones romanas de la provincia de León, León 1986, tav. CLXXVII. 
Più significativo ancora è l'introduzione dell'alfabeto e della lingua latina per le iscrizioni votive. I testi rivelano la presenza di divinità con nomi classici ed indigeni o con una combinazione di entrambi e l'adozione di formulari propri del mondo romano. L'onomastica delle divinità rivela $i$ contatti tra $\mathrm{i}$ diversi gruppi di popolazioni indigene e i Romani e le componenti autoctone e romane nella formazione della divinità "interpretata". Ne costituisce un esempio il caso del culto di Mercurio nella Penisola Iberica (fig.1). Qui infatti gli epiteti che designano il dio nelle zone più prossime ai Pirenei e, pertanto, alla Gallia, trovano riscontro anche in quest'ultima provincia, denotando un evidente contatto tra questi territori oltre che una ben specifica natura del dio, venerato come protettore delle strade e degli incroci, che non sembra ricorrere in altre zone della penisola e si rivela, dunque, caratteristica per la parte orientale. Il forte influsso degli elementi indigeni nel culto di Mercurio è invece più evidente nel Nord e Nordovest dove il nome del dio è associato ad epiteti che riprendono chiaramente i nomi di divinità locali alle quali Mercurio è stato associato per somiglianza di caratteri e funzioni. Allo stesso modo il maggióre grado di romanizzazione della parte mediterranea della penisola traspare nel culto di Mercurio che qui è venerato esclusivamente come divinità augusta'.

Tuttavia non è facile andare oltre queste constatazioni e ricostruire con precisione la natura stessa degli dei sulla base dei dati a disposizione. Non sappiamo infatti quanto un nome romano possa corrispondere ad una divinità classica e quanto invece non nasconda la presenza di divinità locali e la commistione con esse, così come non è chiaro se e quanto un nome indigeno indichi una divinità autoctona "originale" o quanto questa e il suo culto non siano già permeati di elementi estranei. Nel caso delle divinità auguste, inoltre, che non sono solo quelle per così dire urbane, ma nell'ambito delle quali si contano numerose divinità di origine indigena, c'è una traccia evidente di romanizzazione o, per meglio dire, una volontà di integrazione nel nuovo sistema sociale e politico. Le divinità indigene, dunque, non sono emarginate e possono anche essere oggetto di un culto pubblico se voluto dai magistrati

' G. BaratTa, Il culto di Mercurio nella Penisola Iberica, Barcelona 2001, in particolare p.107 ss. Per un quadro generale sulla Penisola Iberica in relazione e numerose altre divinità vd. A.M. VAzQulz Hoys, La religion romana en Hispania. Fuentes epigrálicas, arqueológicas y mumismáticas, Tesis doctoral, Madrid 1982. 
locali e dai decurioni ${ }^{8}$ e, come dice F. Marco ${ }^{9}$, considerate romane in senso istituzionale.

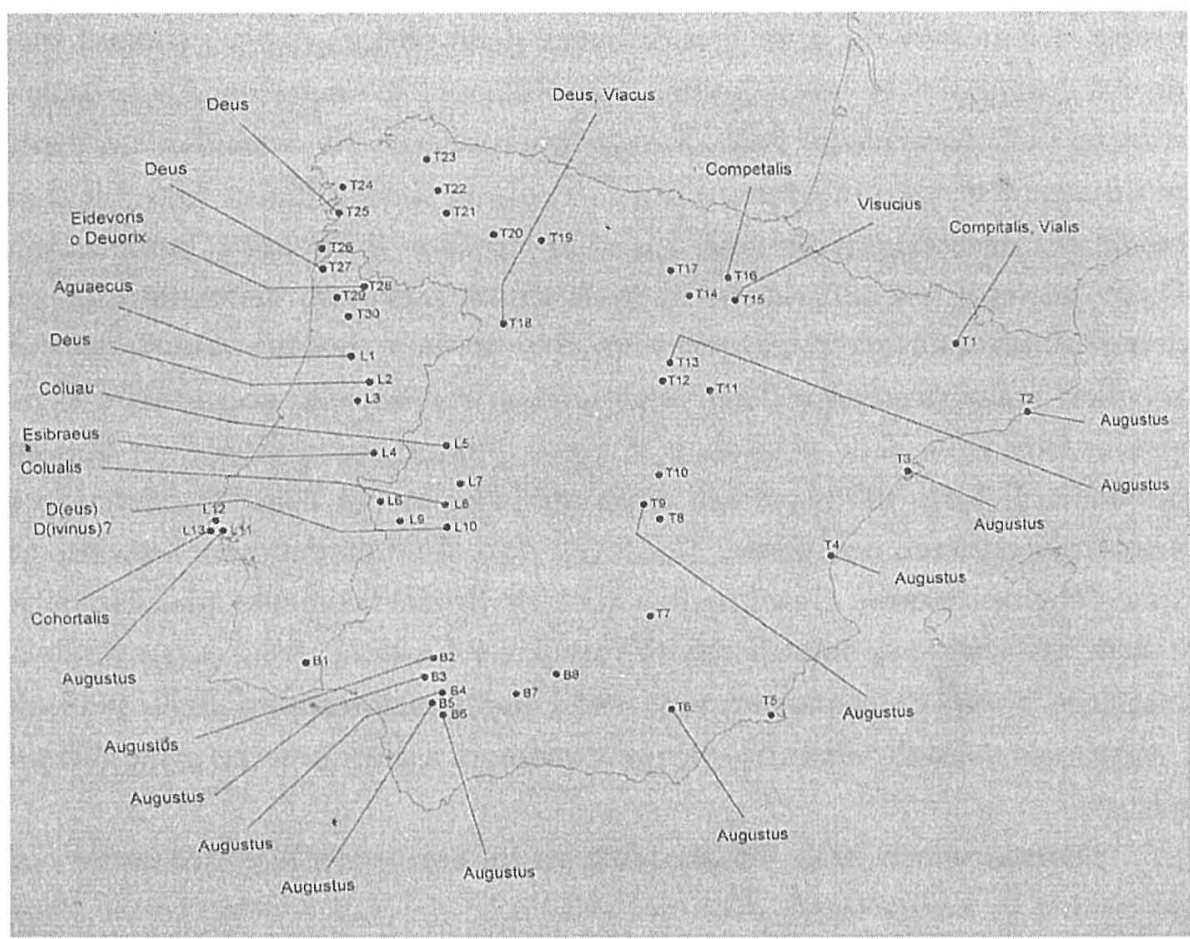

Fig. 1 - Distribuzione dei diversi epiteti di Mercurio nella Penisola Iberica sulla base delle testimonianze epigrafiche

L'onomastica dei dedicanti che è indice del loro maggiore o minore grado di romanizzazione, oltre che della loro origine e condizione sociale, rivela la misura in cui il pantheon romano-celtico è stato recepito dalle diverse componenti sociali e come l'appartenenza ad un determinato gruppo di ori128 gine può influire sulla scelta delle divinità e dei culti ad essa connessi. Mette comunque in evidenza una generale accettazione del nuovo pantheon da parte di tutta la società, vale a dire che soggetti di evidente origine indigena sono

"Vedi ad esempio J. Schlin), "Les religions", in F. Jacques, J. Scheid, Ronse et l'intégration de l'enpire, I. Les structures de l'Empire romain, Paris 1990, p.124-125.

"Marco, "Integración...", cit., p.219. 
legati a culti importati da Roma ${ }^{10}$ così come i Romani, o personaggi di un ambito fortemente romanizzato, non disdegnano culti chiaramente legati al mondo indigeno".

Il formulario epigrafico presente nelle iscrizioni votive è anche esso frutto della romanizzazione. Quello che non possiamo giudicare per le scarse informazioni che abbiamo sulla realtà autoctona è se, ed eventualmente in quale misura, esso non nasconda analoghe concezioni e un modo di sentire ed esprimere la natura delle divinità ed il rapporto dei fedeli con esse già presenti nel mondo indigeno ed ora tradotte, "interpretate" per dirla con Tacito, in latino. In particolare si tratta dell'uso di deus e dea che non di rado viene visto come paradigma del livello di romanizzazione e del grado più o meno avanzato nel processo di interpretatio ovvero assimilazione e sovrapposizione tra le divinità romane e quelle indigene. R. Etienne ${ }^{13}$ spiega il meccanismo con un procedimento forse troppo legato ad una logica cartesiana e sostiene, facendo l'esempio di Mars e Cosus, una evoluzione a tappe a partire da Cosus,

${ }^{10}$ Cfr. a solo titolo di esempio gli interessanti casi in M. ŠAŠlL KOS, The Roman Inscriptions in the National Museum of Slovenia: Lapidauij Narodnega muzeja Slovenüje, Ljubljana 1997, nn. 95 (Savis Augustus), 108 e 109 (Adsalluta Augusta).

"Ne è esempio un'iscrizione, recentemente rinvenuta in Franche-Compté, relativa alla dedica di una statua a Cicollus, una divinità venerata nel territorio dei Lingones e spesso associata a Marte, da parte di Caius Iulius Titullus Cai Iulii Titi filius sacerdos Augustorum, vd. G. BARIBE,T, R. BillikreY, "Une plaque de bronze avec dedicace découverte en FrancheComté", in Gallia 61, 2004, p.181-190.

${ }^{12}$ Sull'uso di deus e dea vedi M.-T. Rakpsalt-Charlilir, Diis deabusque sacrum. Formulaire votif et datation dans les trois Gaules et les deux Germanies (Gallia Romana I), Paris 1993; M.-T. RaipSAlT-Charliler, "A propos des premiers emplois datés de Deo-deae dans les trois Gaules et les Germnies", in ZPE 61, 1985, p.204-208 ; M.-T. RAlipsaltT-Charlilir, "La datation des inscriptions latines dans les provinces occidentales de l'Empire Romain d'aprés les formules "In H(onorem) d(omus) d(ivinae)" et "Deo, Deae", in ANRW I̦I, 3, Berlin, New-York 1975, p.232-282 ; S. LAMbrin(), "Les cultes indigènes en Espagne", in Les empereurs romains d'Espagne, Paris 1965, p.223-24.2 ; M.M. Llitnissin, "Römische Götternamen und einheimische Religion der Provinz Germania Superior", in FundBerBW 10, 1985, p.172; R. EtIlenne, "Les syncretismes religieux dans la Peninsule Iberique à l'époque imperiale", in Les sincretismes dans les religions grecques et romaines, Paris 1973, p.153-163; R. ETILnNe, G. Fabre, P. Le Rotix, A. Tranoy, "Les dimensions sociales de la romanisation dans la Peninsule Iberique des origines à la fin de l'Empire", in D.M. PIPPIDI (ed.), Assimilation et resistance à la culture gréco-romaine dans le monde ancien. Travaux du VT Congrés International d'Etudes Classiques, Paris 1974, p.101-106.

${ }^{13}$ ETIINNE, "Les syncretismes...", cit., p.155. 
per giungere a Cosus Mars, per passare poi a deus Mars ed infine al solo Mars.

Troppe sono però le zone di ombra delle nostre conoscenze sul mondo cultuale indigeno per la scarsità di testimonianze di cui disponiamo " e troppo alto il numero di divinità del pantheon romano-celtico per poter applicare una formula costante e rigida in tutti $\mathrm{i}$ casi. L'assimilazione o associazione tra le divinità indigene e quelle romane, infatti, può andare ben al di là del solo accostamento tra due dei che hanno caratteri e funzioni simili se non addirittura uguali: essa può rivelarsi anche in una molteplicità di accostamenti tra un dio romano e più divinità indigene come, ad esempio, nel caso di una dedica ex voto a Mars Latobius Marmogius Toutatis Sinatis Mogetius da parte di Caius Valerius Valerinus ${ }^{15}$ di Schloss Seggau dove l'interpretatio appare quasi esasperata. W. Spickerman ha ragione quando scrive "die Neubenennung der einheimischen Gottheiten darf nicht überwertet werden und beweist noch nicht eine gewollte und gelenkte Beeinflussung der einheimischen Religion durch die Eroberer" ${ }^{\prime 6}$. Inoltre va detto che a Roma stessa è attestato l'uso di deus e dea; rimane pertanto incerto il motivo per cui solo l'opzione di scegliere il prefisso sia considerato indice di romanizzazione e non anche il contrario visto che in ambiente romano sono presenti entrambe le possibilità che costituiscono, dunque, almeno teoricamente, tutte e due modelli da seguire. Inoltre, se il deus associato a divinità romane è inteso come un indicativo del numen della divinità soprattutto per chi appartiene al substrato indigeno, e una volta acquisita la totale coscienza della natura degli dei viene tralasciato, come giustificare la sua presenza associata a nomi di divinità di chiara órigine indigena per le quali non vi è un diretto parallelo romano, come ad esempio Sucellus ${ }^{17}$ ?

"Per questo aspetto vedi M. RADNoTI Alföl.DI, "Zur Frage der interpretatio romana", in Festschrift für Günter Smolla (Materialien zur Vor- und Frugeschichte von Hessen 8), Wiesbaden 1999, p.596.

${ }^{15}$ E. Wribler, Die römerzeitlichen Inschriften der Steiermark, Graz 1969, p.222-223, n.166.

"W. SPIlcki:Rmann, "Aspekte einer neuen regionalen Religion und der Prozeß der interpretatio im römischen Germanien, Rätien und Noricum”, in Römische Reichsreligion und Provinzialreligion, Tübingen 1977, p.152.

${ }^{17}$ In generale su questa divinità vedi Keunk, s.v. Sucellus, in RE, VII; 2, Stuttgart 1931, coll. 515-540; M. Chassaing, Une passion: l'archéologie. Le dieu au maillet, Orbec 1986; G. BARATTA, Una divinità gallo-ronmana: Sucellus. Un'ipotesi interpretativa, in Archeologia Classica, XLV, 1, 1993, p.233-247; G. BaratTa, "Sucellus", in Enciclopedia dell'Arte Antica 
La difficoltà nell'affrontare la questione nasce anche dal fatto che ignoriamo nel dettaglio come avvenisse la commessa di un altare o di una stele votiva e non sappiamo sulla base di quali elementi in concreto avvenissero le scelte. E' difficilmente immaginabile che tutto l'impianto della stele e dell'altare sia frutto della volontà del committente che avrà scelto invece tra una serie di modelli disponibili nell'officina lapidaria. Anche tra i testi vi saranno state diverse opzioni e non è escluso che la scelta finale fosse dovuta anche ad altri fattori legati ad esempio all'iconografia $o$, più ancora, di natura economica. E' plausibile supporre che il gestore dell'officina, proponendo cliché epigrafici e cartoni iconografici, condizionasse di fatto la selezione finale del cliente e giocasse dunque un ruolo da non sottovalutare nella trasmissione di elementi della romanizzazione.

L'interpretatio, che in genere si ricerca nell'ambito della parola scritta attraverso i dati epigrafici, si rivela anche nell'iconografia delle divinità del pantheon romano-celtico dove si assiste ad accostamenti e sovrapposizioni tra elementi indigeni e romani. In questo caso devono aver giocato di certo un ruolo importante mode e botteghe e soprattutto i cartoni che erano in circolazione. Non sempre è facile ricostruire quale sia l'apporto dei Romani e quali invece gli elementi indigeni per la scarsa conoscenza che abbiamo in questo settore per i periodi preromani. Nell'immagine generale delle divinità possono ravvisarsi evidenti elementi di classicismo, dovuti ad esempio all'adozione di determinati modelli, così come forme di espressione iconografica improntate ad un'arte provinciale: indipendentemente da ciò gli attributi ed alcuni atteggiamenti che fanno parte del carattere peculariare delle singole divinità rimangono costanti quali elementi identificativi del dio stesso. La distribuzione delle divinità sul territorio e il fatto che uno stesso dio assuma caratteri diversi in luoghi diversi evidenzia come la maggiore o minore commistione tra le divinità romane ed indigene o la preponderanza delle une rispetto alle altre sia legata a specifici fattori storici, politici ed economici che condizionano i culti e si riflettono in essi. Ciò è evidente ad esempio nel caso del culto di Sucellus tra i cui attributi, nelle regioni vinicole della Gallia, compare una botte. Il dio, che nella sua essenza e nell'iconografia richiama il romano Silvanus, assume qui

classica e orientale, Supplemento 1991-1994, V, Roma 1997, p.482; A.M. NAGY, s.v. Sucellus, in LIMC VII, 1, p.820-823; S. Nemetr, "Cultul lui Sucellus - Dis Pater şi al Nantosueltei Proserpina în Dacia romană", in Ephemeris Napocensis VIII, 1988, p.94-121. 
un valore aggiuntivo che ne fa una divinità legata prevalentemente alla viticoltura, una importante risorsa economica di queste zone ${ }^{18}$.

La formazione di un nuovo pantheon nato dalla commistione di quello romano e di quello indigeno comporta anche una interpretatio nell'architettura sacra. Soprattutto in Gallia e Germania ne rimangono evidenti tracce nel perdurare di un modello templare, il fanum, realizzato in epoca romana sulla base di una tipologia precedente ma con tecniche e materiali costruttivi nuovi rispetto a quelli tradizionali e arricchito di elementi decorativi desunti dal mondo classico. Un sintomatico esempio di convivenza, commistione e sovrapposizione di architetture religiose di estrazione indigena e di tradizione classica è offerto dall'area sacra di Altbach a Treviri". Strettamente legati al mondo indigeno, ma permeati della nuova cultura di cui rimangono le tracce nell'uso di iscrizioni votive e rilievi rupestri, sono i santuari boschivi, come ad esempio quelli di Artiona a Ernzen $^{20}$ e di Sucellus e della sua paredra Nantosuelta a St. Ingbert-Sengscheid ${ }^{21}$, entrambi nel Saarland, e in tutti quelli di sorgente come nel caso della Fonte do Idolo di Braga ${ }^{22}$.

L'interpretatio intesa come genesi di un nuovo pantheon nato dalla commistione di elementi romani ed indigeni, definita da Spickerman ${ }^{23}$ "bodenstäniger Kult", è probabilmente da considerarsi un fenomeno soprattutto iniziale legato in particolare alla conquista e alla prima fase di organizzazione del territorio. E' difficilmente pensabile che a molta distanza dalla conquista dei territori si facessero ancora nette distinzioni tra dei romani, indigeni ed "interpretati" e che questo nuovo pantheon non fosse, invece, già pienamente interiorizzato e vissuto come tale dalle diverse componenti sociali.

"BARATTA, "Una divinità...", cit., p.238.

19 E. Gost, Der gallo-römische Tempelbezirk im Altbachtahl zu Trier (Trierer Grabungen und Forschungen 8), Mainz am Rhein 1972.

* Cfr. AA.VV., Religio Romana. Wege zu den Göttern im antiken Trier; Trier 1996, p.184-185 e la bibliogragfia citata.

${ }^{21}$ cfr. AA.VV. Dic Römer an Mosel und Saar. Zeugnnisse der Römerzeit in Lothningen, in Luxemburg, im Raum Trier und im Saarland, Manz am Rhein s.d., p.164-165, n.105b e la bibliografia citata. In generale su Nantosuelta vedi F. Heichlilhism, s.v. Nantosuelta, in RE XVI, Stuttgart 1935, coll. 1683-1684; G BaraTTa, Nantosuelta, in Enciclopedia dell'Atte antica classica e orientale, Supplemento 1970-1990, III, Roma 1996, p. 857-858; S. NlimiTi, "Eine donauländische Variante der Göttin Nantosuelta”, in Latomus 60, 2001, p.160-166.

${ }^{2}$ J.M. Garcia, Religiões antigas de Portugal. Aditamentos e observacões às "Religioes da Lusitania" de J. Leite de Vasconcelos, Lisboa 1991, p.340-341, n.174.

${ }^{23}$ Spieckermann, "Aspekte...”, cit., p.152. 


\section{Conclusioni}

Allo stato attuale delle conoscenze sfuggono molti elementi, soprattutto quelli legati alla cultura indigena, per poter giudicare e comprendere bene il fenomeno dell'interpretatio. Quanto fatto da Cesare e Tacito, cioè la traduzione in termini latini di una realtà a loro estranea, per renderla comprensibile al lettore, è un processo unidirezionale che va dal mondo romano a quello conquistato e che non prevede alcun tipo di commistione e sovrapposizione. Si tratta in effetti di una semplice traduzione in termini di categorie logiche note di una realtà a loro estranea perché potesse essere recepita dal lettore. Diverso è invece il valore che la storiografia attribuisce al termine interpretatio, pur mutuandolo da questi due passi, poiché gli attribuisce un senso più profondo di "revisione", "reinterpretazione", sottindendendo fenomeni di sincretismo, sovrapposizione, scambio o commistione di caratteri formali e di contenuto tra le divinità.

Noi conosciamo i risultati di un processo di cui è difficile identificare $\mathrm{i}$ meccanismi e i fattori che ne sono alla base. Non si tratta, infatti, di un fenomeno semplice ed unitario da ricondurre a formulazioni schematiche che non sarebbero applicabili alle tante e diverse realtà che compongono i territori delle province dell'impero corrispondenti all'odierna Europa. Diverso e non omogeneo è il substrato indigeno con il quale viene in contatto Roma, questo varia a seconda dei luoghi geografici e della loro storia, del carattere maggiormente urbano o piuttosto rurale, della situazione economia, della viabilità e di numerosi altri fattori ancora. L'influsso di Roma sulla cultura religiosa indigena avviene inoltre in diverse forme e con varie modalità. Come scrive J. Beaujeu ${ }^{2 t}$ esso può essere diretto, ad esempio attraverso manifestazioni religiose ufficiali, tramite il culto imperiale o per mezzo di culti importati dai coloni, dai civili e dai veterani, oppure indiretto, cioè mutuato dai mercanti, venuto con viaggiatori, funzionari, introdotto da schiavi di varia origine ecc....

Di questi numerosi fattori che condizionano lo sviluppo e la formazione dei culti, dunque il manifestarsi dell'interpretatio, è emblematico, ad esempio, il caso della Penisola Iberica dove, come aveva già messo in evidenza a suo tempo da $\mathrm{J}$. Toutain ${ }^{25}$ e come riconfermano anche lavori più recenti, risulta

${ }^{21} \mathrm{~J}$. BeAljet, "Cultes locaux et cultes d'empire dans les provinces d'Occident aux trois premiers siècles de notre ere”, in PIPPIDI (ed.), Assimilation et resistance..., cit., p.434-435.

${ }^{25}$ J. Tottain, Les cultes païens dans l'empire romain, III, Paris 1920, p.183 
chiara la discrepanza nell'ambito cultuale tra il settore nord-occidentale e la fascia mediterranea.

Se si considera che il mondo religioso non costituisce una sfera a se stante ma è il riflesso della realtà sociale, politica e culturale di un determinato momento e luogo, l'interpretatio in senso lato costituisce un fenomeno che va al di là del solo ambito cultuale e investe molti altri aspetti della vita civile, spazi privati e pubblici, istituzioni, cultura materiale e patrimonio spirituale. L'interpretatio si configura come un elemento importante nello sviluppo della cultura delle province romane d'occidente e riunisce in se i fenomeni così detti di romanizzazione e resistenza al contatto con il mondo romano ${ }^{26}$.

${ }^{2} \mathrm{Vd}$. a questo proposito gli atti del convegno PIPPIDI (ed.), Assimilation et resistance..., cit. 


\title{
IDENTIDADE E ALTERIDADE JUDAICA EM ROMA
}

\author{
Nuno Simões Rodrigues \\ (Universidade de Lisboa)
}

\begin{abstract}
Based on a corpus of archaeological and epigraphic documents and on an amount of literary information, that covers the period from the I" century b.C. to the III ${ }^{\text {di }}$ century A.D., we have concluded that the Roman Diaspora was one of the biggest Jewish centres outside Israel, in Antiquity. Although Jews voluntarily maintained their marks of ethnic and religious exclusiveness, the available data show us that, to a certain point, they were well inserted in Roman society and world. The use of Greek as daily language and the frequent use of Latin names can prove it. But, the same Jews desire to keep up Jewish appearances, by maintaining their practices, the same that marks the difference between them and the Romanitas. Among these, we can find monotheism, aniconism, circumcision, proselytising and the Sabbath issue. By pointing them and criticising them, the Greek and Roman authors are marking and showing the Otherness of the Jews. In these sources, we can understand the levels of Jewish identity and otherness, and how the Jews have inserted themselves, or not, in the Roman society and world. So, by studying this problem we are looking at the first centuries of Jewish installation in what became Europe and the way they were seen.
\end{abstract}

Com base num corpus documental constituído pelo espólio arqueológico-epigráfico (sobretudo epitáfios) de seis catacumbas judaicas, localizadas em Roma, e por um manancial de informação literária, que se encontra em vários autores, desde Cícero a Santo Agostinho, passando por Horácio, Vergílio, Ovídio, Séneca, Petrónio, Fílon e Josefo, concluímos que a diáspora romana da Antiguidade era um dos maiores centros de judaísmo fora de Israel. De acordo com os dados disponíveis, é possível afirmar que, entre os séculos I a.C. e III d.C., existia, em Roma, um número considerável de habitantes de origem e confissão judaica, talvez o suficiente para perfazer cerca de 
5\% da população do caput orbis. Essa comunidade poderá ter chegado a Roma em dois momentos, um deles relacionado com a história dos Judeus (a conquista de Israel pelos neo-Babilónios, que teve como consequência a deportação das elites e de massas e terá implicado movimentos migratórios significativos) e o outro relacionado com a história de Roma, mais concretamente com as Guerras Púnicas (com a destruição de uma sociedade de origem semítica e na qual se encontrariam muitos judeus). Não será improvável que, entre os prisioneiros púnicos trazidos para Roma e entre os imigrantes voluntários provenientes nessa ocasião do Norte de África para a Península Itálica, tivessem vindo muitos judeus. Consideramos mesmo esta a hipótese mais verosímil para explicar a chegada dos judeus pioneiros a Roma. Os descendentes de Abraão teriam, porém, continuado a afluir à Urbe e, no espólio arqueológico judaico da Cidade, encontramos referências a indivíduos provenientes de várias regiões do Império, designadamente da Judeia, da Ásia Menor, do Norte de África em geral, de Alexandria, e da Grécia'.

O estado actual dos nossos conhecimentos permite-nos afirmar que não existia, na Antiguidade, um ghetto em Roma, como terá havido, ainda que momentaneamente, em Alexandria. Nem sequer haveria mesmo um bairro exclusivamente judaico, como existia nessa cidade do Egipto helenístico. Em Roma, os Judeus habitavam diversas áreas da cidade, ainda que com uma especial concentração no Transtiberino, visto que é a região a que pertence e diz respeito a maioria dos vestígios arqueológicos, epigráficos e literários judaicos. Mas havia também judeus na Subura, no Campo de Marte ou em outras áreas marginais. As elites judaicas terão chegado mesmo ao Palatino?.

Exceptuando Jerusalém, nenhuma outra cidade da diáspora terá possuído tantas sinagogas como Roma, não sendo de excluir a hipótese de que talvez até existissem mais, cujo registo se terá perdido. Mas é no fenómeno da catacumba que melhor apreendemos o carácter do Judeu de Roma. O uso de catacumbas como necrópoles corresponde à concepção de grupo étnico-religioso. Trata-se da mesma ideia que preside à formação dos collegia, fazendo assim da catacumba um collegium post mortem. Esse é um espaço e uma via para que a comunidade mantenha a sua identidade. As catacumbas judaicas da Cidade baseiam-se em modelos funerários pré-existentes. Como referimos, conhecemos seis delas, descobertas entre os séculos XVI e XX.

\footnotetext{
' Sobre o desenvolvimento destas problemáticas, ver Rodrigulis (2004) 37-96.

"Id., ibid.
} 
Apenas três, porém, continuam acessíveis. Nesses espaços, abunda a decoração constituída por simbólica judaica, como a arca da aliança, a menorah, o 'etrog, o lulav, a romã, a mandrágora, o shofar e o punhal ritual da circuncisão. As epígrafes e graffiti que nelas se encontraram dão existência material aos mortos que lá foram sepultados ${ }^{3}$.

A organização de tipo colegial que se associa à catacumba reproduz a realidade dos vivos. Outras comunidades de estrangeiros deixaram poucos vestígios da sua organização e, nesse sentido, os judeus são quase caso único. Aliás, nestes reconhecem-se mesmo formas de estruturação praticamente sem paralelo entre outros grupos estrangeiros, talvez porque nunca nesses houve uma superestrutura ideológica tão forte como entre os judeus, a mesma que levou à criação das instituições. Efectivamente, a comunidade judaica de Roma estava bem organizada e estruturada de forma hierárquica. A hierarquia sinagogal sugere uma organização consciente, devendo corresponder a uma micro-

-sociedade também ela de parâmetros bem definidos e organizados, que iam da figura cimeira que assumia a responsabilidade ao sacerdote e ao pedagogo, responsável pela educação da comunidade‘. Esta hierarquia é compatível, todavia, com o que conhecemos de outros collegia de Roma, como os Fratres Aruales.

Estando inseridos em Roma, estes judeus distribuíam-se de acordo com os mesmos requisitos do resto da população da Urbe, isto é, inseriam-se nos quatro grandes grupos em que a população se dividia: serui (sem personalidade jurídica, mas com obrigações legais, estando sujeitos à jurisdição criminal, podendo ser punidos pelo senhor ou pelo Estado), peregrini (livres, fora da esfera do ius ciuile, porém sujeitos à coercitio dos magistrados e à jurisdição do praetor peregrinus; após a Constitutio Antoniana, em 212 d.C., este estatuto desapareceu), liberti/libertini (indivíduos emancipados, através da

${ }^{3}$ Id., ibid.

' P. PANAYI, Immigration, Ethnicity and Racism in Britain, 1815-1945, Manchester, 1981, 5, citado por Noy (2000) 158, afirma que a forma como os Judeus se organizam e comportam enquadra-se na definição moderna de "etnia» ou «afiliação étnica»: "the way in which members of a national, racial or religious grouping maintain an identity with people of the same background in a variety of official and unofficial ways». Noy continua: «The ways may include residence, marriage, and religious or social activity. In some cases, the sense of ethnicity can be encouraged from above, when leading members of an immigrant community, or even natives of the host community, develop institutions for religion, education or philanthropy targeted specifically at the immigrant group.» Ver ainda Ronkiguts (2004). 
manumissio, e granjeando assim a condição de cidadãos, ou não) e ciues romani (usufruindo de todos os privilégios e obrigações que a lei romana estipulava para os cidadãos de Roma, que podiam residir na Urbe, votar e ser expulsos da Cidade apenas depois de uma condenação num julgamento, podendo ainda apelar para uma autoridade superior, segundo o que estabelecia a prouocatio) $)^{5}$ Fílon de Alexandria afirma, contudo, que os judeus romanos do tempo de Augusto eram, na sua maioria, libertos, emancipados por manumissão, por terem sido anteriormente prisioneiros de guerra ${ }^{6}$. Para a Antiguidade Tardia, com o advento do cristianismo, há legislação mais específica em relação à condição jurídica dos judeus?. A relativa abundância de nomes gentilícios romanos entre os judeus sugere a existência de importantes redes clientelares verticais entre aqueles e as mais importantes famílias da Urbe. Outros, como os pertencentes às mesmas sinagogas, sugerem redes de solidariedade horizontais. Também a sua condição sócio-económica seria variada, encontrando-se judeus exercendo profissões como pintor, comerciante, artesão, actor, cantor, professor, jurista, ou até mesmo desempenhando importantes cargos políticos, como no caso de Tibério Júlio Alexandre, provando a integração judaica na sociedade dominante, ainda que, por vezes, como no exemplo citado, com o sacrifício da manutenção da prática religiosa dos seus antepassados ${ }^{8}$. Estes dados salientam o carácter urbano da comunidade e se o cristianismo virá a ser uma religião essencialmente urbana, talvez deva muito disso ao judaísmo romano.

O carácter religioso destes judeus é avaliado por adjectivos e qualificativos que surgem na documentação e que descrevem a sua crença e posição perante ela. Confirmando a sua inserção no mundo helenístico, os judeus de Roma falam essencialmente grego, sendo essa a língua a que a maioria recorreu para exprimir as suas mensagens para e da eternidade. Esta opção está de acordo, também, com o seu carácter oriental ou com o movimento que levou à tradução dos Septuaginta. Nesse sentido, o grego funciona mesmo como uma língua de resistência cultural. Alguns recorrem ao latim, talvez sintoma de um grupo mais romanizado ou mais próximo do poder ou de uma elite político-social. O hebraico/aramaico limita-se a expressões formulares,

${ }^{5}$ Seguimos a sistematização de Rabello (1980) 662-762; Gaudemet (1988) 339-359; e RutGers (1998) 175.

${ }^{6}$ PH., Legat. 155-156.

'Ver exemplos em Rutgers (1998) 92, n.121.

"J., AJ20.100-101. Sobre o cóntexto desta questão, ver Rodrigues (2004) 559-636, 683-731. 
relacionadas com mensagens de carácter apotropaico. Talvez isso não signifique o desconhecimento da língua; mas significa por certo o seu desuso generalizado, que conduziu ao seu desconhecimento.

Em contraste com o uso do grego, abundam os nomes de origem latina entre os judeus de Roma. Isso leva a crer que são as necessidades práticas que impõem o uso da língua oriental, que predominaria nas áreas de residência da maioria dos judeus romanos, de origem imigrante. Essa realidade atesta-se pela relação nome/catacumba. $\mathrm{O}$ apelo da cultura dominante, contudo, levaria à imitatio e adopção da onomástica que se identificava com a supremacia política. Em segundo lugar vêm os nomes gregos e só em terceiro os de origem semítica. Esta situação parece traduzir um progressivo abandono de uma determinada matriz que coincide, porém, com a manutenção das suas simbólicas iconográficas, como se se reconhecesse apenas nelas o elo com a origem, a religião e a comunidade. As marcas iconográficas parecem delimitar espaços, reclamando assim um pedaço de Israel dentro de Roma.

Os materiais dos sarcófagos judaicos de Roma fornecem informação significativa quanto ao tipo de crença destes judeus. Neles, encontramos uma gramática iconográfica declaradamente judaica, mas também outra não judaica, que nos permite uma leitura mais abrangente do carácter religioso desta população. A existência de figuras humanas e animais, em plena contradição com o que se pode ler na Torá, as representações de Erotes, das Musas, da Medusa, de personificações das estações do ano ou de divindades como Dioniso, Vénus e a Vitória levantam diversos problemas: o da eventual reutilização destes materiais e dos espaços a eles dedicados (que poderia explicar a presença dos elementoßs estranhos ao judaísmo), mas também o da evidente aceitação dessa iconografia, ainda que provenha de materiais reutilizados (o que neutraliza por completo o argumento anterior). Logo, pensamos estar em condições de concluir que existia, pelo menos na época destas catacumbas e neste círculo, uma maior abertura ao código cultural não judaico, que coincide com a adopção de onomástica greco-latina teofórica e, inclusivamente, com determinadas actuações políticas, demonstrando uma vez mais ampla inserção na sociedade de acolhimento. Os frescos que decoram alguns destes espaços obedecem à mesma regra, sendo inclusivamente possíveis leituras neo-platónicas nas suas gramáticas, o que significa que, além do grego, se adoptava também a sabedoria grega. Podemos assim afirmar que os judeus romanos, talvez como muitos dos seus concrentes, não só adoptaram modelos políticos e linguísticos do mundo greco-romano que os envolvia, como também matrizes 
religioso-antropológicas. As semelhanças com o dionisismo e o orfismo, que alguma da literatura não-judaica outrossim reconhecerá, são evidentes.

Se houve uma facção judaica mais ortodoxa, outra houve mais permeável. Se uma se opôs à secessão cristã e outra a ela deu origem, alguma se abriu à cultura que a rodeava, albergando elementos não judaicos. Talvez esta tenha sido a facção do judá́smo que Roma deixou sobreviver no seu seio ou, melhor, a que conseguiu sobreviver, após 70 e 135 d.C. O mesmo tipo de diferença parece ter existido em Alexandria. Aliás, a percepção de pelo menos dois tipos de judeus, de algum modo, espelha-se nas palavras de Tácito", de onde se depreende que se consideraria a existência de duas capitais judaicas: Cesareia, que evoca Augusto e é capital da Judeia, província romana; e Jerusalém, capital do judaísmo e dos Judeus, povo a neutralizar e, portanto, cidade a destruir.

Estes dados contradizem A. Momigliano, que, de acordo com a corrente historiográfica dominante nos séculos XIX e XX, tinha a comunidade judaica de Roma como uma realidade à parte ${ }^{10}$. Consideramos, portanto, que a ideia de isolamento deve ser revista e rejeitada. Há que perceber que se encontram elementos não judaicos inseridos em contexto judaico, porque estes judeus vivem num mundo não judaico, comportando-se por isso, em parte, como não judeus. Participaram desse modo no mundo estranho ao judaísmo que os rodeava. A interacção revela-se assim natural e necessária neste contexto, mas tem um limite e uma forma que corresponde a um determinado tipo de aculturação". A questão essencial, portanto, não é tanto averiguar graus de resistência, mas sim a forma como estes judeus integraram a cultura greco-romana no seu quotidiano: adoptaram nomes, iconografias, profissões, língua, tudo ao jeito greco-romano, porque estão nesse mundo ${ }^{12}$. Prova-se assim que podiam relacionar-se sem ser em termos religiosos. Aliás, a realidade é mais complexa do que isso: vivência religiosa, integração social e subsistência económica são os factores que condicionam e determinam a interacção. As línguas que falam, os poemas que usam nos epitáfios, muitos dos nomes, fazem com que se

"TAC., Hist. 2.78 .

${ }^{10}$ Como nota Rutglirs (1998) 74-75.

" Cf. RuTCilRs (1998) 35, para quem a aculturação não envolve necessariamente assimilação substancial; assimilação, porém, envolve sempre um grau considerável de aculturação. Assim, os judeus usam o grego, mas expressam as suas ideias judaicas; ou usam palavras já existentes, atribuindo-lhes um novo sentido. Do mesmo modo, usam sepulturas do mundo greco-romano, mas atribuem-lhes marcas especificamente judaicas.

${ }^{12}$ Assumimos aqui o Império Romano como uma realidade de essência greco-latina. 
diluam na população de Roma, acabando quase por ser simplesmente Romanos, com a particularidade de adoptarem e seguirem determinadas crenças específicas, como aliás acontecia com outros romanos. Mantêm, por isso, a sua identidade. Se não, teriam deixado de ser judeus e não deixaram de o ser. Resistem à diluição total por usarem marcas que os distinguem e identificam como grupo ou comunidade. Por sua vez, esta persiste numa ordem e hierarquia próprias, tentando sobreviver à macro-estrutura da sociedade romana que os envolve. Daí a organização sinagogal, os títulos, cargos e funções, os símbolos que trouxeram da sua cultura, que permite defini-los como «etnia judaica». Traduz-se assim, também, a sua tentativa de responder à neutralização do post mortem. Para o Romano, são apenas marcas que persistem em mostrar a diferença, o que para ele é, aliás, incompreensível. Porque se há-de distinguir da romanidade?

Desse mesmo Romano persistem, assim, atitudes que intendem salientar a alteridade, marcando precisamente o desejo do Outro à diferença. Alguns autores têm visto no êxito do judaísmo entre os não-judeus, em particular entre os Romanos, as causas de algum anti-judaísmo que muitos textos greco-latinos denunciam. É inegável que Séneca, Marcial e Juvenal, entre outros, exprimem opiniões muito pouco favoráveis em relação aos Judeus. Mas há que ter em conta que essas afirmações são o produto de uma conjuntura política de que fizeram também parte medidas repressivas em relação às comunidades judaicas de Roma que, de tempos a tempos, eclodiram na cidade. De qualquer modo, podemos analisar aquilo que, aparentemente, os Romanos sabiam acerca dos Judeus e o modo como se manifesta a alteridade e processa a elaboração da imagem representativa do Outro e, consequentemente, como, por oposição, se ganha consciência do Eu-romano, logo Europeu.

Quando analisamos os textos greco-latinos, produzidos por não-judeus, que abordam o judaísmo, percebemos que existe uma série de temáticas comuns a muitos deles. Grosso modo, essas fontes podem dividir-se entre as que tratam essencialmente de dados da conjuntura histórica judaica, quer per se, quer na relação com a evolução histórica de outras civilizações, designadamente a romana; e as que formulam juízos, tecem considerações e opiniões sobre os Judeus, as suas origens e carácter enquanto povo e religião. É nesta perspectiva que nos interessa a construção da imagem do «Outro-judeu»".

"A questão da alteridade é das mais pertinentes para perceber o etnocentrismo greco-romano e a construção da própria identidade, cf. SiLva (1999) 23-48. 
Uma das conclusões mais significativas a que Leon chegou no seu estudo sobre os judeus de Roma sintetiza-se nas seguintes palavras: "We have no reason to suppose, from the available information, that the religious ideas and practices of the Roman Jews differed in any material degree from those of other communities in the Diaspora.»" Nós acrescentaríamos: e ao nível do material iconográfico respeitante à prática religiosa é mesmo difícil perceber as diferenças que de facto marcam o contraste entre os judeus de Roma e os outros Romanos. Mas essa conclusão dificilmente Leon teria verbalizado. É claro que existem elementos característicos dos Judeus: a menorah é uma marca exclusiva sua, e depois há o shofar, o 'etrog, o Iulav. Mas estes elementos articulam-se com outros que estào longe de poderem ser considerados exclusivamente judaicos. Parece-nos antes que existe uma comunhão de simbólicas que é independente da definição de uma identidade étnica ou religiosa.

Por outro lado, apesar da integração, há marcas comportamentais que se podem também definir como exclusivas dos Judeus, não só em Roma, como por toda a diáspora. Referimo-nos às marcas universais do judaísmo que permitem identificar o "Judeu» em qualquer sítio em que esteja instalado. $\mathrm{Na}$ verdade, além destas, não existem quaisquer outras perceptíveis que possam definir o grupo como os «judeus de Roma»: a língua que usam é o grego, falado por todo o Mediterrâneo oriental antigo; os seus nomes variam entre a origem semítica, a grega e a latina; a iconografia a que recorrem não é exclusivamente judaica. É verdade que a organização da comunidade faz-se centrada na sinagoga e os cargos e funções são, aparentemente, comuns aos das outras comunidades da diáspora. A associação em si, todavia, encontra semelhanças em outras associações religiosas em Roma. Assim, que outros elementos podem marcar a diferença? Independentemente da imagem negativa ou positiva que se possa formular em cada autor que se refere aos Judeus, há um grupo de tópicos recorrentes que servem para a composição da sua imagem. Trata-se dos temas do monoteísmo anicónico, da dieta e tabus alimentares, do respeito pelo Sábado, do proselitismo e da circuncisão. Isto é: as marcas comportamentais, não sendo esta última exclusiva dos Judeus, mas que, em conjunto com as outras, contribuía para a sua definição enquanto grupo ${ }^{15}$.

"LEON (1995) 24.4.

15 No espaço não judaico, algo semelhante pode ser percebido na noção de ciuis: é um ciuis aquele que tem algo em comum com outros em relação a uma ciuitas, como estruturas 
No seu tratado em defesa do judaísmo, Josefo testemunha que estas práticas eram escrupulosamente observadas onde quer que existissem judeus ${ }^{16}$. Estes temas correspondem, fundamentalmente, à marcação da diferença. $\mathrm{O}$ separatismo e auto-diferenciação judaica opõem-se ao espírito helenístico de enkyklios paideia, que influenciava a mentalidade política romana. Basta isso para predispor ao conflito. Assim, apesar de existirem tendências monoteístas e até anicónicas no mundo greco-romano, essa não é a vocação geral da sua religiosidade ${ }^{17}$. Um culto sem imagens favorecia a ideia de ateísmo entre algumas posições anti-judaicas mais radicais, chegando-se a sugerir adjectivos para a caracterização do Deus judaico como ignotus e agmostos. Talvez radique nesta questão, aliás, o célebre discurso de Paulo de Tarso em Atenas, dedicado «a um deus desconhecido»" ${ }^{18}$. Também por razão do seu aniconismo, são os Judeus em grande parte segregacionistas, visto que a maioria das manifestações religiosas do seu tempo era icónica. Derivada dessa característica, associada ao facto de o judaísmo do tempo de Jesus utilizar o termo em substituição do nome de Deus e desta própria designação, deverá ser a noção de que os Judeus adoravam o céu". Outros simplesmente associam Javé às divindades do seu sistema, numa atitude de interpretatio perfeitamente compreensível dentro da concepção greco-romana ${ }^{20}$, ou reagem com uma leitura teocrética ${ }^{21}$. Estas são atitudes próprias dos intelectuais greco-romanos, entre os quais incluímos Josefo e Plutarco, que têm consciência desse tipo de conceptualização ${ }^{22 .}$

Alguns textos, porém, reproduzem uma tradição que se instalara entre Egípcios helenizados, Gregos e Romanos, que afirmava que os Judeus adoravam um burro ${ }^{23}$. Algumas variantes referem que era a estátua de um burro que

urbanas, direitos, instituições e relações sócio-económicas. Mas o judeu podia também estar inserido neste grupo, que é mais abrangente. Cl. WAL.BANK (1972) 14.5-168.

"J. Ap. 2.282.

"O monoteísmo é razào para comentário da parte de TAC., Hist. 5.5.4, por exemplo.

"Act. 17,23: Agmosto Theo; em latim, Ignoto Deo.

"Hecat. Alid., Aegyptiaca, apud D.S. 40.3; PETr., frag. 37; MACr. 2.4; STr. 16.2; Juv. 14.96-106; a ausência de imagens no culto é também referida por TlirT., Apolog. 24.5. Sobre esta questão, ver Ronrigulis (2004a) 85, 93 n. 35.

${ }^{20}$ VAr., apud August., De cons. Euang. 1.23.31.

${ }^{21}$ Fusão das várias divindades numa só, cf. VAR., apud AuiguisT., C.D. 4,11.

"2. Rodrigues (2005) 435-438.

${ }^{23}$ O Autor mais antigo conhecido a ter divulgado essa crença terá sido Mnáseas de Pátaros, no séc. III a.C.; J., Ap. 2.112-114. 
se encontrava dentro do Templo, em Jerusalém, ou a da cabeça de um burro, ou a de um burro com um homem barbado sentado sobre ele, possivelmente Moisés. Este aspecto da onolatria aparece em diversos documentos e ultrapassou as fronteiras do judaísmo, visto que ressurge associado ao cristianismo ${ }^{21}$. Numa provável alusão a esta religião, conhecemos, inclusivamente, a imagem dẹ um homem com cabeça de burro, crucificado, sendo adorado por uma segunda figura, lendo-se a inscrição "Alexâmenes adora o seu deus»". Mas, por que razão se associam os Judeus à onolatria? Josefo cita uma história contada por Ápion, onde o tema aparece ${ }^{26}$. Posidónio e Apolónio Mólon recuperam-no. Alguns historiadores sugeriram que se tratava de uma característica dos povos da Síria, em geral, depois restringida aos Judeus em particular. Mas S. Reinach, na sequência de outros filólogos, recorda que, na história de Siquem e Dina, o jovem é filho de Hamor, nome que, em hebraico ( $h m^{\prime}$ ' $)$ significa «burro»". Isso poderia traduzir a ideia popular difundida em Israel, segundo a qual, entre os Siquemitas, incluídos no grupo dos Samaritanos, se praticava a onolatria. Talvez se tratasse de um vestígio ainda totémico. Segundo Reinach, é possível que tenham sido os Gregos da Ásia Menor a relacionarem o culto do burro com os Hebreus, e posteriormente os Judeus, em geral. Ainda para mais, corriam entre esses Gregos algumas histórias em que o burro tinha protagonismo, nomeadamente as de Ocno, Midas e Priapo.

${ }^{21}$ D.S. 34-35.1.3; J., Ap. 2.79-88, 112-120, citando Ápion; TerT., Ad nat. 1.14; Apolog. 16.1-3 (onde o Autor aponta as contradições de Tácito e se lê Nam, ut quidam, somniastis caput asininum esse deum nostrum. Hanc Connelius Tacitus suspicionem huiusmodi inseruit); Min. Félux, Octávio 9.3.

${ }^{23}$ Trata-se de um célebre graffito encontrado no Palatino, em Roma. Ver bibliografia citada em SCHÄFli (1997) 233, n.142. A ideia de que o graffito se refere ao cristianismo não é aceite por todos os investigadores, como lembra REINACH (1996) 650, salientando a seita gnóstica que adorava Tífon-Set. Ainda assim, há que recordar que a associação dos Judeus com essas figuras era também feita por autores greco-latinos, cf. Plit., Is. Os. 31, e TAC., Hist. 5.2.2. Em Plutarco, o burro aparece como ajudante do gigante Tífon, que veio a tornar-se precisamente o pai de Hierosólimo e de Judeu, epónimos do povo judaico. A ajuda dada pelo burro a Tífon justificaria a veneração dos Judeus por esse animal. Daí alguns Romanos chamarem aos judeus e aos cristãos asinarï e representarem Jesus com orelhas de burro, com um dos pés em forma de casco, vestindo uma longa túnica e tendo nas mãos um livro.

${ }^{26}$ Cf. J., Ap 2.112-114.

${ }^{27}$ RliNACH (1996) 647-650; cf. Gn 34. Este Autor apresenta ainda um raciocínio de base filológica para a forma Iao, que encontramos em D.S. 1.94.2 e em MACR. 1.18 (associado à palavra que em egípcio significaria «burro»), e para a palavra grega que designa burro, onos. SCHÄFlR (1997) 60, recupera esta ideia da origem egípcia da tradição. Sobre a forma Iao, ver ainda KRAABEL (1979) 41-58. 
Os mistérios eleusinos parecem também ter-lhe dado alguma importância ${ }^{2 n}$ e o carácter associativo do judaísmo poderá ter sugerido a afinidade temática. Também o dionisismo estava fortemente conotado com o burro: este animal representava os trabalhos, a humilhação e o sofrimento por que um ser humano tem de passar antes da salvação ${ }^{29}$. Nesta perspectiva, as associações de Javé a Dioniso fazem sentido ${ }^{30}$. Mas na própria cultura hebraica o burro tinha algum protagonismo: recordamos os episódios de Balaão, em que uma jumenta fala; de Saul, que sai de casa do pai em busca de jumentos perdidos e encontra um reino, Israel; Salomão monta a mula de David para ser ungido rei; a profecia de Zacarias, em que o Messias entra na Cidade Santa montado num jumento, posteriormente relacionada com a figura de Jesus, como demonstram as tradições que colocam o burro no momento do nascimento do Nazareno e associam a figura de Maria ao mesmo animal, no momento em que foge para o Egipto ${ }^{31}$. Talvez algum ou o conjunto destes temas motivasse a formulação da ideia da onolatria judaica, designadamente a ideia de Moisés sentado sobre o animal com um livro nas mãos. Ocorre-nos ainda a relacionação da imagem do burro de ouro mencionada em alguns textos com a do bezerro de ouro, citado no $\hat{E x o d o}$ ou a da serpente de bronze ${ }^{32}$. Apesar da diferença de animais, trata-se de formas de zoolatria relacionadas com Israel, pelo que a questão da onolatria não será um dado completamente estranho a essa cultura. Talvez as razões da ideia da adoração do burro, presente entre alguns não-judeus, se encontrem nas hipóteses acima sugeridas. Ou talvez lendas derivadas dos messianismos popularizados tivessem sido transmitidas deformadamente. A explicação avançada por Tácito, e lembrada por Plutarco, por exemplo, de carácter anedótico, funciona, todavia, como etiologia de algum modo convincente: teria sido montado em cima de burros que Moisés, enquanto chefe do povo no deserto, teria encontrado a água que tanta falta lhes fazia ${ }^{33}$. Também a história contada por esse autor latino radica num tema

${ }^{2 n}$ Ar., Ra. 160, 186; cf. 293; Plu., De Tranq. anim. 473c.

* Alguns textos onde estas ideias estão patentes: Ar., Ra. 159; Juv. 6.334; Ali., NA 10.28; Plu., Ant. 10.28; Apul., Met. 7.21; 10.22-23; Keuls (1997) 41-70; FicK-Michli. (1991) 333-338. A iconografia encontrada em Pompeios é importante para o estudo desta relação.

${ }^{30}$ Cf. e.g. RoDrigutis (2005) 435-438.

"NI Nm 22,1-35; ISm 9,3; IRs 1,33; Zc 9,9; Mt 21,1-6; Mc 11,5-10; Pseudo-Mt. 14.

${ }^{32} E_{X}$ 32,1-29; $N_{m}$ 21,8-9; em 2Rs 18,4, há evidência do culto desse objecto até ao tempo de Ezequias.

"a TAC., Hist. 5.3.2; Plu., Quaest. Conu. 4.4.5; sobre a falta de água no deserto, ver $E_{X}$ 17,1-7; Nm 20,2-13. Esta etiologia é considerada uma Kriegslistgeschichte. 
da literatura judaica: a falta de água no deserto. Gostaríamos ainda de recordar a obra de Apuleio. É que no Asinus aureus reencontramos muitos dos temas das religiosidades orientais, designadamente ecos do cristianismo e em parte até do judaísmo, num contexto isíaco, e onde o protagonista é precisamente um burro ${ }^{3 t}$. Na Antiguidade, o burro tinha um simbolismo duplo: tanto era tido como animal demoníaco, expressão do mal e lascivo, como é o animal escolhido para carregar os fardos sagrados. Entre os Judeus parece ter assumido esta faceta. Entre Gregos e Romanos, sobretudo aquela.

Ainda relacionada com a imagem da divindade está a alegação de que esta exigiria sacrifícios humanos. A ideia aparece em Josefo, que a atribui a comentadores da sua religião, como Posidónio e Ápion ${ }^{35}$. Com ela, pretendese acentuar a concepção de misoxenia e de misantropia atribuída aos Judeus. Mas a história que Josefo conta, a de um estrangeiro encerrado no Templo, a ser alimentado, à espera de ser sacrificado ao Deus dos Judeus, protagonizada por Antíoco Epifânio da Síria, é bastante semelhante à que corria no mundo grego acerca de Busíris ${ }^{36}$, personagem sediada no Egipto que nos leva a relacionar de novo as coisas judaicas com o país do Nilo. Estas atribuições formulam uma imagem dos Judeus como uma associação secreta que conspira contra estrangeiros e cujos rituais de adoração reforçam a ideia da conspiração. Essa parece-nos ser uma das ideias-chaves que circulavam entre Gregos e Romanos acerca dos Judeus. Não seria, porém, a única ${ }^{37}$.

Em relação à dieta, há que referir as restrições alimentares, regulamentadas em vários passos bíblicos ${ }^{98}$. O consumo da carne de porco, todavia, é o aspecto mais marcante, não havendo praticamente referências a outras interdições, entre os autores greco-latinos, quando o Levítico não é parco nelas. Porquê o porco? Provavelmente porque se tratava de um dos animais mais consumidos na bacia mediterrânea, sendo por isso uma das bases alimentares para muitos. Mas este animal está bastante presente no imaginário greco-latino, considerado purificador por uns e fazendo mesmo parte do trio que

"APUL., Mct., passim. O tema será igualmente tratado por Luciano de Samósatos.

${ }^{25} \mathrm{~J} .$, Ap 2.89-96, 121-124.

${ }^{3 *}$ Em ambos os temas se salienta um «misohelenismo». HD\%. 2.43-4.5; D.S. 1.17, 4.5; 4.18, 27; Apolicon., Bibliotheca 2.5.11; Eurípides havia escrito um drama satírico sobre o tema, hoje perdido; mas a tragédia do mesmo Autor, Ifigénia entre os Tauros, abordava uma situação semelhante de sacrilício de estrangeiros e a mesma ideia aparece em Hcl. 430-431.

${ }^{37}$ WARDY (1979) 594-644.

${ }^{3}$ Lv 11,2-3; Dt 14,8; cf. Is 65,4. 
formava os suouetaurilia (um dos principais sacrifícios animais entre os Romanos), constituindo este grupo de animais a base do fornecimento de carne desta população ${ }^{39}$. A estranheza da abstenção do consumo da carne suína levou, por isso, às mais diversas formulações pela parte não-judaica: os Judeus não comiam o porco porque ou o adoravam ou o abominavam, chegando a mencionar-se o seu sacrifício aos deuses ou a sua relação com a lepra, por causa da qual teriam sido expulsos do Egipto, consoante a posição do autor ${ }^{\text {". }}$. Mas, de algum modo, essa característica insere também os Judeus nos povos bárbaros ou grupos filosófico-religiosos sectários, como os Neo-Pitagóricos, que se refreavam de determinados géneros alimentares. Em relação a este assunto, parecem-nos paradigmáticas as frases de Juvenal, que se refere a Agripa e Berenice como originários do país onde «uma clemência tradicional deixa os porcos morrerem de velhice» (uetus indulget senibus clementia porcis)" ${ }^{\text {" }}$ e de Macróbio, autor do século V, que atribui a Augusto: «Melhor é ser o porco de Herodes que o seu filho» (melius est Herodis

${ }^{30}$ Efectivamente, entre Gregos e Romanos, o porco era bastante apreciado para consumo, sendo inclusivamente usado para sacrifícios religiosos; ver ApIcits, De re coquinaria, passim, onde 70\% das receitas de carne incluem porco; Var., R. 2.4.3; Gal., Libr: Propr: 6.620 ('este Autor recorda que a carne de porco é bastante semelhante à humana, sendo talvez essa uma das razões do tabu); note-se, contudo, que ATH. 9,18, refere que os Cretenses se abstinham igualmente de consumir porco, em memória de uma porca que havia ajudado Zeus. Soller (1973) 943-955 sugere que as proibiçōes do Levítico eram apropriadas à cultura e ao clima do Próximo Oriente; no caso do porco, M. HARRIS (1987) 59-60 considera que a sua abominação advém do facto daquele ser considerado um animal da cultura sedentária e os Hebreus serem originalmente nómadas. No século I d.C., Erociano, num texto em que glosa Hipócrates acerca da epilepsia, afirma que os Judeus se devem de facto abster da carne de porco, pois se a epilepsia é um mal divino, se estes comerem o que o seu Deus lhes proibiu poderão ser atormentados com tal mal. De igual modo, os Egípcios devem abster-se de carne de ovelha ou de cabra, ERoT., Vocum Hippocraticarum Collectio cum Fragimentis F33. Sobre as funçòes, religiosas, alimentares e económicas do porco na Antiguidade, ver I.O. CASTRO, "Para uma simbólica do consumo do porco e do javali na Antiguidade Tardia», 33-46. Sobre a abstenção de carnes por razões religiosas, ver Aptil., Met. 9.21, 23, 28, 30. Citações na pocsia, T(ond (1952) 93-94. Sobre o porco como animal purificador, como aparece na Oresteia, M. DiscoutrT, Oreste et Alcméon, Paris, 1959, 97-98.

${ }^{10}$ D.S. 34-35.3-4; ÁPION, apud J., Ap 2.137; EPICT., apud Arr., Epict. 1.11, 12-13; S.E., P. 3.223 (onde se afirma que um sacerdote judaico ou egípcio preferiria morrer a comer porco; que os Egípcios comungavam da ideia de que o porco era impuro, pode ser lido em Ho'T. 2.47); Ph., Legat. 361; Pl:Tr., frag. 37; J., Ap. 2.137, 14.1; Pl.t., Is. Os. 8; Quaest. Conu. 4.5.3; Tac., Hist. 5.4.1-4; ANax., apud ATh. 7, 2991-300a; Al:.., NA 10.16; Origlin., Cels. 5.34, 41. As associaçõcs ao Egipto são frequentes, como que um eco dessa relação histórica.

"Juv. 6.153-160. 
porcum esse quam filium) ${ }^{12}$ pois enquanto os porcos de Herodes morriam de velhice, alguns dos seus filhos não. Ainda relacionado com a dieta alimentar, o jejum foi outra das marcas reconhecidas aos judeus pelos não-judeus. Não tendo os dias de jejum escapado aos olhares dos Romanos, há alguns malentendidos entre os autores, concretamente em Suetónio, que afirma que Augusto terá pensado que também o Sábado era um dia de abstenção, confundindo o jejum com o Sétimo Dia ${ }^{13}$. Com a evolução dos acontecimentos, também a acusação de canibalismo, a forma mais eficaz de anatematizar o «Outro» e de exaltar o «Eu» como superior, cairá sobre os Judeus ${ }^{\text {". }}$

Também o repouso semanal era algo estranho aos olhos greco-romanos, visto que não temos conhecimento de que tal medida fosse adoptada por alguma outra cultura deste contexto, além de que corria o risco de ser visto como uma forma de otium sine dignitate ${ }^{1,5}$ O Sétimo Dia não deixa de ser uma marca omnipresente na caracterização dos Judeus, ainda que, como vimos, por vezes com ideias erradas associadas, como o jejum ${ }^{46}$. Outras parti-

${ }^{12}$ MACr. 2.4, 11. Diz-se que Augusto o afirmou quando soube da matança dos inocentes e que entre esses estaria o próprio filho de Herodes-o-Grande. Esta tradição tem óbvia influência do passo do Evangelho de Mateus referente ao massacre, que por sua vez poderá radicar nos processos políticos que levaram à condenação dos filhos do rei, por ordem do próprio pai.

"SulT., Aug. 76; LEON (1995) 24.5 estranha que um homem com "personal acquaintance with certain prominent Jews» cometesse tal erro. Parece-nos que a observação de Leon é parcial e que o facto de Augusto, ou Suetónio, ter feito tal confusão só pode significar pouca familiaridade e pouca importância prestada a tais personalidades ou que estas não seriam muito rigorosas nas práticas judaicas. De facto, há que distinguir as relações institucionais e políticas, que seriam amistosas, do nível de envolvimento pessoal do imperador com as comunidades judaicas de Roma. Ver ainda STr., Hist., apud J., AJ 14.66; Trog., Hist. 36, apud JisT. Epitome 2.14; MarT. 4.4,7 (onde se alude aos «hálitos de jejum dos sabatistas", SABbadini (1949) 5-8).

"O passo de D.C. 68.32, 1-2, relativo ao tempo de Trajano e Adriano e a uma sedição ocorrida em Cirene, é paradigmático: «Entretanto, os Judeus da região de Cirene puseram na sua liderança um tal André e começaram a eliminar tanto os Romanos como os Gregos. Terão comido a carne das suas vítimas, feito cintos para si com as entranhas delas, ungiram-se com o seu sangue e usaram as suas peles como roupa; a muitos, eles serraram em dois, da cabeça abaixo; a outros, lançaram aos animais selvagens, e a outros ainda obrigaram-nos a lutar como gladiadores. No total, terão perecido 220 mil pessoas.», e o Autor continua, afirmando que o mesmo tipo de situações ocorreu no Egipto.

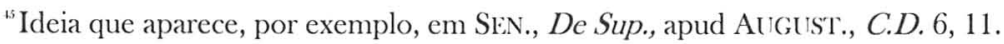

"Agatharch., apudJ., Ap 1.209-211; AJ 12.5; Tib. 1.3, 15-18; Hor., S. 1.9.63-72; Ov., Ars 1.76, 415; Rem. 217-220; Ápion, Aegyptiaca, apud J., Ap 2.21; Plin., Nat. 31.24; Tac., Hist. 5.4; Juv. 14.105-106, Plu., De Supers. 3; Goldinblerg (1979) 414-447; Michali. (1923- 
cularidades do Sábado encontram eco na literatura clássica, como a atraç̧ão que exercia sobre os não-judeus, por se tratar, precisamente, de um dia de descanso semanal, regular, desconhecido entre os outros ${ }^{17}$. Fílon conta que os judeus de Roma não aceitariam doações de dinheiro ou cereal (refere-se provavelmente aos congiaria) se a distribuição se fizesse ao Sábado ${ }^{18}$, pelo que as autoridades reservavam o quinhão dos judeus para o dia seguinte (informação que, por um lado, nos deixa crer que a condição económica de alguns judeus não era muito favorável e, por outro, que as autoridades romanas respeitavam, nessa época, as diferenças judaicas). Esta nota de Fílon, porém, sugere um paralelismo intencional com o passo do $\hat{E x o d o ~ e m ~ q u e ~ s e ~}$ conta que os judeus colhiam, à Sexta-Feira, maná suficiente para consumirem ao Sábado". Desse modo, a situação em Roma é equiparada à que se vivera pelos hebreus no deserto. Já Pérsio fala desdenhosamente da observação do Sábado $^{\text {50. }}$. Neste autor, há pormenores que nos elucidam quanto às práticas concretas do dia do descanso e é significativa a semelhança com a importância dada a motivos que virão a ser identificados com o cristianismo: o banquete, o peixe, o vinho. É também ao Sábado, mais concretamente ao «acender das lucernas» nesse dia, que se refere Séneca ${ }^{51}$. Em Juvenal, o assunto é tratado na sátira VI, onde, sarcasticamente, a propósito dos caprichos das mulheres, se diz:
Mense quidem brumae, cum iam mercator Iason
clausus et armatis opstat casa candida nautis,
grandia tolluntur crystallina, maxima rursus
myrrhina, deinde adamans notissimus et Beronices
in digito factus pretiosior: hunc dedit olim
barbarus incestae, dedit hunc Agrippa sorori,
obseruant ubi festa mero pede sabbata reges
et uetus indulget senibus clementia porcis.

1924.) 117-124; STr., Hist., apud J., AJ 14.66; STR. 16.2, 40; PETr., frag. 37; MarT. IV, 4; Sult., Aug. 76.2.

"J., Ap. 2.282; PH., Mos. 2.21, refere o orgulho que os Judeus sentiam por respeitarem esse dia.

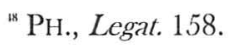

"Ex 16,22-27.

${ }^{50}$ PIiRS. 5.179-184.

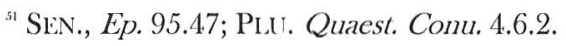


«Mas, no mês do Inverno, quando o mercador Jasão está fechado, e a tenda branca bloqueia os marinheiros armados, [ela] toma um grande [vaso] de cristal, e [um] ainda maior de mirra, e em seguida o famoso diamante valorizado pelo dedo de Berenice. Aquele que, um dia, o bárbaro deu à incestuosa, aquele que Agripa deu à irmà, no sítio em que os reis respeitam o Sábado de pés nus e onde uma clemência tradicional deixa os porcos morrerem de velhice.. ${ }^{32}$

Seria interessante relacionar a alusão ao anel de Berenice nas mãos de outra mulher com uma eventual evidência de que os Judeus vendem tudo, pois de outro modo, como teria o anel da princesa judia ido para as mãos de outrem? Mas falta-nos informação para concretizar essa ideia, que poderá não passar de um estereótipo.

Noutro passo, ressurgem os temas do Sábado e da dieta alimentar, e aparecem outros como o das imagens, o da circuncisão, o da avaliação do Direito judaico e o da existência de um «livro misterioso» que controla a sua vida:

Quidam sortiti metuentem sabbata patrem

nil praeter nubes et caeli numen adorant, nec distare putant humana carne suillam, qua pater abstinuit, mox et praeputia ponunt;

Romanas autem soliti contemnere leges

Iudaicum ediscunt et seruant ac metuunt ius, tradidit arcano quodcumque uolumine Moyses: non monstrare uias eadem nisi sacra colenti, quaesitum ad fontem solos deducere uerpos.

Sed pater in causa, cui septima quaeque fuit lux ignaua et partem uitae non attigit ullam.

"Alguns, tendo recebido em sorte un pai que teme o Sábado, nada adoram senão o poder das nuvens e do céu, e a carne humana não é para eles mais sagrada que a do porco, da qual o seu pai se absteve. Muito cedo, aliás, eles cortam o prepúcio e, acostumados a desdenhar das leis de Roma, não estudam, não observam e não temem senão todo esse Direito judaico transmitido por. Moisés num livro misterioso, refreiam-se de mostrar o caminho àqueles que têm um outro culto, apenas guiando na procura de uma fonte os que são circuncisos. Mas o responsável é o pai que deu à indolência e deixou inteiramente fora da vida um dia em cada setem."

Tendo como tema fundamental os maus exemplos e as consequências neles originárias, que os pais dão aos filhos, a sátira 14 de Juvenal, na qual se

\footnotetext{
${ }^{32}$ JiV. 6.153-160.

${ }^{53}$ Juv. 14.96-106.
} 
percebe uma síntese do que o «romano» sabe acerca do «judeu», pega nesta figura como um mau pai, quase por definição. No passo, subjaz a ideia de desrespeito pela lei romana, como uma conclusão retirada do facto de manterem as normas judaicas, expressas, por exemplo, na necessidade da circuncisão. Esta é uma perspectiva que coincide com a que encontramos em Tácito ${ }^{5 !}$.

O proselitismo acabou por ser uma consequência da atracção exercida por esta postura filosófico-religiosa sobre os não-judeus, e particularmente atraente quando incidiu sobre romanos. Díon Cássio testemunha que o nome «udeu» era igualmente aplicado a todo aquele que adoptasse os costumes dos judeus, salientando que essas pessoas existiam inclusive entre os Romanos ${ }^{53}$. As inscrições judaicas de Roma confirmam a existência de prosélitos e de $\theta \in o \sigma \in \beta \in i$ s/metuentes, que atestam a divulgação do judaísmo em Roma, mas que também definem os judeus da diáspora como um grupo não estanque e até como pólo de atracção cultural. Os celebrizados exemplos de Vetúria Paula (uma romana assumidamente prosélita) e da imperatriz Popeia Sabina são nisso paradigmáticos ${ }^{36}$. A literatura greco-latina não se refreia de os mencionar também, por vezes de uma forma neutra, outras de forma positiva ${ }^{37} \mathrm{e}$ outras ainda de uma forma satírica ou até mesmo de crítica mais profunda, dependendo da época a que a produção desses textos diz respeito. Horácio e Séneca são dos casos mais evidentes ${ }^{38}$. A legislação que Antonino Pio promulgará, na sequência do seu antecessor Adriano, já em meados do século II d.C., contra o proselitismo, deverá exprimir o êxito que a expansão do judá́smo alcançou na sociedade romana, designadamente entre as elites ${ }^{50}$. Segundo

${ }^{5+}$ TAC., Hist. 5.2-7.

${ }^{33}$ D.C. 37.17 .1 .

${ }^{36}$ Rodrigutis (2004) 136-14.5, 573-590.

${ }^{57}$ Estas aparecem maioritariamente em Josefo, que não perde a oportunidade de elogiar os Romanos que não se limitam a tolerar, mas a cultuar o seu Deus, como Sóssio, AJ14.488; cf. AJ20.195.

${ }^{3 x}$ Hor., S. 1.4.139-143; SEn., apud Auguist. C.D. 6,2; Ep. 95.47. Cf. TAC., Ann. 2.85 e o longo passo joséfico dedicado às conversões de Helena de Adiabene e seu filho, J., AJ 20.17 -96. O relato é uma longa digressão com que Josefo faz a apologia do judá́smo, reconhecido numa outra família real, sendo uma história com grandes semelhanças com a de José e seus irmãos. O problema da circuncisão é particularmente tratado (J., $A J$ 20.38-48) e a história salienta que o judaísmo traz a prosperidade ao reino de Adiabene. A visita de Helena de Adiabene a Jerusalém (que se teria realizado em $46-47$ d.C), e as riquezas que traz consigo, lembra a da rainha do Sabá ao reino de Salomão.

" Cf. Smaldwoon (1959) 334-34.7. Na verdade, Adriano proibiu de uma forma generalizada a circuncisão no Império, medida que afectou todos os que mantinham tal prática, 
Leon, a atitude destes dois imperadores em relação a esse ritual compreendese como uma tentativa de impedir a angariação de prosélitos, dado que isso implicava a circuncisão entre os indivíduos do sexo masculino, e não tanto a exterminação do judaísmo de Roma ${ }^{\text {in }}$. Mas sugere igualmente que o número de prosélitos deveria ser significativo, pois de outro modo não faria sentido tal proibição. É dessa mesma expansão que encontramos notícias em vários escritores gregos e romanos ${ }^{61}$. Há, porém, que ter a noção de que nem sempre esse fenómeno teve o mesmo impacte na comunidade não-judaica ${ }^{6_{2}}$ e, mais que o proselitismo em si, os Romanos pareciam preocupados com os prosélitos, precisamente aqueles que aderiam de facto ao judaísmo e que, portanto, entravam em ruptura com o equilíbrio da sociedade romana ${ }^{63}$. Posteriormente, Septímio Severo voltaria a legislar sobre circuncisos ${ }^{6 !}$.

Apesar de não ser uma exclusividade dos Judeus, ainda que ausente entre Gregos e Romanos, pois era conhecida fundamentalmente entre povos semíticos e camíticos, o costume da circuncisão era uma das suas principais marcas étnicas. O primeiro registo literário encontra-se no Génesis ${ }^{i 5}$, onde é tida como o sinal externo da aliança com Deus. Mas é provável que o costume remonte às origens comuns dos povos semíticos. Heródoto faz notar que os Egípcios e os Etíopes, representantes dos Camitas, também a praticavam ${ }^{66}$. Os Judeus são, todavia, por excelência os circuncisos da literatura greco-latina ${ }^{\text {in }}$. Se

independentemente de serem ou não Judeus. As razões para essa atitude não são bem conhecidas.

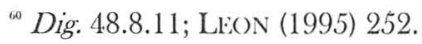

${ }^{61}$ V. MaX. 1.3.3; Hor., S. 1.4.138-143; Sen., De Sup., apud AuguisT., C.D. 6,11; TAC., Ann. 2.85.4; Sul:T., Tib. 36; D.C. 67.14.1-2.

${ }^{62}$ Ver M. Goodman (1994) 59 e Rutgers (1998) 208-209, onde se salienta que o fenómeno é mais incidente a partir do século I d.C.

${ }^{\text {ia }}$ Sobre esta questão, ver Will, OrRILux (1992) 106. Flididman (1993) defende a ideia de que, no mundo greco-romano, as massas detestavam o judaísmo enquanto as elites não, $\mathrm{e}$ que seria entre os membros deste grupo que se teria dado o maior número de conversões, nomeadamente no século I d.C., o que teria contribuído para o aumento da população judaica. Isso poderia explicar os medos da sociedade romana em relação ao judaísmo. A posição de Feldman, todavia, talvez seja também ela elitista, ao associar os intelectuais ao filo-judaísmo. Na verdade, como veremos infra, não faltam exemplos de intelectuais greco-latinos que se manifestaram anti-judaicos.

${ }^{6 t}$ Spartianis, Seucrus 17.1, apud $S H A$; Dig. 27.1.15.6; 50.2.3.3.

${ }^{15} G_{11} 17,9-14$.

${ }^{{ }^{66}}$ HDT. 2.104.2-3; Heródoto menciona igualmente os Colquídios.

${ }^{67}$ D.S. 1.28, 2-3; STR. 16.4 .9 (onde se referem mulheres que são ektetmemenai à maneira judaica); 17.2.5; Ápion, apud J. CA 2.137; Timag. 13.319; Hor., S. 1.9.63-72; Petr. 68.8; 
em alguns textos se trata tão-somente de assinalar uma marca física distintiva, noutros predispõe-se à formulação da sátira, como atestam Petrónio e Marcial $^{\text {is }}$. Seria essa a razão pela qual os Judeus seriam, popularmente, tidos como senhores de órgãos genitais desmesuradamente grandes ${ }^{69}$. A outra marca física identificada nos Judeus pelos autores greco-latinos diz respeito à forma como alguns deles penteavam o cabelo $^{70}$. Além destas, não há forma de perceber se os Judeus de Roma se distinguiriam dos Romanos em geral por outros aspectos fisicamente reconhecíveis.

A estes pontos juntam-se outros, menos universais, mas igualmente marcantes na caracterização do «Judeu» entre os Romanos. O tema da origem judaica, a que muitos dos autores greco-latinos recorrem para tentarem explicar as diferenças em relação ao seu referencial, é disso exemplo. É curioso que os textos clássicos pareçam nunca ignorar o Êxodo, tema-chave no tratamento dos Judeus ${ }^{71}$. Mas, enquanto a tradição judaica pretende que os Hebreus quiseram sair da opressão do Egipto, as fontes greco-latinas, do século III a.C. ao século II d.C., sugerem que foram os Egípcios a desejar a saída dos Hebreus. Assim, a ideia da expulsão, que nega a do desejo voluntário de sair, contradiz a imagem transmitida pelos textos judaicos. O motivo apontado como causa principal para essa saída é quase sempre a existência de uma epidemia de lepra, de que os Judeus eram portadores e propagadores ${ }^{72}$.

102.13-14; Plirs. 5.186; MarT. 7.30, 35, 82; 9.94. É possível que as comédias perdidas de Lívio Andronic(), Verpus, e de Névio, Apella, abordassem o tema da circuncisão, talvez até dos Judeus. A temática aparece igualmente em vários autores posteriores ao século II d.C. Cf. ZMIGRYDER-KONOPKA (1930-1931) 334-340.

“ PETR. 69.1-5. Também Marcial recorre a esse tópico, Ronkigites (2004) 734-739.

${ }^{69}$ Cf. Giordano), Kahn (1979) 62-63, onde uma estátua com essas características é interpretada como representando um judeu. Parece-nos, porém, que o pénis não se encontra representado como circuncidado, pelo que não deverá ser um judeu. Cf. o capítulo «A symbol of otherness: circumcision and salvation in the first century» de COLLINS (1997) 211-235.

${ }^{70}$ Um fragmento do romance de Petrónio alude aos nós atados na cabeça (caput nodatum), talvez os cabelos não cortados, por certo apanhados em nós, que depois deixavam cair, e que os Judeus mantinham em observação do preceito bíblico: "Não arredondareis as extremidades do cabelo». Cf. PETR., frag. 37; Lv 19,27; 21,5.

"Ver AZIZA (1980) 4.1-65.

${ }^{72}$ HeCAT. AlsD., Aegyptiaca, apud D.S. 34-35.1.1; 40.3.1-3 (onde Moisés aparece como herói fundador ao lado de Dánao e Cadmo); Man. Hist., apud J., Ap 1.73-91; Apolónio Mólon, apud J., Ap 2.148; Str. 16.2.35-36; Trog., Hist. 36, apud Just., Epitome 2.1-3; Lisimac., apud J., $A p$ 1.304-311; Apion, apud J., $A p$ 2.10; Chalrem. Hist., apud J., $A p$ 1.289292; TAC., Hist. 5.3-4. Cf. EX 4,6. 
Entre alguns intelectuais greco-latinos instalou-se também a ideia de que os Judeus eram originários do Egipto, o que é talvez consequência de uma má leitura ou transmissão dos textos bíblicos, especificamente dos episódios narrados no Génesis e no Exxodo ${ }^{73}$.

Além destes temas, que podemos considerar praticamente omnipresentes, surgem interpretações etiológicas e leituras várias que contribuem para a formulação da imagem do "Judeu», desde a acentuação da coragem de Moisés como cabeça do povo expulso, à identificação deste com uma mulher ${ }^{71}$, ao ateísmo, à misoxenia e à misantropia como características principais dos Judeus. Se por um lado o separatismo judaico contribuía para a criação de uma ideia de misoxenia e misantropia entre Gregos e Romanos, a falta de conhecimento correcto do que era o judaísmo e as suas práticas, como se parece deduzir de alguns dos textos citados, motivava igualmente o medo e a criação de efabulações em torno do povo e da sua religião, a qual poderia de algum modo subverter os mores romani. Entre essas ideias, podemos ainda citar as que fazem dos Judeus feiticeiros e magos, que recorrem a diversas poções em que usam ingredientes como a urina ${ }^{75}$; ou que os caracterizam como mendigos ${ }^{76}$; anómicos ou injustos ${ }^{77}$; misantropos ${ }^{78}$, associando-os a prostitutas e cultos estrangeiros ${ }^{79}$, cujo deus é denominado Iao ${ }^{80}$ e cuja religiosidade é primária e ingénua ${ }^{81}$; que se reúnem nas sinagogas e no Templo para conspirarem e para práticas desenfreadas e lascivas ${ }^{\mathrm{k}}$. Tópicos que contri-

${ }^{73}$ Gn 39-50; $E_{X}$ 1-15; D.S. 1.55.5; STR. 16.2.34-46; APION, apud J., Ap. 2.1-11.

"Allix. Polyh., apud Suda s.u. Alexandros o Milesios. Sugere-se, aliás, que tal mulher tenha vivido em Roma.

${ }^{75}$ Posidon., apud STr. 16.2.43; J., AJ 20.142 (onde se alude a Simão-o-Mago); Plin., Nat. 30.11 (Moisés como mágico); Lucianus, Trag. 173 (onde satiricamente se fala de alguém que, sofrendo de gota, e tendo tentado todos os remédios, recorre aos encantamentos de um judeu).

${ }^{76}$ MART. 12.57.13; Juv. 6.542-547; sch. Juv. 4.117 (onde se refere um homem qui ad portam Aricinam siue ad cliuum mendicaret inter Iudaeos, qui ad Ariciam transierant ex urbe missi, de onde alguns concluem que os judeus de Roma expulsos por Cláudio teriam ido assim para Arícia, uma localidade perto de Roma).

"D.S. 40.2, onde se alude à adikenı dos Judeus.

${ }^{7 *}$ TAC., Hist. 5; cf. TAC., Amln. 15.44, onde os cristãos recebem o mesmo tipo de tratamento.

"TaC., Ann. 2.85.

${ }^{\text {80 }}$ D.S. 1.94 .2 .

${ }^{\text {"1 }}$ Assim se entende do modo como Horácio se refere ao judeu Apela, Hor., S. 1.5.100.

${ }^{\text {*2 }}$ PH., Legat. 311-312; J., Ap. 1.149; cf. 2.91-93. 
buíram para a formulação da imagem do judeu, tal como a vamos encontrar na Europa sob a liderança espiritual da Roma cristã. As palavras do senador Marcelo, nos Acta Petri, em relação a Simão-o-Mago, um judeu, são disso já indicador: trata-se do pior e mais pestilento dos homens, corruptor da alma e da casa, que afasta de Jesus todo o fiel ${ }^{\$ 3}$. Apesar de cristã, é em território romano que a ideia germina.

Essa reacção compreende-se no quadro das expulsões e interdições de várias religiões orientais em diversos períodos da História de Roma. Recordemos que os Judeus são muitas vezes associados ao Egipto, inclusivamente em momentos de perseguição política. Talvez o conjunto destas razões explique também o motivo por que Josefo decide escrever as suas Antiquitates Iudaicae.

A construção da ideia de «udeu» entre os greco-romanos parece assim depender dos dados que dispõem sobre a História do povo, mas também sobre as tradições e cultura judaicas, os quais provêm de muitas fontes, que condicionam essa imagem. As referências aos Judeus dependem de motivações das conjunturas culturais e políticas, anti e filo-judaicas, o que se traduz nas várias posições que encontramos. A época e os condicionalismos em que foram escritas determinaram a sua natureza e esta premissa é fundamental para se perceber que lidamos com representações pré-determinadas. O nosso conhecimento deste facto histórico depende sempre de uma análise das motivações das fontes que a ele dizem respeito. Fílon é claro quando afirma que as autoridades do seu e de tempos anteriores sabiam alguma coisa sobre os judeus de Roma ${ }^{81}$, pelo que as deformações ou o tipo de tónica colocada nas informações têm um contexto, uma causa e um objectivo. Há que percebê-los. Mas desde já se adiante que a hostilidade depende de uma questão de ordem social e só recorre a argumentos como «etnia», «estatuto social» ou «estranheza» quando deles precisa para manter esse «cosmos».

Estas condições trazem ao de cima a problemática da identidade e da alteridade judaicas. Assim, parece predominar o esforço auto-separatista e exclusivista que encontra eco, fundamentalmente, no não-judeu, o que não significa, contudo, que o judeu não desejasse manter uma identidade própria, ainda que integrada. Derivam daí as críticas ao monoteísmo anicónico, as

\footnotetext{
${ }^{* 3}$ Acta Petri 14.

${ }^{81}$ PH., Legat. 155-157.

${ }^{*}$ SLivinstlir (1975).
} 
lucubrações em torno da onolatria, da misantropia, do canibalismo, da dieta e do jejum judaicos (em particular as reflexões sobre a abstenção da carne de porco, que se opõe à sua omnipresença na dieta greco-romana), do respeito pelo Sábado, do carácter prosélito do judaísmo, da circuncisão, da associação dos judeus a determinadas doenças (como a lepra), da acusação de ateísmo, de misoxenia e de feitiçaria. Tudo o que, virtualmente, tem a capacidade de subverter os mores romani e caracterizar a religião judaica como superstitio. Em causa está não tanto a estranheza relativamente a uma religião oriental ou sequer algum tipo de xenofobia étnica, como o facto de a cultura judaica assentar num conjunto de preceitos religiosos que se confundem com lei, de carácter exclusivista, esse sim, por vezes xenófobo em relação ao que vem de fora, por vezes até misantrópico, que anula todos os tipos de religiosidade que não sejam o seu. Os Romanos fizeram coincidir Júpiter, Zeus, Sabázio e Baal com Javé. Mas, na perspectiva judaica, toda e qualquer divindade é incompatível com Javé. Os princípios da exclusão, da rejeição e da incompatibilidade começam, pois, dentro da própria cultura judaica.

No contexto global do Império, a cidade de Roma parece ter um carácter específico, no que diz respeito à sua comunidade judaica. $\mathrm{Na}$ verdade, também essa realidade parece variar de região para região e não só de época para época. Em Roma, parece ter sido particularmente importante a ausência de uma facção grega politicamente hegemónica, como aconteceu noutros espaços e que levou a conflitos sérios com os judeus e a uma maior separatismo e isolamento destes. Alexandria parece ser o caso que mostra bem a diferença. Por outro lado, confirma-se também que, nesta comunidade da diáspora, se podia ser judeu por sangue e por religião, superando-se factores como a patria, a gens, a natio e a lingua, sendo essa uma realidade endógena e exogenamente reconhecida. É sobretudo o factor da comunidade de religião que impera. Mas, ainda que o judeu abandone a ortodoxia religiosa do seu povo, parece não deixar de ser considerado judeu. De qualquer modo, na maioria dos casos, a religião coincide com a origem étnica stricto sensu, e os dois factores formam as condições essenciais para que o Romano distinga o judeu como Outro e, pela diferença, ganhe consciência de si. 


\section{Bibliografia:}

C. AzIzA, "L' utilisation polémique du récit de l' Exode chez les écrivains alexandrins (IVème siècle av. J.-C.-Ier siècle ap. J.-C.)", ANRWII.20.1 (1980) 41-65.

J.J. Coluns, Secrs, Sibyls and Sages in Hellenistic-Roman Judaism (Leiden/New York/Köln, Brill, 1997).

L.H. Flidmman, Jew and Gentile in the Ancient World. Attitudes and interactions from Alexander to Justinian (Princeton, University Press, 1993).

N. Fick-Michli., Art et Mystique dans les Métamorphoses d'Apulée (Paris, Les «Belles Lettres», 1991).

J. Gatidemlt, "La condition juridique des Juifs dans les trois premiers siècles del'Empire», Augustinianum 28/1-2 (1988) 339-359.

C. Giordano, I. Kahn, Gli Ebrei a Pompei, Ercolano, Stabia e nelle cittì della Campania Felix (Napoli, Procaccini Editore, 1979).

R. Goldenibirg, "The Jewish Sabbath in the Roman World up to the Time of Constantine the Great", ANRWII.19.1 (1979) 4.14-447.

M. Goomman, Mission and Conversion. Proselyting in the Religious History of the Roman Empire (Oxford, Clarendon Press, 1994).

M. HARRIS, «Foodways: historical overview and theoretical prolegomenenon» in M. Harris; E.B. Ross (eds.), Food and Evolution: Toward a Theory of Human Food Habits, (Philadelphia, 1987) 59-60.

E.C. Klitus, "The Ass in the Cult of Dionysus as a Symbol of Toil and Suffering" in Painter and Poet in Ancient Greece. Iconography and the Literay Arts, (Stuttgart/Leipzig, B.G. Teubner, 1997) 411-70.

A.T. KRAABEI, "Jews in Imperial Rome. More Archaeological evidence from an Oxford collection", JJS 30-31 (1979) 41-58.

H.J. LEON, The Jews of Ancient Rome (updated edition, with a new introduction by C.A. Osiek, Peabody, Hendrickson Publishers, 1995).

J.H. Michali, "The jewish Sabbath in the Latin classical writers", AJSL 4.0 (1923-1924) 117 124.

D. Noy, Foreigners at Rome. Citizens and Strangers (London/Swansea, Duckworth/Classical Press of Wales, 2000).

A.M. Rablilio, "The Legal Condition of the Jews in the Roman Empire", ANRWII.13 (1980) 662-762.

S. Risinach, «Le culte de l'Âne» in Cultes, Mythes et Religions (Paris, Robert Laffont, 1996) 647-650.

N.S. Ronriguts, "Plutarco e o Judaísmo» in M. Jufresa, F. Mestre, P. Gómez, P. Gilabert (eds.), Plutarc a la seva època: Paideia i Societat. Actas del VIII Simposio Intemacional de la Sociedad Espanola de Plutarquistas. Barcelona 6-8 de Noviembre de 2003 
(Barcelona, Sociedad Española de Plutarquistas, Departament de Filologia Grega, Universitat de Barcelona, 2005) 431-438.

N.S. Ronrigulis, «Subtilezas orientais no Satyricon de Petrónio», Cadmo 14 (2004*) 77-95.

N.S. Ronriguts, Iudaei in VIbe. Os Judeus em Roma de Ponıpio aos Flávios (Lisboa, Diss. Doutoramento apresentada à Faculdade de Letras da Universidade de Lisboa, 2004).

L.V. RutgerRs, The Hidden Heritage of DiasporaJudaism (Leuven, Peeters, 1998).

S. Sabibadini, “"Ieiunia sabbatariarum”. Nota a Marziale, Ep. IV, 4,7», Annali Triestini IV/19 (1949) 5-8.

P. Schürler, Judeophobia. Attitudes toward the Jews in the Ancient World (Cambridge/London, Harvard University Press, 1997).

J.N. Sivvenster, The roots of pagan anti-semitism in the Ancient World (Leiden, E.J. Brill, 1975).

M.F. SilvA, "O Estrangeiro na Comédia Grega Antiga», Hunıanitas 51 (1999) $23-48$.

E.M. Smatrwo()D, "The legislation of Hadrian and Antoninus Pius against circumcision", Latonus 18 (1959) 334-347.

J. Soller, «Sémiotique de la nourriture dans la Bible», Annales. ESC 28/4 (1973) 943-955.

H. Solin, «Juden und Syrer im westlichen Teil der römischen Welt. Eine ethnisch-demographische Studiẹ mit besonderer Berücksichtigung der sprachlichen Zustände», ANRWII.29.2 (1983) 590-789.

O.J. TODD, «"Frustrum porcinum”», CPh 47 (1952) 93-94.

F.W. WAL.BANK, «Nationality as a Factor in Roman History», HSPh 76 (1972) 145-168.

B. WARDY, "Jewish Religion in Pagan Literature during the Late Republic and Early Empire», ANRWII.19.1 (1979) 594-644.

E. Will; C. Orrilitx, "Proselytisme Juif"? Histoire d'une emeur (Paris, Les Belles Lettres, 1992).

Z. ZMigryder-KonopKA, «Les Romains et la circoncision des Juils», Eos 33 (1930-1931) 334-34.0 . 


\title{
DACIA RIPENSIS, MOESIA SECUNDA ET SCYTHIA MINOR ENTRE LES CULTES PAÏENS ET LE CHRISTIANISME
}

\author{
Alaxandru Barnea \\ (Université de Bucarest)
}

En suivant les sources littéraires, épigraphiques et archéologiques, il est tout à fait évident que, dans les IVe-VIe s., la religion chrétienne devenait dominante dans ces provinces limitrophes de l'Empire aussi. Cette évolution a été très rapide, de la sorte que, au VIe s., les seuls édifices de culte en fonction dans le milieu provincial étaient les basiliques paléochrétiénnes, dont la présence a été remarquée dans presque tous les établissements fortifiées de l'époque et même en dehors de leures enceintes. En même temps, la généralisation des éléments de rite et de rituel spécifiques chrétiens ne laisse aucune place aux exceptions, dans la seconde moitié du IVe s. au plus tard. Voilà donc deux repères extrèmement importants et tout à fait concordants qui permettent de conclure que le christianisme s'était déjà imposé dans la région et, plus encore, ayant franchi les barrières socio-économiques, ethniques et politiques, dans une zone encore plus vaste que les limites géographiques conventionnelles (du limes y compris) des provinces danubiennes.

Sans plus insister, on va rappeler que, dans leur nouvelle forme, les provinces situées au Bas-Danube étaient le résultat des réformes administratives de la Tétrarchie instaurée par Dioclétien (284-305), procès commencé après l'ainsi dite retraite aurélienne des trois Dacies nord-danubiennes. C'est ainsi que vers la fin du IVe s. ap. J.C., sous les ordres du préfet de l'Ilyiricum se trouvait le diocèse de la Dacie dont les provinces situées sur le Danube étaient Moesia Prima et Dacia Ripensis et, sous les ordres du préfet de l'Orient, le 
diocèse de Thracia, dont les provinces danubiennes étaient Moesia Secunda et Scythia, résultat de la division de l'ancienne province Moesia Inferior (ND, Or., III, 4 sq. ; XXVI, 9 sq.). L'évolution de la politique religieuse impériale d'une part, et, de l'autre, la tradition générale et locale, ont contribué au maintien, pendant plus d'un demi-siècle encore, des croyances païnnes dans ces provinces. Les formes de la présence de celles-ci sont souvent assez suggestives pour pouvoir les mettre en évidence par des moyens couramment emlpoyés dans l'étude de l'antiquité, tels que textes littéraires et épigraphiques, témoignages artistiques, artisanaux etc.

Un premier exemple en est donné par une série de plus de 100 inscriptions grecques et latines (les dernières en majorité) identifiées des provinces Dacia Ripensis et Moesia Secunda, dont seulement une dizaine (six et respectivement quatre après SSIB et quelques publications ultérieures) contient des formules spécifiques païennes ou les textes q’elles contiennent sont susceptibles d'être considérés plutôt païens. Elles sont, toutes, limitées au IVe s. le plus tard et, pour ce qui est de leur destination, funéraires. Chacun de ces documents fut plusieures fois commenté, y compris du point de vue religieux, parce que, d'une manière ou de l'autre, ils offrent l'image d'un milieu qui hésite encore entre la tradition païenne et la tendance générale vers la nouvelle foi. Par exemple, le texte latin d'une inscription funéraire trouvée à Glava et datée au commencement du IVe s. (SSIB, 46 ; dép. de Vratza, Bulgarie ; Dacia Ripensis), exprime assez bien le commencement de ce processus : $T u$ uiator qui tr/ansis, rest(a), leg(e) titulum o/biter; le(ge) et rep(one). S(it) d(is) m(anibus) t(uis)/t(erra) l(euis). Val(erius) Tzita qui et Vi/ 5 /talis uet(eranus) et Florenti/us filius mil(es) et Vitalis/fill(ius) mil(es). Tzita pater/posuit Laurentzio/[f]ilio suo carissim/o]. Déjà C.M.Kaufmann remarquait et commentait l'utilisation de la formule païenne $D$ (is) M(anibus) dans premières inscriptions funéraires chrétiennes'. Dans le cas de Glava, la position de cette formule (toujours très bien connue par tradition et vue sa forme abréviée) à peine dans la troisième ligne de l'inscription au lieu de la première, est un signe encore plus clair du changement de croyance dans la famille du défunt. En tout cas, le père de celui-ci, Valerius Tzita, d'après son nom peut-être un Thrace romanisé et déjà chrétien, et, à ce qu'il paraît, d'accord avec lui, les autres trois personnages considéraient les Dieux Mânes comme ceux de Laurentzius

' C.M. Kaufmann, Handbuch der Altchristlichen Epigraphik, Freiburg im Bresgau, 1917, p.37 et 55 . 
('tuis). Par la suite, est-ce que le fils décédé aurait-il été un des derniers païens de la famille? Fort possible, bien que son nom, comme d'ailleurs celui de Florentius aussi, soit typique pour les chrétiens de l'époque?.

Plus proche de la tradition païenne est l'inscription de Flauius Victorinus, vétéran de la uexillatio II Scutariorum, mort à Odessos (SSIB, 130; aujourd'hui Varna, Bulgarie ; Moesia II) : Fl(auius Victorinus ue/tranus uixit annus $L$, mili(tauit)/an(nis) $X X V$ in uixillatione secon/ 5 /do Iscutariorom un R/ebicithrioen coniugen sua Antioci/an, qui ficit memuria titulum in eo./Vonas uias uiatur geras. Ce Flauius Victorinus avait fait peut-être son service militaire à Sacidaua (Dunareni, dép. de Constantza, Roumanie), ou même plus loin d'Odessos. Ce qu'on devrait y ajouter est le fait que le milieu militaire où notre vétéran avait vécu 25 années était plutôt paien, vue par exemple la dédicace qu'un de ses anciens collègues, lui aussi un vétéran, mettait à Capidaua (dép. de Constantza, Roumanie, prov. Scythia), pour Deus Sanctus Aeternus, il est vrai, d'une manière plutôt officielle (IGLR, 221). En revenant à l'inscription mise par Rebicithrio (une sorte de Rebecca) d'Antioche, aucun indice ne paraît permettre de lui attribuer un caractère chrétien ou cryptochrétien : on se trouve devant un des derniers documents latins privés - très important du point de vue de la langue aussi" - encore rattachés aux habitudes païennes.

En échange, l'inscription n 52 de SSIB (Hăršovo, dép. de Razgrad, Bulgarie ; Moesia Ih), datée toujours au IVe s., est moins claire pour ce qui est de la religion de la famille qu'elle représente: Fl(auius) Tethianus qandam/ circetor de nomero cata/fractariorum, ano/rum XXXVIII, decessit de/ 5 /umana uita et de/mil/si coinge. Non/nosal/Vapir et Fla/uio et Val/lerio /filios superstites (?)]. On ne connaît pas si la partie supérieure du document comprenait ou non pas la formule D.M. ; c'était fort possible. En tout cas, en reprenant l'étude de cette inscription après celle de V. Beševliev de 1964, V. Velkov la mettait dans la série des inscriptions païennes. Seule l'onomastique pourrait fournir quelque indice sur une tendance chrétienne

${ }^{2}$ I. Barnea, dans Studii Teologice, 2, 1954, 1-2, nº 29.

${ }^{3}$ Dans une unité détachée de Legio II Herculia; A. Aricesu, Armata în Dobrogea Romană, Bucarest, 1977, p.114-115; des détachements de scutarii se trouvaient en même temps aussi, toujours sul le limes du Bas-Danube, à Securisca, à 'Iatrus et à Appiaria, en Moesia II.

'H. Mihăescu, La romanité dans le S-E de l'Europe, Bucarest-Paris, 1993, passim.

${ }^{5}$ V. Velkov, dans Byzantinoslavica, 26, 1965, p.400. 
probable de la famille du défunt dont l'origine était plutôt de l'Asie Mineure (MPR, p.43-44).

Toujours de la Mésie Seconde, de Dineia (Vojvoda, Bulgarie), est connue une inscription funéraire remarquable pour ce qui est de son texte plutôt littéraire et en vers (SSIB, 74, IVe s.). Dépourvu de son commencement et de sa fin, le texte du document évoquant un naufrage ne laisse s'entrevoir qu'un seul élément religieux, dans la quatrième ligne du text gardé : l......fragillem Ipolstquam rate/m]//uelnerat ad portum uitata pericula cred/ens//lalmissam classem saepe in statione defl[ebat,//[in/cusansque deos talia est fortasse [locutus :J...(les vers continuent jusqu'à la $12^{\circ}$ ligne qui, à l'origine, n'était pas la dernière. Au premier regard, cette inscription est d'ailleurs moins importante pour l'évolution spirituelle de la population de la province, au moins parce que, à ce qu'il paraît, il s'agirait d'un personnage, Eusebius, apparenté à la famille impériale de la cour de Constance II. Or, si ce Eusèbe était un proche parent de l'impératrice Eusébie", "en laquelle Julien avait toujours eu un défenseur persuasif", alors, en remarquant aussi la forme plutôt traditionnelle et culte de l'épitaphe, le sens spirituel du document ne pourrait être autre que païen.

Sur plus de 300 inscriptions de la même époque identifiées dans la province de Scythie Mineure, à peine une vingtaine contient des formules ou dédicaces spécifiquement païennes". Parmi ces inscriptions, qu'elles soient votives ou funéraires, la plupart ne dépasse pas les premières décades du IVe s. On présente, dans les lignes suivantes, l'exemple d'une dédicace officielle trouvée à Tomis (auj. Constantza, Roumanie) et datant des années 285-292, adressée au Dieu Soleil dont le culte était déjà bien connu dans la région: Delol Soli pro [sal(ute)]/[im]p(eratorum) C(aesarum duorum) C(ai) Val(erii) Diocle/tiani]//et M(arci) Aur(elii) Maximiani//[inu/icti Aug(usti) trib(unicia) pot(estate) p(ii) f(elices)/5//iu/sso hac despositi/onel/[D(ominorum) N(ostrorum)] Aug(ustorum) porta/s siue $m$ ciuil//talti praesidalli siue riael//cur(ante)] C(aio) Aur(elio) F/irminianol u(iro) p(erfectissimo)/ /deuo/tissimo nlumini Aug(ustorum)/10//ciluitas [Tomitanorum fec(it)]. (IGLR, 3). Nous n'allons plus insister maintenant sur les autres problèmes que cette inscription ouvre par la confirmation de la séparation du pouvoir militaire de celui administratif

"J. Stroux, dans Hermes, 79, 1944, p.205-206.

'E. Stein, Histoire du Bas-Empire, I, Bruges, 1959, p.155.

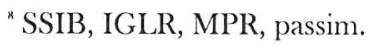


(dux et porta de la ciuitas praesidalis, donc de la ville fortifiée - siège du praeses) et par le déterminatif de la cité, praesidalis, qui suppose aussi l'existence d'une autre (ville ou plutôt partie de la ville, de même pour la porte). On connait d'ailleurs sur place, par voie archéologique, au moins deux portes de la ville de Tomis à l'époque du Bas-Empire. Pour en conclure, ce document confirme la présence de deux unités urbaines conforme à ladite séparation, en expliquant en même temps la présence dans les sources d'un nouveau nom de la ville (ou plutôt d'une partie de la ville) menant plus tard à celui hérité, à travers le Moyen Age, par le nom de Constanza d'aujourd'hui'. En revenant à la première ligne de l'inscription, rappelons que son contenu religieux est le résultat des circonstances bien connues pour tout le monde romain quand, vers la fin du Haut-Empire, le Dieu Soleil devait son ascension à la pénétration massive des cultes orientaux, en occupant très vite, avec des aspects syncrétiques aussi, une place de choix dans le panthéon officiel de l'Empire. C'était presque la même divinité qui, dans une dédicace que lui adressait un vétéran de Capidaua (dép. de Constantza, Roumanie ; prov. de Scythia), toujours au commencement du Bas-Empire, était appelée Deus Sanctus Aeternus, dieu dont l'origine était syrienne et pouvait être identifié aussi avec Sol,Jupiter et Apollo (IGLR, 221).

Un autre document épigraphique, sur une plaque en marbre ayant de l'autre côté une inscription funéraire plus ancienne en latin, est le dernier de ce genre jusqu'à présent dans la région, date des années 322-323 et comprend l'invocation du "Saint Dieu Soleil": Dei Sancti Solis / simulacrum consecr(atum) / die XIV kal(endis) Decemb(ribus) / debet singulis annis/ 5 /iusso sacro D(ominorum) N(ostrorum) / Licini Aug(usti) et Licini Caes(aris) / ture cereis et profu/sionibus eodem die / a praep(ositis) et uexillat(ionibus)/ 10 /in Cast(ris) Salsouiensib(us) / agentib(us) exorari. / Val(erius) Romulus u(ir) p(erfectissimus) dux / secutus iussionem / describsit. IGLR, 271 b, Salsouia, auj. Mahmudia, dép. de Tulcea, Roumanie). Selon ce document, le Dieu Soleil devait (n.s.) être imploré chaque 18 novembre, par le commandant militaire de la ville et par l'unité y campant, "avec de l'encens, des chandelles et des libations". On y voit, sans doute, quelques rituels repris un peu plus tard par les chrétiens dans leur pratique religieuse. Notre inscription était placée par le commandant de la province, Valerius Romulus, peut-être à la base

"Discussion plus ancienne et reprise avec la bibliographie antérieure par Al. Suceveanu, Al. Barnea, La Dobroudja Romaine, Bucarest, 1991, p.195-197. 
d'une image du dieu, "par l'ordre sacré de Licine Auguste et Licine César" et exprimait en fait la volonté de ceux-ci, envers leur propres troupes, dans un endroit important du limes de la province et de l'Empire. La forme du texte de cette inscription, plus que la première plus haut citée de Tomis (IGLR, 3) semble suggérer aussi, au-delà du dessein officiel, l'existence d'un milieu peutêtre hostile et qui devait (n.s.) se soumettre à l'ordre impérial, l'un des derniers émis par Licine. D'ailleurs, un autre document des mêmes années (peu avant le conflit entre les deux Augustes) a toujours un caractère officiel. Il s'agit d'un autel consacré à Iupiter Optimus Maximus et à Mars Conseruator, mis en l'honneur des empereurs Constantin et Licine (IGLR, 109, Histria, dép. de Constantza, Roumanie; prov. de Scythia). L'autel fait partie toujours des dédicaces officielles et provient probablement du même milieu militaire (v. plus haut), où l'habitude de l'adoration des divinités protectrices de l'armée s'opposait encore aux tendances chrétiennes de plus en plus fortes du même milieu. C'est dans ces conditions de l'évolution spirituelle que la plaque tombale d'un sous-officier de l'armée de Licine, le biarchus Valerius Victorinus, mort dans la célèbre bataille de Chacédoine (a. 324), portait toujours, dans la plus naturelle tradition classique, la dédicace, en train d'être abandonnée à l'époque, aux Dieux Mânes (IGLR, 206, Ulmetum, auj. Pantelimonul de Sus, dép. de Constantza; prov. de Scythia). Ajoutons que le relief de cette plaque, situé, selon toute une typologie de ces stèles, entre le fronton et l'inscription, comprenait, peut-être pour une des dernières fois dans la région, la scène de la héroïsation du défunt sous la forme du Cavalier ainsi dit Thrace ${ }^{10}$. C'est du même milieu militaire que provient un autel trouvé dans le territoire de Capidaua, dédié au même "Saint Dieu Herron", parce que l'auteur de l'inscription, cette fois-ci votive, était le commandant d'une unité de cavaliers (IGLR, 220).

Enfin, on rencontre dans les mêmes contrées, toujours au commencement du IVe s., des dédicaces à Hera Basilissa (autel avec l'inscription en grec), à Hercules Ripensis, à Iupiter Olbiopolitanus et à Poseidon Kyanochai-

164. tes (IGLR, 171, 172, 169 ; la dernière encore inédite et de nouveau en grec ; toutes les quatre de Tropaeum Traiani, auj. Adamclisi, dép. de Constantza,

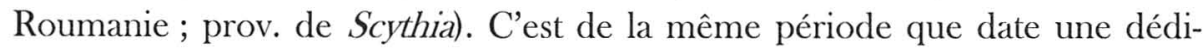
cace à Mater Deum Magna (IGLR, 2, Tomis). On y voit de nouveau apparâ̂tre (est-ce qu'il serait pour la dernière fois ?) cette divinité de souche orientale

${ }^{10} \mathrm{~V}$. notre dernière interprétation publiée sur ce sujet dans Asmosia, 5, Londres 2002, p.256-262. 
si répandue dorénavant, Cybèle, dont la dédicace avait comme auteur un des premiers commandants de la province de Scythie dite aussi Mineure : Matri deum / Magnae / pro salute adq(ue) / incolumitate/ 5 /D(ominorum) N(ostrorum duorum) et Caes(arum duorum) / Aur(elius) Firminianus / u(ir) p(erfectissimus) dux / limitis prou(inciae) Scyt(hiae) / bonis auspiciis/ 10 /consecrauit.

En suivant les documents épigraphiques et les résultats des recherches archéologiques, on peut constater que les pratiques païnnes ne semblent pas avoir trop dépassé la limite chronologique indiquée par les inscriptions sûrement datées dont on a parlé plus haut. Ce qui est même remarquable est le fait que, jusqu'à présent, de telles inscriptions n'apparaissent plus, au moins au titre officiel, après la date de la défaite de Licine par Constantin. De cette perspective à peine énoncée, vu le caractère plutôt officiel de ces documents, on peut y voir aussi des effets de la situation connue dans l'Empire en général. En tout cas, des offices de la sorte de ceux célébrés, sous la Tétrarchie, par des prêtres comme Maximus et Caius Crispus de la ville de Callatis, ne pouvaient pas cesser tout de suite (par exemple, après la mort de Licine). A Dinogetia (Garvăn, dép. de Tulcea, Roumanie; prov. de Scythia), fortification stratégique dans le système du limes danubien, la maison typique romaine du commandant (toujours l'armée!) ayant, au IVe s., à l'extrémité de N-E de l'atrium, un lararium, tout comme le fragment d'assiette en terre cuite y trouvée portant l'image imprimée d'Hercule et de Dionysos, reflètent encore une fois une continuité des cultes païens traditionnels au moins jusqu'à la moitié du IVe s." Et si une inscription funéraire d'Ulmetum (IGLR, 208) demandant : coeletes (sic !) Manes tures (sic !) avait été mise par un paganus, dont le lapicide changeait, au IVe s., le $t$ de ualeates, mot avec lequel l'inscription commençait, dans le signe d'une croix simple, on pourrait songer à une persistance des traditions païennes dans le milieu rural, en même temps avec la pénétration du message chrétien dans le même milieu. On y peut donc parler d'une résistance au christianisme qui a d'ailleurs conduit à la signification latine tardive du mot paganus, passé de là dans les autres langues ayant la même origine latine que le roumain, où il se retrouve avec le même sens que le français "païn" (en roumain "păgân")'. Enfin, en partant de la

\footnotetext{
" I. Barnea, dans SCIV, 20, 1969, 2, p.24.5-266 ; v. aussi p.257, n.13.

${ }^{12}$ H. Mihăescu, op.cit., § 26, 37, 145, 212 et passim. L'interprétation du paganus d'Ulmetum en tant que gladiateur (IGLR, p.220) ne résiste pas, à cause de la date tardive de
} 
même inscription, il convient de rappeler que les monuments funéraires restent les plus éloquents pour ce qui est de la persistance des coutumes païennes, puisque plusieurs inscriptions - sept connues en Scythie (IGLR 5, 17, 114, 168, 206, 208, 236) - étaient encore dédiées aux Dieux Mânes au début de l'époque du Bas-Empire. Il est vrai, sauf la stèle $n^{\circ} 17$, toutes les autres appartenaient aux personnages officiels, d'habitude de l'armée.

Un autre épitaphe, trouvé remployé parmi les marches menant de l'atrium vers le narthex des ruines de la grande basilique épiscopale de la ville d'Histria (VIe s.), est daté par l'auteur de la découverte au IVe s. et considéré comme cryptochrétien ${ }^{13}$. A la première vue, la lecture de l'inscription la place dans la série traditionnelle des stèles païennes: D(is) M(anibus) / Aur(elius) exuperat(us) / decurio ciuit(atis) / Hist(riae) uix(it) ann(is) $L / 5$ / relictis filiis. / Aure(Iia) Iouina / coniux benemere/nl/tit memoriam p/osuit./10/Vale uiator. Mais, comme notait son premier éditeur, dans le champ très usé de l'inscription, on distingue à peine un chrismon incisé à l'envers après la formule païenne $D M$, et, sous la dernière ligne, au milieu, l'image probable du poisson. Ajoutons d'ailleurs que la mise en oeuvre au VIe s. de cette plaque tombale dans la basilique avec l'inscription en haut (pas à l'envers comme d'habitude dans des situations archéologiques analogues, ou pas martelée, comme dans le cas plus bas évoqué de Sacidaua) pourrait se constituer dans un argument nouveau pour le caractère plus haut énoncé de ce document.

Ce qui se passait à l'époque sous les stèles ajoute des informations très importantes à la documentation épigraphique, dans les cas encore assez rares où les fouilles systématiques ont abouti aux résultats plus concluants. Premièrement et sans pouvoir encore généraliser, on peut remarquer dans le milieu provincial qui fait l'objet de cette étude de très importants changements dans la topographie funéraire. A la suite des recherches archéologiques des nécropoles de quelques villes et fortifications, on a constaté un déplacement de l'aire des tombeaux au Bas-Empire, en même temps avec l'abandon et la spoliation de la nécropole, sans doute païenne, de l'époque du Haut-Empire. C'est le cas plus clair du centre tardif de la nécropole de la ville de Callatis ${ }^{\text {"1 }}$ (auj. Mangalia, dép. Constantza, Roumanie; prov. Scythia) et de celle de Tomis, de Dinogetia et, à ce qu'il parait, de Tropaeum Traiani et de

l'inscription et aussi du lieu où elle fut trouvée. Ni le temps ni l'endroit n'étaient plus propices à de telles activités.

${ }^{13}$ Al. Suceveanu, dans Pontica, 31, 1998, p.114-117.

"C. Preda, Callatis. Necropola romano-bizantină, Bucarest, 1980. 
Capidaua, exemples auxquels il faut ajouter celui si éloquent de Sacidaua (auj. Muzait, près de Dunăreni, dép. de Constantza; prov. Scythia), dont la muraille d'enceinte était refaite à la même époque avec tant de plaques funéraires apportées de la nécropole romaine païenne ${ }^{15}$. Ce n'était plus seulement l'abandon, mais, plus que ça, la destruction presque systématique de l'ancienne nécropole aussi, accompagnée par le martelage des textes des stèles montées vers l'extérieur dans le parement de la muraille de l'enceinte. D'un autre côté, pour ce qui est de la structure des nécropoles en commençant avec la deuxième moitié du III e s., on constate que le milieu urbain renonçait de bonne heure aux rites et aux rituels païens d'enterrement. Par exemple, sur 367 tombeaux de la nécropole de basse époque romaine de la ville de Callatis, deux seulement, d'ailleurs les plus anciens (III e s.) n'avaient pas encore un caractère chrétien ${ }^{16}$. La situation en est à peu près pareille dans les autres nécropoles mieux connues, comme par exemple à Beroe (auj. Piatra Frecăței, comm. d’Ostrov, dép. de Tulcea, Roumanie ; prov. Scythia), où l'on a aussi constaté, fait particulièrement important, que le rite de l'inhumation était déjà généralisé à la fin du IIIe s. ap. J.C."

Parmi tous ces changements que les recherches archéologiques des nécropoles relèvent, celui concernant la topographie et plus haut évoqué vient d'être souligné aussi par une autre inscription tomitaine, déjà quelques fois commentée (ISM II, 372). ${ }^{18}$ Ce que Louis Robert notait à propos de cette stèle funéraire, "...l'épitaphe n'a rien de chrétien"19, était sans doute vrai.

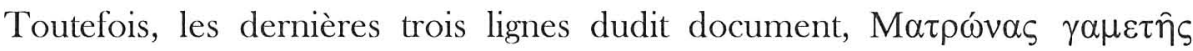

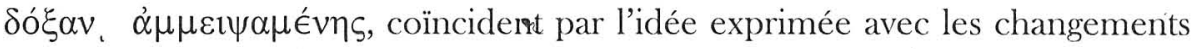
de l'endroit de l'enterrement constatés à la même époque, et c'est de ce point de vue qu'on peut de nouveau comprendre ce changement d'avis". Par la suite, la mère de cette famille ne s'enterrait plus dans le même endroit que les

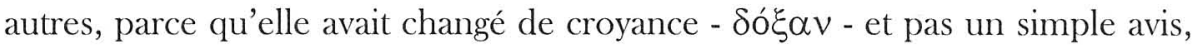
fait noté d'une manière assez précise par le lapicide.

${ }^{15}$ C. Scorpan, Limes Scythiae, BAR International Series, 88, Oxford, 1980, passim. Pour ce site et pour les autres plus haut évoqués, v. aussi Al. Suceveanu, Al. Barnea, op.cit., passim.

${ }^{16}$ C. Preda, op.cit., p.23-24.

1 A. Petre, La romanité en Scythie Mineure, Bucarest, 1987, p.89 (dans Bulletin de l'AIESEE, XVII-XVIII, 1987).

"Q Question reprise dernièrement avant notre article de 1995 par I. Barnea, dans Pontica, 24, 1991 (parue en 1993), p.269-270.

${ }^{19} \mathrm{~L}$. Robert, REG, 72, 1959, p.211, n 31 . 
On ne va plus insister dans ces lignes sur l'évolution plus ou moins connue du christianisme dans la région : persécutions, martyrs, les premières basiliques ou l'organisation de la nouvelle église etc. ${ }^{20}$ Dans les réalités historiques plus haut énoncées on retrouve le reflet de ladite évolution dans la société des provinces situées au Bas-Danube, qui pourrait être mieux éclaircie, au delà des aspects particuliers et des conclusions générales: comment les païens et les chrétiens vivaient et mourraient ensemble, avant que les premiers soient convaincus et vaincus par les derniers. C'est, par la suite, une direction de recherche dont l'esquisse l'auteur de ces lignes vient de présenter, dans l'espoir d'une meilleure documentation, plus riche et plus complexe, pour chaque province du Bas-Empire.

\section{Abréviations}

AIESEE $=$ Association des Etudes Sud-Est Européennes

IGLR $=$ Em. Popescu, Inscripțiile greceşti şi latine din secolele IV-XIII descoperite în România, Bucarest, 1976.

ISM, II = I. Stoian, Inscriptiones Scythiae Minoris, II, Tomis et territorium, bucarest, 1987.

MPR = I. Bamea, Les monuments paléochrétiens de Roumanie, Città del Vaticano, 1977.

ND, Or. = Notitia Dignitatum, Pars Orientis.

Pontica $=$ Pontica, revue du Musée d'Archéologie de Constantza, Roumanie, 1968 et suiv.

$\mathbf{R E G}=\quad$ Revue des Etudes Grecques.

SCIVA = Studii şi cercetări de istorie veche şi arheologie, Bucarest.

SSIB = V.Beševliev, Spätgriechische und spätlateinische Inschriften aus Bulgarien, Berlin, 1964.

${ }^{20}$ Pour la Scythie, v. MPR, passim ; nous avons repris ces problèmes avec la bibliographie antérieure dans La Dobroudja Romaine, l.c. et passim. 


\title{
AS VIAS DE COMUNICAÇÃO NA EUROPA ROMANA
}

\author{
Vasco Mantas \\ Universidade de Coimbra
}

O mundo contemporâneo é, em grande parte, resultado dos progressos verificados nos meios de comunicação, os quais, eliminando progressivamente as barreiras do espaço e do tempo tornaram possível o complexo fenómeno que designamos como globalização'. É indiscutível que, em nenhuma outra época da civilização, a não ser nos tempos da Roma imperial, as vias de comunicação tiveram igual importância e tão alargado uso como na actualidade. Com efeito, a extraordinária rede de comunicações terrestres, fluviais e marítimas que contribuíram de forma essencial para a constituição e unidade do Império, permaneceu sem paralelo até à Revolução Industrial, exercendo um impacte particularmente marcante no espírito dos homens que desde então ocuparam o mesmo cenário da História ou que com ele se identificaram, fossem letrados ou analfabetos. A mobilidade, hoje apresentada quase como uma novidade, foi, seguramente, uma das características fundamentais da civilização romana, quer do ponto de vista social, quer no tocante à deslocação de pessoas, bens e ideias. Não faltam testemunhos literários e arqueológicos desta mobilidade, ditada por razões tão diversificadas como as de hoje e em relação à qual soam estranhas as apreciações retóricas de alguns contemporâneos ${ }^{2}$. As vias de comunicação construídas ou organizadas pelos Romanos

' Sobre o seu discutido significado: M. Waters, Globalização, Lisboa, 1999. As ilustrações desta comunicação foram preparadas pelo Dr. Luís Madeira, a quem agradecemos cordialmente.

${ }^{2}$ Horácio, Epist., I, 11, 28. 
constituíram, para além de uma afirmação consciente de poder e de um reflexo evidente da capacidade de projecção de força do Estado romano, um elemento integrador de primeira importância”, transmitindo uma mensagem pragmática de ordem global, simultaneamente fautor e símbolo da maiestas romana.

O Império Romano foi um dos quatro impérios universais da Antiguidade, tão grande em extensão territorial como o nosso mundo ${ }^{4}$, o que permite compreender melhor o esforço realizado com o objectivo de criar vias de comunicação, primeiro na Itália e depois nas províncias, vias absolutamente necessárias ao bom funcionamento da administração e da economia, sem esquecer, naturalmente, os aspectos relacionados com a estratégia e a logística militares, razão primeira da sua concretização. A duração das viagens terrestres e marítimas que nos é dada a conhecer pelas fontes antigas é esclarecedora quanto às reais dimensões do mundo romano, verdadeiramente enorme. A este propósito recordamos apenas duas referências, aliás consideradas excepcionais pela rapidez registada, a deslocações entre a Itália e a Península Ibérica. Assim, César conduziu por terra um exército numeroso até ao Sul da Hispânia em vinte e sete dias, ultrapassando largamente o magnum iter indicado por Vegéció; Plínio-o-Velho aponta como muito rápida uma viagem marítima de sete dias entre Óstia e Cádis, pelo Estreito de Bonifácio ${ }^{6}$. Podemos comparar este último valor com a duração de uma viagem sem escala entre Lisboa e Luanda, nos anos sessenta, que era de dez dias.

Só tendo em conta comparações deste tipo podemos apreender a complexidade e o ritmo das comunicações num mundo pré-industrial onde o mensageiro de Maratona já não tinha grande significado, mundo que se estendia entre a Escócia e o Iraque, distância semelhante à que separava a fronteira oriental do Império do extremo ocidental da Muralha da China. Esta constatação parece-nos suficientemente elucidativa da ingente tarefa executada por Roma, sobretudo na época imperial, construindo estradas e portos e organizando uma estrutura administrativa que garantiu a eficaz operacionalidade do sistema e a sua vasta utilização por agentes oficiais e particulares. Parte impor-

${ }^{3}$ R. Laurence, Afterword. Travel and Empire, "Travel and Geography in the Roman Empire”, Londres, 2001, p.167-176.

' M. Rouche, Les empires universels, Paris, 1968, p.307; M. Grant, The Ancient Mediterranean, Nova Iorque, 1988, p.282-302.

${ }^{5}$ Apiano, Bel. Civ., XI, 15, 103 ; Vegécio, Epit., I, 9.

${ }^{6}$ Plínio, N. H., XIX, 3, 4. 
tante desta rede de comunicações situava-se em território europeu, onde Roma encontrou condições muito favoráveis à sua criação e ao estabelecimento de itinerários terrestres, fluviais e marítimos integrados. Todavia, não esqueçamos que o Império Romano não era constituído apenas por territórios exclusivamente europeus, factor que se reflecte claramente na atenção atribuída a outras regiões, em especial às de maior interesse estratégico ou económico fora da Europa, pelo que podemos considerar a rede de comunicações estabelecida, pelos Romanos, a partir da Itália e do Mediterrâneo, como intercontinental.

É quase dispensável apelar a exemplos do valor atribuído às grandes linhas de comunicação, instrumentos privilegiados da coesão imperial a todos os níveis, nas fontes escritas do mundo romano. Ainda assim, porque entendemos que o discurso do passado é fundamental para a sua correcta compreensão, sobretudo quando é possível combinar, como neste caso, os testemunhos literários com os testemunhos arqueológicos, tão abundantes e significativos, apresentamos aqui alguns. Escolhemo-los por transmitirem de forma muito clara como a existência de uma densa rede de estradas e de rotas marítimas de longo curso, organizada e policiada, permitiu desenvolver a ideia, essencial na política imperial, da pax romana, entendida como o maior contributo romano à diversificada comunidade de povos e culturas sob a sua hegemonia ${ }^{7}$.

Vejamos então um pequeno passo do que escreveu, por meados do século II, o filósofo Élio Aristides, um provincial da Ásia: Homero disse "terra comum para todos", e vós (romanos) tendes feito com que isso seja verdade. Percorrestes e registastes a terra de todo o mundo civilizado; estendestes sobre os rios todas as espécies de pontes e cortastes estradas através das montanhas, enchestes as estéreis áreas com postos de correio, habituastes todas as regiões a um determinado e ordeiro modo de vida. Não menos clara é a seguinte passagem do estóico Epicteto, também oriundo da Ásia Menor e escravo em Roma na época de Nero: César conquistou para nós uma paz profunda. Não há guerras, nem batalhas, nem ladrões, nem piratas, e podemos viajar a todas as horas e navegar de Oriente a Ocidente.

' M. Grant, O mundo de Roma, Lisboa, 1967, p.35-87 (= Grant, Roma); J. C. Barret, Romanization: a critical comment, "Dialogues in Roman Imperialism", Portsmouth, (RI), 1997, p.51-64.

"Élio Aristides, Or. Rom., XXXVI, 91.

'Arriano, Diss. Epict., III, 12, 9. 
Embora muito citados, estes dois testemunhos revelam-se particularmente elucidativos acerca das condições de mobilidade criadas pela administração imperial, tanto mais que reflectem a opinião de duas figuras não romanas, com visões de ordem social muito distintas, como é evidente, uma vez que Aristides representa a classe dos notáveis gregos orientais, defensores da hegemonia romana, enquanto Epicteto transmite um testemunho muito mais desinteressado, inserido num contexto em que, a par dos progressos da ordem e da civilização, se lembram os limites naturalmente impostos à condição humana $^{10}$. Viagens terrestres e viagens marítimas, sem limites e sem outros perigos que não fossem os decorrentes do acto de viajar, são considerados elementos fundamentais da convivência civilizada, válidos para o conjunto da população do Império, como se deduz do que aqui apresentámos dos textos de Aristides e de Epicteto, exemplo de um sentimento generalizado entre os contemporâneos.

Os autores antigos não se limitam, porém, a referir as vantagens oferecidas a nível das comunicações pelo domínio romano. De quando em quando, por vezes involuntariamente, aludem à fơłma como se viajava recorrendo a percursos de diferentes tipos para cumprir determinado itinerário, destacando assim um aspecto característico das grandes viagens no mundo romano. Tácito oferece-nos vários passos onde a estrutura da rede de comunicações do Império, entendida como um conjunto de vias terrestres e aquáticas inseridas num todo coerente e de fácil utilização, ressalta claramente. Eis dois exemplos relevantes: Pisão, depois de ter atravessado o mar da Dalmácia e deixado os seus navios em Ancona, ganha pelo Piceno a Via Flamínia, onde se junta a uma legião que faziam vir da Panónia a Roma para em seguida ser dirigida para uma guarnição em África". Noutro passo, o historiador romano põe em relevo a filosofia subjacente à concepção geoestratégica do Império, largamente dependente de um sistema de comunicações integrado, escrevendo: As fronteiras do Império eram no Oceano ou em rios distantes. Exércitos, províncias, esquadras, todo o sistema estava interligado ${ }^{12}$.

Os rios, mesmo quando fronteiras, caso do Reno e do Danúbio, foram intensamente navegados, completando ou facultando uma eficiente alternativa aos trajectos terrestres. Eram muito vulgares os percursos mistos, por razões

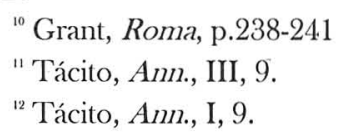


práticas, aproveitando as facilidades que as vias fluviais ofereciam à deslocação de passageiros e de mercadorias. Recorremos uma vez mais ao testemunho de um autor da época romana, neste caso Horácio, para ilustrar esta forma de viajar. Trata-se de um excerto da Viagem a Brindes, que levou o poeta de Roma à cidade adriática em 40 a.C., aquando das negociações entre os representantes de Octávio e os de António: Já o dia despontava quando sentimos que a barca não avançava uma linha. Um de nós, cabeça quente, salta em terra e castiga com um ramo tirado de um salgueiro a cabeça e os rins da mula e do barqueiro. À quarta hora, não antes, desembarcaram-nos finnalmente e lavámos a cara e as mãos na tua onda, ó Feronia! Em seguida, tendo almoçado, arrastámo-nos pelo espaço de três milhas e chegámos junto a Anxur (Terracina), assente em rochas brancas que brilham ao longe'.

Este texto de Horácio, para além do seu reconhecido valor literário, transmite uma ideia muito viva de como se viajava, sem ocultar o ambiente truculento que frequentemente rodeava as viagens, realçando a função de interface desempenhada pelas estações viárias situadas sobre cursos de água navegáveis. Este aspecto revelou-se especialmente importante no território europeu do Império, uma vez que são muito numerosos os rios navegáveis, podendo as pequenas embarcações atingir pontos muito a montante, como Estrabão refere a propósito dos rios da faixa ocidental da Península Ibérica" Os exemplos literários que apresentámos esclarecem da melhor forma a complexidade do sistema de comunicações romano, independentemente das distâncias a percorrer, provando que todos os transportes, terrestres, fluviais e marítimos, eram importantes e utilizados de forma pragmática, sendo copiosamente referidos pelas fontes escritas romanas ${ }^{15}$.

Como a nossa comunicação trata basicamente das vias de comunicação na Europa romana (Fig.1), consideraremos apenas esta área geográfica, sem esquecer que o território que lhe correspondia se aproximava bastante, com algumas excepções nórdicas, daquilo que Franz Altheim considerava em 1953 a Europa reduzida do pós-guerra, situando a Alemanha na sua fronteira Leste $^{16}$. Por outro lado, não é possível ignorar as grandes linhas intercontinen-

${ }^{13}$ Horácio, Sat., V.

"Estrabão, III, 3, 1-4.

${ }^{\text {is }}$ R. Chevallier, Les voies romaines, Paris, 1972, p.228-232 (= Chevallier, Voies) ; Voyages et déplacements dans I'Empire romain, Paris, 1988, p.7-15, 44.1-4.46 (= Chevallier, Voyages).

${ }^{16}$ F. Altheim, A Asia a caminho da Europa, Lisboa, s/d, p.14-17. 
tais de comunicação por via marítima, de particular importância económica e militar. Assim, estaremos a analisar somente uma parte do Império, o que pode obscurecer alguns aspectos relevantes da rede de comunicações imperial, pois não podemos ignorar que as diferentes regiões que o constituíam foram organizadas em função da Itália, antes de mais, e não da Europa propriamente dita.

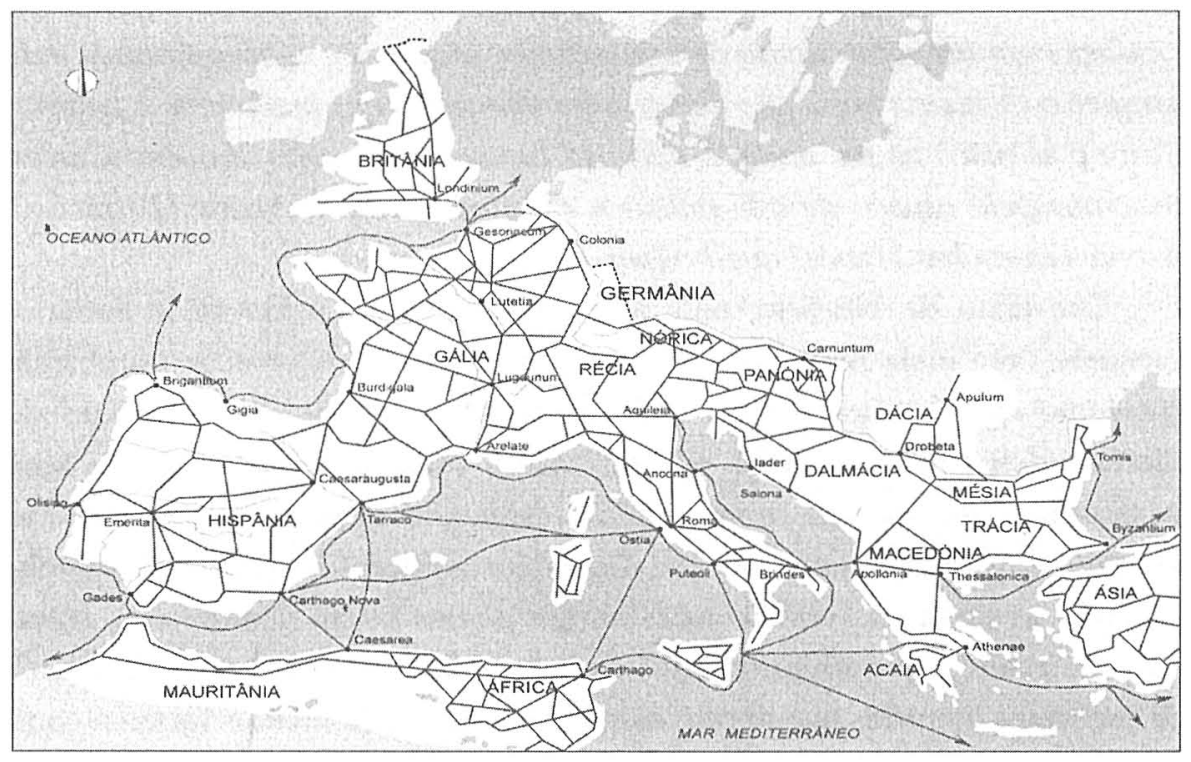

Fig. 1 - As principais vias de comunicação na Europa romana.

Esta questão dos limites da Europa é primordial, constituindo, hoje, um debate da maior actualidade e difícil apaziguamento. $\mathrm{Na}$ época romana a Europa era considerada uma das três partes que representavam o orbe habitado, embora a sua descrição geográfica nem sempre coincida nos autores antigos, sobretudo quando se trata de definir os seus confins para além do

174. Limes' ${ }^{\prime 7}$. Não nos devemos admirar da visão eurocêntrica que predomina nas fontes romanas, uma vez que aí se situava o centro do Império. A natural primazia da Europa é afirmada de forma lapidar por Plínio-o-Velho: Em primeiro lugar a Europa, nutriz do povo que conquistou todas as nações e, de

${ }^{17}$ Dúvidas que se reflectem, por exemplo, nos mapas de Agripa e de Ptolomeu: O. A. Dilke, Greek and Roman Maps, Baltimore, 1998, p.41-53, 75-86. 
longe, a mais bela das terras, correctamente considerada pela maioria dos autores não como um terço da terra mas metade, dividindo-a em duas partes, desde o Tánais (Don) até ao Estreito de Gades'.

O problema que se nos apresenta reside na definição da Europa como um espaço geográfico, de limites um tanto vagos na Antiguidade, sobretudo a norte e a leste, ou como um espaço cultural. A primeira destas opções prevaleceu na época romana, enquanto que presentemente parece desenhar-se a mesma tendência, declinando o conceito cultural, único garante da identidade europeia e do seu futuro como comunidade de destino, corroído pelos ditames de uma geometria variável, difícil de definir nos seus desígnios. Quer tudo isto dizer que, na Europa romana, as vias de comunicação são romanas, não europeias, organizadas num mundo centrado nas margens do rio Tibre, pelo menos até princípios do século IV. O mundo romano desenvolveu-se a partir do eixo mediterrâneo, integrando progressivamente regiões litorais, o que, até à conquista da Gália por Júlio César, que lhe conferiu a ocidente um factor de continentalidade, atribuiu ao território sob controlo romano uma acentuada feição arquipelágica". Posteriormente, a conclusão da conquista da região setentrional da Península Ibérica, por Augusto, e da Mauritânia e da Britânia sob o principado de Cláudio, criaram uma extensa fachada atlântica, facto que virá a revelar-se fundamental ${ }^{20}$. Não queremos defender uma atlantização do Império, o que seria exagerado, mas é evidente que a formação de uma extensa área atlântica sob domínio romano, com características profundamente diferentes das que constituíam o ambiente típico do mundo mediterrânico, deu lugar a uma dinâmica nova, igualmente sensível no capítulo das comunicações.

Por meados do século I, o Império Romano abre-se sobre dois mares, o Mediterrâneo e o Atlântico, sem esquecer o controlo que exercia rigorosamente sobre o Mar Vermelho, privilegiada via de acesso ao Índico ${ }^{21}$. Perante tal circunstância, pouco vulgar, não nos devemos admirar do facto de algumas das principais estradas romanas terem como ponto de destino ou de partida

${ }^{1 *}$ Plínio, N.H., III, 5.

"No início do século I a.C., ainda muitos dos mais importantes territórios da República só podiam ser alcançados por via marítima: K. Greene, The Archeology of the Roman Economy, Londres, 1986, p.12.

* V. Mantas, O Attântico e o Império Romano, "Revista Portuguesa de História", XXXVI, 2, 2002-2003, p.449-451.

${ }^{21}$ Chevallier, Voyages, p.353-357. 
centros portuários. A taxa de maritimidade do Império era, realmente, enorme, circunstância que condicionou desde muito cedo a sua estrutura de comunicações, atribuindo aos transportes por via marítima uma importância idêntica à dos transportes terrestres, suplantando-a mesmo, nalguns casos. Desta forma, não é possível continuar a considerar o Império Romano como um estado continental, porque o não era, mesmo se apenas tivermos em conta as áreas de maior profundidade territorial. Basta atentar na forma inteligente como foram utilizados os grandes rios gauleses para unir o Mediterrâneo e o Atlântico para o reconhecermos.

Roma tem sido vítima de preconceitos no que se refere à sua relação com o mar, vista por muitos como perfeitamente secundária. Esta ideia, ainda respeitada por conceituados historiadores, está muito longe de corresponder à realidade, não resistindo a uma análise geoestratégica, mesmo sumária, nem sequer a uma reflexão histórica que tenha em consideração os sucessos marítimos que pautaram o caminho para o império universal e sua manutenção ${ }^{22}$. A importância do mar como espaço de manobra e de poder fez-se sentir muito cedo em Roma, por influência directa dos seus vizinhos Etruscos e Gregos. Se as moedas da República arcaica ostentam uma figura bovina, de onde resultou o termo pecunia, muito rapidamente passaram a figurar uma proa de navio, enquanto se acomodavam ao padrão das moedas sicilianas e gregas. O século IV a.C. corresponde a um tempo decisivo da consolidação do poderio romano na Itália central, acompanhado do estabelecimento de uma rede de vias de comunicação terrestres e marítimas a partir daí em permanente expansão (Fig.2). A fundação do castrum de Óstia, a criação de dois grupos navais compostos de uma vintena de navios de guerra e a construção do primeiro troço da Via Appia mostram inequivocamente quais eram as intenções de Roma ${ }^{23}$.

Na Europa romana a construção de estradas e o estabelecimento de portos correspondeu inicialmente a razões de ordem militar e administrativa, mas o desenvolvimento de uma política de integração e de participação das provín-

${ }^{22}$ R. Buono-Core, La oceanopolitica y la geopolitica. Claves para una comprension del expansionismo romano entre los siglos VI e III a.C.?, "Semanas de Estudios Romanos", VIIVIII, Santiago do Chile, 1996, p.57-69; C. G. Starr, The Influence of Sea Power on Ancient History, Nova Iorque, 1989, p.67-81.

${ }^{23}$ R. Meiggs, Roman Ostia, Oxford, 1960, p.16-27; J. Heurgon, Rome et la Mediterranée occidentale jusqu' aux Guerres Puniques, Paris, 1980, p.289, 336-337; Chevallier, Voies, p.150-151. 
cia na vida do Império, que substituiu a feroz exploração da época republicana com excelentes resultados, transformou as funções das grandes vias de comunicação, conferindo-lhes novas atribuições, em especial no âmbito da economia. Tal como no conjunto do Império, a economia das províncias europeias organizava-se segundo três níveis, local, regional e imperial, o que ditava os meios de transporte e as vias a utilizar. Situaremos no primeiro destes

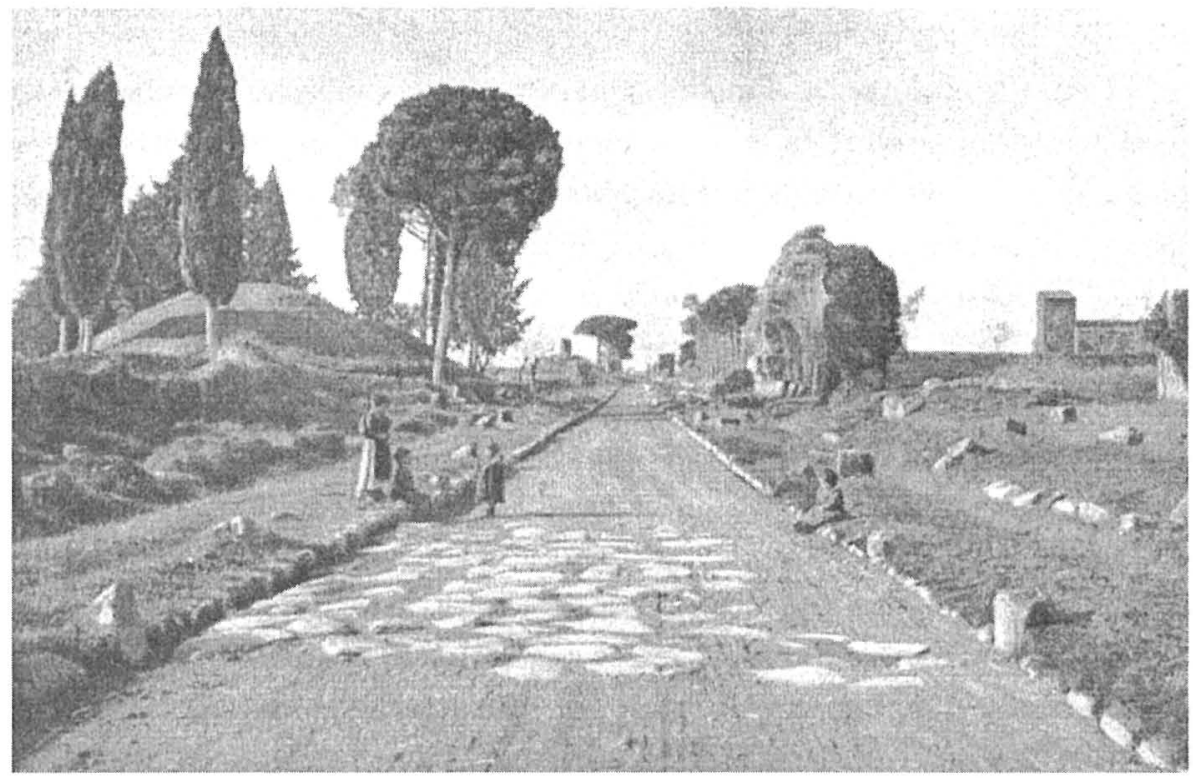

Fig. 2 - A Via Appia nos arredores de Roma nos finais do século XIX.

níveis as relações de vizinhança e as trocas comerciais de interesse local, numa área relativamente restrita, sem que possamos esquecer que certos produtos pouco interessantes por falta de transportes acessíveis, podem ser rentáveis num local cuja proximidade da estrada, do rio ou de um porto permita o seu fácil escoamento. No segundo nível tratamos já de um movimento de maior amplitude no espaço e no volume, considerando as longas deslocações de pessoas e de produtos no interior de uma província ou entre províncias. Recordamos, como exemplo, o transporte de produtos lusitanos para portos de reunião de cargas na Bética". Finalmente, o terceiro nível, o da economia à escala imperial, compreende o transporte de enormes quantidades de

${ }^{2}$ V. Mantas, Navegação, economia e relações interprovinciais. Lusitânia c Bética, "Humanitas", 50, 1998, p.210-214. 
produtos essenciais, de interesse estratégico, como o azeite da Bética e os cereais africanos para Itália, assim como os fornecimentos aos exércitos, por vezes estacionados em áreas de custoso acesso. Neste caso, como é óbvio, não se colocava o problema dos custos a suportar pelo Estado, uma vez que se trata de movimentos logísticos indispensáveis ${ }^{25}$. Também devemos situar neste nível o comércio dos produtos de luxo através do Império e para além das fronteiras, muito intenso e para o qual não faltam os testemunhos arqueológi$\cos ^{26}$.

Como é evidente, as funções administrativas e militares continuaram a pesar na estrutura da rede de comunicações, progressivamente mais densa e elaborada. A mobilidade de funcionários civis e de elementos militares conta com numerosíssima documentação. Em relação aos primeiros, recordamos apenas G. Iulius Celsus, cujo cursus honorum patente na inscrição conservada no Museu de S. Miguel de Odrinhas (Sintra) permite imaginar as longas deambulações deste importante funcionário imperial, que no século II ocupou cargos na Itália, na Narbonense, na Aquitânia, no Egipto, onde foi curador do Mausoléu de Alexandria, na Lusitânia e na Dácia ${ }^{27}$. Quanto aos aspectos militares $^{28}$, além dos reabastecimentos normais, remontas ou rotação de pessoal e dos grandes movimentos de tropas por razões operacionais, que exigiam, naturalmente, transportes maciços de todos os tipos e recorrendo a uma diversidade de meios, bem documentados nas fontes escritas e iconográficas (Fig.3), é necessário considerar, prioritariamente, a utilização estratégica dos meios de comunicação. Com efeito, com excepção da Britânia e das zonas fronteiriças, a presença militar era fraca ou inexistente na maior parte do território europeu, sendo esta debilidade do dispositivo compensada pela facilidade de deslocação das tropas de primeira intervenção. A Gália, por exemplo, contava somente com uma coorte aquartelada em Lugdunum (Lião), facilmente movimentada por via fluvial ou terrestre quando necessário ${ }^{29}$.

${ }^{25}$ J. Roth, The Logistics of the Roman Army at War (264 BC-AD 235), Leida, 1999.

${ }^{26}$ M. Wheeler, Rome beyond the Imperial Frontiers, Harmondsworth, 1955; F. Millar, Emperors, frontiers and foreign relations, 31 BC-AD 378, "Britannia", 13, 1982, p.1-23; Lin Ying, Ruler of the Treasury Country. The Image of the Roman Empire in Chinese Society fiom the First to the Fourth Century'AD, "Latomus", 63, 2, 2004, p.328-330.

${ }^{27}$ S. Lambrino, Les inscriptions de S. Miguel de Odrinhas, "Bulletin des Études Portugaises”, XVI, 1952, p.142-150.

${ }^{25}$ R. Davies, The supply of animals to the Roman army and the remount system, "Latomus", 28, 1969, p.429-4.59.

${ }^{2}$ Tácito, Ann., III, 40-42. 


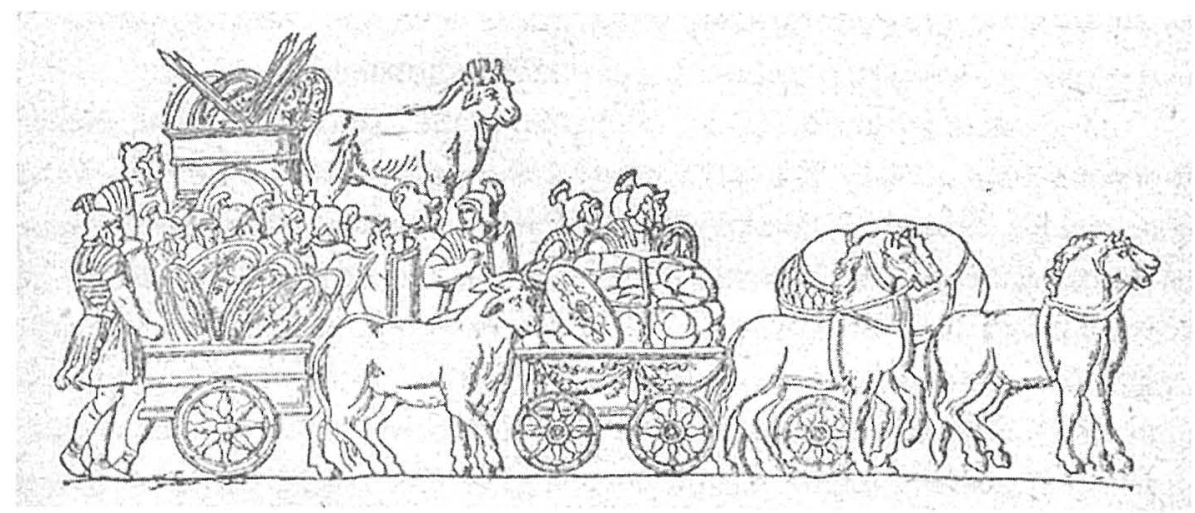

Fig. 3 - Um comboio militar figurado na coluna de Marco Aurélio, Roma.

O estabelecimento pelos Romanos de uma rede de estradas na Europa, eficazmente secundadas pelo transporte fluvial e marítimo, teve antecedentes nem sempre devidamente considerados. Na Itália, a civilização etrusca conheceu a construção de estradas, que incluíam já obras-de-arte significativas, facultando o que parece ter sido a tecnologia básica utilizada nas vias romanas. Nalguns locais, identificaram-se restos de estradas etruscas, como em Narce, onde se escavou um troço de via romana construído directamente sobre o caminho etrusco $^{30}$, facto que chama a atenção para a necessidade de identificar os traçados viários anteriores, que com frequência serviram de condutores às estradas romanas e que explicam certas peculiaridades dos seus traçados. $\mathrm{Na}$ verdade, em muitas regiões da Europa ocidental, as estradas romanas sucederam a caminhos indígenas, frustes, é certo, mas que existiam. Frequentemente, o que a administração romana fez foi renovar esses caminhos e integrá-los em itinerários extensos e coerentes, ao serviço dos interesses romanos, militares, administrativos e económicos. Assim, a estrada entre Olisipo (Lisboa) e Bracara (Braga), foi estabelecida em grande parte sobre caminhos indígenas, como os tesouros monetários do período republicano demonstram, o mesmo acontecendo com a estrada que, tocando o litoral, unia o Tejo e o Mondego". Na Gália, o caminho que se desenvolvia do Mediterrâneo até ao Atlântico, de Narbo Martius (Narbonne) a Burdigala (Bordéus), por Tolosa (Toulouse),

${ }^{30}$ T. Potter, The Changing Landscape of South Etruria, Londres, 1979, p.107-108.

" J. Ruivo, O conflito sertoriano no Ocidente hispânico: o testemunho dos tesouros monetários, "Archivo Español de Arqueología”, 70, 1997, p.91-100. 
seguindo o Garona, corresponde a um grande caminho comercial indígena, percorrido de ocidente para oriente pelo estanho britânico ${ }^{32}$.

Não é necessário multiplicar exemplos de uma situação normal, pois os Romanos não podiam ignorar a existência desses caminhos, muitas vezes relacionados com eixos comerciais importantes, progressivamente integrados na esfera da economia romana, tanto mais que alguns deles, como a Via Heraclea, na Península Ibérica, gozavam de mítico renome ${ }^{33}$. A transformação destes caminhos, de que a toponímia conservou, algumas vezes, a memória, numa autêntica rede de comunicações, só foi possível, como se compreende, depois do estabelecimento da unidade política, sem a qual não teria havido condições nem meios financeiros para concretizar uma obra de tal envergadura. Na verdade, foi assim que se criou, a partir da diversidade, a primeira unidade da Europa.

Neste cenário, as ligações com o mundo nórdico, para além dos Alpes e com a área atlântica revelaram-se da maior importância desde muito cedo, pela facilidade de colocar produtos mediterrânicos, como o vinho, e aí obter, directa ou indirectamente, os metais de que as civilizações urbanas do Sul não dispunham, nomeadamente o estanho, cujo valor se mantém na Idade do Ferro $^{31}$. Os Alpes constituíram sempre uma dura barreira e simultaneamente uma área de passagem, atravessada por vales controlados pelos indígenas, comunicando o interior do continente com o Mediterrâneo ${ }^{a j}$. A importância económica e estratégica destas passagens era, e é, enorme. A invasão da Itália por Aníbal, na Segunda Guerra Púnica, ilustra perfeitamente o valor dos passos alpinos, que serão um dos primeiros objectivos de Augusto na redução das áreas não controladas no interior do Império ${ }^{96}$.

O avanço do domínio romano incorporou na rede de comunicações republicana e imperial rotas marítimas com um longo historial, servindo interesses específicos deste ou daquele povo, muitas vezes razão para antagonismos violentos, como o que opôs com tanta frequência Fenícios e Gregos.

${ }^{32}$ Chevallier, Voies, p.4-5.

${ }^{37} \mathrm{R}$. Dion, La voie heracléenne et l'itinéraire transalpin d'Hannibal, "Hommage A. Grenier", I, Bruxelas, 1962, p.537-543; Chevallier, Voyages, p.19-20.

${ }^{3}$ A utilização do bronze no Império Romano não foi, quantitativamente, inferior à que se verificou em épocas anteriores, pelo que o fornecimento regular e abundante de estanho permaneceu uma necessidade: Greene, p.143-144.

${ }^{35}$ Chevallier, Voies, p.188-194.

${ }^{3 i}$ P. Petit, La paix romaine, Paris, 1967, p.108-109, 392. 
A expansão romana na Itália levou, sobretudo depois da conquista das colónias gregas, a que este tipo de conflitos ganhasse particular relevo na política romana, como não podia deixar de suceder, dele resultando a Primeira Guerra Púnica. Desta forma, as rotas comerciais da Antiguidade foram transferidas para a gestão romana e integradas num sistema homogéneo que, permitindo alguma autonomia e vantagens seguras aos seus anteriores utilizadores, respondia em primeiro lugar às necessidades do mundo romano. Assim sucedeu na Península Ibérica em relação ao comércio marítimo atlântico controlado por Gades, cujo foedus assinado com Roma em 206 a.C. permitiu a esta assumir a sua direcção e aos gaditanos preservar os seus interesses económicos ${ }^{37}$. Mais a norte, o comércio entre a Gália e a Britânia estimulou muito rapidamente a atenção romana pelo que era um espaço económico coerente, levando à ocupação da ilha, precedida por uma forte presença de comerciantes romanos, e consequentemente à manutenção das ligações tradicionais existentes e sua participação numa rota de longo curso circum-navegando a Gália e a Hispânia, herdeira da que a Ora Maritima obscuramente descreveu $^{38}$. Mais uma vez o domínio romano promoveu o desenvolvimento de alguma coisa antes considerada excepcional e aventurosa, como era a navegação entre o Mediterrâneo e o Canal da Mancha, numa actividade regular, reconhecida como normal pelos autores da época.

As fontes disponíveis para o estudo das comunicações no mundo romano dividem-se em dois grandes grupos, quantitativamente desiguais. $\mathrm{Na}$ verdade, enquanto as fontes arqueológicas são copiosas e muito variadas, as fontes puramente literárias são escassas, mesmo em relação à rede viária, circunstância que pode parecer inesperada quando é conhecida a importância que os Romanos atribuíam aos transportes e comunicações. Para as vias terrestres, a falta de textos literários é compensada pela ubiquidade dos seus vestígios materiais (Fig.4), mesmo na Europa, onde os Humanistas desde muito cedo os tomaram como referência obrigatória de um discurso em que o passado romano é apresentado aos contemporâneos como sugestão de eficiência e símbolo de um ideal de unidade. Recordemos o que Francisco de Holanda

${ }^{37}$ J. Rodríguez Neila, El municipio romano de Gades, Cádiz, 1980, p.25-34; G. Chic, Roma y el mar: del Mediterraneo al Attántico, "Guerras, Exploraciones y Navegación del Mundo Antiguo a la Edad Moderna”, Corunha, 1995, p.60-62.

${ }^{3 *}$ B. Cunliffe, Facing the Ocean. The Atlantic and its Peoples, Oxford, 2001, p.384-407; Avieno, Orla Marítima (Introdução, tradução e notas de J. R. Ferreira), Coimbra, 1992", p.19-37. 
escreveu a propósito da estrada que de Lisboa ia a Roma: E não pudera eu crer esta coisa se quando parti de Lisboa indo a Roma, logo em Sacavém não achara a via romana e a ponte quebrada no Rio, e nas charnecas de Montargil, ali onde chamam as Mestas, as calçadas de scilice, e em Castela nos barcos d'Alconete e na antigualha de Capara, e depois em Aragão, Lérida e Catalu-

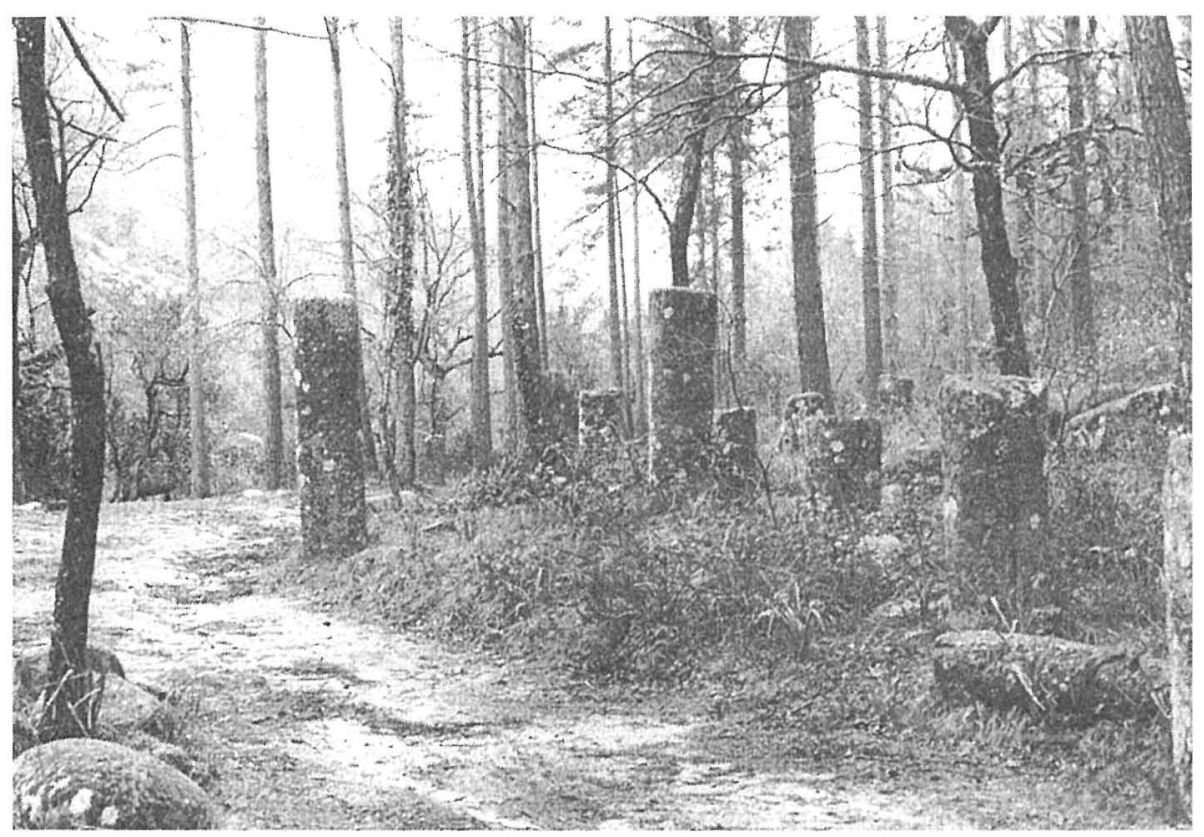

Fig. 4. - Um "ninho de miliários" na Estrada da Geira (Portela do Homem).

nha; e depois em França na cidade de Nîmes, onde está o famosíssimo anfiteatro e memórias dos antigos; e depois em o foro de Júlio em Provença e em Antibo e nos Alpes e porto de Ligúria e Toscana, sempre achando a mesma calçada que achei saindo de Lisboa até entrar em Roma ${ }^{30}$.

182 Esta justificada admiração pela grandiosidade da obra romana, sustentada ora em ruínas imponentes, ora em obscuros remanescentes, teve como consequência a multiplicação, um pouco por toda a Europa, de calçadas e pontes consideradas romanas e, pela mesma razão, levou ao aparecimento de numerosas imitações a partir da Idade Moderna, circunstância que difículta o estudo

${ }^{39}$ Francisco de Holanda, Da fábrica que falece à cidade de Lisboa (Introduçào, notas e comentários de J. F. Alves), Lisboa, 1984, p.27-28. 
sistemático deste tipo de testemunhos arqueológicos. Muito menos numerosos, os restos visíveis de instalações portuárias, marítimas ou fluviais, apenas estimularam modestamente a imaginação, tanto mais que só no século passado se tornou possível estudar cientificamente a maior parte deles, nomeadamente os que se encontram submersos ${ }^{\text {ti }}$. Este desfasamento quantitativo entre vestígios viários e portuários, muito acentuado, também contribuiu para que se espalhasse a falsa ideia da pouca importância das comunicações não terrestres, ainda vulgar apesar dos notáveis avanços no conhecimento das actividades marítimas e fluviais na Europa romana verificados nas últimas décadas.

Não nos devemos admirar, todavia, da falta de escritos técnicos sobre a construção de estradas, que parece corresponder a uma característica própria da mentalidade romana, mais interessada noutro tipo de questões, como prova a relativa abundância de referências jurídicas à construção de vias, sua hierarquia e utilização, pública ou privada ${ }^{41}$. A diversidade na construção de caminhos foi já amplamente demonstrada pelos arqueólogos; outra coisa não seria de esperar, pelo que a teimosia em respeitar um modelo de via romana baseado na errada interpretação de Nicolas Bergier não tem qualquer razão, limitando-se a um infeliz e incómodo lugar comum, que os dados arqueológicos obrigam a eliminar, tão grande é a variedade de estruturas registada ${ }^{42}$. Esta diferença resulta quer da categoria e funções da estrada, quer da forma como a sua construção era dirigida e executada. Sem ignorar a importância da participação dos militares na abertura de estradas, também é certo que muitos trabalhos foram adjudicados a empreiteiros civis, frequentemente contratados pelas autoridades locais, o que não deixou de provocar problemas, quer de peculato, quer de má construção, idênticos aos que Cícero refere no Pro Fonteio a propósito da renovação da Via Domitia na Provença ${ }^{13}$.

\footnotetext{
"V. Mantas, Portos marítimos romanos, "Memórias da Academia de Marinha", (VIII), 2000, p.14-24.

"Podemos considerar viae pủblicae, viae vicinales e viae privatae. Quanto à construção, os textos jurídicos referem viae lapidae stratae, viae glareae stratae e viae terrenae: Siculus Flaccus, De conditionibus agrorum, (Ed. C. Thulin), I, Lípsia, 1913, p.110,1; Ulpiano, Dig., XLIII, 11. É particularmente importante a legislação viária produzida na época imperial: C. Pharr, The Theodosian Code and Novels and the Sirmondian Constitution, Princeton, 1952.

${ }^{12}$ N. Bergier, Histoire des grands chemins de I'Empire Romain, I, Bruxelas, 1728², p.151; Chevallier, Voics, p.93-95.

${ }^{13}$ Cícero, Pro Font., VIII, 17.
} 
Outro aspecto que deve ser considerado quando se estuda a rede de comunicações do Império Romano no território europeu é o do elevadíssimo custo de construção de uma estrada ou de um porto artificial, a que era preciso adicionar despesas regulares de manutenção, nem sempre observada de forma conveniente. No caso das grandes vias públicas ou militares, que deveriam permitir a circulação em qualquer estação do ano, desde logo ao cursus publicus, a sua construção em determinadas regiões teve em consideração a necessidade de atravessar zonas alagadiças ou sujeitas a nevões intensos, encarecendo ainda mais obras já de si dispendiosas. Não faltam informações sobre esta delicada questão do custo das vias de comunicação, sobretudo na epigrafia e na literatura histórica. Assim, sabemos que, na Itália, o imperador Adriano e personagens privadas se associaram para executar beneficiações num troço de cerca de 16 quilómetros da Via Appia (CIL IX 6075), podendo o custo de construção de uma nova estrada alcançar um valor igual ao do edifício mais caro de que temos conhecimento no mesmo período, as Termas de Neptuno, edificadas por Antonino Pio em Óstia". É evidente que os custos de construção nas províncias nem sempre eram tão elevados, o que não significa que fossem desprezíveis. Na Hispânia, uma epígrafe de Oreto recorda que o evergeta local P. Baebius Venestus gastou com a construção de uma ponte 80000 sestércios (CIL II 3231=6339=ILER 2067), enquanto que na cidade de Ercavica um tal C. Iulius Celsus dispendeu 100000 sestércios na construção de 8 milhas de via ${ }^{15}$, importância que mal daria para uma única milha da Via Appia. Os vultuosos investimentos que a administração romana devia atribuir à construção e manutenção da enorme rede viária do Império levaram a que se procurasse sistematicamente o apoio dos particulares e das cidades nesse esforço financeiro, o que nem sempre sucedia. Suetónio conta-nos um episódio esclarecedor acontecido no tempo de Tibério: Outra vez pediu que os habitantes de Trébia fossem autorizados a consagrar à abertura de uma estrada a importância que the tinham legado para construir um novo teatro, mas não o conseguiu e a vontade do testador foi ratificada ". mas na oconseguiu e a voltade do testador foi ratificada".

"Th. Pekary, Untersuchungen zu den Römischen Reichsstrassen, Bona, 1968, p.93-95; R. Duncan-Jones, The Economy of the Roman Empire. Quantitative Studies, Cambridge, 1974, p.124-125, 157-160.

"G. Alfoldy, Römisches Stadtwesen auf der Neukastilischen Hochebene, Heidelberga, 1987, p.70-74.

"Suetónio, Tib., XXXI, 2. 
Parece poder deduzir-se que, embora a intervenção de mecenas locais tenha contribuído para atenuar as dificuldades da administração, sobretudo na época imperial, quando a rede viária se tornou enorme ao mesmo tempo que muitos dos itinerários perdiam importância estratégica, a verdade é que não resolvia o problema, obrigando muitas vezes à intervenção imperial ou, não havendo alternativa, ditando a má qualidade de muitas estradas, mesmo importantes e não apenas nas províncias. Por isso mesmo não nos devemos admirar da insistência imperial em conferir aos notáveis e às cidades, evidente na legisłação do Baixo Império, a obrigação de construir e manter a rede viária, o que explica a transferência das doações cívicas urbanas, como uma nova forma de celebração política, para a execução de trabalhos viários ${ }^{17}$. É possível que algumas das crises que atingiram certas regiōes de recente urbanização do Império, se possam relacionar com a realização de obras em larga escala na rede de estradas, por iniciativa de centros urbanos então envolvidos num processo de afirmação jurídica, a qual não terá conduzido somente à construção de conjuntos monumentais, tanto mais que no Alto Império não era fácil obter autorização para aumentar os impostos locais. Finalmente, recordamos que, para além de todas as dificuldades e em parte por isso mesmo, foi sempre um acto político prestigioso construir ou reparar estradas e, por isso, os magistrados que desempenharam funções relacionadas com a rede viária, eram particularmente honrados (Fig.5).

O mesmo podemos dizer da construção ou renovação de grandes portos, em especial dos portos artificiais construídos na época imperial. Parte importante dessas instalações portuárias respondia a necessidades muito concretas do abastecimento da cidade de Roma e da Itália, assim como dos efectivos estacionados nas zonas fronteiriças, pelo que estes portos se tornaram elementos fundamentais da política imperial. Assim como a Ápia constituía o símbolo máximo da rede viária, o complexo portuário de Óstia, sucessivamente alargado e melhorado, representava o enorme esforço desenvolvido para dotar Roma de um porto eficiente, directa e rapidamente ligado à capital pelo Tibre e por estrada (Fig.6), tanto como uma afirmação de triunfo sobre a natureza e da maiestas imperial. As moedas de Nero e de Trajano, comemorando o fim dos difíceis trabalhos de construção do Portus Augusti empreendidos por

"O encargo com a reparação de estradas tornou-se uma obrigação institucionalizada, a suportar pelas cidades, o que explica os numerosos miliários em dativo do Baixo Império: Cod. Theod., XV, 3 (De itinere muniendo). 


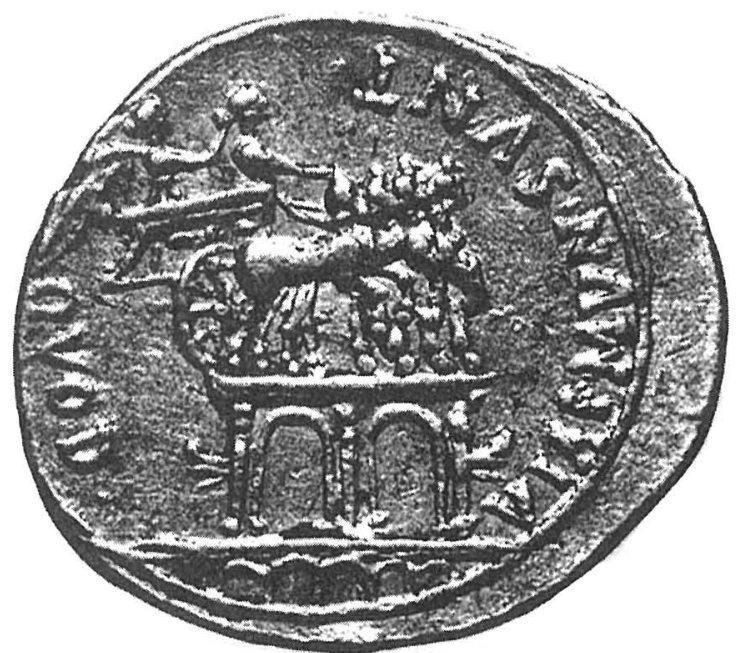

Fig. 5 - Denário de Augusto com a legenda quod viae mun(itae) sunt, comemorativo da reconstrução da Via Flaminia.

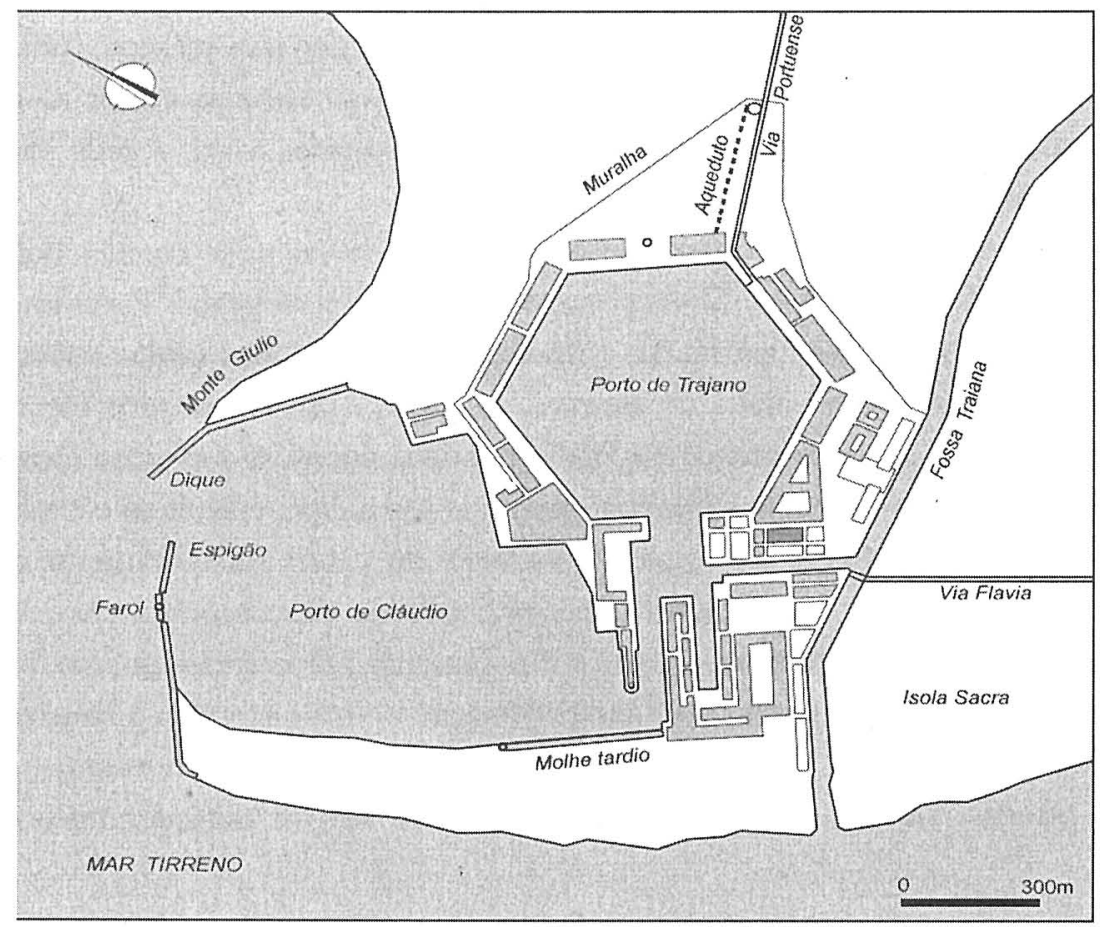

Fig. 6 - O complexo portuário de Óstia depois dos trabalhos de ampliação efectuados por Trajano 
Cláudio e a abertura de uma imponente doca escavada, ainda existente ${ }^{18}$, confirmam estas intenções.

Obras de tal envergadura eram caras e, ainda que necessárias, não deixaram de suscitar críticas por parte dos defensores de uma austeridade romana já pouco concordante com a realidade dos tempos. Referindo-se a Cláudio, Suetónio escreveu o seguinte: Iniciou grandes trabalhos, embora se preocupasse mais com o número deles do que com a sua utilidade: os principais são: o aqueduto começado por Caio, um canal de esgotamento para o lago Fucino e o porto de Óstiat. Fora da Itália, o traço deste tipo de construções portuárias é, naturalmente, bastante raro. Todavia, mesmo em áreas longínquas, subsistem vestígios de portos activos e de cuidada construção, bem adaptados às condições locais, caso, por exemplo, do porto flúvio-marítimo de Londinium (Londres), bem conhecido desde há alguns anos ${ }^{50}$. Os relevantes progressos verificados no estudo dos portos romanos no Mediterrâneo e no Atlântico contribuíram para confirmar a capacidade técnica revelada pelos Romanos na difícil área da construção portuária, apenas sugerida por Vitrúvio $^{51}$, ao mesmo tempo que levaram alguns arqueólogos a interrogar-se sobre o verdadeiro valor desses portos em termos económicos, considerando-os principalmente como grandes obras políticas ${ }^{52}$, o que nos parece algo exagerado, ainda que reconheçamos a importância simbólica dos monumentos na civilização romana.

É interessante constatar que as dúvidas expressas em relação aos portos pelos arqueólogos, no fundo inspiradas nalguns casos específicos e perfeitamente compreensíveis, não se estendem à rede viária, considerada globalmente como necessária e funcional, o que é verdade, mas nem por isso menos apta para assegurar determinados transportes pesados e em larga escala. Como seria possível enviar para Roma, por via terrestre, o azeite da Bética ou os mármores da Ática? Esta razão leva-nos a considerar um erro metodológico continuar o estudo das comunicações no Império Romano a partir de análises

. "Juvenal, Schol., XII, 75-76; T. Donaldson, Architectura Numismatica, Chicago, 19682, p.322-340; O. Testaguzza, The port of Rome, "Archaeology", 17, 1964, p.173-179.

"Suetónio, Claud., XX, 3.

${ }^{50}$ G. Milne, The Pont of Roman London, Londres, 1985.

"st Vitrúvio, De Arch., V, 13.

${ }^{52} \mathrm{Ph}$. Leveau, Richesses, investissements, dépenses: à la recherche des revenues des aristocracies municipales de I'Antiquité, "L'Origine des Richesses Dépensées dans la Ville Antique ", Aix-en-Provence, 1985, p.21-22. 
isoladas das suas diferentes componentes, terrestres, fluviais e marítimas. A unidade do Império e a integração progressiva das suas províncias europeias só foi concretizada através de um sistema de interfaces baseado numa diversidade de itinerários e meios de transporte. Uma simples observação do traçado de algumas das grandes estradas romanas esclarece de imediato esta circunstância, permitindo identificar um porto na extremidade ou no ponto inicial de uma via importante, como Cádis, Aquileia, Colónia ou Lião.

As condições climáticas pesaram fortemente na tipologia construtiva das estradas, como já referimos, fazendo com que nas províncias do Sul europeu as estradas de estrutura espessa fossem bastante invulgares, substituídas com frequência por simples pistas, melhoradas pontualmente por um troço consolidado, sobretudo nas proximidades de povoações importantes, e pelo lançamento de pontes, que podiam ser, no todo ou em parte, de madeira. Simplificando desta forma parte da rede viária de primeira categoria, podemos idealizar melhor o que seria o conjunto do sistema viário e compreender a dificuldade sentida pelos arqueólogos ao tentar identificar restos materiais de estradas indicadas no Itinerário de Antonino, completamente obliteradas na paisagem, mas que, a seu tempo, existiram como muitas outras de que nada sabemos.

Durante muito tempo a reconstituição das comunicações na Europa romana dependeu em larga medida dos documentos escritos que nos ficaram da Antiguidade, raros no que se refere a roteiros ou mapas, mas contando com abundantes testemunhos literários sobre viagens em terra e no mar ${ }^{53}$. No grupo dos primeiros situam-se o Itinerário de Antonino e a Cosmografia, vulgarmente conhecida por Anónimo de Ravena. O Itinerário é uma recolha monumental de 372 itinerários, ou seja, a indicação do percurso a seguir para viajar entre mansiones escolhidas pela sua importância, utilizando com frequência troços de diversas estradas. Este roteiro viário terá sido composto, talvez a partir de um mapa mural, nos finais do século III, ainda que não faltem investigadores que o atribuem à época de Caracala. Divulgado a partir do século XV, é a edição de $\mathrm{P}$. Wesseling, aparecida em 1735 em Amsterdão (Fig.7), que serve de base aos estudiosos modernos ${ }^{51}$. A bibliografia sobre o

${ }^{34}$ Chevallier, Voyages, p.7-15, 425-434; Dilke, p.112-129; B. Solway, Travel, itineraria and tabellaria, "Travel and Geography in the Roman Empire", Londres, 2001, p.22-60.

" P. Wesseling, Vetera Romanorum Itineraria, Amsterdão, 1735; J. Roldan Hervás, Itineraria Hispana. Fuentes antiguas para el estudio de las vías romanas en la Península Ibérica, 
Itinerário é enorme, pelo que não nos ocuparemos das diferentes hipóteses interpretativas que ela reflecte. Diremos apenas que, apesar de se tratar de um documento medíocre, o Itinerário de Antonino permite uma visão de conjunto dos principais eixos de comunicação terrestres, sobre os quais, nalguns casos, não temos mais informação.

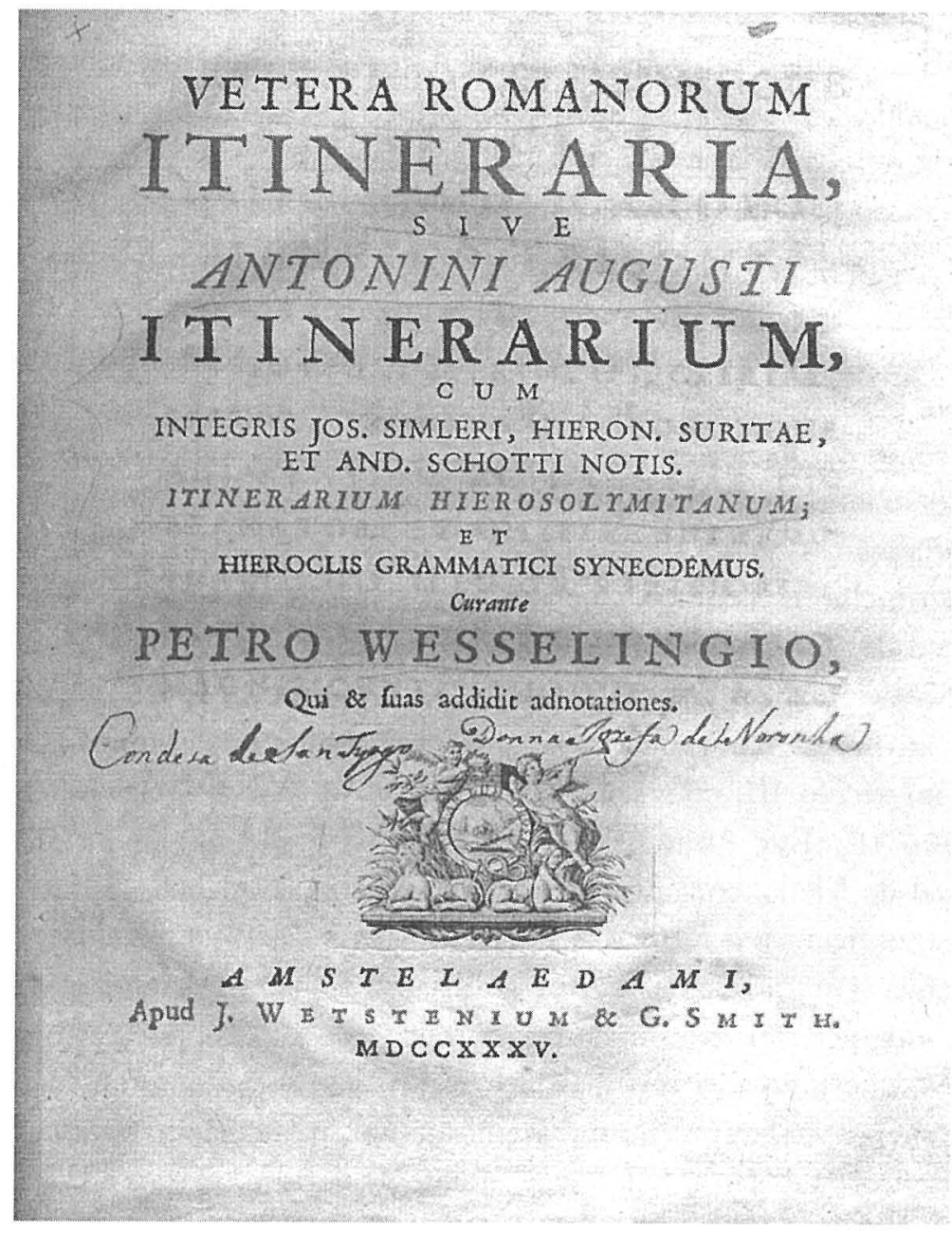

Fig. 7 - Frontispício da obra de P. Wesseling.

Madrid, 1975, p.19-37; P. Arnaut, L Itinéraire d'Antonin: un témoin de la littérature itinéraire du Bas Empire, "Geographia Antiqua”, 2, 1993, p.33-47. 
Quanto ao Anónimo de Ravena, é uma lista de topónimos e hidrónimos, sem indicação de distâncias intermédias, composta no século VII sobre documentação anterior, provavelmente um mapa viário, conhecido a partir da edição parisiense de 1688, de P. Porcheron. Na Cosmografia a confusão é absoluta, com a agravante de o autor ter procurado esconder a pobreza das fontes utilizadas inventando estranhas referências. Apenas um exemplo: as míticas amazonas Penthesileia e Marphisa surgem radicalmente transformadas em sexo e aptidões como Penthesileus e Marpesius, autores de uma descrição da Cólquida. Apesar de se tratar de um mau documento, a imagem deformada da rede viária que nos transmite não deixa de ser útil, usada cautelosamente, razão para que os investigadores se ocupem da Cosmografia $a^{35}$, expressão nostálgica de um tempo em que todos os caminhos iam dar a Roma, não a Ravena.

Existiram outros roteiros viários, cobrindo o conjunto do Império, infelizmente perdidos, assim como descrições específicas de determinados caminhos, como o Itinerarium Hierosolymitanum, redigido em 333, descrevendo o percurso entre Bordéus e Jerusalém, pela Itália e Balcãs, com uma meticulosa indicação da categoria das estações: civitas, mansio; mutatio ${ }^{36}$. Não estamos em melhores condições no que toca a mapas romanos, com a notável excepção da Tábua de Peutinger, assim designada por ter sido oferecida ao humanista germânico Konrad Peutinger, no século XVI. É uma cópia medieval de um mapa viário elaborado sobre uma fonte, ou fontes, do século I, talvez no século III, com contributos que se podem atribuir ao tempo de Teodósio II ${ }^{57}$. Este exemplar de itineraria picta encontra-se na Biblioteca Nacional de Viena, contando com 11 das 12 folhas originais, perdida a primeira, que figurava a maior parte da Hispânia e da Britânia, assim como a Mauritânia Tingitana. Apesar dos graves problemas de leitura que suscita, provocados pela forma estirada da representação e pelas dúvidas quanto ao objectivo que pretendia servir, parece seguro que se procurou evidenciar os pontos de cruzamento e entroncamento de vias, não faltando também a indicação destacada de faróis e de alguns grandes centros portuários e horrea $a^{38}$.

\footnotetext{
${ }^{35}$ Roldan Hervás, p.111-115; L. Dilleman, La cosmographie du Ravennate, "Collection Latomus”, 235, Bruxelas, 1997.

${ }^{56}$ Wesseling, p.549-617; Dilke, p.128-129.

${ }^{37}$ Roldan Hervás, p.106-110; Dilke, p.113-117.

${ }^{s *}$ Solway, p.43-4.7.
} 
É possível que as cartas e os roteiros viários que sobreviveram tenham sido copiados de documentos oficiais, embora seja difícil considerar que se tenha verificado uma cópia directa e integral, atendendo às características patenteadas, decorrentes do recurso a diversas fontes, oficiais e privadas. Os documentos resultantes deste processo complexo reflectem o estado da rede viária numa determinada época ou região, assim como os interesses dos eventuais utilizadores e até a forma como se efectuavam as deslocações, podendo certas omissões corresponder a trajectos fluviais ou marítimos.

Para esboçarmos as principais rotas marítimas na Europa romana, algumas já de venerável antiguidade no advento do Império, podemos recorrer aos raros périplos existentes, os quais, sendo obras de marcada intenção geográfica, não deixam de contribuir para o conhecimento das costas e dos pontos considerados relevantes para a navegação, nomeadamente cidades portuárias. Recordamos aqui a obra de Marciano de Heracleia, redigida sobre uma grande variedade de fontes, referentes quer ao Mediterrâneo, quer ao Atlântico $^{59}$. Muito mais importante, contando com a descrição de um total de 19 rotas, das quais 3 correspondem a trajectos no Atlântico, é o chamado Itinerarium Maritimum, também incluído na recolha de Wesseling. Com as distâncias indicadas em estádios, com excepção do longo percurso de cabotagem entre Óstia e Arles, para o qual a contagem é feita em milhas, este roteiro marítimo concede particular atenção às comunieações regionais, sobretudo a partir de portos italianos, iniciando-se na Hispânia, em direcção a África, quatro das travessias transmitidas pelo documento. Além de noticiar os pontos de passagem desta ou daquela rota, atribuindo uma atenção especial às ilhas, o Itinerarium Maritimum precisa a qualidade deles, o que representa um importante contributo para o conhecimento da navegação romana ${ }^{\text {in }}$.

Outro documento escrito que contribui para que possamos traçar as grandes rotas marítimas pelos finais do século III é o chamado Édito do Máximo, famoso documento exemplar da política de economia dirigida instaurada por Diocleciano. Com efeito, a propósito do preço dos fretes de transporte marítimo, o Édito faz referência, ainda que de forma abreviada, a determinadas rotas de longo curso, como, por exemplo, entre o Oriente e a

${ }^{37}$ M. P. Munõz, La Península Ibérica en Marciano de Heraclea, "Hispania Antiqua", VIII, 1978, p.89-110; Dilke, p.131-142.

${ }^{6}$ Wesseling, p.487-529; Roldan Hervás, p.102-105. O documento distingue portus, statio, positio e plagia. Sobre estas categorias portuárias: M. Besnier, Portus, "Dictionnaire des Antiquités Grecques et Romaines”, IV, Paris, s/d, p.595-596. 
Lusitânia ou entre a Hispânia e a África ${ }^{61}$. Finalmente, assim como os marcos miliários e as pontes ajudam a confirmar ou a identificar traçados viários, os achados subaquáticos representam, pelo avultado número de naufrágios registados a partir de meados do século passado, um importantíssimo meio de reconhecimento das rotas marítimas do mundo romano e do seu comércio (Fig.8), quer se trate de navegação de cabotagem, quer de longo curso ${ }^{62}$. Uma cuidadosa prospecção ao longo dos grandes rios não deixará de contribuir também para um melhor entendimento da forma como os transportes fluviais se integraram como parte fundamental do esquema de comunicações na Europa romana ${ }^{6.3}$, existindo já abundantes e promissores testemunhos acerca destas actividades específicas.

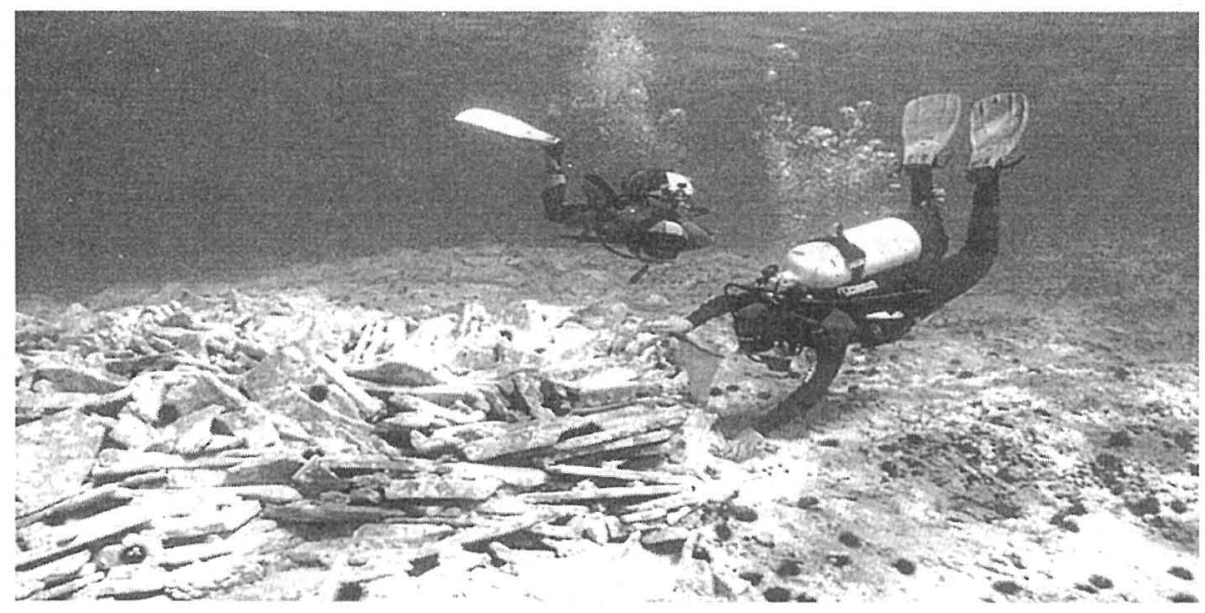

Fïg. 8 - Naufragado romano perto de Tarento, con carga de materiais de construção cerâmicos (Gentileza de Rita Auriemma).

Procurámos dar uma visão concentrada de alguns aspectos do que foram as comunicações na parte europeia do Império Romano, sem esquecer que muitos dos destinos em causa se encontravam, na área mediterrânica, fora da 192 Europa. Considerando a densidade de caminhos terrestres e aquáticos envolvidos, não é possível sequer esboçar-lhes um esquema muito geral, que não

${ }^{6}$ M. Giacchero, Edictum Diocletiani et Collegarum de pretis rerum venalium in integrum restitutum e latinis graecisque fiagmentis, Génova, 1974, p.220, 224.

${ }^{12}$ A. J. Parker, Ancient Shipwrecks of the Mediterranean and the Roman Proninces, Oxford, 1992. Este investigador recenseou 1259 naufrágios antigos, a esmagadora maioria dos quais no Mediterrâneo.

"Chevallier, Voies, p.228-232; Voyages, p.122-132. 
corresponderia senão vagamente à realidade de uma determinada época. Assim, apenas referiremos que os grandes eixos viários romanos irradiam normalmente de um centro administrativo importante, interligando-os, ou dirigindo-se para áreas de especial interesse económico, como os distritos mineiros, ou para as guarnições fronteiriças. No território italiano, Roma centralizou o sistema viário, logicamente, cabendo ao porto de Aquileia uma função semelhante em relação aos grandes eixos orientados para o limes danubiano. Ao longo do Danúbio corria uma importante estrada estratégica, o mesmo acontecendo a ocidente, pela margem esquerda do Reno. Aqui e ali havia pontos de travessia destes rios, que facilitavam quer eventuais operações militares, quer o comércio com o mundo bárbaro, como Moguntiacum (Mogúncia), no Reno, e Carnuntum (Petronell), no Danúbio. A partir da Gália Cisalpina, através dos Alpes, foram lançadas as grandes vias que comunicavam a Itália com as províncias ocidentais. Na Gália, o principal nó viário era a cidade de Lugdunum (Lião), centro de ruptura do tráfico fluvial no Ródano (Fig.9); na Hispânia, Emerita Augusta (Mérida), capital da Lusitânia, Caesaraugusta (Saragoça) e Toletum (Toledo) foram importantes centros viários; na Britânia, Londinium (Londres) conheceu a mesma função num território onde os aspectos estratégicos permaneceram pertinentes.

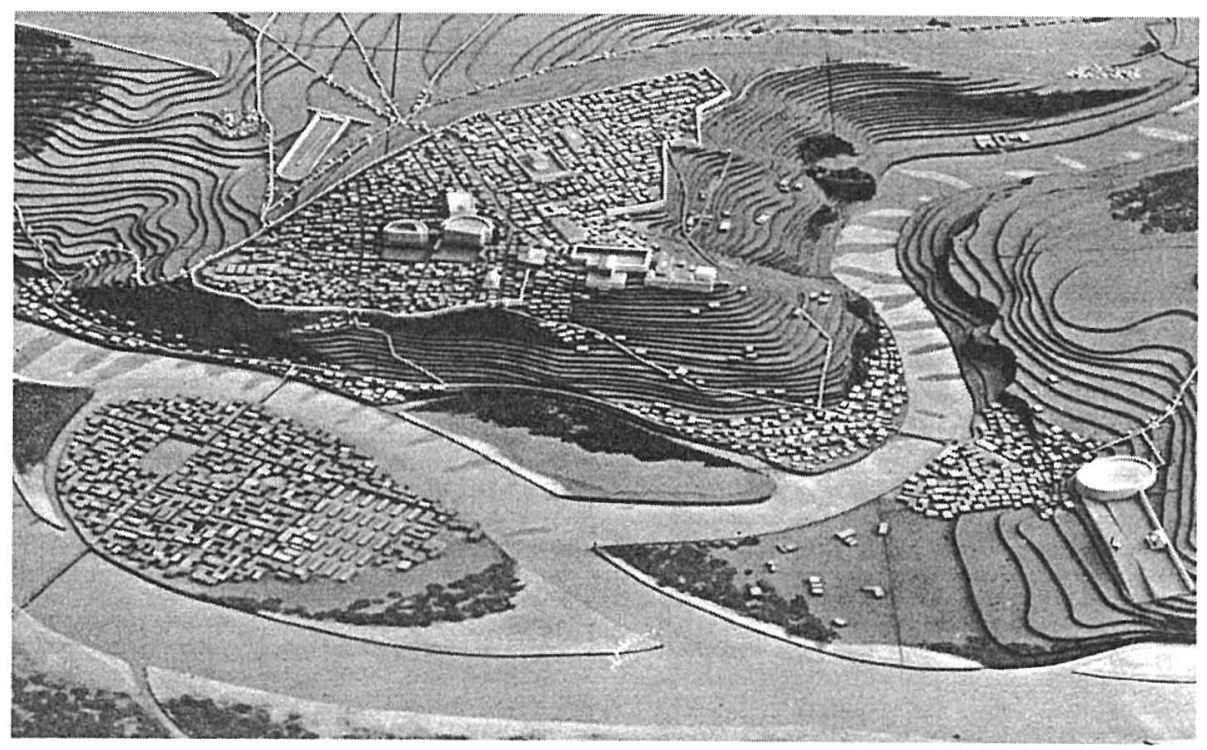

Fig. 9 - Maqueta de Lugdumum no século II, ilustrando a zona portuária e a confluência do Ródano e do Sona. 
Para lá do Adriático, na Dalmácia e províncias limítrofes, os principais eixos viários desenvolviam-se paralelos à costa e ao longo dos rios, sobretudo do Save e do Drave; mais a sul, o porto de Apolónia era o ponto inicial da Via Egnatia, que levava a Salónica através da Macedónia, continuando depois para a Mésia. Outra via, por Filipos, conduzia pela Trácia a Bizâncio. As comunicações terrestres eram particularmente difíceis na Grécia, onde Atenas estava em ligação com Apolónia e com Salónica; Corinto, pela sua posição, tinha também uma função importante nas comunicações terrestres e marítimas. A falta de rios navegáveis e as dificuldades da orografia eram de alguma forma compensadas pelas facilidades oferecidas à navegação durante a boa estação. Por fim, recordamos que nas ilhas mediterrânicas, com excepção da Sicília e da Sardenha, a rede viária era pouco desenvolvida, reflectindo aspectos da economia local que se contentava com caminhos sumários ${ }^{61}$.

Outra era a importância das ilhas no que se refere às rotas de longo curso ou de cabotagem, circunstância que está bem presente, por exemplo, no Itinerarium Maritimum. As rotas de cabotagem, ao longo das costas ou com pequenos percursos em mar alto, eram muito numerosas, podendo interessar apenas às relações de vizinhança próxima ou reflectindo, como no Itinerarium Maritimum a rota entre Óstia e Arles ${ }^{65}$, viagens bastante extensas. A prática normal da navegação nocturna na época imperial romana levou a viagens de longo curso ou de rota batida, sem escalas ou quase sem escalas, de vários dias de duração. No Mediterrâneo, a navegação era intensa a partir dos portos italianos para as costas da Dalmácia e para a Grécia, enquanto que as grandes rotas relacionadas com a anona uniam a Itália aos grandes portos norte-africanos de Alexandria e de Cartago, para o abastecimento de cereais através de uma imponente frota de navios de grandes dimensões, como o célebre $\hat{I}_{\text {sis }}$ descrito por Luciano ${ }^{66}$. As ligações com a Hispânia, em direcção ao Estreito de Gibraltar, faziam-se através de uma rota pela costa da Gália Narbonense ou através de uma rota directa pelo Estreito de Bonifácio e Arquipélago das Baleares, uma e outra bem documentadas pelos naufrágios com carregamentos de origem hispânica, com destaque para o azeite, os preparados piscícolas e os minérios, mais facilmente detectáveis.

\footnotetext{
"Chevallier, Voies, p.149-159; 176-186.

${ }^{15}$ Wesseling, p.497-508.

${ }^{66}$ Luciano, Nav, 4-14.
} 
A navegação não se limitava ao Mediterrâneo, uma vez que as referências literárias de época romana sobre a navegação atlântica começam a ser corroboradas por numerosos achados arqueológicos, em terra e no mar. A partir do Estreito de Gibraltar a costa atlântica foi percorrida pela navegação romana, apoiada em portos como Gades (Cádis), activo até ao século III, Olisipo (Lisboa), Brigantium (Corunha), Burdigala (Bordéus), Portus Namnetum (Nantes), Gesoriacum (Boulogne-sur-Mer) ou Londinium (Londres), bem como por muitos outros. A navegação atlântica oferecia perigos maiores a quem a utilizava, mas as margens de lucro eram muito grandes, uma vez que o transporte de produtos essenciais às tropas destacadas em grande número na Britânia e na Germânia se podia fazer recorrendo ao percurso pelo Atlântico, não sendo de descurar a navegação directa entre a Hispânia e a Britânia. Desta forma, a rota atlântica surge como uma alternativa viável ao transporte pelo Mediterrâneo até à costa da Narbonense e subsequente transporte pelos rios, com transbordo para ganhar por terra a rede fluvial fluindo para norte, muito mais caro ${ }^{67}$. A zona onde os problemas náuticos são mais complexos é a do Mar Cantábrico, entre Brigantium e a Aquitânia, mas achados como os do porto de Gijón e do Cabo Higuer são suficientes para garantir uma navegação regular neste sector específico ${ }^{68}$. Ainda que os naufragados romanos seguramente identificados no Atlântico sejam por enquanto poucos, achados como o dos Cortiçais, em Peniche ${ }^{67}$, onde se identificaram e estudam presentemente restos de um navio com um carregamento homogéneo de ânforas Haltern 70, mostram que a rota atlântica foi praticada normalmente, pelo menos por razões estratégicas, incontornáveis, confirmando o que Plínio afirmou: $A$ Gadibus ... Hispaniae et Galliarum circuitu totus hodie navigatur occidens ${ }^{70}$.

Não queremos terminar esta brevíssima referência às comunicações marítimas sem lembrar dois outros aspectos, o primeiro a propósito da função como traiectus, exercida ou não juntamente com outras por determinados portos, servindo de cabeça de linha de travessias rápidas entre costas próximas, caso de Baelo, junto a Tarifa, de Gesoriacum ou de Brindes, de onde se

${ }^{67}$ Greene, p.40-4.1 ; Cunliffe, p.382-383.

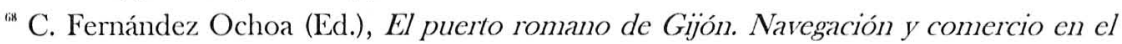
Cantábrico durante la Antigüedad, Gijón, 2003; Parker, p.218-219.

"Este naufrágio de época augustana está a ser investigado por uma equipa do Centro Nacional de Arqueologia Náutica e Subaquática (CNANS), com colaboração do Grupo de Estudos e Pesquisas Subaquáticas (GEPS), de Peniche, e da Universidade de Coimbra.

${ }^{70}$ Plínio, N.H., II, 167. 
ganhava a Mauritânia, a Britânia e a Macedónia. Outro aspecto que nem sempre tem sido devidamente considerado é o dos fretes de retorno, que explicam certas cargas que parecem economicamente pouco rentáveis, como os materiais cerâmicos de construção italianos em África ${ }^{71}$, cargas transportadas numa viagem de retorno de um porto para o qual foi conduzido o frete principal, justificativo da viagem.

Quanto às comunicações por via fluvial, devemos considerar a navegação regional, a navegação de transbordo de mercadorias desenvolvida sobre redes hidrográficas diferentes, em relação directa com a rede viária, e a navegação ao longo de rios de curso muito extenso. Daremos como exemplo da primeira a navegação no Guadalquivir, drenando a produção de azeite para os portos de embarque, como Sevilha ${ }^{72}$; em relação à segunda, a navegação no Ródano, sobretudo a partir do porto que existia na foz, ou de Arles, até Lião, onde as mercadorias eram desembarcadas para ganharem por terra outros rios, o Loire ou o Sena, que as faziam chegar ao seu destino ou a um novo trajecto marítimo ${ }^{73}$; em último lugar os grandes percursos fluviais, como os que se desenvolviam ao longo de rios como o Reno e o Danúbio, onde não faltou a presença de flotilhas militares, constituindo um elemento fundamental das comunicações, civis e militares, desta longa fronteira. Por isso, não faltam nestes cursos de água e seus principais afluentes testemunhos arqueológicos da navegação no período romano ${ }^{24}$, como a famosa inscrição de Trajano, regulamentando a navegação no rio, gravada na rocha no troço do Danúbio alterado pela construção da barragem de Djerdat, nas Portas de Ferro ${ }^{75}$, lembrança do pragmatismo da ordem imperial e do que ela representou na Europa de então.

"G. Ch.- Picard, La civilisation de I'Afrique romaine, Paris, 1959, p.87-88, 378.

${ }^{72}$ G. Chic, La navegación por el Guadalquivir cntre Córdoba y Sevilla en época romana, Ecija, 1990; S. Ordoñez, El puerto romano de Hispalis, "Puertos Fluviales Antiguos: Ciudades, Desarrollo e Infraestructuras”, Valência, 2003, p.59-79.

${ }^{73}$ J. L. Christol / J. L. Fiches, Le Rhône: batellerie et commerce dans I'Antiquité, "Gallia”, 56, 1999, p.141-155 ; L. Long / C. Sintes, Conmerce, maritime et fluvial aux cmbouchures du Rhône: le rôle d'Arles dans I'Antiquité, "Puertos Fluviales Antiguos. Ciudades, Desarrollo e Infraestruturas”, Valência, 2003, p.183-201.

"M. Zahariade / O. Bounegru, Roman ships on the Lower Danube: types and functions, "Crossroads in Ancient Shipbuilding”, Oxford, 1994, p.35-41; V. O. Hockman, Das Lager Altenburg, die Germanische Flotte und die römische Rheinschiffahrt, "Kölner Jahrbuch", 31, 1998, p.317-350.

${ }^{75}$ Chevallier, Voies, p.199. 
O transporte fluvial foi largamente garantido por corporações de nautae, muito numerosas e poderosas, de que existe uma abundante documentação. A sua importância na rede de comunicações era muito grande, tal como sucedia com as corporações ligadas ao transporte marítimo, e reconhecida pelas autoridades. Contavam entre os seus membros com uma parte significativa dos notáveis regionais, muito activos nas actividades sócio-políticas, participando estas associações com frequência em actos de evergetismo significativos, incluindo construção de monumentos públicos, como sucedeu, por exemplo, com os Nautae Parisiaci, que terão construído as Termas de Cluny, em Paris ${ }^{76}$. Além das facilidades que o transporte fluvial concedia à movimentação de pessoas e de mercadorias, por razões técnicas bem conhecidas, o custo do transporte pelos rios era muito mais baixo que o transporte terrestre. $\mathrm{Na}$ verdade, a economia oferecida pelo transporte fluvial era extremamente importante. Basta referir que, no Édito do Máximo, o transporte por carro carregado com 1200 libras, custava 20 denários por milha, enquanto que o transporte fluvial, a favor da corrente, custava um denário por módio (32 libras) para um percurso de 20 milhas, o que significa que o transporte terrestre custava cerca de onze vezes mais que o transporte fluvial". A importância do transporte pelas vias aquáticas interiores permitia não só movimentar mercadorias de forma pouco dispendiosa como constituía uma forma acessível de comunicar os centros do litoral com o interior, em especial quando o curso dos rios se adequava, como na Hispânia e na Gália. A vasta utilização dos rios e dos canais conjugada com as linhas férreas, durante o século XIX no Reino Unido $^{78}$, permite imaginar a forma como os Romanos se serviram dos rios $\mathrm{e}$ das vias como parte de um todo, seguindo, de alguma forma, a filosofia orgânica de Menénio Agripa.

A rede de comunicações funcionou também como símbolo tangível da ordem e da grandeza participada que Roma instituiu na Europa. Elementos fortes da paisagem, as estruturas necessárias ao estabelecimento das comunicações acabaram por constituir um factor permanente do processo de romanização. Vias e pontes foram utilizadas para projectar a mensagem de força e de unidade que esteve na base da ideologia imperial, com particular destaque

${ }^{76}$ A. Grenier, Manuel d'archéologie Gallo-Romaine, II, 2, 1934, p.535-560; H.-P. Eydoux, Monuments et trésors de la Gaule, Paris, 1962, p.78-84.

" M. H. Crawford / J. M. Reynolds, The Aezani Copy of the Prices Edict, "Zeitschrift fur Papyrologie und Epigraphik", 34, 1979, p.163-210 (XXXV, 38,105-106).

${ }^{7 x}$ Greene, p.34-35 ; M. E. Ware, Canals and Waterways, Princes Risborough, 2003. 
para as pontes ${ }^{79}$, por vezes ornadas com arcos honoríficos, como sucedia na Hispânia com o desaparecido Ianus Augusti, na fronteira da Bética, ou na formidável ponte de Alcântara (Fig.10), na Lusitânia ${ }^{80}$. A este propósito basta recordar quanto é significativo o que Plínio-o-Moço escreveu, congratulandose por Canínio pretender compor um poema sobre a conquista da Dácia, ao dirigir-se-lhe nos seguintes termos: Tu celebrarás novas pontes lançadas sobre os rios! $!^{\text {"I }}$.

Também os portos foram tomados como símbolos da grandeza romana, recebendo uma decoração arquitectónica muito variada, que a iconografia antiga não deixou de transmitir repetidamente. Lembramos, entre muitos e muitos exemplos disponíveis, apenas dois: as colunas que no porto de Brindes marcavam o fim da Via Appia, prolongada até este porto por Trajano (Fig. 11), e o arco, ainda do mesmo imperador, construído na extremidade do grande molhe do porto de Ancona, numa excelente posição cenográfica. Num âmbito diferente, no importante porto de Puteoli (Pozzuoli), na Campânia, os viajantes podiam conservar a memória do seu extraordinário molhe, prodigamente ornamentado, adquirindo frascos de vidro onde se representavam os principais monumentos da cidade, um dos quais se achou em Portugal, em Odemira $^{82}$. Esta prática confirma quer a antiguidade do hábito do souvenir no quotidiano, quer o valor da iconografia na difusão procurada dos fastos do Império.

As vias de comunicação contribuíram de forma decisiva para a integração plena das províncias no corpo imperial, mas, da mesma forma e com a mesma eficiência, permitiram e estimularam o desenvolvimento de unidades regionais, sobretudo a partir do século III, algumas delas preludiando uma história europeia ainda por escrever no tempo. Uma canção de gesta medieval francesa atribuía a um rei de Conimbre um túmulo antigo situado perto de Paris, na estrada para Orleães ${ }^{83}$. Tratar-se-ia de um natural de Conimbriga que um

198 F. S. Kleine, The trophy on the bridge and the Roman triumpls over nature, "L’Antiquité Classique", 60, 1991, p.182-192.

${ }^{*}$ P. Sillières, Les voies de communication de I'Hispanie méridionale, Paris, 1990, p.687, 795-798; A. Blanco Freijeiro, El puente de Alcántara en su contexto histórico, Madrid, 1977.

${ }^{21}$ Plínio-o-Moço, Epist., VIII, 4.

${ }^{n 2} \mathrm{~S}$. Ostrow, The topography of Puteoli and Baia in the light of glass llasks, "Puteoli", 3, 1979, p.77-40; J. M. Bairrão Oleiro, O vaso de vidro de Odemira, "Arquivo de Beja”, XX-XXI, 1963-1964, p.101-110.

${ }^{* 3}$ M. Bloch, Mélanges historiques, II, Paris, 1963, p.74.5. 
dia viajou até Lutetia? Nunca o saberemos, mas a simples possibilidade de que assim possa ter sido é suficiente para recriar a verdadeira imagem do que o desenvolvimento de comunicações regulares a longa distância, através de um espaço política e culturalmente unificado, permitiu.

Para logotipo deste congresso foi escolhido o tema mitológico do rapto de Europa, tão discutido nas suas possíveis interpretações ${ }^{\mathrm{kn}}$. Levada de forma

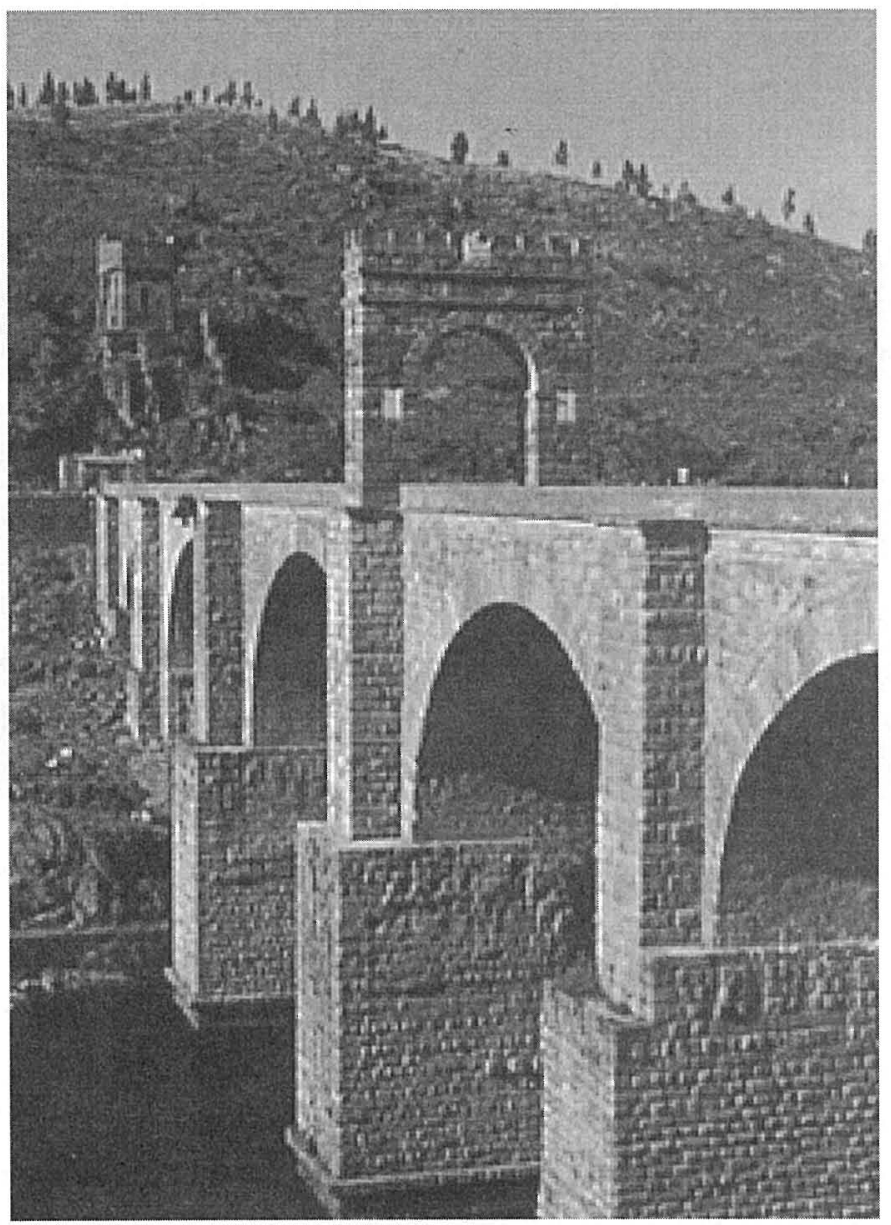

Fig. 10 - A ponte de Alcântara, construída sobre o Tejo por várias cidades lusitanas.

${ }^{*}$ R. Martin (Dir.), Dicionánio cultural da mitologia greco-romana, Lisboa, 1995, p.109. 


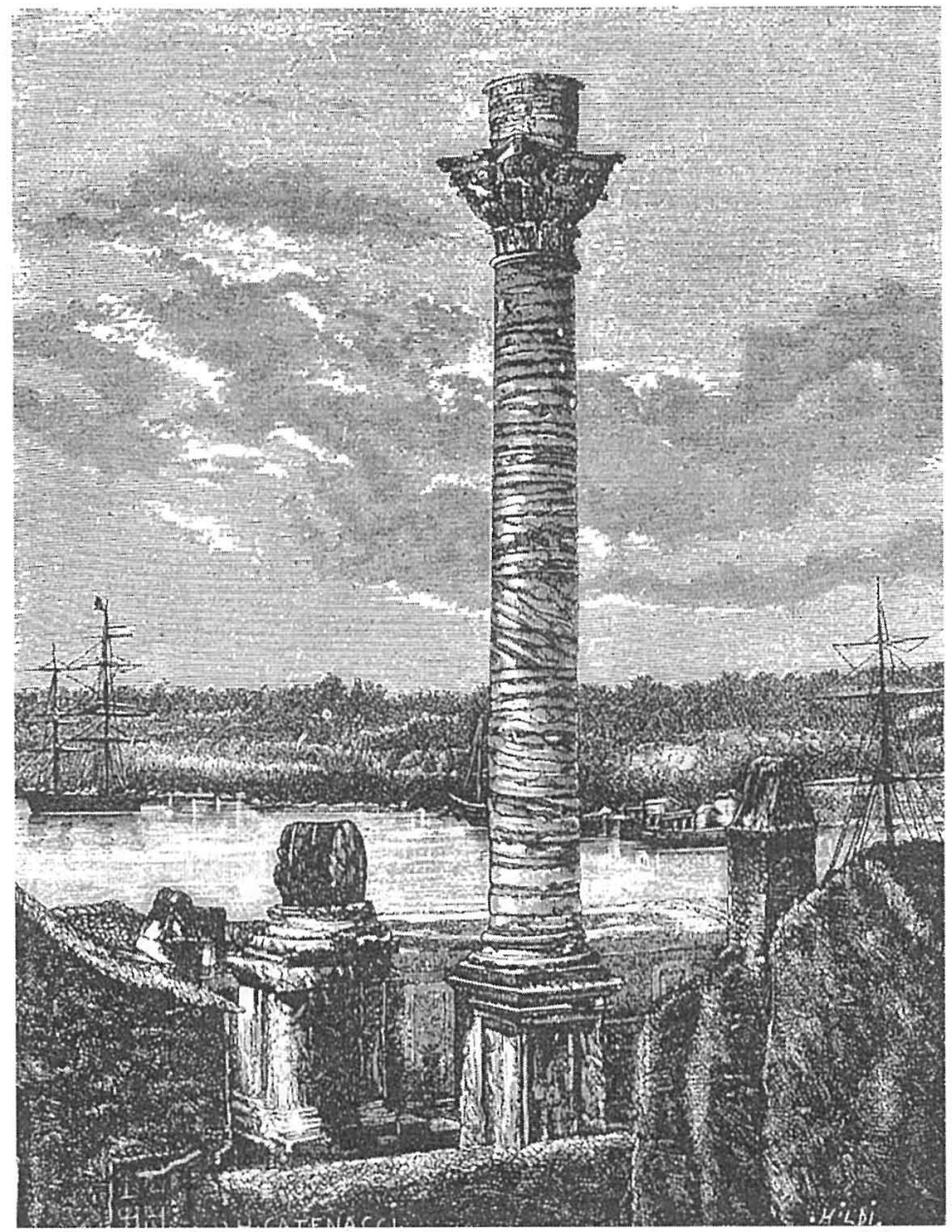

Fig. 11 - Gravura do século XIX figurando o porto de Brindisi com as colunas comemorativas da Via Appia.

dolosa para um mundo novo, Europa não deixa de ser também uma noiva, na linha do rapto-casamento vulgar em tantas sociedades arcaicas. Devemos interrogar-nos, agora, quanto ao sentido dos novos caminhos sobre os quais a Europa segue ou é levada, louca ou mitómana, como poeticamente David Mourão Ferreira hesitava em interpretá-la ${ }^{85}$, caminhos cuja obscuridade emba-

${ }^{25}$ D. Mourão Ferreira, Retrato de rapariga, “A Arte de Amar”, Lisboa, 1992, p.123. 
cia a génese de uma nova Europa, tal como é obscura a relação entre o conceito geográfico e a heróna do mito. Voltemos, para terminar, ao realismo romano, recordando o que Plínio-o-Velho escreveu acerca do tema que aqui tratámos: O poder de Roma conferiu unidade ao mundo. Todos devem reconhecer os serviços que ela prestou aos homens, facilitando as suas relações e permitindo-lhes usufruir em comum os beneficios da paz ${ }^{86}$. 
(Página deixada propositadamente em branco) 


\title{
CONSTANTINO EL GRANDE: DESCONTRUCCIÓN Y CONSTRUCCIÓN DE UN IMPÉRIO
}

\author{
Marc Mayer \\ (Universitat de Barcelona \\ Università di Macerata)
}

\section{Constantino: una voluntad de reinar}

No cabe duda de que una de las personalidades más fascinantes y discutidas de la historia romana es el emperador Constantino el Grande, héroe para unos, santo para otros, oportunista político para otros cuantos y así un largo étcetera de pareceres y de opiniones varias y contradictorias que jalonan la historia, quizás excepcional, del que fue seguramente un hombre de su tiempo y como tal acertó y erró. Su reinado sin embargo se ha considerado, y sin duda con razón, un momento de cambio y casi un momento de ruptura con una tradición anterior para iniciar una nueva singladura del Imperio romano: el Imperio cristiano. También en este punto hemos de convenir que el papel de Constantino fue muy importante, aunque no han de confundirse las consecuencias de unos hechos y actuaciones con lo que sucedió realmente. Los historiadores ante este personaje tienden a perder en muchas ocasiones la voluntad de objetividad, o al menos se les hace difícil mantener la distancia necesaria entre los hechos históricos y las propias convicciones o sentimientos. Este hecho se produce además en estudiosos que mantienen entre sí puntos de vista diametralmente opuestos, es decir se dan todo tipo de casos entre partidarios acérrimos, o incluso apologetas, de Constantino, como entre aquellos, que en ocasiones bajo capa de buscar una verdad histórica, que consideran 
escondida por la tradición, no pueden disimular su repulsión por el personaje. Lo más singular es que ambas posiciones, con todo tipo de matices, se den entre historiadores de puntos de vista históricos, metodológicos, políticos y religiosos del mismo signo. Quizás una de las grandezas de Constantino, evidentemente inconsciente y no buscada por su parte, es no dejar a nadie indiferente.

Creo que este breve trabajo no dejará tampoco indiferentes, primero a los oyentes, casi obligados, y más tarde a los lectores, si los merece. Como todos antes de mi han hecho, o al menos deberían haberlo intentado, me parece que he tomado las precauciones de distancia necesarias para no analizar más que hechos históricos, pero no me engaño al respecto: las fuentes en el caso de Constantino, al menos las fundamentales, son verdaderamente opiniones; están ya mediatizadas y el análisis historiográfico lo revela prácticamente en todos los casos. No creo con esto revelar nada nuevo a nadie, pero prefiero jugar con las cartas descubiertas. Para todos resulta dificil mantener la distancia histórica y juzgar con objetividad las opiniones ajenas, ya que a veces corremos el riesgo de aceptar como más convincentes las que en realidad, y lo hacemos con honesta inconsciencia, son las que más se avienen con nuestras propias vivencias y creencias. No creo que estas páginas, pese a todas estas cautelas, estén libres de haber sucumbido a estos peligros a pesar de que la intención era la única posible: mantener una razonable objetividad, conscientes de lo dificil que es alcanzarla, especialmente en un tema como éste. Por ello querríamos evitar juzgar y limitarnos, en la medida de lo posible, a describir, aunque la descripción ya sea por sí misma, inevitablemente, una selección y por tanto un juicio.

El enfoque que hemos elegido quizás pueda sorprender a algunos ya que en lugar de haber elegido un tema tan llamativo como el cambio que representa Constantino, y la inflexión que su reinado deja como herencia al Imperio, o incluso aspectos, mucho más opinables, como la personalidad de Constantinö o su sinceridad o fingimiento ante el cristianismo, nos adentramos en un tema mucho más político: su concepción del poder imperial y el reflejo de la misma en la entidad territorial del Imperio. Un tema que puede hoy, cuando la Unión Europea sufre la crisis anterior a transformarse en un "Imperio mediterraneo" articulado en torno al mare nostrum, o si se quiere internum, romano, resultar de alguna enjundia y sin duda de una cierta actualidad en sus problemas y quizás de una cierta prospectiva en sus soluciones. La valoración de Eutropio como medius princeps a partir de la mitad de su 
reinado se opone a optimus princeps como lo fue al inicio. Sobre esta base de medius princeps, poco favorable, viene a la mente lo que podría ser, en cambio, una buena definición de Constantino como hombre de su tiempo: la busqueda del compromiso de una via media, la mediocritas, en sentido horaciano, como camino hacia el equilibrio. Es muy posible que Constantino pueda ser explicado al menos politicamente sobre esta base.

\section{Los hitos de un largo reinado.}

Un breve resumen historico puede trazarse a partir de las celebraciones de su reinado: decennalia, vicennalia y tricennalia.

Antes de ello es necesario detenerse en lo que cuenta el panegirista del 310 que nos habla de una vinculación de Constancio Cloro y Constantino con Claudio el Gótico, en una clara desvinculacion de la ideologia tetrárquica; igualmente el sueño que liga a Constantino con Apolo, divinidad protectora del emperador Claudio el Gótico, y a través de él con el Sol Invictus, tiene su importancia para los acontecimientos posteriores.

Los decennalia han sido precedidos por la victoria sobre Majencio junto al puente Milvio y el nuevo sueño que lo vincula al cristianismo y al signo de la cruz. La entrada en Roma y el controvertido episodio de la visita o no al templo de Júpiter abre naturalmente la posibilidad de su conversio en aquel momento. Hay que destacar en la disposición conocida como edicto de Milán que consagra la tolerancia religiosa y la recuperacion de los bienes de la iglesia y de los cristianos. Se inicia además un gran interés del emperador por mediar e intervenir en los problemas internos del cristianismo. El arco de Constantino en Roma es un homenaje a este momento e indica en su inscripcion una actuación del emperador provocada por un ambiguo "instinctu divinitatis". La construcción de basílicas cristianas por donación del emperador darán una nueva facies a Roma.

Los vicennalia van precedidos por la presencia de Constantino en el Concilio de Nicea. El llamado símbolo de Nicea irá marcado por la voluntad mediadora del emperador en los problemas causados por el arrianismo. La derrota de Licinio, casado con su hermana Constanza, y la posterior ejecución de éste y de su hijo Liciniano, de 11 años y César con dos de los hijos de Constantino, parecen iniciar una serie de crueles ajustes dinásticos que se continúan con la ejecucíon de Crispo hijo del proprio emperador y con la 
muerte en un baño sobrecalentado de Fausta, la emperatriz. Las explicaciones son muy vagas y sobre la relación entre los dos ejecutados corren todo tipo de habladurias. En este momento se ha querido situar de nuevo la conversio de Constantino producida por el arrepentimiento. Constantino es ya único emperador. En Oriente las iniciativas del emperador y de su madre y única emperatriz Helena marcan una nueva monumentalización y unos itinerarios de piedad en Tierra Santa que substituyen a los santuarios paganos de Asia Menor.

Los trecennalia están marcados por la construcción de la Nova Roma, Constantinopolis. Los copiosos gastos que esto provoca son seguramente sufragados en parte con la confiscación de bienes y tesoros de los templos paganos, que tiene efectos secundarios importantes en la decadencia económica de ciertas ciudades. Hay que señalar la construcción en Constantinopolis de la Basílica de los 12 apóstoles, con doce cenotafios presididos por la tumba del proprio emperador. Su bautismo se producirá en Nicomedia en el momento mismo de su muerte.

Si nos fijamos en la fama póstuma de Constantino resulta claro que toda una serie de leyendas como la del emperador leproso, muy antiguas lo vinculan con una conversio y un sometimiento a la iglesia representada por el papa Silvestre I, que dará después origen al llamado Constitutum Constantinianum y que pretenderá justificar el dominio de la Iglesia de Roma sobre la ciudad y el territorio de Italia. Una pretendida disposición que será objeto históricamente de muchas controversias y desmentidos entre el año mil y el humanismo.

Constantino por otra parte será para algunos modelo o espejo de príncipes y para otros como ciertos movimientos pietistas europeos de la Ilustración un simple oportunista desvinculado de todo tipo de escrúpulo religioso. Las teorías de J. Burckhardt tendrían como ha demostrado S. Mazzarino este origen.

En el medioevo Constantino entra en el mundo de las leyendas y de la materia de Bretaña como un caballero de novela y es representado en relieves escultóricos. Hay que destacar además que las formas artísticas surgidas en su reinado se consolidan y crean un arte oficial que, incluso en ámbito religioso, se canoniza y pervive.

La Iglesia ortodoxa oriental lo considerará santo, como un isoapóstol, y lo situará junto a san Pablo. En suma toda una serie de factores positivos y negativos pero que en ningún caso dejan, como ya hemos dicho, a nadie 
indiferente. Se trata de un hombre de su tiempo que vive en un momento de transición, que utiliza los medios y métodos políticos de su momento y que tiene la clarividencia de ver la importancia del Cristianismo, aunque busca al mismo tiempo un equilibrio tolerante que le permita gobernar el Imperio que de nuevo ha reunificado y realizar los proyectos que tiene en mente y que ve como un imponente monumento a su memoria, consciente de que su actitud ante los cristianos favorece de forma decisiva este intento.

Acabado este rápido resumen conviene sin embargo, aún repitiéndonos, detenernos a hacer un cierto memorandum biográfico más detallado de Constantino para adentrarnos a continuación en las posibles intenciones y condicionamientos de la Tetrarquía, rota intencionadamente, por Constantino y no sólo por él, para acabar viendo el proceso de reunificación de un Imperio llevado a cabo con pragmatismo y tesón con una planificación, o mejor voluntad política, muy clara, que se adapta a las circunstancias de cada momento sin abandonar su objetivo final. Adelanto ya desde ahora mi conclusión: Constantino quiso siempre reunificar el Imperio dividido, con una aparente paradoja para mantenerlo unido, por el sistema tetrárquico, o al menos lo decidió muy tempranamente. Sus pasos van siempre dirigidos hacia este objetivo y pueden ser leídas desde este prisma todas sus actuaciones simbólicas y sus celebraciones. Un ritmo constante pero lento, en la esperanza de un largo reinado, que el tiempo no desmintió.

\section{El camino que lleva al imperio.}

Nacido en Naissus (Nis, Serbia) el 27 de febrero de un año entre 271 y 288, y muy posiblemente entre 272-273, es hijo de Constancio Cloro, que primero fue prefecto del pretorio y después desde 293 césar en las provincias occidentales siendo Galerio el otro césar. Su madre Helena había convivido con Constancio Cloro por muchos años cuando este era sólo un brillante oficial. La tradición la describe como una tabernera o mejor una sirviente de posada, stabularia, natural de Bitinia. Será Ambrosio de Milán quien dirá que pasó de los stabula a la púrpura. Constancio Cloro se vió obligado por su ambición a renunciar a ella y a casarse con la hija de Eutropia, la mujer de Maximiano, de nombre Teodora, quizás cristiana como se sospecha también de su madre. Constancio tuvo con ella seis hijos que fueron por tanto hermanastros de Constantino, el cual no tomó jamás medidas contra ellos una 
vez asumido el poder, circunscribiendo a Teodora en la ciudad de la Galia y sirviéndose de ellos y en especial de su hermanastra Constanza para su política dinástica. Helena cobra progresiva fuerza en el reinado de su hijo hasta llegar a convertirse, ya muy avanzado el reinado, en única Augusta. Ignoramos, pero intuímos que debió de ser una mujer hábil y enérgica con ideas religiosas claras, aunque no debemos, a falta de documentos probatorios, dejarnos llevar por al tentación de considerarla uno de los motores de la acción de su hijo en especial en materia familiar y de religión.

En 305 se produce la abdicación de Diocleciano y también la de su colega y amigo Maximiano. Diocleciano quiere poner a prueba el sistema tetrárquico por él instituído y no duda para ello en sacrificar su poder. Los nuevos Augustos son Galerio y Constancio Cloro y los nuevos Césares son Maximino Daza y Severo. Constantino, que había vivido junto a Dioclecianio en Nicomedia y había participado en campañas al flanco de Galerio y de Diocleciano desde 293, queda al margen. Su no consideración como nuevo César era muy coherente con el pensamiento político de Diocleciano de no seguir vínculos de sangre sino los estrictamente políticos, por mucho que la vinculación entre los tetrarcas era de parentesco por alianza de una forma buscada. Constantino que había permanecido en Nicomedia hasta aquel momento vuelve hacia Occidente junto a su padre. Tal como no se ha descartado que Constantino pudiera ser casi un rehén en la corte de Diocleciano, su no inclusión en la sucesión tetrárquica ha sido interpretada como una postergación, y su marcha a Occidente casi como una huída en busca de una seguridad que en Nicomedia parecía no tener en las nuevas circunstancias.

La permanencia de Constantino junto a Constancio dura poco. Es una verdadera usurpación la que se inicia al ser proclamado por las fuerzas de su padre como Augusto en Britannia, en Eboracum, el dia 25 de julio del año 306, en el momento de la muerte de éste. Galerio, con un realismo que, sin embargo, lo aparta de los principios tetrárquicos, le reconoce sólo como César elevando al grado de Augusto a uno de los césares "legítimos": Severo. Constantino no es el único motivo de preocupación para el sistema tetrárquico. Majencio hijo de Maximiano, despechado en sus ambiciones, era reconocido, el 26 de octubre del 306, como emperador en la parte occidental del Imperio con capital en la misma Roma. Su padre secunda en un principio la operación aunque más tarde, queriendo de nuevo el protagonismo se opondrá a su proprio hijo. En 307 Maximiano y Majencio se enfrentan y 
vencen al Augusto "légitimo", Severo. En 308 se produce la proclamación de Licinio como Augusto, como consecuencia de la denominada conferencia entre los emperadores en Carnuntum el 11 de noviembre.

Maximiano, por su parte, se apresura a reconocer a Constantino, esta vez como Augusto, en una reunión en Tréveris y le promete en matrimonio a su hija Fausta, habida con su mujer Eutropia, una niña en aquel momento. Constantino ya como Augusto se denominará con el epíteto Herculius. El matrimonio con Fausta tendrá como consecuencia, como sucedió con su padre y Helena, la postergación de quien convivía con él y de quien tuvo a su hijo Crispo: Minervina. Del matrimonio con Fausta, consumado algunos años después, tuvo tres hijos: Constantino II, Constancio II y Constante; y dos hijas: Constantina, casada entre el 351y el 354 con el césar Gallus, y Helena que casó con Juliano, llamado por la tradición cristiana el Apóstata, emperador entre 361 y 363.

La amonedación de Constantino insistirá en aquellos momentos en la figura de Sol imvictus, que no se ha dudado en identificar como una trasposición del Apolo visto en una imagen onírica del primer sueño de Constantino del que se hace eco el panegirísta del 310 y que antecedió a la victoria sobre Maximiano, como veremos acto seguido.

Buscará además, y éste es un factor que conviene no olvidar, una legitimidad distinta de la complicación tetrárquica y aprovechará el parentesco de su padre con Claudio II el Gótico, bajo quien también había servido. No podemos de nuevo pensar en el paralelo de Augusto que buscará también una filiación no natural, aunque en su caso divina. Supone este hecho casi una refundación familiar por quien pretende ser el constructor de una nueva dinastía. En un trabajo en muy otro sentido, Baldini destaca la vinculación a través de Constancio Cloro con Claudio el Gótico, pero buscando en el fondo la devotio por parte de los soldados. El panegirista del 307 se detendrá en las virtudes excelsas de Constantino y en la inteligencia de Maximiano de reconocerlo como yerno y sucesor, en la misma línea, ya oficial, de buscar cuantas más "legitimidades" pudieran sumarse.

En el año 310 se produce el fin de la usurpación de Maximiano; Constantino lo vence primero, y lo fuerza seguramente a suicidarse después de la batalla de Massalia. El panegirista del 310 nos narrará estos hechos, como simbólicos e insistirá en un sueño o visión de Constantino, al que se le aparece Apolo, anunciador también de la grandeza de Octavio Augusto, y le profetiza un futuro brillante en un reinado de treinta años. Las bases de la 
teoría del poder de Constantino están ya en aquel momento bien asentadas, a reserva del ritmo y de lo que vayan deparando las circunstancias. Apolo en aquel momento se sobrepone facilmente al Helio, Sol invictus, lo que constituye, y las monedas como hemos dicho lo reflejan, una momentánea teología del poder.

Galerio muere en 312 y Constantino emprende en aquel momento una campaña inevitable para sus objetivos: marcha contra Majencio, su cuñado, emperador irregular desde siempre, aliado suyo por un tiempo y ahora de acuerdo con la conveniencia política usurpador: tyrannus.

La batalla del puente Milvio, el 28 de octubre del 308, sella el destino de Constantino. No vamos a entrar ahora sobre los condicionantes de la batalla, que por un error táctico condujo a la muerte a Majencio al no poderse retirar sus fuerzas hacia Roma, después de una maniobra seguramente exploratoria, al quedar atrapadas entre el Tíber y sus enemigos. La muerte de Majencio en el Tíber produce una rápida victoria para Constantino, no obligado a poner sitio a Roma, en aquel momento casi inexpugnable. La victoria será atribuída a la intervención divina anunciada a Constantino en un nuevo sueño en el curso del cual recibe la inspiración de marcar sus fuerzas con una aspa en el escudo cuyo vertice derecho estaba curvado, evidentemente y buscadamente entendido después como un crismón. La descripción de Lactancio (De mort. 44, 3-5) en este punto parece la más fiable y el símbolo, ya preexistente, debió ser sentido como un elemento de buen augurio y de protección por parte de los soldados, evidentemente no cristianos, y en modo alguno como una marca desconocida; la contraseña por otra parte identificaba claramente una de las dos facciones enfrentadas.

Evidentemente no tenemos noticia alguna en Lactancio sobre la presencia de un lábaro. Puede ser útil aquí recordar la hipótesis de P. Bruun para quien crismón y lábaro no son vistos por los soldados como símbolo religioso sino propiciatorio y como recuerdo después de la victoria pasó a popularizarse entre los cristianos.

La tradición en este punto se complica ya que se ha querido contraponer al sueño de Constantino la consulta por parte de Majencio de los libros sibilinos. La superstición del tirano frente a la inspiración divina de un emperador que se convierte al cristianismo. La traducción posterior en el arco de Constantino de este hecho como instictu divinitatis da la justa medida de la ambigüedad ideológica que acompaña a la intervención divina. Hay que sumar a ello, como se acostumbra a acotar en este punto, que Constantino continuó 
ostentando y manteniendo hasta el final de su reinado la condición de pontifex maximus.

Licinio derrotará en el año siguiente, el 313, a Maximino Daza y en este mismo año muere también Diocleciano. Como consecuencia quedarán Constantino y Licinio como únicos emperadores. La crisis del sistema tetrárquico es, más allá de proclamas y enmascaramientos, un hecho. Los dos emperadores se reunen en Milán ese mismo año, al final del 312, para pactar las actuaciones futuras y confirman el decreto de tolerancia religiosa de Galerio, del 30 de abril del 311, en una línea política conocida y practicada entre otros por Majencio en el último año y medio de su reinado. Esta disposición, que Eusebio de Cesarea magnifica y considera una norma absoluta llevada a la perfección, "nómos teleótatos", por obra de Constantino, es lo que la historiografía tradicional conoce con el nombre de "edicto de Milán”, interpretado como un reconocimiento definitivo del cristianismo. El encuentro de Milán con Licinio traerá consigo, en la más pura tradición tetrárquica, la boda de éste con Constanza hermanastra de Constantino. El llamado "edicto de Milán del 313", cuya aún discutida realidad ya hemos comentado, será el punto de partida de un ensalzamiento cristiano irrefrenable de Constantino. Al mismo tiempo se perpetuará una leyenda sobre un Majencio brujo, adultero y un verdadero Heliogabalo, consideración esta última que curiosamente compartirá con Constantino, objeto también de la furia de detractores. Majencio, en realidad un gran restaurador de la ciudad de Roma, aparecerá como un tirano y su obra vendrá atribuída al nuevo emperador.

De aquí nacerá un estilo biográfico, cercano a la hagiografía, para contar los hechos de Constantino. Eusebio lo considerará, más que como un Ciro o un Alejandro, aunque no faltan tampoco imágenes panegíricas de este tipo, como un nuevo Moisés. Los silencios, la omisión de nombres, el encomio acentuarán el tono hagiográfico de la biografía eusebiana.

Si el panegirista del 313 constituye una excelente fuente para comprender el contexto ideológico de los quinquennalia de Constantino, resulta también indispensable para comprender la secuenia de hechos que siguieron a la batalla del puente Milvio.

El tema se centra en la entrada, que no triunfo, de Constantino en la ciudad de Roma después de la batalla. El rápido paso de Constantino hasta llegar al Palatino sustrayéndose a los ojos, deseosos de contemplarle, de los ciudadanos ha sido la clave para que se entendiera desde el cardenal Baronio 
y Lenain de Tillemont hasta la historiografía decimonónica y la actual que no se produjo un ascenso al Capitolio para honrar a Júpiter óptimo máximo por la victoria. Las interpretaciones han sido muchas y desde J. Burckhardt que consideraba simplemente un oportunismo de Constantino este hecho, si en verdad no se produjo, a quienes como S. Mazzarino o A. Alföldi creen que el cristianismo incipiente del emperador le condujo a no hacerlo. Otros, como en época muy reciente A. Fraschetti, creen en una verdadera conversión o como T. Barnes en una verdadera inclinación cristiana desde aquel momento. No vamos a entrar en esta espinosa cuestión, pero conviene notar que no hay en el panegirista noticia de un explícito rechazo por parte del emperador a subir al Capitolio como se producirá efectivamente más tarde y que la omisión del hecho, si tuvo lugar podría responder a la buscada ambigüedad oficial del momento. El rápido paso por la ciudad y el rápido refugio en el Palatino es perfectamete comprensible por la integridad todavía de una gran parte de las fuerzas fieles a Majencio y la inseguridad sobre la reacción de los habitantes de Roma ante Constantino. La disolución de las fuerzas, como los equites singulares, más fieles a Majencio y la reutilización de los espacios de sus cuarteles, parece inscribirse coherentemente en este cuadro.

La publica laetitia que al decir del panegirista acompañó, si no a un verdadero triunfo, si a un acceso casi triunfal se limitó a una adlocutio desde los rostra. La historiografía cristiana va más allá Eusebio, como ya hemos dicho, lo compara con Moisés guiando al pueblo hebreo y atravesando el mar Rojo, paralelo poco afortunado e inexacto, pero muy significativo para ilustrar la victoria sobre un Majencio que cruza el Tíber por un puente de barcas y muere ahogado en él. El proprio Constantino se presenta como liberator et restitutor, frente a un Majencio que se presentaba como conservator urbis suae y efectivamente hizo grandes obras, entre el 306 y el 312 , entre las cuales la restauración del templo de Venus y Roma y del circo Máximo. Sin duda alguna una razón más para el sobrepujamiento y el ensalzamiento oficial áulico y especialmente cristiano.

Se inicia ya en el 312 una nueva etapa de reutilización de los elementos antiguos en las obras constantinianas, la compleja cuestión de los spolia debe quedar por ahora al margen, en un intento de rivalizar con las de Majencio de las que se apropia, como es el caso de la estatua colosal en el ábside de la basílica que lleva hoy todavía el nombre de este último. Hay que valorar convenientemente la insistencia del emperador, en mostrar su voluntad, casi como un privado, de proteger el nuevo culto cristiano en la Urbe frente a la 
aristocracia tradicional. Nace así la basílica primera de San Juan de Letrán, junto a la llamada pretendidamente domus Faustae, que últimamento ha sido objeto de precisiones importantísimas por parte de P. Liverani respecto a las anteriores interpretaciones. Será ésta la primera donación de propiedades, que en este caso afectó los cuarteles de los equites singulares que había disuelto por su fidelidad a Majencio. Se ha querido ver este edificio como si en realidad se tratara casi de un ex-voto por la victoria "instinctu divinitatis", y por ello concebido como un aula de aparato o de recepción dedicada al proprio Cristo Rey, y de aquí vendría su forma basilical, que tendrá una gran continuidad. Probablemente en este tipo de edificios haya tenido su origen la episcopalis audientia que según P. Brown constituye la primera corte episcopal y es la clave del futuro.

En este sentido hay que recordar que más adelante el Senado lo honrará con un arco el 315, para el que usará spolia de los optimi principes anteriores, quizás reutilizando un arco preexistente y realizando incluso actualizaciones de retratos. La ambigúedad del Senado es evidente y su paganismo en aquel momento un hecho probado. Las nuevas construcciones constantinianas entre 320 y 326, y especialmente la basílica de San Pedro, iluminan lo que pretende ser una lección y la constatación de una elección que no intenta buscar rivalidad alguna con la aristocracia senatorial. Incluso la continua congregatio fragmentorum doctorum, que da auctoritas y que es un hecho buscado y típico desde el siglo I d.C., se desarrollará, a partir de este momento, en un grado nunca visto y con una carga ideológica propia de la época.

Constantino empieza a intervenir inmediatamente en cuestiones cristianas especialmente en Africa. El donatismo, al igual que en el 350 hará Novaciano, niega que el arrepentimiento para los lapsi, es decir aquellos que habían cedido durante las persecuciones, sea suficiente, en contra de lo que afirma por ejemplo Cipriano. El obispo Ceciliano y el propio emperador eran en este caso antidonatistas. El enfrentamiento de la iglesia de los martires contra los que considera traditores, a raíz del edicto de persecución del 303, es en aquel momento muy fuerte y por este motivo se provocan tumultos en las ciudades de Africa. Para evitarlos resulta claro que Constantino prefiere la posición tolerante del obispo Ceciliano y es un hecho notable que el emperador ordene que se imponga lo mantenido por este último a un gobernador, Anulino, que resulta ser el mismo que había sido el encargado de llevar a cabo la última persecución y al que no ha cambiado. Esto no resulta sorprendente, si tenemos en cuenta el panorama general, como no ha dejado 
de señalarse aunque Constantino juegue la carta del cristianismo, no hay rotura con el pasado. La importancia de las donaciones imperiales que se traducen en las grandes basílicas romanas constantinianas y en nuevos itinerarios de piedad no puede pasar por alto. Incluso en Tierra Santa estos nuevos itinerarios substituyen a las grandes peregrinaciones paganas orientales como las que se hacían al Asclepieion de Pérgamo. La represión de la haruspicina privada que se produce desde Constantino podría ser sintomática, aunque no podemos olvidar que incluso en este caso tenemos antecedentes anteriores muy antiguos.

Constantino propició seguramente un estado de cosas, en el que a pesar de su protección indudable a los cristianos, pudo dar orígen mucho más tarde a críticas de caracter ético y político como la contenida en los Césares, una sátira compuesta por Juliano, en la que intenta evidenciar la ficción de la conversión del emperador.

El lenguaje imperial y oficial, también como lo recoge Eusebio, está cargado de imprecisión buscada, se hablará de un Summus deus, de un Deus omnipotens, y los discursos-plegarias de Constantino estarán siempre vinculados a su propio poder, disfrazado de servicio. Eusebio pone en sus labios la palabra fé, y pone en evidencia la perseverante obediencia del emperador a la lex Augustissima y destaca su predestinación divina para unir el imperio.

En este clima de paz y tolerancia se llevarán a cabo los Concilios de Roma el 313 y de Arles el 314.

La legislación imperial continuará siendo dura, y naturalmente no muy cristiana, en temas como la esclavitud, los niños y el adulterio. En este punto hay que destacar un factor muy importante de la actuación de Constantino, que probablemente incide también con su continua intervención en las cuestiones cristianas: su disponibilidad en los casos de apelación al emperador contra jueces y gobernantes. El emperador pretende presentarse como la verdadera garantia de la felicidad del estado.

La relación de Constantino con Roma resulta muy extraña, la visitará en contadas ocasiones y preferirá sedes diversa y alejadas como Tréveris y Serdica, alejadas de la antigua capital del Imperio pero mucho más cercanas a sus intereses estratégicos y geo-políticos.

Las influencias que se pudieron ejercer sobre este emperador quedan en la sombra: se ha insistido mucho sobre el papel e influencia de Osio de Córdoba sobre Constantino, atribuída ya al 312 por algunos, pero segura, 
como veremos, desde el "phasma" de 326. Las mujeres de la casa imperial han sido objeto también de todo tipo de especualciones en especial Helena, y se ha supuesto o sospechado un acuerdo con Osio.

En este ambiente se llega a los decennalia del 315, momento en el que se hace al emperador la dedicación del arco que leva su nombre con motivo de su segunda visita a Roma con este motivo celebrativo.

En este caso es seguro que no subió al Capitolio, aunque en un principio la tradición y el protocolo lo hubieran previsto. Se trata de un claro rechazo al producirse un nuevo prodigio, un "phasma", atribuído por la tradición contraria al emperador a las malas artes de Osio. En realidad todo parece haber sido consentido a excepción de este acto, pero, como ha dicho con agudeza un especialista italiano: "senza fuoco e senza fumo", en otras palabras se pudieron realizar los actos tradicionales sin realización de sacrificios. De nuevo un punto de desencuentro entre el creciente cristianismo y la cultura pagana. La conversión de Constantino en este preciso momento no ha dejado de ser propuesta, pero sin duda, aunque con mejores elementos, carece de nuevo de argumentos probatorios definitivos, e incluso su movimiento de rechazo reviste un carácter casi supersticioso, como tampoco ha dejado de notarse.

El enfrentamiento inevitable con Licinio se produce en diversas etapas, en las que Constantino sea por medios militares que políticos y diplomáticos consigue limitar la influencia y territorio de su colega, y también cuñado. A continuación de la derrota de Licinio en el 317, dos de los hijos de Constantino, y Liciniano, hijo de Licinio, serán Césares en el colegio imperial, de corte todavía tetrárquico, emanado del nuevo pacto, y serán proclamados tales el 1 de marzo en Serdica.

La compleja personalidad de Licinio jugará en favor de Constantino y el aumento de las tensiones y provocaciones por ambas partes llevarán de nuevo a la guerra abierta, que culminará para Licinio el 3 de julio de 324 con la derrota de Hadrianopolis, y la de Chrysopolis el 8 de septiembre, en ambos casos Crispo será el brazo armado de su padre Constantino y sus victorias producirán la unificación del imperio en una sola mano, con lo que se llega a la culminación del proceso de deconstrucción del imperio tetrárquico perseguida por Constantino durante largos años.

En la propaganda cristiana será visto este enfrentamiento como una verdadera guerra de religión, como sucede en la biografía la de Eusebio. Es también el momento en que Helena será proclamada Augusta y parece que 
intervendrá a continuación decisivamente en algunos asuntos no siempre de carácter privado.

\section{Hacia la construcción de un nuevo imperio}

Nace seguramente en este momento el gran proyecto de una Constantinopolis, acorde con sus concepciones geo-políticas entre Oriente y Ocidente. En 324 se preocupa de nuevo de la tolerancia, pero esta vez con los paganos que sufren el crecimiento del cristianismo en Oriente.

Se muestra también a partir de este momento como el medius princeps en el concepto de Eutropio, frente al optimus princeps de la primera parte del reinado, diferencia que ha sido considerada como crucial clave de interpretación por estudiosos como V. Neri.

Los vicennalia del reinado se van a celebrar el 325 y 326 . Antes habrá tenido lugar un acontecimiento de gran significación, y no sólo para la historiografía cristiana: la participación activa del emperador en el concilio de Nicea en mayo y junio del 325. Su papel es crucial incluso en el ámbito dogmático, su busca del entendimiento continua y su papel mediador evitará problemas con el donatismo y el arrianismo, en un aplazamiento que tendrá sin embargo un amargo desenlace. El adventus al concilio del emperador, cubierto de oro y pedrerías, resulta, en palabras de Eusebio, casi sobrenatural; se sienta en un trono de oro, más pequeño que los sitiales de los obispos. Oye, opina y es escuchado. Nace aquí el tan traído y llevado concepto del Constantino obispo, y hay que matizar al respecto lo que él mismo parece haber precisado, en una línea muy suya de mediación: "epíscopos ton ektón”.

Los acontecimientos se van a precipitar acto seguido y van a comprometer en gran manera la imagen del emperador. En 325 había ordenado la ejecución de Licinio, con el pretexto, o razón, de que conspiraba para recuperar el imperio. La decisión de celebrar en el año 326 de nuevo el aniversario de su reinado, los vicennalia, en Roma es firme, pero antes de esta celebración se producirá la ejecución, en Pola, de su hijo Crispo y a continuación la muerte en un baño sobrecalentado de su mujer Fausta. Los motivos no son claros y van desde el adulterio entre hijastro y madrastra, el tema de Fedra e Hipólito, a ajustes de cuentas familiares por otros motivos, sin que pueda precisarse el papel de Helena, que algunos ven enfrentada a Fausta. La transformación del aula imperial de Tréveris en templo, quizás 
expiatorio, que causa la destrucción de los retratos entre los que incluso se ha querido ver a Lactancio, preceptor de Crispo, ha sido puesta en relación con estos hechos. Sean cuales sean los motivos, la humanidad del emperador queda en entredicho, por no hablar ya de sus posibles sentimientos cristianos: ha sido la reacción cruel y despiadada de un monarca de su tiempo. La damnatio memoriae de los dos ejecutados nunca será revocada. La muerte de su sobrino, e hijo de Licinio, Licinio Liciniano de sólo 11 años, en el 326, tendrá por objeto también evitar nuevas conspiraciones.

Su aparente tolerancia continuará en cambio en otros ámbitos y así, por ejemplo, el mismo calendario de Filocalo nos mostrará la pervivencia de los ludi. O bien se tolerará un cierto culto sin sacrificios a la dinastía en Hispellum, como forma de protección ciudadana.

La celebración de los vicennalia tiene lugar en esta última, por lo que parece, visita a Roma, siguiendo la pauta establecida ya en los decennalia. El cuidado y la preparación de la visita a Roma han sido grandes y las acunaciones de oro con la leyenda y la alegoría de la Gloria aeterna del senado y el pueblo romano lo documentan. Su actividad organizadora se despliega y multiplica, pero los recursos en el futuro se van a dedicar a su proyecto predilecto: la Nueva Roma, la ciudad que llevará su nombre. Helena es en el año 336 la única emperatriz y su estatua sedente con diadema hoy en el Vaticano ha sido relacionada con este momento.

Sólo en el 326 se decidirá a nombrar Constantino un alto cargo cristiano y este será el praefectus Urbis Romae Acilio Severo. La actividad del Constantino "obispo" continúa y el Viernes Santo del 328 pronuncia su discurso a la asamblea de los santos en el concilio de Nicomedia. Cada vez, sin embargo, resulta más clara su conciencia de la diversidad de Oriente y Occidente y de la necesidad de actuar por zonas. El cierre y expolio de templos paganos por parte de Constantino supone la pérdida de la autonomía cultural ciudadana y llena las arcas imperiales durante un largo período. La confiscación paulatina de bienes de los templos para la res privata, es otro de los elementos usados por el emperador para sus fines como ha puesto de relieve G. Bonamente.

La fundación de la Nova Roma tendrá lugar el 11 de mayo del 330. La voluntad no sólo de emulación o de duplicación de la antigua Roma por parte de Constantinopolis se evidencia en el translado ordenado por el emperador del Paladio, la reliquia fundacional romana, a su nueva capital. No vamos a entrar aquí en descripciones ni a discutir la dimensión de la misma, queremos 
sólamente poner de relieve que la nueva dinastía tiene allí el despliegue de un nuevo aparato acorde a la renovación llevada a cabo por su fundador.

La renovación, institucional y social, es profunda y el cristianismo juega en ello un papel de primer orden y se va estructurando y organizando dentro del marco del nuevo imperio. No faltan ejemplos de este tipo de substituciones, así la iglesia del Santo Sepulcro nace sobre el templo de Venus de Hadriano. Siguen los edificios de culto de Belén y del Monte de los Olivos. No hay duda que Helena está vinculada al nuevo itinerario de piedad que substituye el de los santuarios griegos paganos en Asia, así como la obra de Constantino en Roma constituye los nuevos mirabilia Urbis en este caso christiana. En un claro antecedente de la obra del papa Dámaso en Roma (366-384). Helena sólo será vinculada con la inventio crucis mucho más tarde, en 395, por Ambrosio de Milán, que no parece experimentar excesiva simpatía por la emperatriz, aunque hay que señalar también que ya se habían producido prodigios de aparición de cruces durante el reinado de Constancio II.

La situación política y económica se complica más y más y maniobras como la de 335 en que Hannibaliano es considerado en Armenia, rey de reyes, usando la ficción de los títulos persas, pone de relieve la dificultad de gobernar un imperio extenso con la ayuda sólo de pocos elementos familiares y en un clima de continua desconfianza. El gobierno de Constantino y sus empresas han dejado un imperio cambiado, en algunos aspectos renovado pero exhausto.

Los tricennalia de su reinado en 335 no se celebrarán ya en Roma, y en el curso de la celebración Eusebio de Cesarea pronunciará una oratio cargada de reminiscencias bíblicas elogiosas en la que intenta justificar la difusa política dinástica del emperador, que ha sumado al número de césares a su hijo menor Constante y a su sobrino Dalmacio, de esta cuádriga de príncipes se espera el cumplimiento de los designios del emperador y una armonía, que evidentemente ya se ve difícil, aunque se pretenda que Constantino reina en este momento tomando como modelo el gobierno celeste. En el mismo año inicia su campaña sarmática que intenta pacificar y ordenar de nuevo la zona danubiana, algo que conseguirá y celebrará, al menos oficialmente, en el año siguiente. Quedaba pues por resolver, entre enormes dificultades económicas, el problema persa, disponiéndose a hacerlo se aproximó el término definitivo de su largo reinado.

La muerte de Constantino se produce el 22 de mayo del 337 en Nicomedia (Izmit), y previamente había sido bautizado por Eusebio de 
Nicomedia, un obispo arriano. Es enterrado cristianamente en Constantinopla, en la iglesia de los 12 apóstoles. Su tumba, cambiada de lugar después por Constancio II, preside los cenotafios de los doce apóstoles. La cuestión, como no ha dejado de proponer últimamente A. Marcone, radica en que o bien es el decimotercero de los apóstoles, "isapóstolos", o bien pretende o se pretende que presida los cenotatafios como lo haría Cristo con sus discípulos.

Paralelamente, y en esto podemos ver de nuevo la corriente de continuidad tolerada y quizás también buscada y prevista por Constantino, se le hace una consecratio como divus en Roma.

En el mismo campo podemos inscribir la protección política del arrianismo a pesar de la condena de Nicea, un hecho evidente que continuará hasta el 376 con Teodosio. Los encomios cristianos presentarán, sin embargo, diciendo que reina a la derecha del hijo de Dios, al que en vida había rechazado el titulo de beatus.

La polémica sobre su bautismo tardío resulta poco productiva. Es un hecho sabido el bautismo al final de su vida y ya en peligro de muerte de los notables durante todo el período. Los hijos de Constantino mismo, educados cristianamente, son bautizados también tardíamente. Para explicar este hecho en el caso de los emperadores no basta pensar en el efecto purificador del bautismo, que limpia los actos de una vida, sino también el hecho de que el no bautizado no queda sujeto a la autoridad de un obispo, lo cual resulta de primordial interés en las relaciones con la Iglesia.

Los notables tienen dos vías de elección, su integración incorporándose a la jerarquía eclesiástica o bien el aplazamiento hasta el final, recordemos los cánones del concilio de Elbira del 373, sobre el ejercicio de sacerdocios paganos, para comprender cuál era la actitud, pero sin duda no es este el caso de los emperadores.

El ejemplo de Teodosio, bautizado antes de ser emperador por un peligro vital, es evidente y su problemática relación con Ambrosio de Milán una prueba muy clara.

En el verano siguiente a la muerte de Constantino se produce el asesinato político de Dalmacio y de Hannibaliano, de los descendientes no herederos de Constantino sólo sobrevivirá el futuro emperador Juliano. Las sospechas sobre Constancio II como instigador han sido a menudo expresadas y convierten esta cuestión casi en un hecho cercano a lo que iba a ocurrir posteriormente con los príncipes no herederos en el Imperio otomano. 
Precisar la verdadera conversión de Constantino es un hecho que, hoy por hoy, nos parece inalcanzable, en un ambiente complejo que mezcla paganismo, neoplatonismo y que conducirá a Mario Victorino al final del IV y también a Agustín de Hipona. Fírmico Materno llegará a decir en 340 que los cultos mistéricos son una parodia diabólica del cristianismo, mientras que el Sol como única divinidad es un avance indudable hacia el monoteísmo. Todavía en 342 Constancio II legislará contra la superstición y la adivinación, pero todo subsiste en el 359, cuando el prefecto de Roma todavía ordena sacrificar a Castor y Polux en un intento de paliar la llegada de grandes inundaciones. Nada podrá evitar además los contrastes y los cristianos continuarán apareciendo como bárbaros a los ojos de un Zósimo. En un ambiente de este tipo se mueve con una buscada, y quizás, indispensable ambigüedad un hombre como Constantino cuyas preferencias no obstante resultaron a todos evidentes.

\section{De qué situación partió Constantino y a cuál finamente llegó: la opinio recepta del Imperio cristiano}

Ya en el siglo XIX, A. Coen, un sagaz filólogo e historiador casi olvidado, definía con una cierta precisión no exenta de un excesivo positivismo lo que se creía que eran las intenciones de la tetrarquía:

1. Proveer a una defensa atenta, constante y eficaz del Imperio en relación a las agresiones externas.

2. Dar un nuevo cariz a la administración del Estado constituyendo sin ficciones ni más ambages una verdadera y propia monarquía.

3. Establecer una regla definitiva de sucesión en el trono.

Evidentemente contra esto se alza Constantino y pero no sólo para conculcarlo y cambiarlo sino para darle una nueva dimensión a la medida de sus propias ambiciones, y, lo que es más importante, para hacerlo con mayor adecuación a la realidad social de su momento. La dificultad de la aplicación de la idea de Diocleciano fue evidente; funcionó una sola vez por renuncia en vida de Diocleciano y Maximiano, y acto seguido fracasó cuando por una muerte se tuvo que producir una segunda sucesión. El autocratismo de la reforma dioclecianea pervive en la reforma de Constantino y la administración 
cobra definitivamente un nuevo sentido después de un cambio de estructura profundo en el cual desaparece por ejemplo el ordo equester y la estructura impositiva anterior. La vida de las ciudades se moverá también en otros parámetros y éste será un cambio visto por muchos como una crisis definitiva del modelo anterior y por consiguiente casi como la reducción o la desaparición de las comunidades cívicas. Todo esto es parcialmente cierto y responde a hechos indubitables, pero las ciudades no desaparecen, se reestructuran y tienen distinta organización y una vida por consiguiente también diferente. Las finalidades no son las mismas, la estructura política tampoco y la vida ciudadana tiene otros horizontes. El escenario antiguo no sirve ya, habia vivido precariamente casi un siglo y la ciudad se adapta a su nueva función. Se ha afirmado que el cristianismo tiene en este hecho un papel predominante, pero no es así en principio: el cristianismo se estructura jerarquiza y ordena precisamente en aquel momento y de acuerdo con el nuevo marco ciudadano y social, siendo como es un movimiento esencialmente urbano, es por tanto lógico que encuentre su lugar adecuado en este nuevo marco de comportamiento urbano, que después evidentemente contribuirá a propiciar como habitat natural para su expansión. La uniformidad del Imperio no existió nunca y la idea de Oriente y Occidente no es ninguna ficción ni un simple problema de expresión lingüística, hecho por otra parte nada indiferente a la diferencia. La articulación del sistema tetrárquico a pesar de su autoritarismo y su centralismo se muestra poco apropiada como solución política. Constantino sólo precipita los hechos.

La situación que deja Constantino a sus tres hijos no tiene, en principio, complicación dinástica y distingue perfectamente las zonas del Imperio. La tolerancia religiosa es un hecho y los cristianos estan integrandose con decisión en el nuevo panorama en la proporción de su realidad social por zonas. No se trata de un imperio cristiano, se trata de un imperio cuyos principios políticos, a pesar de algunas concesiones formales, se funda sobre un poder autocrático, evolucionado progresivamente desde los problemas del siglo III, a los que la tetrarquía había querido poner fin con su estructura. La disposición de Constantino quiere responder a estas mismas cuestiones, dejando fuera el menor número de ciudadanos o habitantes del Imperio. Los cristianos son ya de una entidad no ignorable y el realismo político supone integrarlos sin traumas, a sabiendas de que traen consigo un nuevo orden social que se superpondrá y en gran parte se adaptará al precedente. Esta es verdaderamente la herencia de Constantino, y no, como se ha querido ver, un 
imperio cristiano al que permitirá continuar por un tiempo, con su impulso renovado, el cristianismo emergente. La idea de poder, de estado, de imperio es la heredada de la tetrarquía; los cristianos no son ya un conflicto social, pero el cristianismo no por ello es una religión de estado. El estado se reconoce y se apoya en las estructuras cristianas que ha contribuido a consolidar y a organizar, pero aunque los emperadores sean ya cristianos, sus actuaciones responden más a la condición de emperador que a la de cristiano. Oriente se ha cristianizado rapidamente y Occidente se precipita a hacerlo a pesar de notorias resistencias y reacciones. El cristianismo, como captó ya muy bien el proprio Constantino, se muestra como una buena herramienta de cohesión, pero no está exento de problemas internos de una virulencia a veces poco esperable. De aquí la voluntad de situar al estado personificado por el emperador como árbitro y garante de una paz necesaria para la pervivencia del modelo de sociedad. En cierta manera Constantino y sus sucesores se sitúan como emperadores por encima de la estructura religiosa a la cual pertenecen y sobre la cual irán contando más y más. La legislación lo deja claro y las actuaciones imperiales más todavía. Los centros de poder se han desplazado: el control del Imperio se debe hacer a las puertas de Oriente. Roma es ya más una idea que una ciudad y esto entraña problemas que no consigue resolver a gusto de todos la Iglesia. La distribución de Constantino es una solución dinástica más que una partición del Imperio, como los acontecimientos inmediatamente posteriores se encargarán de no desmentir. No es una solución ni perfecta ni definitiva, pero resuelve los problemas de la irrealizable solución tetrárquica y tiene la pretensión de integrar al mayor número posible de habitantes del Imperio en unos parámetros comunes de conducta factibles para todos. Una solución en el fondo pragmática adecuada a un momento histórico y a unas circunstancias personales y familiares. Se ha impuesto una vez más la solución posible sin que podamos pretender, hoy por hoy, saber cual hubiera sido la mejor.

\section{La fama póstuma}

S. Calderone ha mantenido que Constantino es un hombre de su tiempo y no un libre pensador ni un astuto convertido por interés al cristianismo. Se convierte, en su opinión, como hombre simple y como estadista consciente.

Se trata evidentemente como expresa en tan benévola, como justificada definición, de un hombre de su tiempo y como hombre de su tiempo le 
juzgaron los historiadores antiguos. Algunos como Eutropio ven en él y en sus ejecuciones y crímenes casi un Nerón y en la segunda parte de su reinado un emperador mediocre. Otros como Eusebio de Cesarea componen obras cuyo título no deja lugar a engaños, "eis ton bíon tou makariou Konstantínou Basiléos". Eusebio, que conoce a Constantino pues asiste a Nicea, pretende en su biografía, al parecer no revisada y dejada inacabada a su muerte en 339, hacer lo que, según T. Barnes, puede ser definido como un experimento de hagiografía, hipótesis que ha aceptado P. Brown. Zósimo en cambio, que deriva de Eunapio, deja traslucir un odio feroz hacia la figura del emperador y manifiesta que Constantino a partir del 326 no pone freno a su mala índole, que aumenta por la impulsividad de su carácter y la influencia nefasta de su entorno en especial de Sópatro. Más moderado parece en este caso Eutropio que se limita a destacar como causa de su actuación la ambición desmedida que lo domina. En último término Lactancio en su De mortibus persecutorum, obra sin duda tendenciosa, aparecerá como el más aséptico y objetivo a causa de su moderación. Los historiadores posteriores como Sócrates o Sozomeno tendrán también un "parti pris". Nadie, pues, queda indiferente y una vez más la historia o en este caso, para nosotros, las fuentes historiográficas se convierten en una opinión. La idea de un "Constantinus orthodoxus", después de la condena de que es objeto por parte de san Jerónimo, es producto de la rehabilitación llevada a cabo por san Ambrosio y por Rufino; incluso, como puede comprobarse, entre los autores cristianos la diversidad de opiniones fue notable.

Recientemente se ha estudiado de nuevo la iconografía de sus acuñaciones en las que la crueldad, compañera del poder, que tiene por arma el terror, en aquel momento está presente con temas como la muerte de enemigos suplicantes; es evidente en ella lo que P. Zanker ha definido como "imágenes de violencia” y que es típica, por lo demás, de las demostraciones de fuerza que entra en parámetros políticos de su tiempo.

La teorización presente en los discursos de Constantino, recogidos por Eusebio, en una fiabilidad de la que hoy nadie parece dudar, es definida por A. Alföldi como una cierta "conciencia misionera", que sin duda para ser objetivos hay que matizar que está cargada de intereses politicos. Intereses que forzarán más tarde nuevas interpretaciones para justificar el nacimiento de una teología cristiana del poder ya en aquel momento.

La conversión de Constantino ha forjado, ya desde la propia antigüedad, todo tipo de interpretaciones, algunas de ellas tan hostiles al cristianismo como 
las que afirman que el perdón cristiano es el único posible para los crímenes de Constantino. Las leyendas vinculadas al papa Silvestre sobre la lepra del emperador y su curación se mueven en este medio. No es este el momento de adentrarnos en ellas, pero hay que decir que contienen una carga de elementos conocidos también en otras fuentes y en relación a otros personajes, los Actus beati Silvestri, tienen fuentes hoy bien conocidas. El famoso constitutum Constantini o "donación constantiniana", sería la consecuencia del agradecimiento del emperador y justificaría los derechos de la Iglesia sobre la península itálica y sobre la propia ciudad de Roma. Es curioso observar como la cuestión pervive hasta los Pactos Lateranenses.

Nace de aquí una cuestión, derivada evidentemente de un falso histórico, cuyos textos fudamentales datan del siglo IV o V, contrastado, pero de una enjundia política que la lleva a sobrevivir a través de los siglos.

Ya el emperador Otón y su preceptor Gerberto de Aurillac, papa con el nombre simbólico de Silvestre II, en los albores del año mil insistieron, con escaso resultado político, en la no legitimidad de la leyenda y de los documentos que la sustentan.

La leyenda con aspectos negativos contenida en el De ortu Constantini eiusque matre Helena libellus, quizás del siglo XI en su versión latina, es como ha demostrado J.-P. Callu propiamente una novela y encrucijada de numerosas tradiciones anteriores sobre el tema que se entremezclan en ella. Otras vidas de Constantino nos son conocidas durante el medioevo, algunas de ellas mucho más antiguas como el llamado Anonymus Valesianus, de inapreciable valor. La tradición gálica representada por las Chroniques des comtes d'Anjou, de los siglos X-XII, es una buena muestra de esta continuidad.

La Leyenda áurea de Jacobo de Vorágine contribuye en el siglo XIII a consolidar la parte positiva para la Iglesia. En el "Trecento" se opone a esta leyenda Marsilio de Padua. La donación estará presente también, con tono crítico, en la Divina Comedia de Dante.

El peso de esta tradición es tan importante que incluso un Eneas Silvio Piccolomini, papa con el nombre de Pío II, en su disputa con el emperador Federico II, llega a proponer al sultán Mohamed II, la conversión al cristianismo para rehacer de nuevo el imperio constantiniano.

En el período humanístico, con los avatares políticos y las ambiciones extranjeras sobre Italia, cobran nueva actualidad, Maquiavelo y Lorenzo Valla se esfuerzan en demostrar su falsedad. Alejandro VI con su proverbial 
pragmatismo, no para mientes en la cuestión que utiliza a su conveniencia, consciente de su precariedad.

Mientras la Iglesia oriental considera a Constantino santo, un verdadero "isapóstolo" que sitúa junto a san Pablo. Se trata de un Constantino "soter" en el sentido pleno de la palabra.

Si Constantino entra en la cultura de caballerías medieval, como la materia de Bretaña, y se representa como caballero en la decoración escultórica de muchas iglesias francesas: los "constantins". En el renacimiento su visión positiva lo transformará casi en un "espejo de príncipes cristianos", en quien primero captó y supo hacer trascender la importancia de "los dos poderes del mundo".

S. Mazzarino con gran sagacidad ha podido identificar los inicios y las raíces del movimiento histórico anticonstantiniano que encabeza la obra de J. Burckhardt en el pietismo centroeuropeo de los siglos XVII y XVIII, que no admite la diferencia que se constata entre la fé cristiana atribuida a Constantino y sus actos.

Entre encomio, apología o amarga crítica se desenvuelve la biografía y la memoria de aquel a quien el proprio S. Mazzarino no duda en calificar como: "il grande rivoluzionario della storia romana" o "l'uomo politico più rivoluzionario della storia d'Europa", una figura histórica ante la cual, como hemos dicho ya al inicio de nuestro trabajo, no puede quedar nadie indiferente. Un hito que no se puede obviar en un tema como la construcción de la idea de Europa, de un diálogo entre las diversas riberas del Mediterráneo, en suma en el momento de estudiar lo que constituyó en gran parte el territorio de un Imperio, de cuyos puntos débiles y de cuyas zonas de fricción la historia nos demuestra que fue un profundo conocedor. 


\section{Nota bibliográfica}

Algunas obras generales sobre la Antigüedad tardía pueden resultar importantes para encuadrar el tema: O. Seeck, Geschichte des Untergangs der antiken Welt, 6 vols, Stuttgart 1920-1923, (reimpr. 1966); E. Stein, J. R. Palanque, Histoire du Bas Empire, I, Paris, Brujas 1968, (es una reimpr. de la ed. en francés de 1959, versión aumentada de la ed. en alemán de E. Stein de Viena 1928); A. Chastagnol, Le Bas-Empire, París 1991'; H. Brandt, Geschichte der römischer Kaiserzeit. Von Diokletian und Konstantin bis zum Ende der konstantinische Dynastie (264-363), Berlín 1998; H. Brandt, L'epoca tardo antica, Bolonia 2005 (trad. de la ed. alemana, Munich 2001); A. Chastagnol, L'évolution politique, sociale et économique du monde romain de Diocletien a Julien (284-363), París 1982; J. Straub, Vom Henrscherideal in des Spätantike, Stuttgart 1939; A. Demandt, A. Goltz y H. Schlange-Schöningen eds., Diokletian und die Tetrauchie. Aspekte einer Zeitenwende, Berlín, Nueva York 2004, especialmente el trabajo de F. Kolb, "Praesens Deus: Kaiser und Gott unter der Tetrarchie", p.27-37; A. Demandt, Die Spätantike. Römische Geschichte von Diokletian bis Justinian, Munich 1989; A. H. M. Jones, The Later Roman Empire (284-602). A Social, Economic and Administrative Survey, Oxford 1964; P. Brown, The Making of Late Antiquity, Cambridge, Mass., Londres 1978; A. Cameron, The Later Roman Empire, Londres 1993; R. MacMullen, Corruption and Decline of Rome, New Haven, Londres 1988; F. Heim, Virtus. Idéologie politique et croyances religieuses au IV siècle, Berna, Frankfurt a. M., Nueva York 1991; S. Mazzarino, II basso impero. Antico, tardoantico ed era costantiniana, Bari 2003 (reimpr. de la ed. de 1974); D. Vera ed., La società del Basso Impero. Guida storica e critica, Roma, Bari 1993; F. Millar, The Emperor in the Roman World (31 BC-AD337), Londres 1977. J. Harries, Law and Empire in late antiquity, Cambridge 1999.

Para las usurpaciones y el concepto de tyrannus cf. M. Dimano, Zonaras' account of the Neo-Flavian Emperors: A commentary, Columbia, Miss. 1977, en especial para el concepto que aquí nos interesa, p.131; St. Elbern, Usurpationen im spätrömischen Reich, Frankfurt a. M., 1984 .

La cristianización del imperio es tratada en: P. Brown, Power and Persuasion in Late Antiquity. Towards a Christian Empire, Londres, Madison 1992; A. Lotz, Der Magiekonflikt in der Spätantike, Bonn 2005; B. Brenk, Spätantike und frühes Christentum, Frankfurt a. M., Berlín, Viena 1977; R. MacMullen, Christianizing the Roman Empire (A. D. 100-400), New Haven, Londres 1984; A. Marcone, "La politica religiosa: dall'ultima persecuzione alla toleranza" en A. Schiavone ed. Storia di Roma, III, L'età tardoantica, I, Crisi e trasformazioni, Turín 1993, p.223-24.5; G. Bonamente, A. Nestori eds., I cristiani e l'impero nel IV secolo. Colloquio sul cristianesimo nel mondo antico, Macerata 1988; P. de Labriolle, La reaction paienne, París 1934, es todo un clásico sobre el tema; A. Piganiol, L'empire chrétien, París 1972² M. Sordi, I cristiani e l'impero romano, Milán 1984; A. Saggioro ed., Diritto romano e identità cristiana. Definizioni storico-religiose e confionti interdisciplinari, Roma 2005; P. Siniscalco, Il cammino di Cristo nell'Impero romano, Roma, Bari 2004.

Las fuentes principales sobre Constantino: L. Tartaglia ed., Eusebio di Cesarea. Sulla vita di Costantino, Nápoles 2001² Ch. E. V. Nixon, B. S. Rodgers, Panegyrici Latini. In praise of Later Emperors, Berkeley, Oxford 1994; F. Paschoud ed., Zosime: Histoire nouvelle, 5 vols., París 1971-1989; I. König ed., Origo Constantini. Anonymus Valesianus, vol. I, Tréveris 1987; L. Duchesne ed., Le Liber Pontificalis, 2 vols., París 1886-1892 (reimpr. París 1981, con un 
tercer volumen de suplementos e índices); V. Aiello, "Cassiodoro e la tradizione su Costantino" en S. Leanza ed., Cassiodoro. Dalla corte di Ravenna al Vivarium di Squillace. Atti del Convegno internazionale di Studi. Squillace 25-27 ottobre 1990, Mesina 1994, p.133-157; T. D. Barnes, Constantine and Euscbius, Cambridge, Mass. 1981; O. Seeck, "Die Urkunden der Vita Constantinl", $Z K G, 18,1898$, p.321-345; T. D. Barnes, "Lactantius and Constantine", JRS, 63, 1973, p.29-46; M. Franzi, "La propaganda costantiniana e le teorie di legittimazione del potere nei Pancgyrici Latinl", AAT, 115, 1981, p.25-37; R. Teja ed., Lactancio, Sobre la muerte de los perseguidores, Madrid 1981. Es de una gran utilidad no sólo para este campo: V. Neri, Medius princeps. Storia e immagine di Costantino nella storiografia latina pagana, Bolonia 1992. Es ahora muy importante para los precedentes A. Mirkovic, Prelude to Constantine. The Abgas Tradition in Early Christianity, Frankfurt a. M., Berlín, Berna, Bruselas, Nueva York, Oxford, Viena 2004, (Arbeiten zur Religion und Geschichte des Urchristentums, 15).

Las monografías sobre Constantino son muy numerosas y una selección resulta casi imposible, no obstante hemos procurado recoger algunas de las más importantes y también otras que son representativas de tendencias particulares: J. Burckhardt, Die Zeit Constantins des Grossen, Leipzig $1880^{2}$ (1ed, 1852), es el punto de partida crítico de los estudios modemos; A. Piganiol, L'empereur Constantin, París 1932; K. Hönn, Konstantin der Grosse, Leipzig 1940; H. Dörries, Das Selbstzeugnis Kaisers Konstantins, Gotinga 1954; J. Vogt, Konstantin der Grosse und sein Jahrhundert, Munich 1962; H. Dörries, Konstantin der Grosse, Stuttgart 1958² H. Kraft ed., Konstantin der Grosse, Darmstadt 1974; R. MacMullen, Constantine, Londres 1987. Resulta de capital importancia el coloquio sobre Constantino que tuvo lugar en Macerata en 1990 para la renovación del pensamiento sobre un buen número de cuestiones constantinianas: G. Bonamente, E. Fusco eds., Costantino il Grande dall'Antichità all'Umanesimo. Colloquio sul Cristianesimo nel mondo antico, Macerata 18-20 Dicembre 1990, Macerata 1992-1993 (= Costantino il Grande). B. Bleckmann, Konstantin der Grosse, Hamburgo 1996; M. Clauss, Konstantin der Grosse und seine Zeit, Munich 1996; A. Marcone, Costantino il Grande, Roma, Bari 2000; A. Marcone, Pagano e cristiano. Vita e mito di Costantino, Roma, Bari 2002. Otros trabajos consultables son: T. Somigli di S. Detale, Costantino il Grande e il Problema Politico-Religioso al principio del Secolo IV (274-337), Florencia 1913, una muestra de una posición confesional; F. Stampoli, Costantino il Grande e la sua dinastia. Amori, tradimenti, rivalità, guerre, massacri e lotte fratricide della prima "gens" cristiana nella storia del potere, che segna l'inizio della decadenza dell'mpero, Roma 2003², con un componente divulgativo. Una muy importante y práctica puesta a punto de las cuestiones puede encontrarse en el recientísimo catálogo de la exposición celebrada en Rimini: A. Donati, G. Gentili eds., Costantimo il Grande. La civiltà antica al bivio tra Occidente e Oriente, Cinisello Balsamo, Milano 2005, que contiene toda una serie de artículos del más alto valor a cargo de notables especialistas. La variedad de puntos de vista ha merecido en los últimos tiempos la aparición del trabajo de Tr. Heinze, Konstantin der Grosse und das konstantinische Zeitalter in den Urteilen und Wegen der deutsch-italienischen Forschungsdiskussion, Munich 2005, (Quellen und Forschungen zur Antiken Welt, Band 45), que hace un cuidadoso análisis del pensamiento de los principales estudiosos.

Es muy útil para el estudio de Constantino la visión bibliográficamente al día sobre las cuestiones que suscita el estudio de la Tetrarquía en W. Kuhoff, Diokletian und die Epoche der Tetrarchie, Frankfurt a. M. 2001, como aspecto especial queremos destacar el cuidado en el tratamiento de la actuación de Majencio, esp. p.802-825 y p.882-913, para la batalla con 
Constantino a las puertas de Roma; W. Seston, Dioclétien et la Tetrarchie, París 1947; A. Coen, L'abdicazione di Dicleziano, Livorno 1877. Es interesante consultar para Constancio Cloro y su relación con Claudio II el Gótico tres trabajos de A. Lippold, "Constantius Caesar, Sieger über die Germanen, Nachfahre des Claudius Gothicus? Der Panegyricus von 297 und die Vita Claudii der HA", Chiron, 11, 1981, p.347-369, "Kaiser Claudius II (Gothicus), Vorfahr Konstantins d. Gr. und der römische Senat", Klio, 74, 1992, p.380-394 y "Claudius, Constantius, Constantinus. Die Vita Claudii der HA. Ein Beitrag zur Legitimerung der Herrschaft. Konstantin aus stadtrömischer Sicht", en G. Bonamente ed., Historiae Augustae Colloquium Perusimum, Bari 2002, p.309-343; A. Baldini, "Claudio il Gotico e Costantino in Aurelio Vittore ed Epitome de Caesaribus", en Costantino il Grande, p.73-89. Para Maximiano: A. Pasqualini, Massimiano Herculius. Per una interpretazione della figura e dell'opera, Roma 1979; y para Majencio: M. Cullhed, Conservator Urbis suae. Studies in the Politics and Propaganda of the Emperor Maxentius, Estocolmo 1994; Y. Duval, "Les Gesta apud Zenophilum et la "Paix de Maxence" (Gesta I0 226)", AntTard, 3, 1995, p.55-63. Sobre los equites singulares pueden consultarse los trabajos de M. P. Speidel, "Maxentius and his equites singulares in the battle at Milvian bridge", ClAnt, 5, 1986, p.253-259, "Les prétoriens de Maxence. Les cohortes palatines romaines”, MEFRA, 100, 1988, p.183-186, Dic Denkmäler der Kaiserreiter: Equites singulares Augusti, Colonia 1994. (Beihefte der BJ, 50), Riding for Caesar: The roman emperor horseguards, Londres 1994. El caso de Licinio: F. Corsaro, "L'imperatore Licinio e la legislazione filocristiana dal 311 al 313", Studi in onore di Cesare Sanfilippo, vol. III, Milán 1983, p.157-186; A. Arnaldi, "Osservazzioni sul convegno di Cannuntum", MIL, 35,1975, p.217-238; A. Chastagnol, "Quelques mises au point autour de l'empereur Licinius" en Costantino il Grande, p.310-323; W. Seston, "La conférence de Carnuntum et le dies imperü de Licinius", en Carnuntina. Römische Forschungen in Niederösterreich, vol. 3, Graz, Colonia 1956, p.175-186. Véanse un buen grupo de estudios constantinianos en W. Seston, Scripta varia. Mélanges d'histoire romaine, de droit, d'épigraphie et d'histoire du Christianisme, Roma 1980. Para las cuestiones que ligan a Diocleciano y Constantino: T. D. Barnes, The New Empire of Diocletianus and Constantine, Cambridge, Mass., Londres 1982; N. H. Baynes, "Three Notes on the Reforms of Diocletian and Constantine", JRS, 15, 1925, p.195-208; N. Baglivi, "Da Diocleziano a Costantino: un punto di riferimento "storiografico" in alcune interpretazioni tardoantiche", Orpheus, 12, 1991, p.429-491 y en Costantino il Grande, p.59-72.

El tema de la conversión y del imperio cristiano de Constantino y su relación con el paganismo es el objeto de muchos estudios: F. Paschoud, "Zosime 2, 29 et la version païenne de la conversion de Constantin", Historia, 20, 1971, p.334-353; J. Moreau, "Sur la vision de Constantin (312)", REA, 55, 1953, p.307-333; F. Paschoud, "Ancora sul rifiuto di Costantino di salire al Campidoglio" en Costantino il Grande, p.737-748; A. Fraschetti, "Costantino e l'abbandono del Campidoglio" en A. Giardina ed., Società ronana e impero taudoantico, vol. II, Bari 1986, p.59-98; P. Batiffol, La paix constantinienne et le catholicisme, París 1914; N. H. Baynes, Constantine the Great and the Christian Church, Londres 1931; A. Fraschetti, La conversione. Da Roma pagana a Roma cristiana, Roma, Bari 1999; S. Calderone, "Letteratura costantiniana e "conversione" di Costantino" en Costantino il Grande, p.231-252; L. De Giovanni, L'imperatore Costantino e il mondo pagano, Nápoles 2003; F. Heim, La théologie de la victoire de Constantin à Théodose, París 1992; A. Momigliano ed., Il conflitto tra paganesimo e cristianesimo nel IV secolo, Turín $1971^{2}$ (trad. it. de la ed. de Oxford 1963); 
J. Bleicken, Constantin der Grosse und die Christen. Überlegungen zur constantinischen Wende, Munich 1992; A.H. M. Jones, Constantine and the Conversion of Europe, Londres 1964; Ch. M. Odahl, Constantine and the christian Empire, Londres, Nueva York 2004; T. G. Elliot, The Chnistianity of Constantine the Great, Scranton 1996; A. Alföldi, The Conversion of Constantine and Pagan Rome, Oxford 1948 (trad. it. Costantino tra paganesimo e cristianesimo, Roma, Bari 1976); H. C. Kee, Constantine versus Christ. The Triumph of Ideology, Londres 1982; H. Kraft, Kaiser Konstantins religiöse Entwicklung, Tubinga 1955; S. Calderone, Costantino e il cattolicesimo, I, Florencia 1962; E. Schwartz, Kaiser Konstantin und die chnistliche Kirche, Leipzig, Berlín 1936²; P. Keresztes, Constantine, a Great Christian Monarch and Apostle, Amsterdam 1981; F. Bajo, "La quaestio constantiniana (I)", HAnt, 13, 1986-1989, p.173-188; V. Cicala, "Optimus princeps rerum humanarum. Ideologia imperiale ed ottica cristiana nella propaganda politica costantiniana", RSA, 16, 1986, p.183-187; J. Gaudemet, "La législation religieuse de Constantin", Revue d'Hist.de l'Eglise de France, 33, 194.7, p.25-61; F. Corsaro, "La pace religiosa nella "Realpolitik" costantiniana", QC, 10, 1988, p.221-237. Un buen análisis reciente: M. Amerise, Il battesimo di Costantino il Grande. Storia di una scomoda eredità, Stuttgart 2005 (Hermes. Einzelschriften, Heft 95).

Para aspectos parciales tratados en nuestro trabajo además de algunos citados en los apartados anteriores son importantes: J. Straub, "Konstantins Verzicht auf den Gang zum Kapitol”, Historia, 4, 1955, p.297-313; Los estudios de J. Straub están recogidos en Regeneratio impenï. Aufsätze über Roms Kaisertum und Reich inn Spiegel der heidnischen und christlichen Publizistik, 2 vols., Darmstadt 1972; B. Saylor-Rodgers, "Constantine's Pagan Vision", Byzantion, 50, 1980, p.259-278; W. Seston, "La vision paienne de 310 et les origines du chrisme constantinien", en Mélanges Franz Cumont, Bruselas 1936, p.373-388; B. Bleckmann, "Pagane Visionen Konstantins in der Chronik des Johannes Zonaras", en Costantino il Grande, p.151-170; G. Bonamente, "Eusebio, Storia ecclesiastica IX, 9 e la versione cristiana el trionfo di Costantino nel 312", en L. Gasperini ed., Scritti sul mondo antico in memoria di Fulvio Grosso, Roma 1981, p.55-76; M. Di Maio, J. Zeuge, N. Zotov, “Ambiguitas constantiniana. The caeleste signum Dei of Constantine the Great”, Byzantion, 58, 1988, p.333-360; G. PuglieseCarratelli, "L'imitatio Alexandri costantiniana", FR, 118, 1979, p.81-91; G. Marasco, "Costantino e le uccisioni di Crispo e Fausta (326 d. C.)”, RFIC, 121, 1993, p.297-317; G. Bonamente, "Sulla confisca dei beni mobili dei templi in epoca costantiniana" en Costantino il Grande, pp.171-201. Para el llamado "edicto de Milán": O. Seeck, "Das sogenannte Edikt von Mailand", ZKG, 12, 1891, p.381-386; T. Christiansen, "The so-called Edict of Milan", C\&M, 25, 1984, p.129-175. Sobre Osio de Córdoba: V. C. De Clercq, Ossius of Cordova. A Contribution to the History of the Constantinian Period, Washington 1954; H. Chadwick, "Ossius of Cordova and the Presidency of the Council of Antioch, 325" JThS, 9,1958, p.292-304; A. Lippold, "Bischof Ossius von Cordova und Konstantin der Grosse", ZKG, 92, 1981, p.1-15; J. Fernández Ubiña, "Osio de Córdoba, el Imperio y la Iglesia del siglo IV", Gerión, 18, 2000, p.439-4.73.

Para el arte $\mathrm{y}$ las representaciones constantinianas, especialmente el arco: $\mathrm{R}$. Krautheimer, "The Ecclesiastical Building Policy of Constantine" en Costantino il Grande, p.509-552 y Aichitettura sacra paleocristiana e medievale e altri saggi su Rinascimento e Barocco, Turín 1993 (trad. de la ed. alemana con el título Ausgewählte Aufsätze zur europäischen Kunstgeschichte, Colonia 1988); H. Brandenburg, Roms frühchristliche Basiliken des 4. Jahrhunderts, Munich 1979; P. Zanker, Un'ate per l'impero. Funzione ed intenzione 
delle immagini nel mondo romano, Milán 2002, una recopilación de trabajos cuidada por E. Polito entre los cuales conviene destacar para nuestro objeto: "I barbari, l'imperatore e l'arena. Immagini di violenza nell'arte romana”, p.38-62; M. Weder, Constantinische Deckengemälde aus dem römischen Palast unter dem Trierer Don, Tréveris 1990². Es fundamental ahora: H. Brandenburg, Le prime chiese di Roma IV-VII secolo. L'inizio dell'architettura ecclesiastica occidentale, Milán 2004. (trad. de la ed. alemana del mismo año). Sobre la zona de la domus Faustac: P. Liverani, "Le proprietà private nell'area lateranense lino all'età di Costantino", MEFRA, 100, 1988, p.891-915 y "Note di topografia lateranense: le strutture di via Amba Aradam. A proposito di una recente pubblicazione”, Bull. Comm. Arch Com. di Roma, 95, 1993, p.143-152. Para el arco: H.-P. L’Orange, A. von Gerkan, Der spätrönische Bildschmuck des Konstantinsbogens, Berlín 1939; A. Giuliano, Laarco di Costantino, Milán 1956; A. Cassatella, M. L. Conforto, L'arco di Costantino. Il restauro della sommità, Pesaro 1989; P. Barceló, "Una nuova interpretazione dell'arco di Costantino", en Costantino il Grande, p.105-114; C. Panella ed., Meta Sudans I, Roma 1996; P. Pensabene, C. Panella eds., Arco di Costantino. Tra archeologia e archeometria, Roma 1999; M. L. Conforto et alï, Adriano e Costantino. Le due fasi dell'arco nella valle del Colosseo, Milán 2001. Para Constantinopolis: C. Bersanti, "Costantinopoli: testimonianze archeologiche di età costantiniana", en Costantino il Grande, p.115-150. La numismática es estudiada por ejemplo por P. Bruun, Studies in Constantinian Numismatics. Papers from 1954 to 1988, Roma 1991 (Acta Instituti Romani Finlandiae, vol. XII) y más recientemente por F. López Sánchez, Victoria Augusti. La representación del poder del emperador en los reversos monetales romanos de bronce del siglo IV d. C., Zaragoza 2004.

Para las leyendas y la tradición posterior: V. Aiello, "Costantino, la lebbra e il battesimo di Silvestro", en Costantino il Grande, p.17-58; V. Aiello, "Aspetti del mito di Costantino in occidente. Dalla celebrazione agiografica alla esaltazione epica”, AFLM, 21, 1988, p.87-116; L. Cracco Ruggini, "Costante II, l'anticostantino" en L. Gasperini ed., Scritti sul mondo antico, p.543-559; W. Kaegi, "Vom Nachleben Konstantins" Schweizerische Zeitung für Geschichte, 8, 1958, p.289-326; G. Bonamente, "Sull'ortodossia di Costantino. Gli Actus Sylvestri dall'invenzione all'autenticazione", Bizantinistica. Rivista di Studi Bizantini e Slavi, VI, 2004, p.1-46; M. Pliuchanova, "Il culto di Costantino il Grande nella Russia antica", ibidem, p.191215; J.-P. Callu, "Ortus Constantini: Aspects historiques de la légende" en Costantino il Grande, p.253-282; M. Mazza, "Costantino nella storiografia ecclesiastica (dopo Eusebio)", en Costantino il Grande, p.659-692; G. Marasco, "Giuliano e la tradizione pagana sulla conversione di Costantino", RFIC, 122, 1994, p.34.0-354; G. M. Vian, La donazione di Costantino, Bolonia 2004. G. Crifò, "Su alcuni abusi del "Costantinianesimo"”, cn Costantino il Grande, p.347-356; L. Cracco Ruggini, "Tradizione romana e tradizione gallica su Costantino nelle Chroniques des contes d'Anjou", en ibidem, p.325-346; M. Accame Lanzillotta, "La memoria di Costantino nelle descrizioni di Roma medioevali e umanistiche", ibidem, p.7-16; L. Banfi, "Costantino in Dante", ibidem, p.91-103; R. Fubini, "Contestazioni quattrocentesche della donazione di Costantino: Niccolò Cusano, Lorenzo Valla”, ibidem, p.385-431; J. Irmscher, "L'imperatore Costantino nel giudizio dei riformatori tedeschi", ibidem, p.487-4.93; L. Braccesi, "Costantino e i Patti lateranensi”, ibidem, p.204-211. 
LEGISLAZIONE E GIURISDIZIONE NEL DIRITTO GRECO E ROMANO

\author{
Alberto Maffi \\ (Università di Milano-Bicocca)
}

1. Erano molti i temi relativi all'organizzazione politica e giuridica antica che si prestavano ad essere trattati alla luce delle norme della Costituzione europea, che, come è noto, ha subito una battuta d'arresto (speriamo soltanto temporanea). Ad es. le tematiche contenute nel capo IV: spazio di libertà, sicurezza e giustizia (artt. 257 ss.), soprattutto con riferimento alla sezione II: "politiche relative ai controlli alla frontiera, all'asilo e all'immigrazione" (artt. 265-268); oppure le norme relative alla cooperazione giudiziaria in materia civile e penale. Il progetto di Costituzione europea, tuttavia, non si poneva in modo esplicito l'obiettivo di creare un diritto comune europeo; si limitava a prevedere la possibilità di approvare "misure di armonizzazione" fra le norme dei diversi paesi (ad es. nell'art. 271 n. 2). Ma il problema della creazione di un diritto comune europeo deve essere posto prima di tutto come un problema storico: non si può pensare a un diritto europeo che non rispecchi la lunga storia del diritto dei vari paesi europei, le cui radici affondano nei diritti dell'antichità, prima di tutto romano, ma anche, soprattutto per quanto attiene alle strutture costituzionali, greco. Qui vorrei esaminare molto sommariamente le radici antiche di un principio che rappresenta un pilastro degli ordinamenti giuridici europei, cioè che $\mathrm{i}$ giudici sono tenuti a pronunciare le loro sentenze in conformità alle leggi. 
2. Gli ordinamenti giuridici moderni attribuiscono ai giudici il compito di risolvere le controversie sulla base delle leggi (è compito specifico della Corte di Cassazione, istituita dall'art. 19 del Capitolo V della Costituzione francese del 1791, verificare che i giudici dei tribunali emettano le loro sentenze in conformità alle leggi vigenti). Nei codici di procedura civile (Disposizioni di attuazione art. 118) e penale (artt. 426 e 546), vigenti attualmente in Italia, si stabilisce che la sentenza deve contenere l'indicazione delle norme di legge applicate.

L'obbligo per i giudici di conformare la loro sentenza alle leggi lo troviamo già chiaramente formulato nel mondo greco, e in particolare nel giuramento richiesto ai giudici del tribunale popolare ateniese nel IV sec. a.C. (Dem. c. Timocr. 149-51; c. Lept. 118, c. Aristocr. 96, c. Boeot. II, 40, 41).

Si può pensare che questo vincolo a giudicare in base alla legge fosse una caratteristica peculiare alla democrazia ateniese, anche se si tratta di un principio che troviamo sporadicamente affermato anche in altre poleis greche. Ma occorre tenere conto che questo principio viene affermato in un contesto molto diverso da quello dello Stato moderno. Sappiamo infatti che nel mondo greco, ma anche nel mondo romano, i giudici non hanno una specifica preparazione giuridica, non sono dei tecnici del diritto, come sono invece nel sistema giudiziario dello Stato moderno. Non solo, ma nel caso della democrazia ateniese il tribunale popolare, sia per il numero dei giudici componenti la giuria (un minimo di 201) sia per le modalità di nomina (sorteggio fra tutti i cittadini), vuole incarnare il principio che le controversie fra i cittadini devono essere risolte dalla comunità intera. Anche nella riflessione dei principali filosofi, Platone ed Aristotele, l'attenzione verso la funzione giudiziaria si concentra su due elementi: la provenienza dei giudici e le modalità di scelta. Aristotele (Polit. 1300a) traccia una linea di demarcazione fra tribunale democratico (nominato mediante sorteggio fra tutti i cittadini) e tribunale oligarchico (eletto all'interno di un ceto ristretto di cittadini: è il requisito che troviamo espresso dalle parole aristinden kai ploutinden in una famosa iscrizione della Locride Ipocnamidia intorno all'anno 500 a.C.: IG IX I' 717).

Dunque sia nelle città democratiche sia in quelle oligarchiche la funzione giudiziaria è attribuita a organi appositi, i dikasteria composti dai dikastai, distinti sia dalla magistratura (che conserva limitati poteri giudiziari nell'ambito 
della sua funzione di mantenimento dell'ordine pubblico) sia dall'assemblea dei cittadini (anche se ad Atene e forse anche in altre città, l'assemblea conserva una competenza giudiziaria straordinaria in casi di reati che mettano in pericolo la sicurezza della polis)'. Certo le nostre conoscenze dell'organizzazione giudiziaria nelle poleis diverse da Atene restano molto frammentarie e lacunose. Anche a Gortina, la città cretese di cui conosciamo abbastanza bene l'ordinamento giuridico privato grazie al c.d. Codice di G. e agli altri testi epigrafici fra VI e V secolo a.C., sappiamo che esistevano dei singoli dikastai, la cui competenza era distinta per materia - un tratto singolarmente moderno. Questi giudici erano tenuti a pronunziare le loro sentenze seguendo una duplice modalità di giudizio: lo sappiamo da una norma del Codice che impone ai giudici di pronunciare una sentenza conforme al mezzo di prova previsto dalla legge nel caso specifico (testimonianza o giuramento della parte): dikazen; in tutti gli altri casi, cioè quando la legge non richiede alle parti di presentare una prova vincolante per il giudice, il giudice deciderà liberamente, dopo aver prestato giuramento: omnunta krinen (dove non è chiaro se il giudice giuri di giudicare in base alla legge o in base alla propria coscienza) ${ }^{2}$.

3. In ogni caso l'idea che il giudice debba basare la sua sentenza sulle leggi, cioè debba applicare al caso concreto la previsione di legge, e, reciprocamente, che il legislatore debba formulare il testo di legge in funzione della sua applicazione da parte dei giudici, sembra radicata nella mentalità greca: di ciò possiamo trovare conferma nella riflessione filosofica.

Come è noto Platone pone al centro della sua riflessione sulla legge il problema della riduzione a una previsione generale e astratta di tutta la infinita molteplicità del reale (con le diverse soluzioni adottate nella Repubblica, nel Politico e nelle $\left.L e g g^{\prime}\right)$. E' un problema che ha le sue ricadute pratiche non solo dal punto di vista della regolamentazione del comportamento dei cittadini, ma anche e proprio in sede di risoluzione delle controversie. Quanto ad Aristotele, è nota la distinzione fra lacune involontarie e lacune volontarie riscontrabili nella legislazione (Rhet. Cap. 13). Le lacune volontarie sono date proprio dall'impossibilità per il legislatore di prevedere ogni possibile

\footnotetext{
' Per le recenti discussioni sulle caratteristiche statuali della polis v. M. Faraguna, Individuo, Stato e comunità. Studi recenti sulla polis, Dike 3, 2000, p.217-226.

${ }^{2}$ IC IV 72, col. XI 26-29.
} 
comportamento. Si apre dunque lo spazio all'interpretazione della legge, che in Grecia appare rimessa essenzialmente ai giudici, in assenza di una riflessione giurisprudenziale.

4. In questa dialettica tra legislatore, che formula le leggi, e giudice, che è tenuto ad applicarle, sembra esaurirsi l'intero universo giuridico greco. Tuttavia c'è spazio per un'altra dimensione della risoluzione dei conflitti che consiste nell'arbitrato. La figura del diaitetes non riceve una particolare attenzione a livello di riflessione etico-politica, e tuttavia ha un ruolo giuridicamente riconosciuto nell'ambito delle controversie di carattere privato fin da epoca antica (tanto è vero che, sia per la Grecia sia per Roma, si discute se la giurisdizione statale sia derivata dall'arbitrato). Così importante è il ruolo della giustizia arbitrale che il processo privato può essere in qualunque momento interrotto, prima che si arrivi al dibattimento, da un accordo delle parti per investire della questione un arbitro (anche questo è un principio che riecheggia nella Costituzione francese del 1791: cap. V artt. 5 e 6). E' in Aristotele, Rhet. 1374a-b, che troviamo una prima e fondamentale trattazione dell'equità (epieikeia): un testo molto denso ${ }^{3}$, da cui, secondo me, si ricava che, per Aristotele, epiekeia è sia un criterio di interpretazione della legge scritta sia un criterio di integrazione e superamento della legge stessa.

5. Fra i molti altri aspetti, che sono implicati dal rapporto legislazione/ giurisdizione, accenno qui soltanto al problema della messa in moto del procedimento giudiziario. Una invenzione che sembra proprio di dover attribuire ai Greci è costituita dall'accusa pubblica svolta da un privato cittadino. È infatti a Solone che si deve, secondo le fonti, la creazione della azione pubblica, detta graphe, intentabile da qualunque cittadino volontario (ho boulomenos), a tutela sia di interessi pubblici sia di interessi privati non adeguatamente tutelati dall'iniziativa privata. Questa istituzione si diffonde nel corso del tempo in tutto il mondo greco'.

"V. da ultimo J.-M. Bertrand, Rhétorique judiciaire et rétroactivité de la loi en Grèce antique in P. Sineux (ed.), Le Législateur et la loi dans l'Antiquité, Caen 2005, p.84. ss.

' Si veda l'articolo di L. Rubinstein, Volunteer Prosecutor in the Greek World, Dike 6, 2003, p.87-114. 
6. Se consideriamo ora il rapporto fra norma e applicazione giudiziaria di essa a Roma, dobbiamo tener conto prima di tutto che non esiste un momento storico che possa essere assunto come paradigma, il che accade sostanzialmente in Grecia con l'Atene del IV sec. (basta pensare al fondamentale libro di Hansen sulla democrazia ateniese del IV sec.'). Tuttavia ci sono forse alcune linee di tendenza che possono essere enucleate per caratterizzare questa problematica.

Prima di tutto va ricordato che il diritto romano non è un diritto basato in maniera precipua sulla legge, scritta o non scritta che sia. Se si fa eccezione per le XII Tab., che non sembrano aver mutato le strutture normative tradizionali, nei primi secoli della Repubblica il diritto privato romano continua ad avere il suo nucleo fondamentale nel diritto consuetudinario, i mores maiorum, da cui scaturisce lo ius civile, ma anche l'ossatura del diritto costituzionale. A questo nucleo fondamentale, la cui applicazione richiede quasi di necessità la mediazione dei giuristi, si sovrappone, come è noto, una pluralità di fonti normative, di cui la più importante è ovviamente l'Editto del Pretore. Lo strumento legislativo resta invece in secondo piano, almeno nel settore del diritto privato; mentre, per quanto riguarda il diritto pubblico, la legge appare soprattutto come uno strumento di lotta politica contingente.

7. Per quanto riguarda il rapporto fra legislazione e giurisdizione, occorre rilevare che fin da epoca antica la linea di demarcazione fra processo privato (civile) e processo pubblico (criminale) appare tracciata in modo piuttosto netto. Il processo privato più antico (c.d. processo per legis actiones) appare fortemente impregnato di elementi sacrali (in particolare nel caso della $l$. $a$. sacramento ${ }^{6}$ ) e comunque estraneo all'idea di un'applicazione della legge da parte di un giudice. C’è però una delle legis actiones, quella per iudicis arbitrive postulationem, che, al di là di tutte le controversie specialistiche sulla sua portata, mostra nel nome stesso la rilevanza di una giustizia arbitrale, in qualche modo diversa, se non alternativa, rispetto a quella ufficiale.

"M.H. Hansen, The Athenian Democracy in the Age of Demosthenes, Oxford 1991. Di questo libro sono disponibili varie traduzioni. La più recente, in lingua italiana, è stata pubblicata nel 2004. a Milano presso la casa editrice Led.

"Su cui v. da ultimo R. Martini, Considerazioni comparatistiche in tema di sacramentum, in Mélanges F. Sturm, 1999, I, p.385-394. 
Per quanto riguarda il processo penale, il ruolo preponderante del magistrato cum imperio (che implica un potere coercitivo dall'intensità sconosciuta ai magistrati a noi noti delle città greche) viene messo in discussione con tutta probabilità nell'ambito della dialettica politica fra patrizi e plebei. Attraverso l'introduzione della provocatio ad populum il processo criminale rimane dunque nell'ambito di una dialettica fortemente politicizzata: il comizio centuriato giudica in presa diretta, attuando quindi un modello di giustizia "politicizzata" che nelle città greche tende ad essere superato già in epoca antica (come abbiamo visto, il dikasterion acquista presto la propria fisionomia distinta, indipendentemente dalla sua effettiva composizione).

8. Gli ultimi due secoli della Repubblica vedono realizzarsi mutamenti decisivi per quanto riguarda il rapporto norma/giurisdizione.

Nel campo del processo privato si afferma la giurisdizione del pretore, il quale aggiorna il nucleo antico dello ius civile attraverso la concessione di rimedi giudiziari (azioni, eccezioni, interdica, missiones in possessionem etc.) a tutela di nuovi rapporti. E' di nuovo il carattere incisivo dell'imperium che spiega l'ampiezza dell'intervento del pretore. Come è noto, però, il nuovo processo privato, chiamato formulare, affida la decisione della lite a un giudice privato, scelto di comune accordo fra le parti e investito dal pretore del potere di giudicare. Da questo punto di vista, dunque, il iudex privatus è più vicino alla figura dell'arbitro di quanto non lo siano i giudici greci, eletti o sorteggiati che siano. Questo fa sì che il giudice romano possa decidere seguendo modalità molto più informali rispetto ai giudici greci, anche se in qualche misura risulta vincolato dal contenuto della formula che gli viene trasmessa dal pretore.

Nel campo del processo criminale assistiamo invece, a partire dalla metà del II sec. a C., alla nascita delle cosiddette quaestiones perpetuae. Si tratta di una forma di processo, in cui la componente politica ha un ruolo importante, soprattutto quando la giuria risulta composta esclusivamente da senatori. E anche quando i cavalieri entreranno nelle giurie, si tratterà comunque di un tribunale caratterizzato da un'impronta nettamente oligarchica (alla luce dei criteri di valutazione della teoria politica greca). In senso invece più "democratico" (sempre in una chiave di valutazione greca) va il fatto che l'accusa nelle quaestiones non è più sostenuta da un magistrato, come accadeva nell'antico processo comiziale, bensì da un privato cittadino: ci si 
avvicina quindi al modello dell'accusatore volontario, che, come abbiamo visto, caratterizzava le azioni pubbliche nel mondo greco.

Un altro elemento significativo, nell'ottica in cui ci siamo posti, è il moltiplicarsi di leggi che tendono a disciplinare il processo criminale: con Silla i reati repressi mediante la procedura delle quaestiones sono presi in considerazione da leggi specifiche, in cui vengono definite tanto la competenza dei singoli tribunali per i singoli reati quanto le pene da applicare. Dunque per la prima volta a Roma i giudici sono vincolati all'osservanza della legge. Il fondamento legislativo dell'organizzazione del processo, inclusa l'attività dei giudici, trova la sua consacrazione nelle due grandi leggi augustee (I. Iulia iudiciorum publicorum e iudiciorum privatorum), il cui contenuto è andato purtroppo perduto.

Ma questo discorso vale essenzialmente per il processo criminale. La materia privatistica, a cui si riferiscono le controversie civili, non viene regolata mediante leggi o altri strumenti normativi. Sono invece i giuristi che propongono al giudice le soluzioni del caso concreto, spesso contrastanti fra loro. In un certo senso si potrebbe dire quindi che il processo civile nella Roma classica è improntato a un modello platonico, in quanto la soluzione delle controversie è determinata da un diritto giurisprudenziale del caso concreto, non da regole generali stabilite per legge.

9. Il quadro cambia naturalmente man mano che si procede nell'età imperiale. Si afferma infatti il sistema giudiziario basato sulla cognitio extra ordinem, cioè al di fuori del sistema giudiziario consacrato per legge da Augusto. Il Senato acquista una funzione giurisdizionale nel campo di alcuni crimini pubblici (di grande interesse, in questo settore, il S.C. de Cneo Pisone ritrovato in Spagna ${ }^{7}$ ); ciò comporta che si abbia in questi casi una coincidenza fra organo legislativo (dato che i comizi vanno perdendo rapidamente la loro potestà legislativa) e organo giudiziario. A sua volta l'Imperatore entra prepotentemente nel quadro dell'ordinamento giuridico, tendendo a unificare nella sua cancelleria funzione normativa e funzione giudiziaria. Il processo privato non è più bipartito: il ruolo di magistrato e insieme di giudice è ricoperto da funzionari imperiali che godono di ampio potere discrezionale nel risolvere le controversie. Nuovi strumenti processuali, anche a tutela di

'A. Caballos, W. Eck, F. Fernández, El «senadoconsulto de Cne. Pisón padre”, Scvilla 1996. 
nuove esigenze (fedecommessi, azioni di figli contro il paterfamilias, azioni per alimenti etc.), sono introdotti presso i tribunali extra ordinem.

10. Ho richiamato fino a qui in maniera molto schematica la storia delle istituzioni giudiziarie in Grecia e a Roma con particolare riferimento al tema dei rapporti fra legislazione e giurisdizione. Sarebbe interessante approfondire molti aspetti particolari di queste vicende. Mi limiterò qui a segnalare, in chiusura di questo mio intervento, il tema del collegamento (o del coordinamento) fra istanze normative e giudiziarie orizzontalmente e/o verticalmente connesse, una tematica che potrebbe rivelarsi di fondamentale importanza per gli sviluppi dell'ordinamento giuridico europeo. Mi riferisco, ad esempio, da un lato all'età ellenistica, dove vediamo coesistere, all'interno delle grandi monarchie, sistemi giuridici unificati sostanzialmente dalla persona del re, mentre nell'ambito del tradizionale mondo delle polis vediamo affermarsi nuove soluzioni nel quadro dei trattati di isopoliteia e di synpoliteia; dall'altro, per quanto riguarda il mondo romano, ai rapporti fra gli organi normativi e giudiziari centrali e il sistema municipale, una tematica a cui la pubblicazione della lex Irnitana ha dato nuovo impulso.

"J. Gonzalea Fernandez, The "Lex Irnitana". A New Copy of the Flavian Municipal Law, JRS 76, 1986, p.147 ss. 


\title{
O DIREITO ROMANO E SEU CONTRIBUTO PARA A CONSTRUÇÃO DA EUROPA
}

\author{
Marleine Paula Marcondes e Ferreira de Toledo \\ (Universidade de São Paulo - USP \\ Universidade de Sorocaba - UNISO)
}

A formação jurídica ocidental é romana; por isso, o Direito Romano marca presença ainda hoje em todos os nossos códigos. O próprio modus dicendi forense aproxima-se do estilo ciceroniano, além de não dispensar os data venia, dies a quo, dies ad quem, pro rata, intuitu personae, etc. etc. $\mathrm{Na}$ Europa também é assim. Como diz Max Kaser', “(os) juristas (romanos) conduziram o direito privado a uma grande perfeição e proporcionaram-lhe, no pensamento jurídico de (sic) humanidade um prestígio intelectual que, muito pesa além do tempo histórico de vida do povo romano, se perpetua até ao presente. Ainda hoje as ordens jurídicas privadas dos países do continente europeu e dos territórios ultramarinos por eles influenciados se baseiam em grande parte nos princípios do Direito Romano".

A Europa já foi, em passado remoto, uma grande comunidade cultural e espiritual. A filosofia grega, a romanização (que levou em seu bojo o Direito Romano) e a cristianização formam o tripé deste que pode chamar-se o primeiro processo globalizador.

' Direito Privado Romano. Tradução de Samuel Rodrigues e Ferdinand Hämmerle; revisão de Maria Armanda de Saint-Maurice. Lisboa: Fundação Calouste Gulbekian, 1999, p.17. 
O pensamento racional europeu nasceu na Grécia, mais precisamente na Jônia, no século VI a.C." As interrogações fundamentais do homem sobre o universo, sobre o mundo, sobre a vida, sobre a morte e sobre si mesmo, e as primeiras respostas despontam nos fragmentos dos filósofos pré-socráticos:

"Panta rei"; não passarás duas vezes pelo mesmo rio; os elementos são quatro; o ser é o único e imóvel - e vieram desembocar naturalmente na maiêutica de Sócrates, na dialética de Platão, na lógica de Aristóteles.

Descartes sintetizou tudo isso no seu Cogito, dando força e crescimento ao racionalismo. Em última análise, tudo o que se construiu depois em matéria filosófica foi confirmar ou contrariar esse excêntrico francês. Mas o importante é que, em terras européias, facta erat ratio.

A antiga Roma, sobretudo a culta Roma do século I a.C., também andou bebendo em águas gregas:

Quanquam te, Marce fili, annum iam audientem Cratippum, idque Athenis, abundare oportet praeceptis institutisque philosophiae, propter summam et doctoris auctoritatem et urbis...

Ainda que convenha que tu, Marco (meu) filho, ouvindo Crátipo já há um ano, e isto em Atenas, tenhas em abundância preceitos e regras de filosofia, por causa da suprema autoridade não só do mestre, mas também da cidade..."

começa Cícero no De oficiis, prestando sem querer à posteridade um depoimento de que a força bélica de Roma, sua astúcia e praticidade não podiam alcançar a vitória sobre a cultura helênica.

A viagem cultural realizou-se da Grécia para Roma e de Roma para outras regiões da Europa. Com efeito, Roma não pôs em marcha apenas suas hostes, ao estabelecer um império, que, em três séculos, dominou a bacia do Mediterrâneo, adentrou África e Ásia, espalhou-se pela Europa, atingindo a Inglaterra: com o sermo vulgaris dos soldados seguiam as instituições romanas: o comércio, a escola, a administração, o Direito.

${ }^{2}$ Cf. VERNANT, Jean-Pierre. Mito e pensamento cntre os gregos. Trad. de Haiganuch Sarian. São Paulo: Difusão Européia do Livro - Editora da USP, 1973, p.293.

"CÍCERO. De oficiis. Trad. de Maximiano Augusto Gonçalves. Rio de Janeiro: Livraria H. Antunes Ltda. Editora, p.13. 
Ubi societas, ibi jus. Onde existe sociedade, onde há pessoas convivendo amigável ou não amigavelmente, há necessidade do Direito, de estabeleceremse regras objetivas de conduta que devem ser respeitadas por todos, ainda que à custa de sanções; do contrário, a convivência se torna impossível e não se pode estabelecer nenhum tipo de comunidade. Mas ánthropos politicón zóon e nenhum homem é uma ilha - o que torna o direito uma exigência conatural ao ser humano.

Roma deu-se conta disso. E logo. As primeiras leges já datam da Realeza (753 a 510 antes de Cristo). Vão-se desenvolvendo, crescendo, aperfeiçoando, especializando, formando coleções (como as memoráveis Doze Tábuas, de 450 a.C.) durante a República (510 a 27 antes de Cristo), o Alto Império ou Principado (27 antes de Cristo a 284 depois de Cristo) e o Baixo Império (284 a 565 depois de Cristo). Neste último período, sob o império de Justiniano, já em Constantinopla, chegam à mais perfeita e completa codificação (Corpus Juris Civilis) - mas ainda prosseguem durante um período pós-justinianeu, até a tomada de Constantinopla pelos turcos, em 14.53.'

Tudo o que foi possível compilar em matéria de Direito Romano fragmentos, decisões jurisprudenciais, editos, interpretações, leis, brocardos está nesse Corpus.

O Corpus data do século VI da nossa era e por ordem do Imperador foi colocado em vigor em todos os seus domínios. Na Europa romanizada também, por conseguinte. Constituem-no o Código Antigo, compilado em 529, hoje perdido; o Digesto, de 533; as Institutas, igualmente de 533; o Código Novo, de 534; as Novelas.

O Digesto (do latim digestus, digerido, organizado), também denominado Pandectas (do grego pan, tudo, e décomai, encerrar: encerra tudo) é a mais importante das compilações justianianas e reúne os escritos dos juris-consultos, os jura. Compreende cinqüenta livros, distribuídos em sete partes.

' Cf. JÚNIOR, J. Cretella. Dircito Romano modcmo. 6. ed. Rio de Janeiro: Forense, 1994. Cf. também ALveS, José Carlos Moreira. Direito Romano. 6. ed. Rio de Janeiro: Forense, v. I., 1987. 
As Institutas são um pequeno manual para o estudo do Direito, destinado aos alunos da escola de Direito de Constantinopla. Formam-nas quatro livros.

O Código Novo é uma atualização do perdido Código Antigo, formado por doze livros.

As Novelas, ou Autênticas, são um conjunto de novas constituições imperiais, decretadas por Justiniano, nos últimos anos de seu reinado, para atender aos novos casos que surgiam.

O jurisconsulto presidente da comissão organizadora do Corpus, durante quase toda a sua composição, foi Triboniano.

Justiniano era um homem singular. Não tinha cultura, não nasceu em Roma, não possuía nome latino. Natural de Taurésio, seu nome era eslavo (Upranda); passou a chamar-se Justiniano por ordem de seu tio, o imperador Justino, a quem sucedeu no governo.

Diz-se que Justiniano mal sabia as primeiras letras - mas era um homem de ferro: dedicou-se posteriormente às ciências, artes e direito. Em Constantinopla, mandou construir a basílica de Santa Sofia, hoje museu sacro.

Casou-se com a corajosa e ambiciosa cortesã Teodora, que sempre foi seu esteio. Por ocasião da revolta de Nike (532), julgando-se perdido, Justiniano quis abandonar o governo do Império, mas foi impedido pelas ousadas palavras da mulher: "Vai, César, se queres fugir. Os navios te esperam. Eu fico. A púrpura é bela mortalha para a imperatriz de Bizâncio".'

Se o Direito Romano fascinou Justiniano, um estrangeiro, fascinaria também os povos conquistados. Fascinaria a Europa.

242 Não sem razão, na recém-nascida România (Europa romanizada ou em processo de romanização) era necessário um Direito para governar os povos conquistados (ubi societas, ibi jus), suplantando os rudimentares e empíricos Direitos locais, consuetudinários.

${ }^{5}$ Cf. JÚNIOR, J. Cretella. Direito Romano modemo..., p.36 ss.

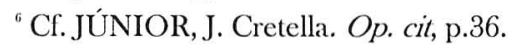


O Direito Romano indubitavelmente tem características que o colocam em posição de superioridade sobre os seus coevos.

É sobretudo um Direito Civil, que se apóia na natureza, mantendo íntima relação com a realidade. É, pois, em primeiro lugar, um Direito Natural, oriundo da razão e de uma espécie de providência divina (divina providentia, no dizer de Cícero): Est quaedam vera lex, naturae congruens, diffusa in omnes, constans, sempiterna 'Há uma lei verdadeira, segundo a natureza, espalhada entre todos os homens, constante e eterna' (De republica, 3, 22 33).'

Este jus naturale abrange um conjunto de regras inatas na natureza humana, que permitem ao homem agir com retidão; seus preceitos advêm da razão pura, sendo universais e imutáveis no tempo e no espaço - ou da razão prática, que adapta o universal às circunstâncias particulares".

O Direito Romano é também um jus gentium, direito dos povos, óvulo do Direito Internacional, que amplia o jus naturale para estendê-lo aos povos conquistados; é um Direito comum a todos os povos (gentes) do vasto mundo romano (orbis romanus)". Disciplinava as relações particulares entre cidadãos romanos e estrangeiros (peregrini); era tido como o Direito comum ao gênero humano, conseqüência forçosa das relações particulares entre os homens de todas as nacionalidades, fundado na razão natural. ${ }^{10}$

O Direito Romano é fundamentalmente jurisprudencial, tem poucas leis - o que combina com o espírito romano, pragmático e objetivo. Essa jurisprudência atravessou séculos e ainda orienta as lides atuais.

Finalmente, o Direito Romano foi construído por juristas reconhecidamente idôneos e competentes (Capito, Sabino, Cássio, Javoleno, Sálvio Juliano, Labeão, Próculo, Celso, Nerácio, Papiniano, Gaio, Paulo, Ulpiano...), cujos fragmentos e brocardos têm até hoje validade, primando pela concisão e objetividade: Qui tacet, non utique fatetur: sed tamen verum est, eum non negare 'O que cala, certamente não confessa; mas é certo que também não nega' (Paulo)."

'Cf. JÚNIOR, J. Cretella. Direito Romano modemo. 6. a ed. Rio de Janeiro: Forense, 1994, p. 27.

" Cf. SIDOU, J. M. Othon (org.). Dicionário jurídico da Academia Brasileira de Letras Jurídicas. 4. ed. São Paulo: Editora Forense Universitária, 1997, verbete Direito Natural.

" Cf. JÚNIOR, J. Cretella. Op. cit. , p. 11.

${ }^{10}$ Cr. ACQUaviva, Marcus Cláudio. Dicionário jurídico brasileiro Acquaviva. São Paulo: Editora Jurídica Brasileira Ltda., 1998, verbete Jus Gentium.

" FRANÇA, R. Limongi. Brocardos jurídicos. As regras de Justiniano. 2. a ed. São Paulo: Editora Revista dos Tribunais, 1969, brocardo 142, p.109. 
Nem tudo, porém, nesse Direito tem correspondência na virtude. Alguma aproximação desses dois campos se faria a partir do séc. I d. C. com a chegada do Cristianismo à urbs. $\mathrm{O}$ mandado de Jesus Cristo ressuscitado aos apóstolos era de irem a todos os povos, batizá-los, fazê-los discípulos, ensinando-lhes tudo o que Ele próprio lhes ensinara (Cf. Mt 28). Foram também - e logo - a Roma. No primeiro século há uma Carta de Paulo aos Romanos, o que comprova já existir uma comunidade cristã em Roma.

Segundo Duchesne ${ }^{12}$, o Império Romano foi "a pátria do Cristianismo", porque a Pax Romana favorecia os intercâmbios necessários.

Diante dos apóstolos se apresenta um mundo em que a virtude não está morta, mas agoniza: triunfam oficialmente o dinheiro, o sexo, o gozo, a força, o desprezo ao pobre; um mundo cuja maioria é uma massa de escravos, base econômica do império, e de peregrini, gente sem lar nem pátria.

Ainda existem matronas romanas à antiga, mas uma sexualidade desenfreada expressa o desprezo pela mulher. Nesse ambiente, o Cristianismo propunha uma vida, uma doutrina e uns costumes que não são inéditos, mas que reaparecem com a vida e a pregação cristãs:

"Os cristãos não se diferenciam dos outros homens nem pelo país, nem pela língua, nem pelas instituições. De fato, não moram em cidades próprias, nem empregam linguagem estranha nem levam uma vida diferente. Moram em cidades gregas ou bárbaras, conforme o acaso os colocou; seguem os costumes do povo local em matéria de roupas e de alimentos e, quanto ao mais, manifestam seu admirável modo de viver e propõem ao consenso de todos o incrível estado de sua vida. Habitam em suas pátrias, mas como inquilinos; têm tudo em comum com os outros como cidadãos e tudo suportam como peregrinos. Todo país estrangeiro lhes é pátria e toda pátria, terra estrangeira. Casam-se como todo mundo e procriam, mas não rejeitam os fetos. Têm em comum a mesa, não o leito"'t3.

A perseguição romana e o martírio cristão, durante os três primeiros séculos da igreja, são fatos sobejamente conhecidos. Nero deu um instru-

${ }^{12}$ Citado por PIERRARD, Pierre. História da Igreja. Trad. de Álvaro Cunha. São Paulo: Paulinas, 1982, p.25.

${ }^{13}$ Epístola a Diogneto. Em: Liturgia das Horas. São Paulo: Paulinas, 1978, p.419. 
mento jurídico à ação contra os cristãos, o Institutum Neronianum, cuja proibição mais importante era non licet esse christiannos". Havia-os, entretanto, e obviamente influenciaram o Direito Romano, sobretudo quando, com o imperador Constantino (313), o Cristianismo se torna a religião oficial do Império. Marcou presença principalmente no Direito de Família (matrimônio, segundas núpcias, divórcio) e com menos intensidade nos direitos patrimoniais $^{15}$. Amenizou também a condição dos escravos, embora não extinguisse a escravidão. ${ }^{16}$

À semelhança das hostes romanas, começou a adentrar a Europa o modesto exército cristão, sobretudo a partir da conversão do imperador Constantino, cujo edito de Milão (313) concedia liberdade de culto e ressarcia os prejuízos sofridos pelos cristãos.

Convertido o imperador, todo o império é obrigado a converter-se.

Os símbolos cristãos começam a substituir os signos pagãos; as basílicas multiplicam-se em Roma e em todo o império; o vocabulário cristão penetra na legislação; os julgamentos dos tribunais episcopais passam a ter validade oficial.

Teodósio, que sucedeu a Constantino, destruiu o politeísmo romano, confiscou os bens dos templos pagãos, entregando-os às igrejas. Apesar de muitas precariedades, começam a florescer comunidades cristãs em todo o Império.

A Igreja enviou seus santos para evangelizarem a Europa, romanizada ou em processo de romanização: São Tiago foi para a Galícia; Justino morreu mártir em Roma. Os godos foram evangelizados por um de seus prisioneiros, chamado Úlfilas; São Patrício foi o apóstolo da Irlanda; S. Ambrósio é bispo de Milão; S. Martinho vai para a Gália Central. A vida monástica começa a organizar-se. Citam-se ainda Hilário de Arles, Pedro Crisólogo, Isidoro de Sevilha, Martinho de Braga, fundador da igreja portuguesa - e muitos outros. Todos esses homens santos fizeram da Europa uma filha da Igreja.

\footnotetext{
" Citado por PIERRARD, Pierre. História da Igreja..., p. 27.

${ }^{15}$ Cf. ALVES, José Carlos Moreira. Direito Romano. 6. a ed. rev. e acres. Rio: Forense, 1987, v. I, p.63 ss.

${ }^{16}$ Cf. JÚNIOR, J. Cretella. Op. cit., p.91.
} 
Antes mesmo de Constantino, o Cristianismo ainda perseguido já começava a espalhar-se pelo império, pois havia soldados cristãos nas legiões romanas, como demonstra o incidente ocorrido com uma legio fulminata:

"No século II, quando Marco Aurélio era imperador de Roma, as legiões romanas estavam lutando contra os Quados, nas cercanias de Grã, perto do rio Danúbio, na Hungria atual. Os Romanos estavam em uma situação difícil, porque os Quados lhes haviam cortado o abastecimento de água e eles estavam a ponto de morrer de sede, no calor escaldante. Providencialmente caiu uma chuva torrencial, e o mais espantoso é que nessa chuva a água caía sobre os Romanos, aliviando-os da sede, e os raios caíam sobre os Quados, desbaratando-os, causando a maior confusão. Estes ficaram tão perplexos, que se imiscuíram nas fileiras dos inimigos e foram derrotados.

$\mathrm{Na}$ legião romana havia pagãos e cristãos. Os pagãos atribuíram este milagre a Júpiter Pluvius, que era honrado pelo Imperador, e os cristãos atribuíram-no a Deus, querendo com isto obter o fim das perseguições". ${ }^{17}$

Diante do exposto, é possível ratificar o que com toda a razão afirmou o Prof. Antônio Santos Justo, no I Congresso da APEC, realizado aqui mesmo, nesta Universidade de Coimbra: "Quanto à Europa, ninguém duvida de que a sua identidade espiritual é marcada não apenas pela religião hebraica e pela filosofia grega, mas também pelo Direito Romano"18

O ilustre professor, falando especificamente do Direito Romano, restringe-se a Portugal, como era o escopo de sua comunicação - e observa que curiosamente esse Direito, que entrou no Brasil por meio das Ordenações Filipinas, está hoje mais presente em terras brasileiras do que em portuguesas.

Não deixa de salientar, contudo, que o Direito Romano tem uma vocação universalista; "por isso, juntamente com a Política superiormente dirigida

${ }^{17}$ Fato relatado por Emest Renan, em Marc Aurèle, citado por SILVA, Célia Mariana F. F. da, em conferência proferida na Câmara Municipal de São José do Rio Pardo - SP, na sessão solene de abertura da Semana Euclidiana de 1996, em 9 de agosto.

${ }^{1 *}$ JUSTO, Antônio Santos. Direito Romano em Portugal. In: Raízes greco-latinas da cultura portuguesa. Actas do I Congresso da APEC. Coimbra, Portugal, 1999, p.279. 
para a felicidade dos súbditos, fez da pequena urbe um orbe e prestou, mais tarde, um notável contributo na construção da Europa"."

Entretanto, esta Europa globalizada no passado, através dos séculos, pelas vicissitudes históricas, foi-se esfacelando, sofrendo muitas cisões e confrontos armados que culminaram nas duas grandes guerras do século XX.

Atualmente alguns Chefes de Estado europeus - por razões políticas e econômicas - voltam-se para a consolidação de uma comunidade européia, a União Européia. Vários tratados mais ou menos recentes procuraram solidificar esta união, na esfera econômica, como, por exemplo, a criação do euro. Verificou-se, porém, que só a integração econômica não é eficaz, que moeda não une nações. Daí caminhar-se para a idéia de cidadania, uma cidadania pan-européia, numa união de cidadáos europeus.

Pelo tratado de Mastricht foi instituída a cidadania da União Européia, uma cidadania supranacional, à qual foram atribuídos direitos e deveres. Uma espécie de identidade coletiva. ${ }^{20}$

O que significa cidadania?

O étimo é o latim civitas, cidade. No Direito Romano, civitas era o conjunto dos cidadãos que constituíam uma cidade; daí o vocábulo civil. Não era o mesmo que a urbs (conjunto de edificações) habitada pelos cidadãos. O significado de civitas é o de pólis, isto é, político. A civitas era, pois, a comunidade organizada politicamente; o status civitatis era o estado de cidadão. O cidadão tinha direitos e deveres para com a civitas. ${ }^{21}$

Em que sentido o Direito Romano pode contribuir hoje para a formação da cidadania européia e conseqüentemente para a construção de uma Europa una e coesa?

O Direito Romano, em sua orientação geral, aproxima-se da ética. Ulpiano afirma que os preceitos do Direito são: viver honestamente, não prejudicar a outrem, dar a cada um o que é seu Juris praecepta sunt haec: honeste vivere, alterum non laedere, suum cuique tribuere - Digesto, I, 1, 1; Institutas, $I, 1,3)^{22}$ - três preceitos muito aparentados com a moral.

${ }^{19}$ JUSTO, Antônio Santos. Op. cit, p.289.

${ }^{2}$ Cf. STELGES, Isabela Kathrin. A cidadania da União Européia. São Paulo: Del Rey, 2002, p.3 ss.

" Cf. ACQUAVIVA, Marcus Cláudio. Dicionário jurídico brasileiro Acquaviva. São Paulo: Editora Jurídica Brasileira Ltda., 1998, verbete Cidadania.

${ }^{22}$ Em JÚNIOR, J. Cretella. Direito romano modemo. 6. a ed. Rio de Janeiro: Forense, 1994, p.24. 
Além disso, já foi salientado o aspecto universalizante do Direito Romano em seu conjunto.

Muito bem. O projeto de constituição da União Européia, embora afirme que se inspira "nas heranças culturais, religiosas e humanistas"23 da Europa, é agnóstico. O penhor de cidadania que ele propõe é político-econômico: pertencer a um país democrático e usar o euro. Contudo, como tem premissas que toda constituição exige, premissas que são afirmações genéricas de boa vontade para com os povos, defende valores, faz bons propósitos. Neste aspecto, ouvem-se ecos do Direito Romano, que, conforme afirma A. Santos Justo, fez da libertas uma res inaestimabilis e é "um direito superiormente construído por jurisconsultos que se afirmaram verdadeiros sacerdotes da justiça e sempre entenderam que o ius está ao serviço da vida (hominum causa omne ius constitutum todo Direito é constituído em favor dos homens) e não esta ao serviço daquele'."

O preâmbulo do Projeto Constitucional pan-europeu, que faz vários considerandos de alto valor ético: a Europa é um continente portador de civilização; seus habitantes desenvolveram os valores do humanismo, quais sejam, igualdade de todos os seres, liberdade, respeito pela razão. Esses valores enraizaram na vida da sociedade o papel central da pessoa humana e dos seus direitos invioláveis e inalienáveis, bem como o respeito pelo Direito; a Europa, agora reunida, tenciona progredir (...) a bem de todos os seus habitantes, incluindo os mais frágeis e os mais desprotegidos, está decidida a ultrapassar as antigas discórdias (...) e forjar o seu destino comum; unida na diversidade, respeitando as identidades históricas das nações, está certa de ser um espaço privilegiado de esperança humana..."

Essa nota otimista, promissora e universalizante, presente nos princípios gerais do Direito Romano, aparece também em alguns brocardos deste Direito:

Ulpiano: Privatorum conventio juri publico non derrogat 'A convenção entre particulares não derroga o direito de ordem pública'. ${ }^{26}$

$248{ }^{2 x}$ PROJETO DE TRATADO QUE ESTABELECE UMA CONSTITUIÇÃO PARA A EUROPA. In: VIEIRA, José Ribas (org.). A constituição curopéia (o projeto de uma nova tcoria constitucional). Rio - São Paulo - Recife: Renovar, 2004, p.191.

${ }^{21}$ JUSTO, Antônio Santos. Direito Romano em Portugal. In Raízes greco-latinas da cultura portuguesa. Actas do I Congresso da APEC. Coimbra, Portugal, 1999, p.282.

${ }^{2}$ Cf. VIEIRA, José Ribas (org.). A constituição européia (O Projeto de uma Nova Teoria Constitucional), 2004, p.191 ss.

${ }^{*}$ FRANÇA, R. Limongi. Brocardos jurídicos. As regras de Justiniano. 2. ed. São Paulo: Editora Revista dos Tribunais, 1969, brocardo 4.5, \$1, p.68. 
Gaio: Semper in dubiis benigniora praeferenda sunt 'Nas questões dúbias se há de preferir o que for mais benigno'. ${ }^{27}$

Paulo: In omnibus quidem, maxime tamen in jure, aequitas spectanda est 'Em todos os casos, e especialmente nos de direito, a eqüidade deve ser atendida?.

Paulo: Libertas inaestimabilis res est 'A liberdade é uma coisa inestimável'."

Ulpiano: Nihil consensui tam contrarium est, ac bonae fidei judicia sustinet, quam vis, atque metus: quem comprobare, contra bonos mores est 'Nada é tão contrário ao consenso que sustém as ações de boa-fé, como a violência e o medo; admitir o inverso é contrário aos bons costumes. ${ }^{90}$

O texto propriamente dito do projeto tem uma primeira parte assentada sobre o Direito Público Internacional, na qual praticamente não há resquícios do Direito Romano, que era essencialmente privado e civil.

A instituições, contudo (Parlamento Europeu, Conselho Europeu, Conselho de Ministros) lembram de longe as romanas, sobretudo o Senado.

Ainda assim, alguns artigos dessa primeira parte podem ser confrontados com o Direito Romano - e, curiosamente, batem de frente com ele.

Nas questões da cidadania, por exemplo, o projeto não faz discriminações:

"Possui a cidadania da união todo o nacional de um Estado-membro. A cidadania da união acresce à cidadania nacional, não a substituindo" (Artigo I - 8oㅜㄴ Título II, ParteI).

Quer dizer: não há discriminações pessoais. Em Roma não era assim: o status civitatis valia só para os cidadãos romanos (Quirites), ficando fora os peregrini, que não tinham direito ao jus civile, mas ao jus gentium."

Conseqüentemente, o princípio europeu de igualdade democrática também contraria o Direito Romano, que discriminava entre servos e livres, estrangeiros e cidadãos romanos:

"Em todas as suas atividades, a União respeita o princípio da igualdade dos seus cidadãos, que beneficiam (sic) de igual atenção por parte das institui-

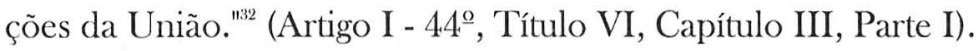

${ }^{27}$ FRANÇA, R. Limongi .Op. cit., brocardo 56, p.72.

${ }^{2 *}$ FRANÇA, R. Limongi. Op.cit., brocardo 90, p.88.

${ }^{2}$ FRANÇA, R. Limongi. Op.cit., brocardo 106, p.94.

"* FRANÇA, R. Limongi. Op.cit., brocardo 116, p.98.

${ }^{31}$ Cf. MARKY, Thomas. Curso elementar de Direito Romano. 8. ${ }^{\text {a }}$ ed. São Paulo: Saraiva, 1995, p.33.

${ }^{-32}$ VIEIRA, José Ribas (org.). A constituição curopéia (O Projeto de uma Nova Teoria Constitucional). Rio - São Paulo - Recife: Renovar, 2004, p.226 ss. 
A parte II - Carta dos Direitos Fundamentais da União, oferece maiores possibilidades de confronto com o Direito Romano, embora continue a contrariá-lo na maioria dos casos. É que Roma nunca foi uma sociedade igualitária - e a Constituição luta por instaurar a igualdade dos cidadãos dos países membros.

Façam-se algumas comparações:

"A dignidade do ser humano é inviolável. Deve ser respeitada e protegida" (Art. II - 1ํㅜㄴ Título I, Parte II);

"Todas as pessoas têm direito à vida." (Art. II - 2º, Título I, Parte II );

"Ninguém pode ser sujeito à escravidão nem à servidão" (Art. II - 5º, Título I, Parte II);

"Todas as pessoas têm direito à liberdade e à segurança" (Art. II - 6으, Título II, Parte II);

"Todas as pessoas são iguais perante a lei" (Art. II - 20º, Título III, Parte II).

Em Roma, absolutamente, não havia essa igualdade e liberdade: em certa época, Servus res est; o escravo é objeto de propriedade, pode ser vendido, destruído, condenado a trabalhos forçados e até lançado às feras do circo lad bestias)" ${ }^{k 3}$. A condição servil só melhorou um pouco com a influência do Cristianismo.

Ainda na Parte II, algumas proposições, aparentemente bem intencionadas, defensoras da não discriminação e do progresso, podem dar azo a ambigüidades, por serem muito genéricas.

Vejam-se as mais relevantes, em confronto com o Direito Romano - que quase não padecia de ambigüidades, porque estava assentado numa filosofia pragmatista e primava pela concretude.

Partamos de Roma:

No direito de Justiniano, nuptiae sive matrimonium est viri et mulieris conjunctio, individuam consuetudinem vitae continens 'Casamento ou matrimônio é a união de homem e mulher com indivisível costume de vida.".

Nem todos tinham direito ao casamento, havendo outras uniões menos nobres entre o homem e a mulher (concubinato, contubérnio, etc). E o casamento podia ser dissolvido pelo divórcio, que atingiu taxas tão altas no início do Alto Império, que chegou a preocupar o governo: dizia-se que

${ }^{3}$ Cl. JÚNIOR, J. Cretella. Op. cit, p.54.

" Cf. JÚNIOR, J. Cretella. Dircito romano moderno..., p.72. 
algumas mulheres contavam as datas pelos nomes dos maridos - havendo, conseqüentemente, uma crise de natalidade, uma degradação dos costumes e da família. ${ }^{35}$

A Constituição Européia prevê, em seu art. II - 9º, Título II, Parte II: "o direito de contrair casamento e o direito de constituir família são garantidos pelas legislações nacionais que regem o respectivo exercício." Associando esse artigo com o II - 21ํㅜ , Título III, Parte II, que proíbe discriminações, inclusive de "orientação sexual", como fica essa legislação sobre o casamento? Prevê ou não prevê a diferença sexual?

Voltemos à Roma.

A legislação protegia as crianças, até certo ponto, porque falava de recém-nascidos, mas não de fetos - e em certa época os filhos estavam totalmente sob o poder do pater familias, que podia rejeitar os recém-nascidos e abandoná-los, exceto matá-los (pela lei das XII Tábuas) ${ }^{36}$.

A Constituição Européia (art. II - 24ํㅡ, Título III, Parte II) dá muito maior proteção às crianças - mas também não fala do feto. Proíbe a clonagem humana (art.II - $3^{\circ} \mathrm{d}$, Título II, Parte II), todavia não impõe empecilhos à pesquisa:

Art. II - 13º, Título II, Parte II: "As artes e a investigação científica são livres. É respeitada a liberdade acadêmica".

Que objetos são passíveis de investigação científica, uma vez que o feto não é contemplado nesta carta de direitos?

A União Européia espera muito de sua Constituição. Colocou-lhe premissas de igualdade e solidariedade e fez uma carta de direitos bem mais humanitários que as preocupações político-econômicas em que se assenta a maioria de seus artigos. Mas esses pressupostos humanitários estão fundados em simples virtudes humanas e alguns são ambivalentes. Veremos o que dirá a História. Esperemos que prevaleça o brocardo do Direito Romano que previne contra o dolo:

Papiniano: Nemo potest mutare consilium suum in alterius injuriam 'Ninguém pode mudar o seu próprio desígnio em prejuízo de outrem'. ${ }^{37}$

${ }^{35}$ Cl. JÚNIOR, J. Cretella. Ibidem., p.79.

${ }^{36}$ Cf. JÚNIOR, J. Cretella. Op. cit., p.68.

${ }^{3}$ FRANÇA, R. Limongi. Brocardos jurídicos. As regras de Justiniano. 2. ed. São Paulo: Editora Revista dos Tribunais, 1969, brocardo 75, p.82. 
E não prevaleça aquele que separa o direito da moral:

Paulo: Non omne, quod licet, honestum est 'Nem tudo que é lícito é também honesto'."

Em suma, a primeira globalização da Europa se fez, na Antigüidade e Idade Média, sobre três pilares: a Filosofia Grega, o Direito Romano e o Cristianismo.

Vicissitudes históricas abalaram essa unidade, que, hoje, alguns Chefes de Estado europeus querem recuperar, com a União Européia.

Para tanto, propuseram o projeto constitucional que também se assenta num tripé: Economia, Política e Direito, aparentado com o Direito Romano em alguns aspectos; bem diferente, em outros.

O projeto demonstra boa vontade, mas peca pela horizontalidade. Sendo agnóstico, a falta de embasamento filosófico ou teológico reponta em algumas decisões, que poderão produzir controvérsias. Como pacta sunt servanda, esperemos para ver o que o futuro dirá.

\section{Bibliografia}

Acquaviva, Marcus Cláudio. Dicionário jurídico brasilciro Acquaviva. Sào Paulo: Editora Jurídica Brasileira Ltda., 1998.

Alves, José Carlos Moreira. Direito Romano. 6. a ed. Rio de Janciro, Forense, v. I., 1987.

Cíclero. De oficïs. Trad. de Maximiano Augusto Gonçalves. Rio de Janeiro: Livraria H. Antunes Ltda. Editora, s/d.

FranÇA, R. Limongi. Brocardos jurídicos. As regras de Justiniano. 2. ${ }^{\text {a }}$ ed. São Paulo: Editora Revista dos Tribunais, 1969.

Júni(OR, J. Cretella. Direito romano modemo. 6. a ed. Rio de Janeiro: Forense, 1994.

Justo, Antônio Santos. "Direito Romano em Portugal”. In: Raizes greco-latinas da cultura portuguesa. Actas do I Congresso da APEC. Coimbra, Portugal, 1999.

Liturgia das Horas. São Paulo: Paulinas, 1978.

${ }^{38}$ FRANÇA, R. Limongi. Op.cit., brocardo 144, p. 110. 
Kaslir, Max. Direito Privado Romano. Traducào de Samuel Rodrigues e Ferdinand Hämmerle; revisão de Maria Armanda de Saint-Maurice. Lisboa : Fundação Calouste Gulbenkian, 1999.

Pil:rrard, Pierre. História da Igreja. Trad. de Álvaro Cunha, São Paulo: Paulinas, 1982.

Sinout, J. M. Othon (org.). Dicionário jurídico da Academia Brasileira de Letras Jurídicas. 4. ed. São Paulo: Editora Forense Universitária, 1997.

Silva, Célia Mariana F. F. da em conferência proferida na Câmara Municipal de São José do Rio Pardo - SP, na sessão solene de abertura da Semana Euclidiana de 1996, em 9 de agosto.

Stric,gls, Isabela Kathrin. A cidadania da União Européia. Belo Horizonte, MG: Del Rey, 2002.

Vlirnant, Jean-Pierre. Mito e pensamento entre os gregos. Trad. de Haiganuch Sarian. São Paulo: Difusão Européia do Livro - Editora da USP, 1973.

Vilira, José Ribas (org.). A constituição européia (o projeto de uma nova teoria constitucional). Rio - São Paulo - Recife: Renovar, 2004. 
(Página deixada propositadamente em branco) 


\title{
IMAGENS DO AMOR EM SANTO AGOSTINHO *
}

\author{
Arnaldo do Espírito Santo \\ Universidade de Lisboa
}

A noção de amor em Santo Agostinho envolve matizes complexos e diversificados, pois que nos são dadas ao longo da sua obra definições que relevam do plano ontológico, outras que se inclinam para o domínio dos afectos e das emoções, outras que se situam no campo da ética religiosa, outras ainda que entram no âmbito da gnoseologia.

Numa primeira abordagem, o amor é tomado como uma entidade de carácter geral que se define no discurso linguístico pelos substantivos, adjectivos ou expressões que o determinam. Há um amor rectus e um amor pravus, um amor Dei e um amor sui; um amor carnis e um amor spiritualis, um amor rerum amandarum, que coincide com o conceito de charitas, um amor do que é eterno, e um amor que não passa de uma cupiditas rerum transeuntium; há um amor excellentiae que se confunde com a superbia, um amor laudis que é o mesmo que vanglória; um amor pecuniae que, por outros termos, é simplesmente a avareza; há um amor saeculi e um amor Dei, nas suas duas vertentes de amor hominum erga Deum e de amor Dei erga homines, há o amor proximi; há o amor esuriens do início da viagem mística para o sumo bem, e o amor fruens, o amor que repousa no objecto amado; há o amor indissociável do temor; não há amor sem dor; não há amor sem Fé e sem Esperança; todo o amor é uma força extraordinária bidireccional que aut ascendit aut descendit, e que torna fáceis as coisas difíceis; há o amor temperantiae, o amor forti-

\footnotetext{
* Com a devida autorização, reproduz, com ligeiras alterações, o artigo publicado em Humanitas 54 (2002) 101-113.
} 
tudinis, o amor iustitiae, o amor prudentiae; o amor é a perfeição do homem e a totalidade da sua vida; o amor é Cupido voando e sagitando, porque, irracional e instável, fere o coração dos infelizes; mas também é figurado como uma seta do mesmo Cupido, a qual, simbolizando a palavra de Deus, atinge a alma para a despertar para si; o objecto do amor é o bem, porque ninguém ama o mal enquanto mal; o amor é invisível; o amor é o próprio Deus, no seio da Trindade; há dois amores que definem duas cidades; não há amor sem conhecimento verdadeiro, pois ninguém ama o que não conhece; amar é conhecer e possuir; o amor é uma corrida como a do atleta no estádio, cujo prémio é o próprio Deus; o amor é forte como a morte; o destino final de todo o ser é o amor, princípio e fim de todas as coisas, porque ele é a vita vitarum. Enfim, o amor é uma espécie de densidade do ser: pondus meum amor meus.

Todos estes matizes são de Agostinho. E outros mais, muitos mais, ficaram de fora desta lista. Não há pormenor nem aspecto da consciência humana que escape a essa torrente avassaladora que é o amor.

Existem estudos profundíssimos, já clássicos, sobre o amor em Agostinho, quer do ponto de vista teológico e filosófico, quer na perspectiva da psicologia, com análises penetrantes e sábias no domínio da fenomenologia da consciência. Não é no limite destas páginas que vou referir sequer algumas das conclusões desses estudos. Além do mais, sobre este tema poderiam escreverse alguns volumes e bem grossos. Dissertar sobre elas em espaço tão reduzido não permitiria ir além de uma amável superficialidade, bem apoiada em autoridades, correndo o risco de repetir banalidades envoltas em frases bombásticas.

O meu propósito é, pois, abordar o tema do amor em Agostinho de tal modo que até as palavras sejam de Agostinho. Há trechos maravilhosos em que o lirismo do estilo e a vivacidade da emoção correm o risco de se desvanecerem quando tentamos dissecá-los numa análise esmiuçada de ideias e conceitos. Tanto quanto possível, deixarei falar os textos recorrendo profusamente à citação. Procurarei, além disso, dar relevo a aspectos menos glosados pelos especialistas de Agostinho.

A enumeração, com que iniciei este ensaio, sobre os vários matizes implícitos na noção de amor em Agostinho, mostra claramente que o amor é concebido como uma força que estende o seu império a todo o sistema de valores em que assenta a vida do ser humano, na sua relação, transcendental e 
horizontal, consigo mesmo e com o outro, com o indivíduo e com a sociedade. Não será exagerado dizer que Agostinho, ao empregar 6864 vezes as palavras amor, charitas, dilectio, contra 227 ocorrências de amicitia, numa proporção de 100 para 3, tinha plena consciência de que estava a mexer nos fundamentos da cultura e da sociedade antiga, já em vias de cristianização acelerada. Uma comparação feita com o uso do mesmo vocabulário em Cícero e Séneca só vem confirmar esta opinião. De facto, nem em Cícero nem em Séneca aparece a palavra dilectio, e caritas apenas umas 40 vezes em Cícero e 9 em Séneca. Mas o que mais interessa é que em Cícero é significativamente menor ó número de ocorrências de amor do que o de amicitia (356 contra 493, numa proporção de 72 para 100).

Esta estatística poderá parecer despropositada ao falar de amor, mas a verdade é que as palavras, mudadas, são aqui o reflexo das coisas e de outras mudanças. Numa sociedade fundada no relacionamento horizontal entre os indivíduos, regido por códigos morais exclusivamente humanos, sem um apelo à divindade, ética e ontologicamente fundamentado, a relação entre os indivíduos assenta na amizade'. E é precisamente esta palavra que quase desaparece para dar lugar à predominância absoluta de amor. O que Agostinho faz realmente é situar-se no quadro dos valores que regem os impulsos afectivos do ser humano, como ser individual e social, para lhe conferir outro tipo de fundamentações que a não muito longo prazo vão alterar completamente a mentalidade dos indivíduos: a principal dessas fundamentações consistiu em acentuar o sentido da verticalidade no relacionamento horizontal.

Desta forma, a sociedade antiga, fortemente alicerçada no valor da amizade, cedeu o lugar a uma forma de ver o mundo e a vida sob outro prisma, privilegiando outros nexos dos homens entre si, do homem consigo e do homem com a divindade.

Não admira, pois, que Agostinho implique na concepção de amor uma crítica tenaz e implacável a um dos mais nobres valores do mundo antigo, qual era o amor laudis ou amor gloriae, cultivado por heróis, incentivado por poetas e pedagogos, como um dos motores mais eficazes dos grandes feitos que engrandeciam a pátria que tais heróis gerava. Todos reconhecemos esse espírito em Homero, Píndaro, Virgílio, Horácio, Tito Lívio, Salústio, etc. Agostinho, porém, tem outra concepção sobre as motivações do agir humano. Mesmo na justa defesa da pátria, não deve ser a ambição de adquirir glória

Há também a pietas para com os deuses, para com"os pais e a família, e para com a pátria. Mas essa é outra questão e de outro domínio. 
humana o móbil da acção, mas antes um objectivo superior como a necessidade de garantir a liberdade e a salvação comum. Saliento três aspectos na argumentação usada por Santo Agostinho.

O primeiro é que a crítica ao amor humanae laudis é acentuada com expressões crescentemente negativas: cupiditas gloriae, cupiditas laudis humanae, aviditas laudis humanae. Numa expressão mais completa, o amor laudis et affectatio dominandi, que os animais não possuem, não dignifica o ser humano em relação aos irracionais, pois que se trata de um desejo (appetitus) irracional (rationi non subditus) que só pode levar à infelicidade. E Agostinho conclui assim o seu pensamento: «Non enim ordo rectus, aut ordo appellandus est omnino, ubi deterioribus meliora subjiciuntur»". Este princípio, se aplicado às sociedades humanas, constitui uma inversão dos valores da tradição ética do mundo clássico.

O segundo aspecto que convém salientar é que a argumentação de Agostinho se apoia em factos narrados por Salústio e celebrados por Virgílio, como que na intenção de atacar o problema na fonte, sabendo muito bem que ambos os textos não eram apenas um repositório dos valores consagrados, mas o meio mais eficaz de os transmitir de geração em geração. A primeira crítica de Agostinho incide sobre a história de Júnio Bruto, um dos dois primeiros cônsules de Roma, que esmagou uma tentativa de fazer voltar Tarquínio, o Soberbo, com a morte dos implicados no golpe, entre os quais se encontravam os filhos e a mulher de Bruto. Este episódio da história de Roma é apresentado e criticado por três vezes. E, embora Agostinho retome em pormenor a narrativa de Salústio, resume ou cita numa dessas vezes os versos 820-823 do livro VI da Eneida:

«Natosque pater nova bella moventes

Ad poenam pulchra pro libertate vocabit, Infelix, utcumque ferent ea facta minores ${ }^{3} . »$

Aí interrompe a citação para comentar que quem mata os filhos não pode ser feliz, e que o apelo ao amor da pátria não passa de uma vã consola-

"De Libero arbitrio, PL 32, 1231: "Nào se deve designar por ordem recta, e nem mesmo por ordem, quando as coisas melhores se subordinam às piores".

" ¿ $\mathrm{E} \mathrm{em} \mathrm{defesa} \mathrm{da} \mathrm{bela} \mathrm{liberdade} \mathrm{condenará} \mathrm{à} \mathrm{morte} \mathrm{/} \mathrm{os} \mathrm{seus} \mathrm{filhos} \mathrm{por} \mathrm{fomentarem}$ novas guerras: / infeliz, seja como for que os vindouros contem esses actos.» 
ção para essa infelicidade, argumentando a sua demonstração com o verso seguinte:

"Vincit amor patriae laudumque immensa cupido'.»

Mas, num outro passo, as palavras do poeta são desvalorizadas por Agostinho, que classifica a glória historicamente alcançada por Júnio Bruto como «detestanda iniquitas et nihilo utilis reipublicae». A isto chama-se desmontar pela base todo o aparelho da superstrutura dos valores essenciais de uma civilização que não está fundamentada num «ordo rectus», numa hierarquia racional de princípios.

O terceiro aspecto a considerar é que, das 78 vezes em que Agostinho apela para Virgílio, 50\% delas surgem na cidade de Deus. É este um facto significativo, sendo nesta obra que Agostinho empreende a crítica sistemática e fundamentada da cidade pagã ainda muito vigorosa nas tradições e no*s valores que a fundamentavam. Seria interessante fazer a análise de todas as citações desse Virgílio, «hunc Virgilium, [...] quem propterea parvuli legunt, ut videlicet poeta magnus omniumque praeclarissimus atque optimus teneris ebibitus animis non facile oblivione possit aboleri ${ }^{5}$." Mas seria muito longo fazê-lo e afastar-nos-ia do nosso propósito. Registemos, no entanto que a recomendação de Agostinho é que, se não se conseguir extirpar do coração a cupiditas gloriae, pelo menos se lhe anteponha a dilectio iustitiae e o amor veritatis.

Por conseguinte, quando escreve «Fecerunt itaque civitates duas amores duo»" ou "Duas istas civitates faciunt duo amores»", Agostinho não está a usar apenas uma alegoria sem relação concreta com a realidade. Está, pelo contrário, a opor uma sociedade, a velha sociedade com todos os seus amores ou valores, à nova sociedade antevista de longe e cimentada no amor Der: «Ierusalem facit amor Dei; Babyloniam facit amor saeculi»" Cada um tem que analisar com atenção aquilo que ama, para ver de que cidade é cidadão. E, se vir pela análise da qualidade do seu amor que é cidadão dessa Babilónia que é

" «Sai vitorioso o amor da pátria, e o imenso desejo de glória».

${ }^{5}$ De Civit. Dei, PL 4.1, 16: «Este Vergílio [...] que as crianças lêem precisamente para que o grande poeta, o mais ilustre e o melhor de todos, absorvido pelo seu espírito ainda tenro, não possa facilmente ser delido pelo esquecimento."

"De Civit. Dei, PL 411, 436: «Portanto, dois amores construíram duas cidades».

'Ennarrat. in Psalmos, PL 36, 773: «Dois amores constroem essas duas cidades".

"Ennarrat. in Psalmos, PL 36, 773: «O amor de Deus constrói Jerusalém; o amor do mundo constrói Babilónia». 
o mundo presente, com todos os seus valores intactos, então «exstirpet cupiditatem, plantet charitatem»", isto é, substitua a cupiditas, «quia nihil aliud est cupiditas nisi amor rerum transeuntium»".

Com efeito, "si amandus est amor, non utique omnis amandus est»" . Há um amor torpe, feio, que altera a boa ordem, a harmonia do ser, em razão da qual um ser de nível superior não deve deixar-se dominar por outro de nível inferior. E este amor turpis «quo animus se ipso inferiora sectatur» ${ }^{12}$ com mais propriedade se deveria chamar cupiditas.

Neste ponto, o discurso muda de registo ou passa a funcionar em dois registos justapostos, ainda que complementares, deixando de estar objectivado sobre um sistema de valores em concreto, como o que se vira na história de Roma, para se concentrar numa oposição abstracta entre duas forças dentro do homem, coexistentes no mesmo momento e na mesma sociedade. E cito mais uma vez a cidade de Deus: «quapropter quod nunc in civitate Dei, et civitati Dei in hoc saeculo peregrinanti maxime commendatur humilitas, et in eius Rege, qui est Christus, maxime praedicatur; contrariumque huic virtuti elationis vitium, in eius adversario, qui est diabolus, maxime dominari, sacris Litteris edocetur: profecto ista est magna differentia, qua civitas, unde loquimur, utraque discernitur; una scilicet societas piorum hominum, altera impiorum, singula quaeque cum Angelis ad se pertinentibus, in quibus praecessit hac amor Dei, hac amor sui ${ }^{13} . "$

Nos trechos atrás citados, dizia Agostinho que «duas civitates faciunt duo amores.» Mas agora este dualismo amplifica-se, instaurando uma oposição de carácter mais universal entre dois amores antagónicos: «Duo sunt amores,

"Ennarat. in Psalmos, PL 36, 773: «arranque a cupidez, plante a caridade».

${ }^{10}$ De Divers. Quaestionibus, PL 40, 22: «porque a cupidez não é senão o amor das coisas efémeras".

"De Divers. Quaestionibus, PL 40, 23: «se o amor deve ser amado, a verdade é que nem todo o amor deve ser amado".

${ }^{12}$ De Divers. Quaestionibus, PL 40, 23: «pelo qual [o homem] segue coisas inferiores a si próprio".

${ }^{13}$ De Civit. Dei, PL 41, 420. A Cidade de Deus, Tradução, prefácio, nota biográfica e transcrições de J. Dias Pereira, Lisboa, Fundação Calouste Gulbenkian, 1993, vol. II, p.1279: «É por isso que agora, na cidade de Deus e à cidade de Deus, a peregrinar neste século, muito se recomenda a humildade, altamente exaltada no seu rei que é Cristo. Nas Sagradas Escrituras ensina-se que o vício da soberba, contrário a essa virtude, domina sobretudo no seu adversário que é o diabo. Sem dúvida que é grande a diferença que opõe as duas cidades: uma, a sociedade dos homens piedosos, a outra, a dos ímpios, cada uma com os seus anjos próprios em que prevaleceu o amor de Deus ou o amor de si mesmo.» 
mundi et Dei»". E tão antagónicos que "si mundi amor habitet, non est qua intret amor Dei: recedat amor mundi et habitet Dei; melior accipiat locum. Amabas mundum, noli amare mundum: cum exhauseris cor tuum amore terreno, hauries amorem divinum; et incipit habitare iam charitas, de qua nihil mali potest procedere ${ }^{1.5}$. Esta sucessão de antíteses de uma grande simplicidade, mas ao mesmo tempo de uma elegância sugestiva, é completada com a alegoria recorrente em Agostinho da actividade do agricultor, que ora limpa o silvedo, ora semeia e planta o terreno já limpo: «Quasi agrum invenit corda hominum: sed quomodo invenit? Si silvam invenit, exstirpat; si agrum purgatum invenit, plantat. Plantare ibi vult arborem, charitatem. Et quam silvam vult exstirpare? Amorem mundi' ${ }^{16} . "$

Em toda esta oposição - «amor Dei, amor proximi, charitas dicitur: amor mundi, amor huius saeculi cupiditas dicitur» ${ }^{17}$ - não saímos de um registo em que predominam os aspectos ético-religiosos, com alguns afloramentos pela mística. Agostinho, um dos fundadores ou fundamentadores da Idade Média, como foi chamado, teve uma enorme influência em todo o desenvolvimento de uma atitude espiritual e intelectual que passa pelo contemptus mundi, derivada da oposição amor Dei / amor mundi, e que conduziu a uma das mais fecundas formulações da teologia da perfeição e do amor de Deus no séc. XII. Refiro-me à Escola de S. Victor, e, particularmente, a Ricardo de S. Victor, um dos teólogos da experiência de Deus. Tal como Agostinho, Ricardo de S. Victor acentua o papel da inteligência humana num percurso que conduz à compreensão de Deus. Se é impossível, por via da especulação natural demonstrar seja o que o que for a respeito da sua essência, é, no entanto, possível explicitar o conteúdo da revelação cristã e torná-la acessível à

\footnotetext{
"In Epist. Joannis ad Parthos tract. X, PL 35, 1993: «Há dois amores: o do mundo e de Deus".

". In Epist. Joannis ad Parthos tract. X, PL 35, 1993: «Se habitar o amor do mundo, não há por onde entre o amor de Deus: vá-se embora o amor do mundo e habite o amor de Deus. Que o melhor tome o lugar. Amavas o mundo, não ames o mundo. Quando esvaziares o teu coração do amor terreno, absorverás o amor divino; e começará logo a habitar a caridade, da qual nada de mau pode derivar".

"In Epist. Joannis ad Parthos tract. X, PL 35, 1993: «Encontra o coração do homem como se fosse um campo: mas como o encontra? Se encontra um matagal, arranca. Se encontra um campo limpo, planta. Quer aí plantar uma árvore, a caridade. E que matagal quer arrancar? O amor do mundo."

"Ennarrat. in Psalmos, PL 36, 260: «o amor de Deus e o do próximo chamam-se caridade: o amor do mundo, o amor deste mundo chama-se cupidez.»
} 
razão. Com este excurso pretendo exemplificar que em todo o desenvolvimento posterior das linhas de pensamento augustinianas o amor foi o ponto fulcral em que veio assentar uma visão teocêntrica do universo desenvolvida pela reflexão da teologia ocidental. Se da Idade Média passarmos ao Renascimento, encontraremos no humanismo cristão a mesma presença de uma theologia vivificans fundada na profundidade do mistério do amor de Deus entre os homens. No centro dessa teologia, está, tal como em Agostinho, o mistério da Trindade e da essencialidade do amor em toda a criatura, como uma espécie de força seminal que a move para um centro de gravidade que é o próprio Deus. Não se trata de uma imagem abstracta para dar cor a esse impulso vital que parece mover todas as coisas. Mais do que isso, trata-se da natureza intrínseca da criatura, não enquanto emanação de Deus, mas enquanto não-ser que é chamado à existência por uma vontade criadora, em perfeita alteridade e em perfeita gratuitidade de um acto de amor que faz com que o ser seja e permaneça. Assim o diz Santo Agostinho: «Duo quippe sunt propter quae amat Deus creaturam suam; ut sit, et ut maneat. Ut esset ergo quod maneret, Spiritus Dei superferebatur super aquam; ut autem maneret, Vidit Deus quia bonum est. Et quod de luce dictum est, hoc de omnibus. Manent enim quaedam supergressa omnem temporalem volubilitatem in amplissima sanctitate sub Deo; quaedam vero secundum sui temporis modos, dum per decessionem successionemque rerum saeculorum pulchritudo contexitur $^{18}$."

O que subjaz a estas palavras é uma visão grandiosa de um Ser Supremo, que é Supremo Amor, Beleza Suprema e Sumo Bem, que paira sobre o universo como sobre as águas no acto primigénio da criação. E vê que é bom tudo o que cria. E faz com que permaneça. Umas coisas permanecem tendo ultrapassado toda a contingência da temporalidade, na visão da permanência sob a amplíssima santidade de Deus. Outras vivem sujeitas ao tempo constituindo, pela sucessão dos tempos, morrendo e nascendo, nascendo e morrendo, a imensa beleza dos séculos. É de facto grandiosa esta imagem.

\footnotetext{
${ }^{18}$ De Gen. ad litteram, PL 34, 251: «São de facto dois os motivos por que Deus ama a sua criatura: para que seja e para que permaneça. Para que fosse coisa que permanecesse, $o$ Espínito de Deus pairava sobre a água. Para que permanecesse, Deus viu que é bom. E o que foi dito da luz, foi dito de todas as coisas. Permanecem, com efeito, certas coisas que vencem toda a volubilidade temporal na amplíssima santidade sob Deus; outras coisas permanecem segundo a medida da sua duração, enquanto pelo desaparecer e suceder das coisas se entretece a beleza dos séculos.»
} 
Agostinho refere-se, neste contexto, a uma scintilla gratuiti amoris Dei, ou, em expressão reduzida, scintilla boni amoris. É de notar que este termo scintilla vem de Lucrécio e que é utilizado para explicar o que são os semina rerum que constituem a parte activa da matéria. Essa parte activa em Agostinho é a scintilla gratuiti amoris. E por isso exorta: «Si ergo sermo meus invenit in cordibus vestris aliquam scintillam gratuiti amoris Dei, ipsam nutrite: ... dilectione iustitiae, ... amicitia fideli. Hanc scintillam boni amoris flate in vobis, nutrite in vobis: ipsa cum creverit, et flammam dignissimam et amplissimam fecerit, omnium cupiditatum carnalium fena consumit ${ }^{19} . »$

É desnecessário insistir em que as imagens e as palavras de Agostinho têm a sua tradição na literatura clássica pagã. Mas o que as distingue é que falam de outra realidade sem que, no entanto, deixem de evocar os contextos ideológicos em que nasceram. Há neste processo como que uma intenção determinada de substituir as categorias desse mundo pagão pelas categorias da nova doutrina. A visão do mundo muda radicalmente de figura quando se diz que «n baptizatis parvulis, quamvis id nesciant, habitare Spiritum Sanctum»", o qual se identifica com o amor vivo que faz com que o universo seja e permaneça. A criança ignora a sua inteligência, que vai despertando com a idade: «Sic enim eum nesciunt quamvis sit in eis, quemadmodum nesciunt et mentem suam; cuius in eis ratio, qua uti nondum possunt, velut quaedam scintilla sopita est, excitanda aetatis accessu' ${ }^{21} . »$ Mas o apelo a essa força, de ordem profundamente espiritual, faz a diferença em relação aos pressupostos da mundividência pagã, apesar das sublimes elevações da filosofia platónica e estóica.

Agostinho não perde uma oportunidade para reavaliar os pressupostos da mentalidade antiga, sobretudo uma espécie de materialismo ou imanentismo ético, que centra a procura da felicidade na fruição dos bens materiais. Mas o que acontece, diz Agostinho, é que, amando os bens perecíveis e esperando deles a felicidade, acabam por descer da sua condição de seres espiri-

\footnotetext{
1" Sermones de Scripturis, PL 38, 965: «Se, pois, o meu sermão encontrou nos vossos corações alguma centelha do gratuito amor de Deus, alimentai-a: ... com o amor da justiça, ... com a amizade na fé. Soprai em vós a essa centelha do bom amor, alimentai-a em vós. Quando ela crescer e fizer uma chama bem grande e ampla, consumirá a palha de todas as paixões carnais".

* Epistolae, PL 33, 84.1: "nas crianças baptizadas, embora o não saibam, habita o Espírito Santo.»

"Epistolac, PL 33, 841: "Com efeito não o conhecem, embora esteja neles, da mesma maneira que desconhecem a sua mente; neles está adormecida a razào, de que ainda não podem usar, como uma espécie de centelha, a ser espevitada com o desenvolvimento da idade.»
} 
tuais e livres, tornando-se escravos de seres que lhes são inferiores. Esta crítica vem assim formulada no De Vera religione. Agostinho, depois de atacar, o "deterior et inferior cultus simulacrorum, quo phantasmata sua colunt»" voltase para uma tríplice cupiditas ou amor rerum transeuntium: "Serviunt enim cupiditati triplici, vel voluptatis, vel excellentiae, vel spectaculi» ${ }^{23}$. E conclui: «Ita nescientes diligunt temporalia, ut inde beatitudinem exspectent. His autem rebus quibus quisque beatus vult effici, serviat necesse est, velit nolit ${ }^{2 t}$.»

O que Agostinho proclama é, portanto, a libertação das dependências do paganismo. É preciso mudar tudo. E ele sabe o que está a fazer: que a médio ou a longo prazo o seu pensamento, expresso num discurso renovado, com uma retórica límpida que sabe utilizar todos os recursos da exposição clara e da persuasão, irá atrair multidões que se hão-de alimentar das suas ideias e fazer delas um programa de vida, que as hão-de copiar e proclamar do alto do púlpito, modelando pouco a pouco uma sociedade diferente, convidada continuamente a tomar consciência, cada vez mais profundamente assumida, dessa scintilla amoris que é o princípio e o fim de todas as coisas.

As interrogações do Homem continuam a ser as mesmas: mas as soluções apresentadas são diferentes. Agostinho reconhece e declara que para Platão Deus é a origem de todos os seres, da inteligência e do amor com que se vive em bem e felicidade («bene beateque»). Mas a insistência em que se deve usar apenas das coisas temporais, sem fruir delas, para que possamos fruir dos bens eternos, isso é uma resposta que deriva de outros pressupostos. Se a nossa natureza nos pertencesse, e continuo a glosar Agostinho, geraríamos o saber e o amor para atingir a perfeita felicidade, e não precisaríamos de mais nada. Mas porque a nossa natureza tem origem em Deus, dele temos necessidade para que o objecto do nosso saber seja a verdade e a nossa vida a felicidade $\mathrm{e}^{25}$.

Nesta perspectiva teocêntrica, o amor não é mais que uma força que nos atrai para o lugar a que pertencemos. Cada ser tem a sua densidade específica.

\footnotetext{
"De Vera religione, PL 34, 153: "o pior e inferior culto dos ídolos, com que adoram os seus fantasmas."

" De Vera religione, PL 34, 153: "na verdade, servem a uma tríplice cupidez, a da volúpia, a da excelência, a do espectáculo.»

" De Vera religione, PL 34, 153: "Assim, por ignorância: amam as coisas temporais, esperando delas a felicidade. Queira ou não queira, é inevitável que cada um seja escravo daquilo com que pretende ser feliz.»

${ }^{25}$ De Civit Dei, PL 41, 338: «ut vera sapiamus [...] ut beati simus».
} 
Quando se deita azeite e água num recipiente, o azeite apressa-se a vir ao de cima, ocupando cada líquido o lugar que pertence à sua natureza: "ponderibus suis aguntur, loca sua petunt ${ }^{26} .{ }_{.}$Todos vemos que na Natureza as coisas que têm uma estrutura de fraca coesão dos seus elementos são instáveis. E com esta imagem da gravidade e da densidade específica dos corpos Agostinho dá evidência ao seu pensamento: "O nosso repouso é o nosso lugar. Para lá nos eleva o teu amor, e o teu espírito de bondade arranca a nossa baixeza das portas da morte. Na tua boa vontade está a nossa paz. O corpo, com o seu peso, tende para o lugar que lhe é próprio. $O$ peso não tende apenas para baixo, mas para o lugar que lhe é próprio. $\mathrm{O}$ fogo tende para cima, a pedra para baixo. Levados pelos seus pesos, procuram os lugares que lhes são próprios. $\mathrm{O}$ azeite deitado na água sobe ao de cima da água, a água deitada no azeite desce para debaixo do azeite: levados pelos seus pesos, procuram os lugares que lhes são próprios. As coisas menos ordenadas não estão em repouso: ordenam-se e ficam em repouso. $\mathrm{O}$ meu peso é o meu amor; sou levado por ele para onde quer que seja levado ${ }^{27} . »$

Este passo é de uma grande beleza e de uma efusão lírica contida, que explode em frases curtas justapostas, como que em vagas sucessivas num vaivém incessante, acentuado pelo repetição do dímetro sentencioso «Pondus meum, amor meus». O fogo do amor incendeia-nos. Somos levados para as alturas. O fogo do amor torna-nos mais leves e subimos. Se fôssemos animais irracionais, bastava que amássemos a vida carnal, e aí estaria todo o nosso bem. Se fôssemos árvores, sem termos nenhum impulso para o amor, bastarnos-ia essa espécie de desejo ínsito na matéria vegetal, desejo ou determinação genética, que nos levaria a constituir a felicidade na fertilidade dos frutos produzidos. Se fôssemos pedras, e continuo a parafrasear Agostinho, ou vento, ou

\footnotetext{
${ }^{26}$ Confess., PL 32, 848: «Levados pelos seus pesos, procuram os lugares que lhes são próprios.»

${ }^{27}$ Santo Agostinho, Confissões, Tradução e notas de Arnaldo do Espírito Santo, João Beato e Maria Cristina de Castro-Maia de Sousa Pimentel, Centro de Literatura e Cultura Portuguesa e Brasileira, Imprensa Nacional Casa da Moeda, Lisboa, s.d. [2000], livro XIII, IX, 10. Confess., PL, 32, 848: «Requies nostra, locus noster. Amor illuc attollit nos, et Spiritus tuus bonus exaltat humilitatem nostram de portis mortis (Psal. IX, 15) . In bona voluntate pax nobis est (Luc. II, 14) . Corpus pondere suo nititur ad locum suum. Pondus non ad ima tantum est, sed ad locum suum. Ignis sursum tendit, deorsum lapis. Ponderibus suis aguntur, loca sua petunt. Oleum infra aquam fusum, supra aquam attollitur; aqua supra oleum fusa, infra oleum demergitur; ponderibus suis aguntur, loca sua petunt. Minus ordinata, inquieta sunt; ordinantur et quiescunt. Pondus meum amor meus; eo feror quocumque feror."
} 
onda, ou chama, sem sensibilidade e sem vida, não nos faltaria uma espécie de tendência ou força de gravidade para ocupar um lugar na ordem do universo. Enfim, todos os «amores corporum» os arrastam para baixo pela densidade do seu peso, ou para cima pela leveza da sua imaterialidade. Deste modo, em conclusão implícita, "Assim como um corpo é arrastado pelo seu peso, assim o espírito pelo seu amor»" Este passo condensa toda a experiência de Agostinho, já lapidarmente expressa logo no princípio das Confissões e que ele, de certo modo, impôs à posteridade como corolário da condição humana: «tu nos fizeste para ti, e o nosso coração está inquieto enquanto não repousar

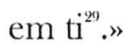

Deste modo, porque somos criaturas espirituais, modeladas à imagem de Deus, verdadeira eternidade, eterna verdade, eterna e verdadeira caridade, eterna, verdadeira e amável Trindade, não devemos deixar-nos arrastar por aquilo que é inferior a nós. Porque todas elas não existiam, ou não teriam ser, se não tivessem sido criadas por aquele que é o Ser Supremo, a Suprema Sabedoria e o Supremo e Sumo Bem. O nosso lugar de repouso, de acordo com a ordem do ser, é aquele em que «esse nostrum non habebit mortem», «nosse nostrum non habebit errorem», «amare nostrum non habebit offensionem»"

Entretanto, a realidade mostra que a vontade é atraída em sentidos opostos, sujeita como está a forças contrárias: o amor saeculi e o amor mundi. $\mathrm{E}$ destas duas forças, aquela que vencer a luta «illuc amantem tamquam pondere trahit»" ${ }^{31}$. Por sua origem e natureza, o peso da alma impele-a para as alturas. Mas há o rerum terrenarum amor que, qual viscum animae, impede o movimento ascensional: «Quod amas in terra, impedimentum est: viscum est pennarum spiritualium, hoc est virtutum, quibus volatur ad Deum. Capi non vis, et viscum amas? $?^{32}{ }$ Esta imagem do visco anda associada à imagem da alma como um ser alado, cujas penas, quando libertas, a elevam para as alturas.

2" De Civit. Dei, PL 4.1, 34.1: «Ita enim corpus pondere, sicut animus amore fertur».

"Santo Agostinho, Confissócs, livro I, I, 1. PL, 32, 659: «quia fecisti nos ad te et inquietum est cor nostrum, donec requiescat in te.»

${ }^{30}$ De Civit. Dei, PL 4.1, 341: «O nosso ser não terá morte», "O nosso conhecer não terá erro", "O nosso amar não terá obstáculo".

${ }^{3}$ Sermones de diversis, PL 39, 1512: "para aí arrasta o amante como que com um peso".

${ }^{32}$ Semones de Sanctis, PL 38, 1: «O que amas na terra é um impedimento: é visco das asas espirituais, isto é das virtudes, com que se voa para Deus. Não queres ser apanhado, e amas o visco?" 
E assim como o amor imundo exerce uma força de atracção para o que é terreno e efémero, precipitando-a no abismo, assim também o amor santo a eleva nas asas do desejo para aquilo que é eterno. Não é da natureza do amor ser inactivo. Se é amor terá que amar: «Necesse est ducat». A nossa obrigação é ver para onde nos conduz: «Habet tamen amor vim suam».

A alma que está enlaçada pelo amor terreno «tem visco nas penas, não pode voar» ${ }^{33}$. E esta imagem termina com um conselho: «O meu conselho não é que não ameis coisa alguma, mas que não ameis o mundo, para amardes livremente aquele que fez o mundo ${ }^{31} . »$ Há um «amor tartareus» ${ }^{35}$ que com o seu visco arrasta para o abismo. Mas há também um amor que tem "penas com que eleva para o céu ${ }^{36}$.

A multiplicidade de aspectos que se ocultam sob a imagem do amor converge num só conceito: que ele é uma força universal que estende o seu império a todo o sistema de valores, no qual se inscreve a experiência do ser humano e a essência da vida em sociedade. Substituindo a noção de amizade, como valor fundamental, pela de amor, Agostinho anuncia o fim do Mundo Antigo e cria os fundamentos de um novo humanismo: pondus meum amor meus.

\footnotetext{
"Ennarat. in Psalmos, PL 37, 1618: "quasi viscum habet in pennis, volare non potest"

"Ennarat. in Psalmos, PL 37, 1618: "Non ergo monemus ut nihil ametis; sed monemus ne mundum ametis, ut eum qui fecit mundum, libere ametis."

${ }^{35}$ Ennarat, in Psalmos, PL 37, 1815.

* Ennarat. in Psalmos, PL 37, 1815.
} 
(Página deixada propositadamente em branco) 


\title{
GLOBALIZAÇÃO E REgIONALISMOS NA EUROPA ROMANA
}

\author{
Jorge de Alarcão
}

(Universidade de Coimbra)

O Império Romano, da muralha de Adriano (na Bretanha) ao limes tripolitano, da Gallaecia à Síria, manifesta uma surpreendente homogeneidade.

Um arqueólogo não pode deixar de observar que a mesma moeda circulava no norte da Bretanha (a Inglaterra dos nossos dias) e no Egipto ou que, numa cidade como Conímbriga, encontramos moedas cunhadas em tão diferentes lugares como Roma, Trier, Nicomédia ou Antioquia. Não pode, também, deixar de se surpreender com a presença de ânforas originárias da Bética na muralha de Adriano ou de outras, produzidas na Lusitânia, em paragens tão distantes como a Palestina. A terra sigillata fabricada no sul da Gália tanto chegava à Lusitânia como à fronteira reno-danubiana ou à África do Norte e a cerâmica chamada Late Roman $C$, produzida no Mediterrâneo Oriental, era utilizada em Bracara Augusta.

Podemos, pois, falar, utilizando uma expressão moderna, de mercado único ou de globalização da economia. Mas, e em primeiro lugar, essa globalização não implica a existência de grandes unidades fabris: no Império Romano, a produção manteve-se ao nível de pequenas oficinas e eram os comerciantes, negotiatores ou mercatores, que garantiam a difusão dos produtos, muitas vezes em navios que fretavam.

Por outro lado, se havia um mercado global de produtos como a terra sigillata ou o vinho, o azeite e o garum que circulavam em ânforas, a cerâmica comum tinha uma difusão mais restrita. Havia, pois, produtos de grande circulação e outros circunscritos a mercados de reduzida área. 
A maior globalização veio, porém, da língua. Na parte oriental do Império, o Grego manteve-se como língua dominante - ainda que, relativamente à Dácia (hoje, Roménia), tenhamos de presumir o predomínio do Latim para explicarmos a integração do romeno no grupo das línguas românicas. $\mathrm{Na}$ Europa Ocidental, porém, até que ponto sobreviveram as línguas faladas antes da ocupação romana? Até que ponto se manteve o bilinguismo?

Esta questão é difícil de resolver. Considerando o caso do português, contém palavras de manifesta origem não-latina que constituem herança da(s) língua(s) falada(s) antes da dominação romana. Muitas delas são topónimos, orónimos ou hidrónimos - e é sabido que estes nomes apresentam considerável permanência. Na época romana foi adorada uma divindade indígena, Reve, que surge com os epítetos (entre outros) de Laraucus e Maranus. Trata-se, certamente, de nomes pré-romanos nos quais se encontra a origem dos nomes actuais das serras do Larouco e do Marão. O nome de Bouro, por alguns filólogos atribuído a um estrato linguístico germânico, é certamente pré-romano, pois já na época romana encontramos uma inscrição consagrada aos Lares Buriei.

Independentemente de nomes geográficos, há, porém, nomes do léxico comum de origem pré-romana. É certo que, para explicá-los, não temos de presumir a manutenção das línguas pré-romanas e o bilinguismo de grande parte da população. A(s) língua(s) falada(s) antes dos Romanos pode(m) ter sido esquecida(s), mantendo-se apenas alguns vocábulos. Mas não podemos deixar de perguntar-nos até que ponto tais línguas podem ter sobrevivido, eventualmente, faladas por gentes que tenham ficado, de certo modo, à margem da romanização.

O habitat normal da população pré-romana do território actualmente português, pelo menos a norte do Douro e em grande parte da zona entre o Douro e o Tejo, era o castro - isto é, o povoado alcandorado em monte e defendido por muralhas. A partir de referências, e particularmente de Díon Cássio, tem-se suposto que os Romanos obrigaram as populações a abandonarem os castros e a fixarem-se em lugares baixos. O achado, em muitos castros, de moedas do séc. IV a.C., conduziu à dedução de que, no Baixo-Império, esses povoados (ou muitos deles) foram reocupados. A verdade, porém, é que não vemos que instabilidade, perigo ou receio possa ter levado, no séc. IV, a um regresso ao habitat castrejo. A argumentação de que as muralhas urbanas construídas nos finais do séc. III ou nos inícios do IV são a demonstração dessa instabilidade não parece inteiramente convincente, até porque podemos 
contrapor o caso das uillae construídas ou reconstruídas na segunda metade do séc. IV - caso que nos faz pensar numa considerável estabilidade e paz, interrompida apenas, no séc. V, pela instalação dos Suevos e o seu cortejo de guerras e saques, documentados por obras literárias como a Crónica de Idácio, bispo de Chaves.

Por outro lado, vão-se acumulando provas arqueológicas de que muitos castros se mantiveram habitados na época romana ou, pelo menos, até finais do séc. I ou inícios do séc. II d.C. É certo que é notória a ausência, nos castros, de materiais reconhecidamente dos séculos II e III, mesmo quando neles encontramos moedas do séc. IV.

O problema é complexo, mas parece-nos que não podemos deixar de considerar a hipótese de uma boa parte da população se ter mantido, ao longo de todo o domínio dos Romanos, em castros longe das vias e dos "benefícios da civilização". A visita que hoje ainda podemos fazer a aldeias perdidas em montanhas (cada vez mais, agora, abandonadas) sugere-nos que, na época romana, podia existir essa mesma profunda distância entre a vida nas cidades ou willae e a vida em remotas aldeias ou castros onde a(s) língua(s) préromana(s) se poderia(m) ter mantido.

Certo é, porém, (e inequívoco) que a língua latina foi um grande factor de uniformização e globalização. E porque é através da língua que, desde a infância, vamos conhecendo e interpretando o mundo e nele nos vamos situando, a adopção da língua latina não pode ter deixado de influenciar e reconfigurar as mentalidades.

Se a difusão de produtos como a terra sigillata ou as ânforas de vinho, azeite ou garum a que inicialmente aludimos são o reflexo da globalização, essa mesma globalização manifesta-se noutros campos como, por exemplo, na arquitectura. A forma clássica do templo tanto se encontra em Ebora (Portugal) como em Camulodum (Inglaterra), Thuburbo Majus (Tunísia) ou Baalbek (Líbano). As termas, não obstante as suas múltiplas formas, obedecem aos mesmos esquemas e às mesmas técnicas construtivas quer se encontram na Lusitânia, na Germânia ou na Dácia. Um romano de Itália não sentiria estranheza de visitar a uilla de Fishbourne (Inglaterra) ou o de S. Cucufate (Portugal).

Não é menos verdade, porém, que na Bretanha, em grande parte da Gália ou na Germânia, encontramos uma forma de templo (dito "céltico" ou "galo-romano") sem paralelo na Itália ou na Península Ibérica ou uma forma 
de uilla ("corridor uilla" dos ingleses) que não encontramos em Portugal. Também é verdade que se adoraram na Lusitânia divindades diferentes daquelas que encontramos na Gália ou na Bretanha.

A divergência dos cultos e das formas de arquitectura religiosa reportam-se, todavia, a um domínio - o da religião - onde as tradições resistem mais à inovação. A religião é, aliás, um dos factores primordiais na constituição das identidades e das diferenças. E, neste domínio, os Romanos manifestaram uma considerável tolerância: nunca pretenderam extirpar os cultos indígenas mas permitiram que as populações continuassem a adorar as suas divindades tradicionais. O politeísmo acomodava facilmente outras divindades no panteão: umas conviviam facilmente com outras.

No domínio da religião são óbvios, pois, os regionalismos. Estes são manifestos também, como dissemos, na arquitectura rural - o que não é difícil de entender se pensarmos quanto as formas de arquitectura doméstica dependem dos materiais regionalmente utilizáveis e do clima.

Mesmo no que concerne à arquitectura pública monumental, muito menos dependente desses factores, podemos encontrar regionalismos, como, por exemplo, capitéis da Líbia romana que utilizam, como elemento decorativo, folhas de papiro (de filiação egípcia) em vez das folhas de acanto normais na arquitectura romana.

Voltando à casa romana, a arquitectura doméstica depende também da composição e dimensão da família. Não temos, no domínio da antropologia social histórica, estudos comparativos que nos permitam abordar a análise da relação entre casa e família nas diversas províncias do Império Romano. Mas, no norte de Portugal e de Espanha, as inscrições funerárias revelam uma realidade social - a gentilitas - de que não encontramos provas óbvias noutras regiões do Império. É incerto, todavia, se esta específica unidade social (cuja natureza e dimensão se não encontram perfeitamente esclarecidas) condicionava a arquitectura doméstica ou apenas as relações sociais e, eventualmente, a organização dos espaços nos povoados e nos seus cemitérios.

Pelo que respeita à Bretanha, certa especificidade das uillae foi já relacionada com a manutenção, na época romana, da família alargada ou coexistência, no mesmo edifício, de dois irmãos ou parentes próximos, com respectivas famílias.

O normativismo - isto é, a ideia de que, numa determinada época, todos se regiam pelos mesmos padrões ou normas - é um perigo de que nós, 
arqueólogos, nos devemos defender. A multiplicidade dos padrões é um índice das sociedades complexas - e a sociedade romana era manifestamente complexa. A classificação da sociedade romana como esclavagista parece-nos, por exemplo, duvidosa. Não contestamos a existência de escravos e até de escravos em grande número. Mas não podemos deixar de nos perguntar se, em toda a parte, o trabalho rural ou artesanal, na época romana, assentava na escravatura. No que diz respeito ao território actualmente português, a existência do latifundium, mesmo no Alentejo, é mais que duvidosa. Grande parte da população vivia, não em cidades ou uillae, mas em aldeias e em pequenas ou médias propriedades rústicas para as quais temos vindo a propor os nomes de casais e granjas. O casal era uma pequena unidade de produção unifamiliar. Imaginamos livres os habitantes de um casal. A granja era uma propriedade maior que implicava já a existência de criados de lavoura. Mas também nos perguntamos se tais criados seriam, na maioria, escravos ou assalariados de condição livre.

O mundo romano era extremamente complexo. A distância social entre honestiores ou clarissimi uiri, por um lado, e camponeses, por outro, era muito grande. Muito diferente era também a vida numa grande cidade como Augusta Emerita ou Olisipo ou numa pequena aldeia da região que é hoje a nossa província de Trás-os-Montes. O entrecruzamento dos mais diversos factores - étnicos, económicos, sociais, políticos, culturais, sem esquecer as tradições diversas dos múltiplos povos que foram integrados no Império Romano - conduziu a uma diversidade que nós, arqueólogos ou historiadores do mundo antigo, temos muitas vezes esquecido, quer porque nós representamos o mundo romano a partir de textos literários, quer porque sobrevalorizamos esses itens de cultura material como terra sigillata e ânforas que se encontram difundidas por vastas áreas. Mas, como tem sido salientado, a arqueologia permite conhecer o que os textos literários não dizem. $\mathrm{E}$ textos como os de Estrabão e Plínio não são, afinal, excelente ilustração da diversidade que existia no Império?

O título da nossa comunicação - Globalização e regionalismos - pode sugerir que o Império Romano era um todo composto de partes com identidade própria. Isso é, até certo ponto, verdade. Mas as partes não coincidem com as fronteiras político-administrativas das províncias e mesmo no interior de cada parte havia diversidade e complexidade. 
As estruturas organizadas - quer as político-administrativas provinciais ou locais, quer as económicas dos grandes negotiatores - não estruturaram senão os níveis superficiais da sociedade, isto é, não alteraram senão o que era necessário que fosse alterado para garantir a paz e a coesão político-social (e, para os negotiatores, os seus interesses económicos). Tomando o caso do Direito, considerado (e justamente) como uma das grandes realizações do génio romano, o corpo de leis codificadas não suprimiu múltiplas regras e práticas jurídicas das quais, infelizmente, não temos conhecimento directo porque não foram escritas e codificadas pela jurisprudência romana. Trata-se, no fundo, do problema do alcance, em profundidade, das ńormas que o poder estabeleceu - ou da coexistência, pacífica, de normas universais com outras normas, locais ou religiosas, que, a um nível mais profundo - o da vida política ou quotidiana - estruturavam a sociedade. A um nível macro-político, macro-social ou macro-económico, podemos falar de globalização; mas, a um nível micro-social, mantiveram-se diferenças e especificidades que não conduziram, todavia, a disfuncionamentos ou tensões. O Império Romano representa uma notável unificação da pluralidade e realizou a coesão do diverso. 
(Página deixada propositadamente em branco) 


\section{Série}

\section{Documentos}

Imprensa da Universidade de Coimbra

Coimbra University Press

2005

- U

C - 